\title{
Contemporary Sediment Delivery Ratios for Small Catchments Subject to Shallow Rainfall Triggered Earthflows in the Waipaoa Catchment, North Island, New Zealand.
}

Katie Elizabeth Jones

A thesis submitted as partial fulfilment of the requirements for the degree of Master of Science with Honours in Physical Geography

School of Geography, Environment and Earth Sciences Victoria University of Wellington

September 2009 


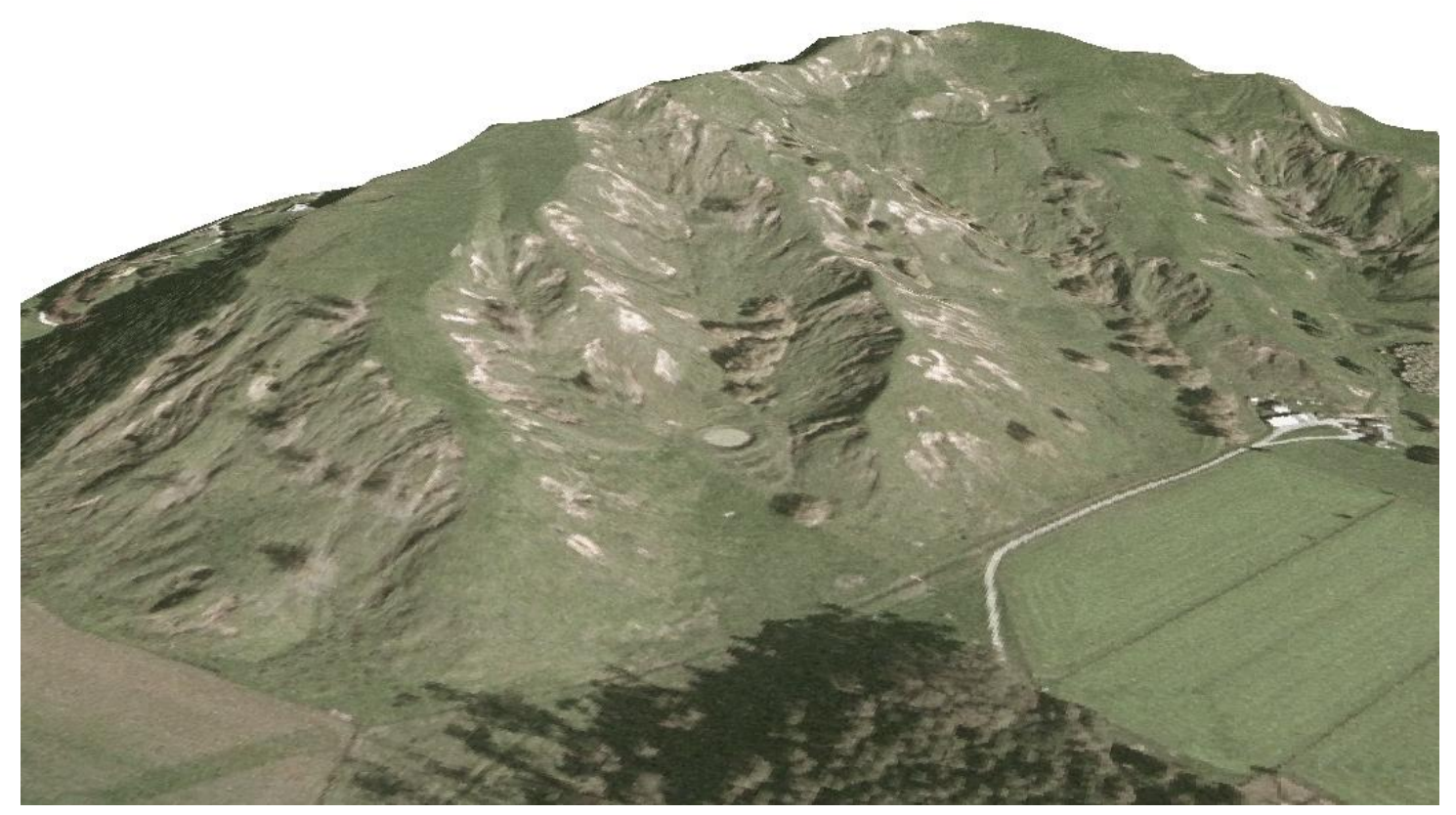

DEM of the Hinenui Catchment overlain with 2007 aerial photo 
The Waipaoa catchment is generally considered to have high hill slope channel coupling due to the large volumes of sediment output at the river mouth. Yet the percentage of sediment that is transported within the fluvial system is low when considered in terms of the total volume of sediment mobilised during episodic failure events. Clearly, there is a discrepancy between generation of sediment and its delivery to the fluvial network. Previous research has suggested there is a strong decrease in catchment connectivity as catchment size increases. However, little research has been undertaken to understand the changes in hillslope-channel coupling over time.

This study focuses on the connectivity of shallow rainfall triggered earthflows located in small catchments located within three different land systems in the Waipaoa Catchment. A multiple regression model was developed to predict the sediment delivery ratio for individual earthflows based on an empirical dataset of earthflows which occurred during a storm event in 2002. The results from this modelling were applied to five larger sub-catchments where sequential aerial photograph analysis (1940s to 2004) was used to determine connectivity. From this, spatial and temporal patterns in the catchment sediment delivery ratios were identified.

The expected decrease in sediment delivery ratios was observed as catchment size increased. However, the temporal pattern to sediment delivery is not so clear. It appears that catchment evolution, referring specially to the Terrain Event Resistance Model developed by Crozier and Preston (1999), does not have a significant influence on sediment delivery ratios within the six decades examined in this thesis. Furthermore, while earthflows are considered the ultimate source of sediment during storm events, they are not always the mechanism by which this sediment enters the fluvial network. It is also vital to consider rates of gullying, sheet erosion and riparian erosion. 


\section{Acknowledgements}

This project was made possible by funding from the PGSF Terrestrial Landscape Change: MARGINS Source-to-Sink New Zealand Programme (Contract No. COX0705). At GNS Science I would like to thank Mike Page, Dr. Noel Trustrum and Dr. Nicola Litchfield who provided guidance within this programme.

Further support was provided with the Murray King Memorial Scholarship through the Greater Wellington Regional Council.

Thank you to Dr Nick Preston (Supervisor) for his patience, advice, encouragement and guidance throughout this thesis. At Victoria University I would also like to thank Dr Mike Crozier for always being willing to answer questions about landslides. Andrew Rae for always being willing to help with endless GIS questions, Mark Henderson for creating the Hinenui DEM and also Erin Baylis for helping with field work. To my co-workers David Olson and Helene Marsters a very special thanks for their companionship and laughs throughout the writing of this thesis.

I would also like to thank Dr Basil Gomez from Indiana State University for his generous guidance and encouragement.

I am extremely grateful to the landowners of the field site Hinenui, Brett and Lucy Teutenberg for allowing me onto their land.

Thank you to Mark Cockburn and Greg Hall at Gisborne District Council.

To my Family, I would like to thank you for your continued love and endless support throughout writing this Thesis. 


\section{Table of Contents}

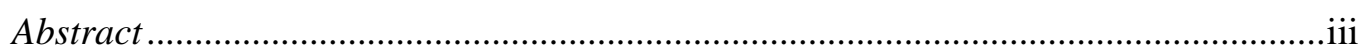

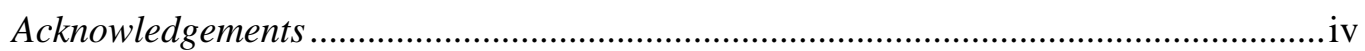

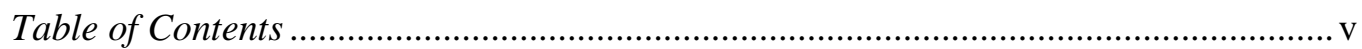

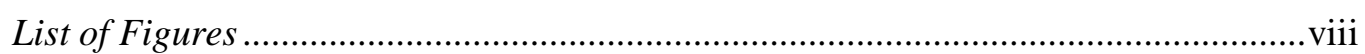

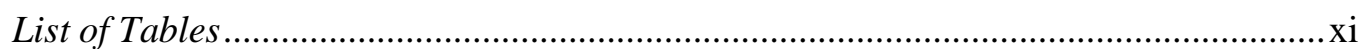

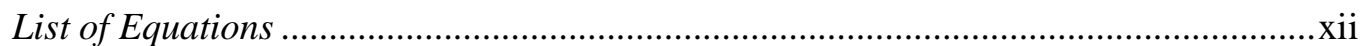

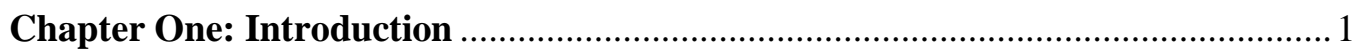

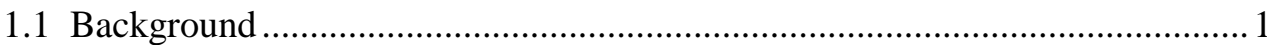

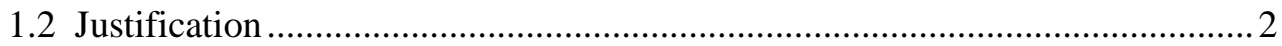

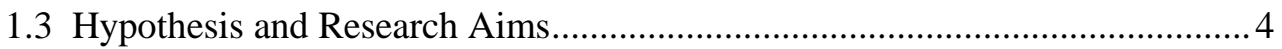

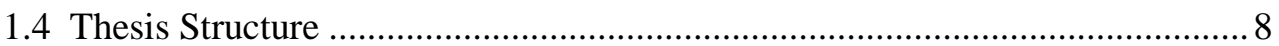

Chapter Two: Landslides and Sediment Delivery ……........................................ 10

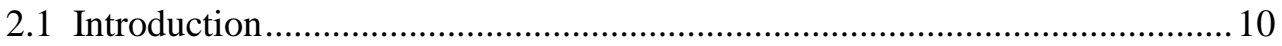

2.2 The Concept of Sediment Delivery ................................................................. 11

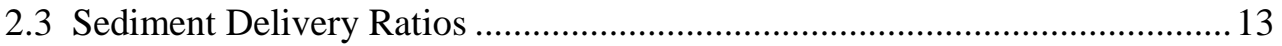

2.4 Landslides and Sediment Delivery …………............................................... 16

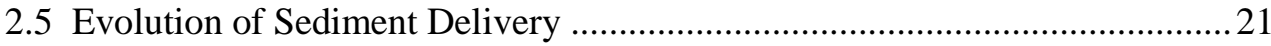

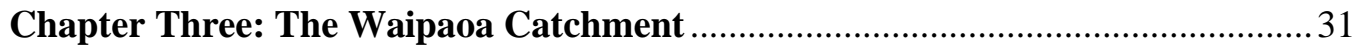

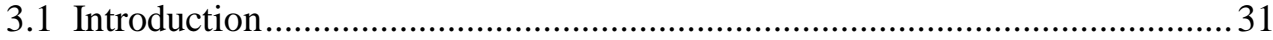

3.2 Geological Setting and Geomorphic Processes............................................... 33

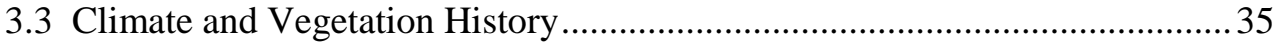

3.4 Land Systems Classification ........................................................................... 37

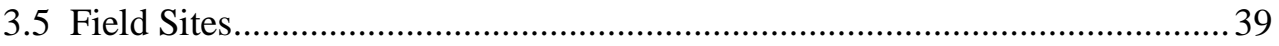

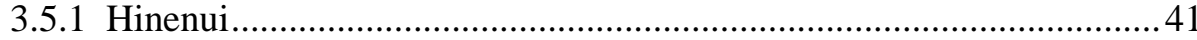

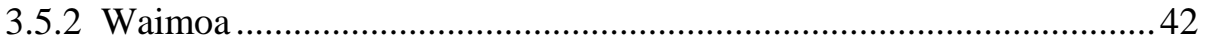

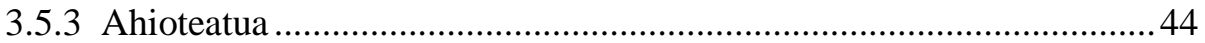

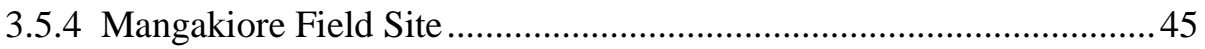




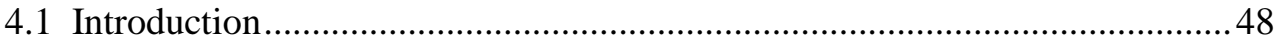

4.2 Sediment Delivery Ratio Multiple Regression ………..................................50

4.2.1 Morphometic and Landslide Properties ..............................................50

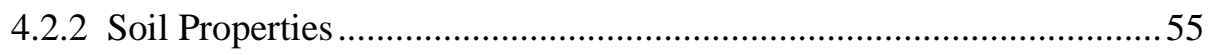

4.2.3 Multiple Regression Analysis .........................................................56

4.3 Spatial and Temporal Trends in Sediment Delivery ……….............................57

4.3.1 Mapping Landslides and Channel Density .........................................57

4.3.2 Connectivity and Sediment Delivery Ratios ..........................................6 66

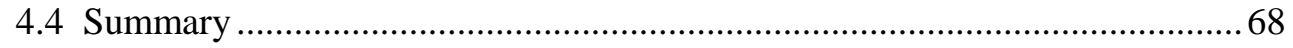

Chapter Five: Spatial and Temporal Patterns of Sediment Delivery Ratios..........69

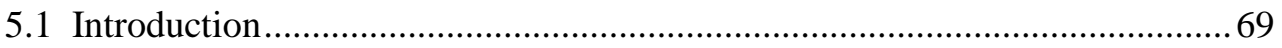

5.2 Multiple Regression Analysis of the Hinenui Earthflows................................ 69

5.2.1 Analysis of Multiple Variables ............................................................ 69

5.2.2 Multiple Regression Analysis of Sediment Delivery ........................... 72

5.2.3 Multiple Regression Analysis of Runout Modelling............................ 72

5.2.4 Multiple Regression Analysis of Scar Length Modelling .................... 74

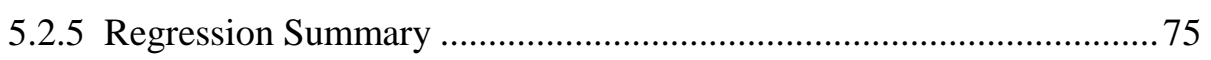

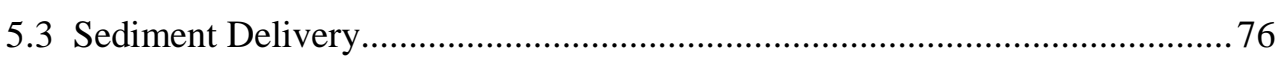

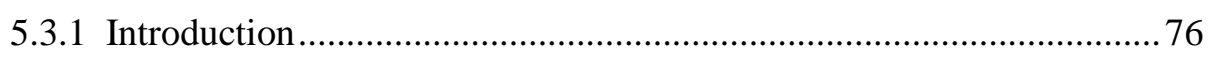

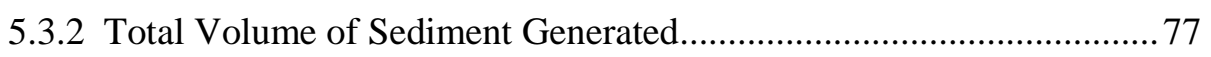

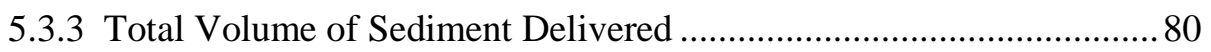

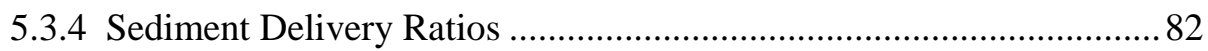

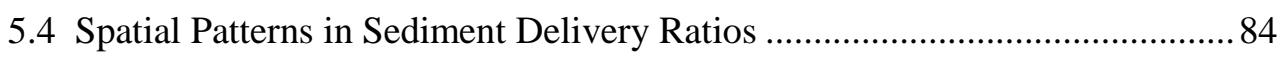

5.5 Temporal Patterns in Sediment Delivery Ratios ............................................... 87

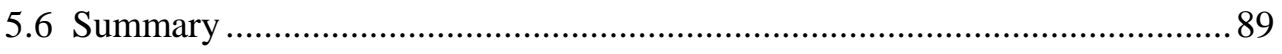


Chapter Six: Evolution of Sediment Delivery and its Implications for Determining

Ratios in the Waipaoa Catchment ................................................. 90

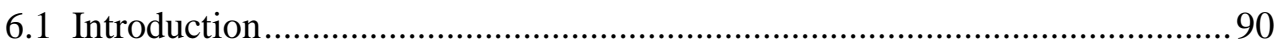

6.2 Limitations of the Ability to Predict Sediment Delivery ................................ 90

6.3 The Importance of Scar Distance from the Channel ........................................ 92

6.4 Changes in Sediment Delivery over Time ……….......................................... 94

6.4.1 Landslide location and Upslope Migration ..........................................95

6.4.2 Trajectories of Catchment Evolution ................................................... 97

6.5 Time Independent Sediment Delivery Ratios ................................................. 100

6.5.1 Validation of the Sediment Delivery Ratios ...................................... 104

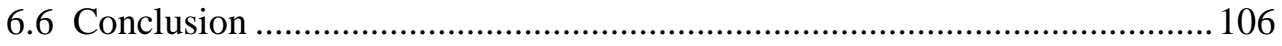

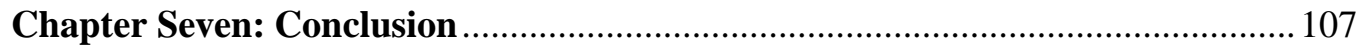

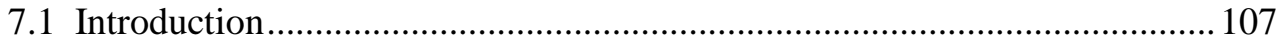

7.2 Deriving Off-Slope Delivery Ratios ............................................................. 107

7.3 Application of Predictable Patterns in Catchment Sediment Delivery Ratios .... 108

7.4 Recommendations for Future Research 110

References.

Appendices 120

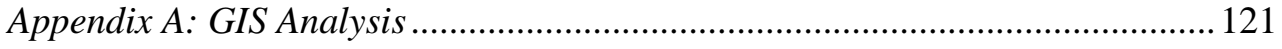

Appendix B: Multiple Regression Analysis ........................................................ 129

Appendix C: Sediment Delivery Ratios ............................................................. 140

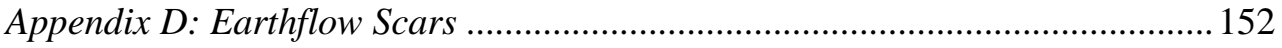

Appendix E: Storm History of the Waipaoa Catchment........................................ 171 


\section{List of Figures}

Figure 1.1 Predicted changes in sediment delivery ratios at different spatial and temporal scales

Figure 2.1 Relationship between sediment delivery ratio and the drainage basin area

Figure 2.2 Lateral spread of the debris tail runout from an earthflow scar in the Coromandel, New Zealand

Figure 2.3 Extensive landsliding in the Hawke's Bay region, New Zealand, resulting from Cyclone Bola

Figure 2.4 Historical and simulation models for failures on the Wairarapa hillslopes, New Zealand

Figure 2.5 Terrain Event Resistance Model

Figure 2.6 Average percentage ground uneroded since deforestation of the slopes. Standard deviation derived from 100 simulation runs is also shown

Figure 2.7 Changes in the location of landslide scars due to regolith exhaustion 28

Figure 3.1 A) Location of the Waipaoa Catchment in the East Cape region of the North Island of New Zealand. B) The main tributaries to the Waipaoa River in the Waipaoa Catchment

Figure 3.2 The location of the three field sites (Waimoa, Ahioteatua and Mangakiore) used in this thesis to identify spatial and temporal trends in sediment delivery ratios for earthflows

Figure 3.3 The Hinenui Catchment after the 2002 storm event 42

Figure 3.4 Topographic map of the Waimoa Catchment 43

Figure 3.5 Topogaphic map of the Ahioteatua Catchments 45

Figure 3.6 Topographic map of the Mangakiore Catchments 47 
Figure 4.1 Flow diagrams of the methodology of this thesis and also an overview of the structure of this chapter

Figure 4.2 A) S6 stations in the Hinenui catchment. B) S6 in use by M. Henderson scanning the Hinenui catchment

Figure 4.3 Evidence of channel formation at the top of the Hinenui catchment

Figure 4.4 Soil sample locations in the Hinenui

Figure 4.5 Misalignment of catchment boundaries and channels as digitised from images of the three field sites

Figure 4.6 Nested catchments within the three field sites 62

Figure 4.7 Sources of error when deriving connectivity from buffered layers 67

Figure 5.1 Plot of the fitted model developed to predict earthflow runout length (Lr) with the change of elevation between the start and end of the runout path (Er) and slope of the runout path $(\mathrm{Sr})$

Figure 5.2 Plot of the fitted model developed to predict scar length (Ls) using the independent variable scar volume (Vs)

Figure 5.3 Spatial patterns to sediment delivery ratios in Waimoa catchment A 85

Figure 5.4 Spatial patterns to sediment delivery ratios in Ahioteatua catchment A 85

Figure 5.5 Spatial patterns to sediment delivery ratios in Ahioteatua catchment B 86

Figure 5.6 Spatial patterns to sediment delivery ratios in Mangkiore catchment A 86

Figure 5.7 Spatial patterns to sediment delivery ratios in Mangakiore catchment B 86

Figure 5.8 Temporal patterns in sediment delivery ratios for Waimoa catchment A 87

Figure 5.9 Temporal patterns in sediment delivery ratios for Ahioteatua catchment A .... 88

Figure 5.10 Temporal patterns in sediment delivery ratios for Ahioteatua 88

Figure 5.11 Temporal patterns in sediment delivery ratios for Mangakiore catchment A ... 88

Figure 5.12 Temporal patterns in sediment delivery ratios for Mangakiore catchment B .. 89 
Figure 6.1 Differences in debris flows from Hinenui earthflows triggered in the 2002 storm event

Figure 6.2 Changes in the location of earthflow scars in relation to the fluvial network for each aerial photo in the Waimoa Catchment

Figure 6.3 Changes in the location of the observed earthflow scars in relation to the fluvial network for each aerial photo in Ahioteatua Catchment A

Figure 6.4 Changes in the location of the observed earthflow scars in relation to the fluvial network for each aerial photo in Ahioteatua Catchment B 93

Figure 6.5 Changes in the location of the observed earthflow scars in relation to the fluvial network for each aerial photo in Mangakiore Catchment A

Figure 6.6 Changes in the location of the observed earthflow scars in relation to the fluvial network for each aerial photo in Ahioteatua Catchment B

Figure 6.7 Evolutionary model of terrain resistance following deforestation 99

Figure 6.8 Sediment Delivery Ratio determined from catchment size 101

Figure 6.9 Sediment delivery ratios for the Wharekopae land system

Figure 6.10 Sediment delivery ratios for the Waihora land system

Figure 6.11 Sediment delivery ratios for the Te Arai land system

Figure 6.12 Cumulative percentage of the earthflow scars in relation to distance from the fluvial network for the five field sites representing the Wharekope (Waimoa catchment), Waihora (Ahioteatua catchments) and Te Arai (Mangakiore catchments) land systems .. 103

Figure 6.13 Sediment slug infilling the Hinenui valley 105 


\section{List of Tables}

Table 2.1 Examples of proposed relationships between sediment delivery ratio and catchment characteristics

Table 3.1 Summary of the six landslide prone land systems in the Waipaoa Catchment

Table 4.1 Aerial photography for the three field sites of Waimoa, Ahioteatua, and Mangakiore

Table 5.1 Summary of the frequency distribution statistics for the variables used on this study for 71 earthflows and the debris tail runout paths

Table 5.2 Pearson product moment correlations between the variables used for the regression analysis at Hinenui for the 71 earthflows and the debris tail runout paths.

Table 5.3 Total Volume of sediment generated in the Waimoa, Ahioteatua and Mangakiore Catchments from earthflows for each nested catchment

Table 5.4 Total volume of sediment delivered to the fluvial network in the Waimoa, Ahioteatua and Mangakiore Catchments from earthflows for each nested catchment

Table 5.5 Sediment Delivery Ratios for each nested catchment within the Waimoa, Ahioteatua and Mangakiore Catchments 


\section{List of Equations}

Equation 4.1 Sediment Delivered to the Fluvial Network …......................................... 68

Equation 4.2 Catchment Sediment Delivery Ratio ..................................................... 68

Equation 5.1 Sediment Delivery Ratio ………….................................................... 72

Equation 5.2 Earthflow Debris Tail Runout Distance .................................................. 73

Equation 5.3 Earthflow Scar Length ..................................................................... 74 


\section{Chapter One: Introduction}

\subsection{Background}

As a predominantly agricultural society, New Zealand is acutely sensitive to landscape changes. The landscape is still young in geological time scales and denudation rates are high, leaving highly dissected landforms. This natural rate of erosion has been amplified by human modification of the landscape primarily due to mass clearance of indigenous forest for conversion to pasture by European settlers in the late $19^{\text {th }}$ and early $20^{\text {th }}$ Centuries. The removal of this indigenous vegetation cover has in many places lowered erosion thresholds resulting in higher rates of regolith stripping. The continued depletion of the soil resources due to amplified erosion processes, particularly in hill country catchments, has resulted in a reduction of the production potential of the landscape which cannot be reclaimed in the short term (Trustrum et al., 1984). The economic cost of this soil erosion is estimated to be $\$ 127$ million/year and increasing (Krausse et al., 2001). Nevertheless, better management of these erosion prone landscapes can reduce disruptions and minimise their impact. To successfully reduce the response there needs to be a better understanding of the controls on landscape behaviour especially with the potential increase in extreme weather events, which are often triggers in initiating erosion processes. By understanding these processes which generate sediment and the complex conveyor belts that this sediment is transported on, more effective land use practices can be implemented.

However, the source to sink sediment progression is not a straightforward process. Various landforms can disrupt longitudinal, lateral and vertical linkages either temporarily or enduringly, storing sediment or discharging stored sediment thereby influencing sediment cascades. This distribution of sediment stores reflects and influences the routes, timing and distances of sediment transport providing a measure of the (dis)connectivity of the catchment. This also impacts the response from adjustments within the landscape system and how major, minor, gradual or sudden perturbations are propagated throughout the environment. Fryirs et al. (2007, pg. 49) state "Catchment 
configuration and the nature of connectivity within and between landscape compartments affect the operation of sediment cascades and geomorphic responses to disturbance events of differing magnitude and frequency" (p. 49). Thus, understanding and characterising landscape response requires the consideration of the whole connectivity of the source to sink system defined as the transfer of energy and matter between two landscape compartments or within a system as a whole (Chorley and Kennedy, 1971).

Therefore, to better manage the landscape an improved knowledge of both the way landscapes behave and the controls on this behaviour is required, with awareness of the spatial and temporal patterns of sediment generation, transport and storage within a catchment. Sediment flow diagrams and budgets are often used to display the relationships between sediment inputs, outputs and storage within catchments and in particular source to sink sediment cascades (e.g. Selby, 1993). The position, effectiveness and configuration of sediment storage units in the catchment are represented by constrictions on these flow diagrams. Furthermore, these natural obstructions dictate how the effects of geomorphic changes are propagated through a catchment. Nevertheless, the nature of these constrictions is not clear. There is the need to understand each separate system within the catchment as a whole and the interactions between these systems. From this, cause and effect relationships from landscape disturbance can be clearly defined. Prospective impacts of landscape disturbance, whether natural or induced, can then be projected across the entire source to sink system and numerical modelling can be used to explore the possible future trajectories within the system.

\subsection{Justification}

The concept of landscape evolution and landform processes is well researched within geomorphology and in particular the process, cause and consequences of slope failure. There is competent understanding of mechanics of the specific processes and the conditions that predispose slopes to failure allowing for the identification of areas at risk 
of failure due to natural processes and often artificial alteration (Varnes, 1978; Crozier, 1986; Dikau et al., 1996). This has evolved into research on frequency magnitude relationships of erosion processes and the concept of thresholds and event resistance (Crozier and Preston, 1999; Hicks et al., 2000; Reid and Page, 2002). As a consequence, there is admirable understanding of how, where and when erosion occurs. Yet predications of slope failure are only accurate on a broad scale. In spite of this, there is limited understanding of the off slope delivery of this sediment after the initial failure. Will the failed regolith from a landslide be deposited on the slope or will it be entrained into the fluvial network? There is currently a significant amount of research into the ability to predict sediment generation and delivery for various erosional processes to determine the contribution to the overall sediment yield (Trustrum et al., 1999; Page et al., 1999; Lu et al., 2006). Nonetheless, there is limited information on how this behaviour changes through time. Litchfield et al., (2008, pg. 413) state "to evaluate the contribution of long-term hillslope processes the amount of sediment being transferred from the hillslopes to the channels needs to be estimated, as does the timeframes over which this occurs. The delivery of sediment from gully erosion has been quantified, but only limited knowledge has been gained about the delivery from other processes such as shallow and large landsliding. "

This thesis will assist in determining the contribution shallow earthflows make to a sediment budget across a large scale catchment at various scales. It will do this by determining connectivity and predicting sediment delivery ratios for earthflows triggered by heavy rainfall events. This research will focus on identifying changes in hillslope channel coupling and in particular spatial and temporal patterns in sediment delivery ratios. The study area selected for this is the Waipaoa catchment located in the East Cape of the North Island of New Zealand. The Waipaoa basin provides an ideal environment to study the evolution of sediment delivery from earthflows. The catchment has undergone significant land use changes, firstly with Polynesian settlement and then, more significantly, European settlement. This, combined with highly erodible geology, means the Waipaoa catchment has one of the highest specific sediment yields in the world (Hicks et al., 1996). Here, deep seated landslides and 
amphitheatre gully complexes are common erosional features which deliver large pulses of sediment to the fluvial system (Trustrum et al., 1999). In addition, low magnitude high frequency rainfall events which trigger gully and sheet erosion provide regular contributions of sediment (Page et al., 1999). However, shallow earthflows account for a significant portion of the sediment budget within the Waipaoa catchment during storm events (Page et al., 1999). Therefore, it is important to understand the controls on the spatial and temporal behaviour of the delivery associated with these earthflows.

\subsection{Hypothesis and Research Aims}

This thesis endeavours to identify sediment delivery ratios (the amount of sediment delivered off slope as a proportion of the total sediment generated in a given erosional event) for shallow earthflows triggered by heavy rainfall events. The overall focus for this research is to provide a range of ratios that represent the characteristic off-slope sediment delivery to the fluvial network for earthflows in the Waipaoa catchment. The delivery ratios will be across a series of landscape conditions at varying spatial and temporal scales. These individual ratios will aid the understanding of the source to sink processes within the Waipaoa Catchment where the Terrestrial Landscape Change: MARGINS Source-to-Sink New Zealand Programme is modelling the evolutionary behaviour of this catchment. 
The hypothesis introduced for this thesis is given below:

The overall average sediment delivery ratio for a catchment will decrease in both space and time as the catchment evolves with increasing time since deforestation resulting from changes in the spatial distribution of erosion (Figure $1.1 A \& B$ ).

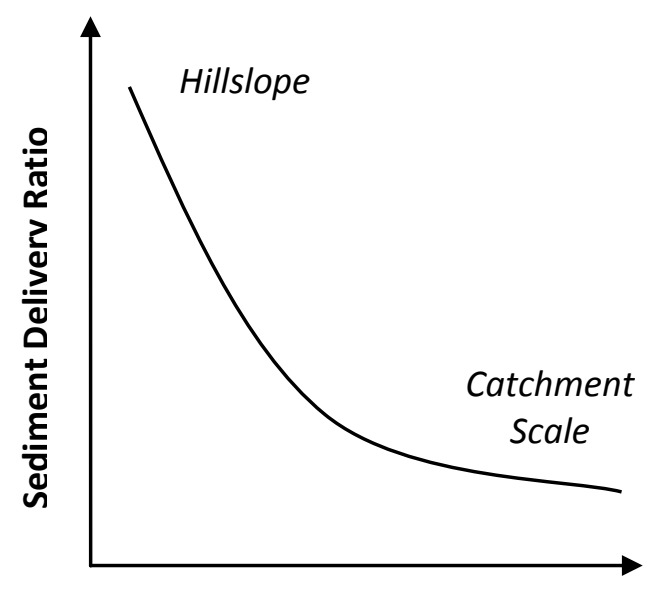

A. Relative Area

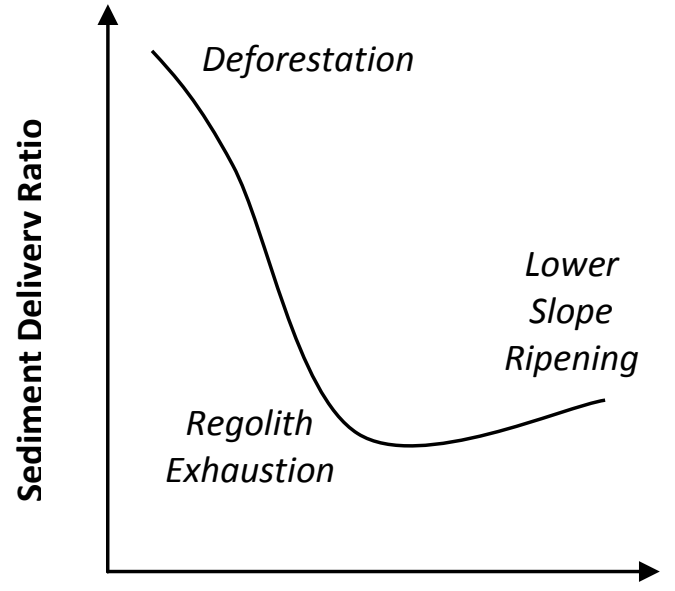

B. Relative Time

Figure 1.1 Predicted changes in sediment delivery ratios at different spatial and temporal scales. A) At the individual to hillslope scale sediment delivery ratios can be very high, but in larger catchments the potential for storage before delivery increases. Therefore sediment delivery ratios will be relatively low in a large catchment. B) The response to land use change results in a lowering of sediment delivery as the systems moves towards a regolith exhaustion phase with landslides moving upslope and away from the channels. Eventually there is ripening of the lower slopes made up redeposited material which becomes prone to failure raising the overall sediment delivery ratio.

This hypothesis refers to the changes in landslide location over time as a direct result of catchment evolution since land use change (Crozier and Preston, 1999; Brooks et al., 2002). Scar retreat upslope is an important factor where scar crowns are likely to be reactivated in the next triggering event but this failure is further from the channel than the 
initial failure. Because of this landslide derived sediment will have to travel further down slope for off-slope delivery to the fluvial network. In addition, if sediment delivery is not $100 \%$ for landslides, then the remaining material is left on the slope creating a barrier for sediment delivery by increasing slope roughness and decreasing slope angle. This potential for barrier and buffers preventing sediment delivery is increased with catchment size as there is greater storage potential in larger catchments. And since subsequent failures will be located above current scars in the remaining regolith again, meaning the new scars are further from the channel network, the ability for the landslide debris tail to intercept a channel is reduced by each failure event.

To test the above hypothesis for sediment delivery ratios of shallow landslides within the Waipaoa catchment three aims are introduced:

1. Develop a multiple regression equation to predict sediment delivery ratios associated with individual failures (and thus enabling summation to derive an overall sediment delivery ratio for a small sub-catchment) based on simple predictive variables.

This first aim refers to the development of a simple multiple regression equation used to determine the off-slope delivery for a single earthflow to the adjacent (ephemeral or permanent) channel. From this the sediment delivery ratio for an entire hillslope and small catchment can also be predicted. While hillslope channel connectivity (a measure of the coupling between the hillslope and channel network) may be high it does not necessarily equate to high sediment delivery ratios. The development of a regression model to predict sediment delivery ratios enables more accurate estimation of off-slope delivery than using a constant ratio across an entire large scale catchment (e.g. Page et al., 1999). Distance from the earthflow scar to the initial fluvial channel is put forward as the primary controlling factor. Relief and failure properties are theorised as secondary controlling factors. 
2. Determine the connectivity and sediment delivery ratios associated with shallow rainfall triggered landslides for a range of catchment sizes within three landslide prone land systems in the Waipaoa catchment to identify patterns in hillslope channel coupling directly related to catchment size.

The second aim endeavours to display how sediment delivery ratios for catchments vary in space. Connectivity is an easily derived variable, for both a single failure to basin scale. For a single failure, it is simply defined as the presence of coupling between the hillslope and channel network, i.e. whether or not a landslide debris tail actually reaches a channel. The number of failures that are connected when expressed as a proportion of the total failures gives a measure of a catchment's connectivity. Sediment delivery ratios are more complex. The sediment delivery ratio from a single earthflow is determined by various factors and therefore can be any number from $0 \%$ to $100 \%$. The first aim addresses this issue, seeking an objective basis on which to estimate an appropriate value of delivery for individual failures. Because only a percentage of earthflows will be connected to a channel (ephemeral or permanent) resulting in offslope delivery to the fluvial network, estimation of catchment sediment delivery ratios must be based on connectivity. The objective of this second aim is to illustrate the lowering of sediment delivery ratios for shallow earthflows as catchment size increases for the Waipaoa catchment.

3. Define the connectivity and sediment delivery ratios associated with shallow rainfall triggered landslides for a range of temporal scales within the Waipaoa catchment to identify patterns in sediment delivery ratios related to catchment evolution following change in boundary conditions.

The third aim investigates how connectivity and sediment delivery ratios for a catchment vary on a temporal scale. Again, while connectivity is easily derived the objective is to identify a range of sediment delivery ratios which take into account the stages of landscape relaxation of the Waipaoa catchment from the mid $20^{\text {th }}$ Century, following a major environmental change that took place in the late $19^{\text {th }}$ Century through 
to the early $20^{\text {th }}$ Century. Hillslope channel coupling is strongly influenced by the evolutionary stage of the catchment the sediment delivery ratios are affected by relaxation within the catchment. This concept is often not considered when modelling sediment delivery ratios as it is not well constrained.

\subsection{Thesis Structure}

This thesis is divided into seven chapters which present the research and results for this study. The content of these chapters is summarised below:

Chapter One: Provides the background and justification for this research along with the specific aims and hypothesis for this thesis.

Chapter Two: Discussion of the literature to date that has been undertaken to understand and determine both sediment delivery ratios and the contribution of landslides to the overall sediment budget of a large catchment.

Chapter Three: Introduces the study area and the particular sub-catchments used in this research. It gives an overview of both the physical processes and cultural history of the area and their effects on the erosion currently experienced.

Chapter Four: Presentation of the overall methodology and techniques of data collection and analysis to model off slope sediment delivery ratios for individual earthflows and determine catchment delivery ratios.

Chapter Five: Display of the results obtained from the above methodology to determine the catchment sediment delivery ratios. Results of the regression analysis for modelling sediment delivery ratios are presented in this chapter followed by the spatial and temporal trends of sediment delivery as the Waipaoa catchment evolves since deforestation. 
Chapter Six: Discussions of the spatial and temporal patterns displayed in the previous chapter. Cause and effect concepts for these trends are also discussed in an endeavour to discover and isolate the factors that control sediment delivery ratios for earthflows.

Chapter Seven: Presents the conclusions and summaries derived from this research. 


\section{Chapter Two: Landslides and Sediment Delivery}

\subsection{Introduction}

The transfer of sediment from source to sink can be viewed at a variety of temporal and spatial scales, depending on the processes to be studied and the approach adopted. The attempts to account for the different components of sediment flux are often framed in terms of a sediment budget (e.g. Dietrich et al., 1982). Irrespective of scale, one of the most challenging and difficult problems to resolve revolves around the issue of how much of the sediment produced on hillslopes enters the channel network and is discharged at the basin outlet for a given time period. This can be the catchments response to a single storm event or the longer scale of geologic time. Viewed from the perspective of measurements of (suspended) sediment discharge, which are routinely made in many drainage basins, the pertinent question is: what is the relationship between the sediment yield at the measuring point (Y) and the total amount of sediment eroded from the basin upstream of that point (T)? Roehl (1962) termed this relationship the 'sediment delivery ratio', $\mathrm{D}$ (where $\mathrm{D}=\mathrm{Y} / \mathrm{T}$ and is often expressed as a percentage).

This chapter reviews research on sediment generation, storage, and transfer within fluvial systems, providing a background to the study of sediment delivery in the Waipaoa catchment. Overall, the chapter is divided into four main sections. The first two sections summarise the origins of research into the sediment delivery problem and surveys approaches to estimating sediment yield and sediment delivery at the catchment scale. The third section discusses the failure mechanism of shallow earthflows and examines the influence earthflows have on the sediment yield of the Waipaoa catchments. The fourth and concluding section provides a perspective on the evolution of sediment delivery ratios, which is the main focus of this thesis.

For clarification this thesis refers to shallow rainfall triggered landslides as earthflows. The terminology landslide refers to previous research where the process was defined as 
a shallow rainfall triggered landslide and earthflow refers to rainfall triggered failures observed in this research. Therefore, while the terminology 'landslide' and 'earthflow' are used interchangeably throughout this thesis as they refer to the same feature. This type of failure only mobilizes the soil horizon and surface of weathered bedrock (Page et $a l, 1999)$, usually with a failure depth around $1 \mathrm{~m}$ and volume less than $100 \mathrm{~m}^{3}$.

\subsection{The Concept of Sediment Delivery}

The concept of sediment delivery, as outlined by Roehl (1962), is important in terms of linking landscape form and process and is imperative for the comprehension of sediment transfer through the fluvial system (Schumm, 1977). It is based on the assumption that basin sediment yield can be related to different catchment characteristics (including, for example, the characteristics of the triggering event, catchment relief, soil and vegetation cover, and conditions in stream channels), and that only a portion of the material eroded from a catchment contributes to sediment yield over a given time (Glymph, 1954). Much initial research was concerned with using empirical observations to determine which characteristics exert most influence on sediment yield (Wade and Heady, 1978), and this line of inquiry continues to the present day (Kettner and Syvitski, 2004). But at the same time it was also recognised that the different characteristics rarely remain constant within or between different catchments, so that the disparity between sediment

production and sediment yield cannot easily be explained in this manner (Glymph, 1954). Consequently, "if a characteristic ratio of sediment yield to erosion does exist it would be a most useful statistic" (Glymph, 1954, p. 198), and a considerable amount of effort has also been directed to resolving the disparity between gross erosion and sediment yield.

Sediment delivery is strongly scale dependent. At the hillslope scale, sediment delivery first increases and then decreases as catchment area increases (Parsons et al., 2006). Three explanations have been given for this scale dependency of the sediment yield. First, since hillslope runoff also exhibits the same characteristics, it may be attributed to 
spatial variations in infiltration or temporal variations in rainfall intensity. Second, the dependency arises because some of the eroded sediment is stored in hillslopes sediment sinks. Third, it is possible that as area increases the proportion of the area that contributes sediment to the outlet decreases because individual particles travel a finite distance during storm events. Regardless, the clear implication is that erosion rates measured at one scale cannot be extrapolated to another (Parsons et al., 2006). The same effect is seen at the catchment scale and is commonly observed as an inverse relationship between specific suspended sediment yield and drainage basin area (Walling, 1983), that arises because either the high erosion rates recorded in small headwater catchments are not sustained across the whole basin and/or storage reduces the amount of sediment delivered to the basin outlet. In fact, because sediment in most river systems appears to spend much more time in storage than in transport (Meade, 1982), the application of a delivery ratio is seen as an obvious way of resolving the disparity between rates of erosion on hillslopes and in-stream measurements of suspended sediment yield (Dickinson and Wall, 1977).

However, sediment delivery ratios are not easy to model or predict and Dickinson and Wall (1977) identified two apparent paradoxes that make it difficult to accurately estimate delivery ratios. First, there is the problem of spatial aggregation or lumping (the spatial paradox), which relates to the problem of attempting to represent the sediment delivery characteristics of a catchment in which topography and soils (and hence infiltration capacity, runoff and erosion potential) vary from place to place, with a single number. Burns (1979) suggested that each sediment source should be viewed as possessing a unique delivery potential, with a probability of sediment being exported from a particular source that is linked to its relative position (with respect to the stream and the catchment divide). Second, a temporal or frequency paradox arises as although sediment loads are closely linked to runoff, the frequency distribution of sediment peaks is not equivalent to the distribution of runoff peaks often due to sediment supply constraints. In the Waipaoa catchment, for example, this means that there is a poor correlation between peak suspended sediment concentration and peak discharge (Hicks et al., 2004), and very high suspended sediment concentrations can occur during 
relatively small discharge events. These issues are compounded because sediment delivery ratios are estimated at different spatial and temporal resolutions, which range from a single hillslope $\left(\mathrm{m}^{2}\right)$ to large catchments $\left(\mathrm{km}^{2} \times 10^{3}\right)$ and individual storm events (hr) to the long-term (mean annual) suspended sediment yield, and the fact that sediment availability varies in time and in space is typically ignored (Pain and Hoskin, 1970; Walling, 1983). Furthermore, the factors which control sediment delivery also vary temporarily as the landscape evolves.

At this point it is also important to note that rivers transport sediment both in suspension and as bed load and that erosion contributes sediment to each of these components (Dietrich et al., 1982). However, while suspended sediment gaugings are relatively easy to conduct, much more effort is required to obtain reliable estimates of bed load flux (Hicks and Gomez, 2003). For this reason most attempts to estimate the yield from sediment sources are associated with suspended (not total) sediment discharge. The principal exception to this is the long-term sediment yields that are determined from reservoir surveys and debris basins (Wasson et al., 1998; Lavé and Burbank, 2004).

\subsection{Sediment Delivery Ratios}

Many researchers have attempted to produce empirical equations that can be used to estimate the sediment delivery ratio for a catchment (Vanoni, 1975). It is generally accepted that the delivery ratio decreases as drainage area increases in catchments with homogeneous climate, topography and soils (Figure 2.1). However, there are uncertainties surrounding the wide range of delivery ratios reported by individual studies. A generally applicable predictive technique is lacking, and there are fundamental problems associated with the concept of a simple relationship between gross erosion and sediment yield (de Vente et al., 2007); many of which, as noted above, revolve around the two paradoxes Dickinson and Wall (1977) identified. Nevertheless, inquiry continues to be stimulated by the knowledge that defining a sediment delivery ratio makes it possible to estimate the sediment yield of (similar) 
ungauged catchments from the major variables affecting erosion in specific areas. A common way of doing this is to produce an empirical equation that relates the sediment delivery ratio to physical parameters, such as the relief ratio and catchment length (Roehl, 1962).

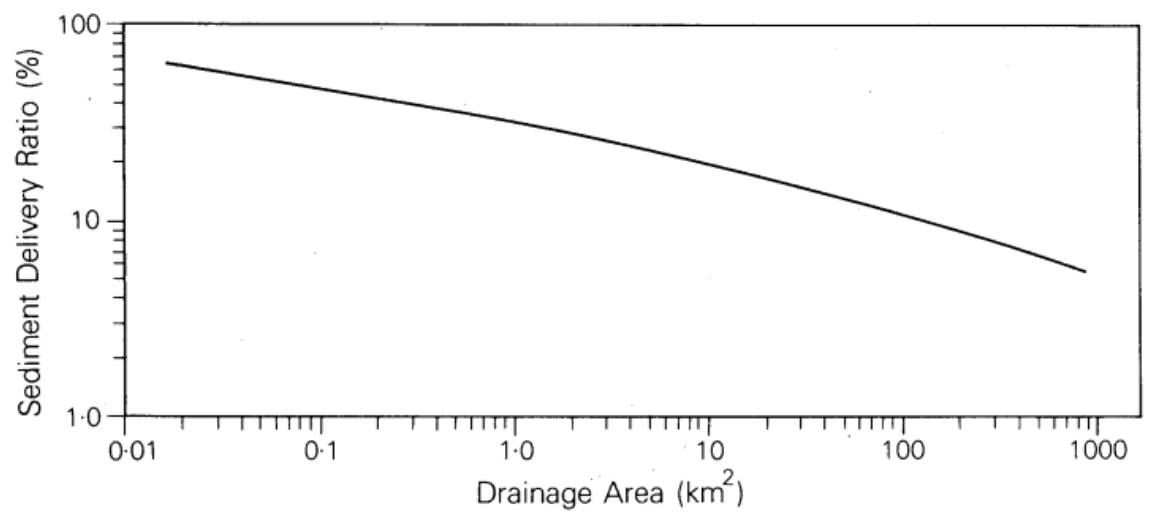

Figure 2.1 Relationship between sediment delivery ratio and the drainage basin area. Developed by the U.S. Department of Agriculture and Soil Conservation Service for central and eastern U.S.A. (Walling 1983).

Other models, such as WEPP and EUROSEM (Laflen et al., 1997; Morgan et al., 1998), attempt to account for the processes of erosion and deposition in a more explicit manner, by using physically-based equations that rely on input data with high spatial and temporal resolutions to represent individual processes. For this reason, although they can account for the spatial variability of precipitation and catchment characteristics such as slope, vegetation and soils, such models may only be suitable for specific applications. Other researchers have used a spatial modeling framework and a mixture of empirical and physically based equations, which incorporate general descriptions of catchment processes and ignore the process interactions that require more detailed information in order to gain a more universal appreciation of the patterns of sediment transport across catchments and larger areas (Prosser et al., 2001). Such models are usually implemented in a Geographical Information System (GIS) environment. Their output can be used to identify locations that are particularly susceptible to soil erosion 
(Yitayew et al., 1999; Ouyang and Bartholic, 2001; Lufafa et al., 2003), and to estimate soil loss and sediment yield at any location within a catchment.

A broader scale approach is to focus on the spatial distribution of sediment delivery ratios as opposed to sediment delivery. For example, Lu et al. (2006) used the interaction between rainfall attributes (such as intensity, duration and intermittency) and catchment characteristics (such as slope, surface roughness and channel geomorphology) to gain a better understanding of spatially distributed sediment transport processes. This was used as a guide to investigate the problem of sediment delivery at the regional scale within the Murray Darling Basin in Australia. Lu et al. (2006) interpreted the sediment delivery ratio as the catchment response to the upland erosion rate and modeled this as hillslope transport to the nearest streams. The flow was routed through the channel network, and characterised by two time related variables. The first of these is time travel, the time that particles eroded from the source area and transported through the hillslope conveyance system take to arrive in the channel network, and then to the catchment outlet. The second, rainfall duration, is the primary driving force for sediment transport. Thus, for the same rainfall event shorter travel time equates with higher sediment delivery. For similar sized source areas rainfall events of shorter duration generally deliver less sediment to the catchment outlet. The results predict that there are large local variations in sediment delivery ratios, which range from $0 \%$ on floodplains to $70 \%$ in upland regions of the catchment. Therefore, sediment residence time (storage) and the average effective rainfall duration exert a fundamental control on sediment delivery.

Although they offer a much more detailed spatial perspective on sediment delivery ratios, the observation from Lu et al., (2006) echo the conclusion of earlier studies. The local conditions and different catchment characteristics exert an important control on sediment delivery ratios (Table 2.1) so that it is unlikely that any universal relationship will emerge, even though there are characteristic trends between drainage area and specific sediment yield in catchments where particular conditions dominate (de Vente, 2007). 
Table 2.1 Examples of proposed relationships between sediment delivery ratio and catchment characteristics. (adapted from Walling, 1983).

\begin{tabular}{|c|c|c|}
\hline Author & Region & Equation \\
\hline Maner (1958) & Kanas, U.S.A & $\begin{array}{l}\log \mathrm{DR}=2.962+0.869 \log \mathrm{R}-0.854 \\
\log \mathrm{L}\end{array}$ \\
\hline Roehl (1962) & Southeastern U.S.A & $\begin{array}{l}\log \mathrm{DR}=4.5=0.23 \log 10 \mathrm{~A}-0.501 \\
\mathrm{x} \operatorname{colog} \mathrm{R} / \mathrm{L}-2.786 \log \mathrm{Br}\end{array}$ \\
\hline $\begin{array}{l}\text { Williams \& } \\
\text { Berndt (1972) }\end{array}$ & $\begin{array}{l}\text { Brushy Creek, Texas, } \\
\text { U.S.A. }\end{array}$ & $\log \mathrm{DR}=0.627 \mathrm{SLP}^{0.403}$ \\
\hline $\begin{array}{l}\text { Williams } \\
\text { (1977) }\end{array}$ & Texas, U.S.A. & $\begin{array}{l}\log \mathrm{DR}=1.366 * 10^{-11} \mathrm{~A}^{-0.100} \mathrm{R} / \mathrm{L}^{0.363} \\
\mathrm{CN}^{5.444}\end{array}$ \\
\hline $\begin{array}{l}\text { Mutchler \& } \\
\text { Bowie (1975) }\end{array}$ & $\begin{array}{l}\text { Pigeon Root Creek, } \\
\text { Mississippi, U.S.A }\end{array}$ & $\log \mathrm{DR}=0.4880 .006 \mathrm{~A}+0.010 \mathrm{RO}$ \\
\hline $\begin{array}{l}\text { Mou \& Meng } \\
\text { (1980) }\end{array}$ & $\begin{array}{l}\text { Dali River Basin, Shaanxi, } \\
\text { China }\end{array}$ & $\log \mathrm{DR}=1,29+1.37 \operatorname{In} \mathrm{Rc}-\operatorname{In} A$ \\
\hline
\end{tabular}

$D R=$ sediment delivery ratio; $R=$ basin relief; $L=$ basin length; $A=$ basin area;

$R / L=$ relief/length ratio; $B R=$ bifurcation factor $; S L P=\%$ slope of main stem channel; $C n=$ S.C.S curve number; $R O=$ annual runoff; $R C=$ gully density

\subsection{Landslides and Sediment Delivery}

As well as the processes of surface wash and rill erosion, which models such as the Universal Soil Loss Equation (USLE) accommodate, mass movements on hillslopes mantled by shallow, immature soils that support natural vegetation, forest or pasture, can make a significant contribution to the overall catchment sediment yield. At timescales relevant to coupling within fluvial systems (decades to millennia), landslides that involve "the downward and outward movement of slope forming materials under the influence of gravity" (Varnes, 1978) are one of the most prevalent mass movement 
processes affecting New Zealand's land area in general (Eyles, 1983), and the Waipaoa catchment in particular (Reid and Page, 2002).

Earthquake-triggered landslides are caused by seismic shaking which reduces the strength and/or cohesion of rock and soil (Keefer, 1984; Malamud et al., 2004), and usually occur independently of the rainfall events that deliver sediment to channels. For this reason the debris they generate often stays on hillslopes and has the potential to impact sediment fluxes for years or decades (Lin et al., 2008; Koi et al., 2008). Slopeclearing events can also block valleys with deposits that, depending on the size of the debris and transport capacity of the river, may be dispersed rapidly or reworked over a protracted period of time (Adams, 1981; Pearce and Watson, 1986). In some cases, for example, Lake Tutira in New Zealand, landslide dams can persist and influence downstream sediment fluxes for thousands of years (Eden and Page, 1998).

Rainfall is the primary climatic driver of landslides (Crozier, 1997). In New Zealand such failures are commonly associated with intense high magnitude, low frequency rainstorms or moderate rainstorms with wet antecedent conditions (Crozier, 1986). Earthflows usually occur along a discrete boundary, such as the contact between soil or regolith and the underlying bedrock, and consequently the depth and maturity of the soil profile in many parts of New Zealand are limited by the frequency with which these failures occur (Trustrum and DeRose, 1988; DeRose et al., 1993). They typically involve relatively shallow $(\leq 0.5-1 \mathrm{~m})$ translational downslope displacements of soil and regolith that generate thin tails of debris (Page et al., 1994; Reid and Page, 2002). Equations provide the basis for mechanistic approaches to determining the potential for hillslope failure (Iverson, 2000), which typically occur abruptly and can accelerate downslope if the soil liquefies (Iverson et al., 2000). Strain softening (a decline in stress as strain increases) is thought to be an important factor that operates in some debris tails during transport, which are often able to flow more extensively than predicted from soil properties alone (Crozier, 1996), and commonly extend downslope for a distance that often greatly exceeds the dimensions of the original scar (Figure 2.2). Extreme events 
can also generate hundreds or thousands of landslides (Figure 2.3), with a spatial pattern that is closely related to the rainfall distribution (Omura and Hicks, 1992).

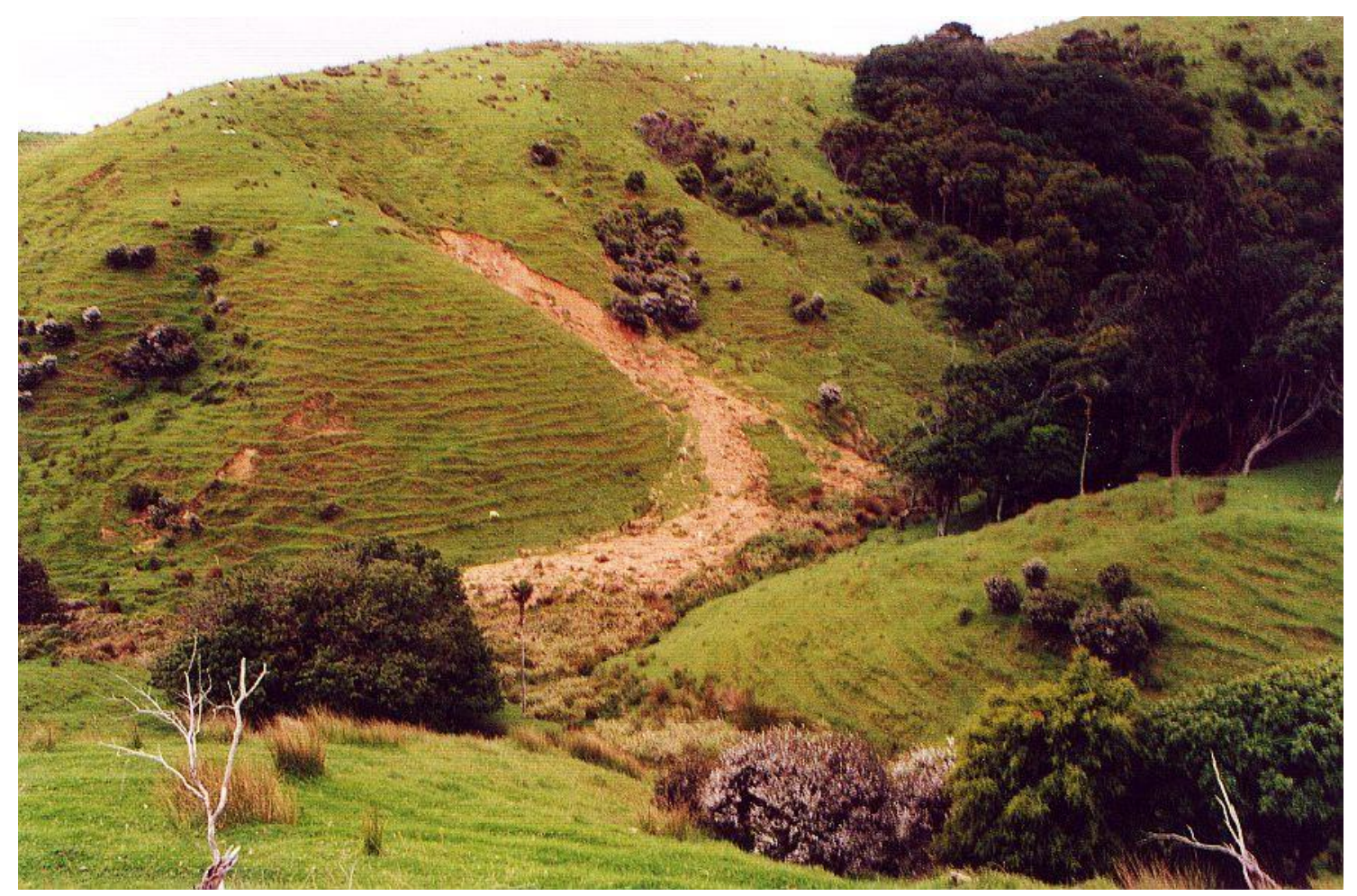

Figure 2.2 Lateral spread of the debris tail runout from an earthflow scar in the Coromandel, New Zealand. (Photo: N. Preston, 1999). 


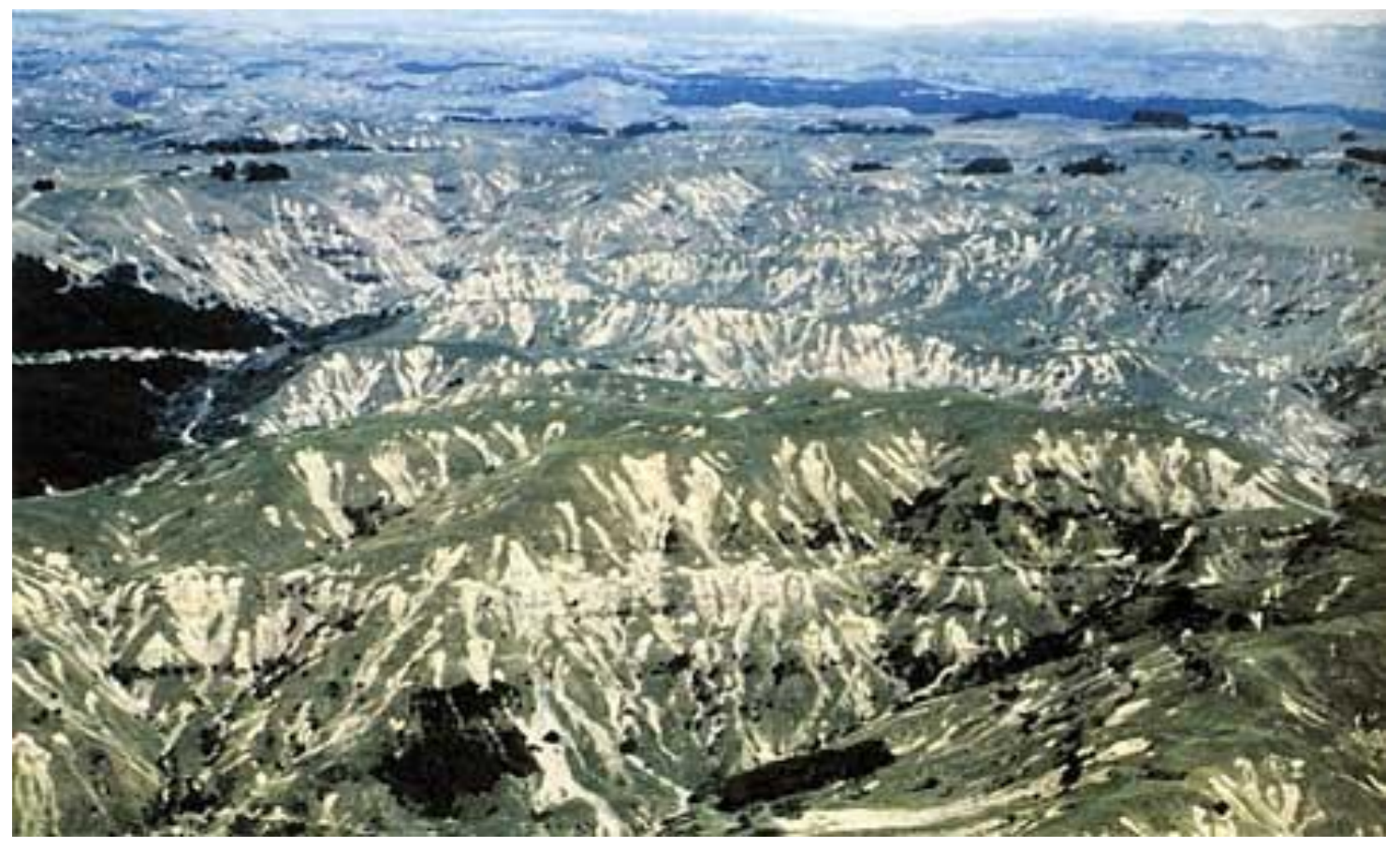

Figure 2.3 Extensive landsliding in the Hawke's Bay region, New Zealand, resulting from Cyclone Bola. (Photo: N. Trustrum, 1988).

Rainfall intensity and duration has also been analysed to determine the values that trigger landslides. Empirical analysis of storm characteristics has been shown to have potential for determining the conditions under which failures can occur (Hong et al., 2006). However, experience suggests that the exact conditions for failure are extremely difficult to identify when spatial variations in rainfall are considered in conjunction with topographic factors (Casadei et al., 2003), and that knowledge of the accumulated rainfall is also required to effectively characterize the conditions that cause slope failures.

GIS-based models can give a spatial perspective on hillslopes and the topographic parameters that are important to the movement and distribution of water on hillslopes. For example, the topographic wetness index $(T W I=\ln (a / b \tan \theta$ where: $a$ is the local upslope contributing area; $b$ is the unit contour length; and $\theta$ is the local slope) is one measure that can be derived from a digital terrain model (DTM) and is often used to quantify the influence topography has on hillslope hydrology (Beven and Kirkby, 1979; 
O'Loughlin, 1986). Locations where the index is higher, due to a large specific catchment area $(a / b)$ or low slope, are more likely to be saturated with water than dry.

Crozier (1999) developed an empirical model that takes into account the contributions made by antecedent soil water as well as event water (indexed by soil water status and daily rainfall, respectively). Negative values of the soil water status indicate conditions that are below field capacity, and positive values indicate conditions where water preferentially accumulates on hillslopes in locations where the contours are concave and flow lines converge. If the storage capacity (porosity and depth) of the regolith and soil, the rate of evapotranspiration, and the rate of drainage in excess of precipitation are known the soil water status can be determined. Crozier (1999) recorded excess rainfall over a 10-day period when calculating the antecedent soil water status and determining the conditions under which rainfall-triggered landslides occur in Wellington. However, the number of days required for antecedent soil water to drain and water to accumulate depends on the texture and depth of soil or regolith and other factors that typically vary from region to region (Glade et al., 2000). This highlights the important point that irrespective of whether a mechanistic or empirical approach is used, defining the circumstances under which landslides occur involves the identification of the threshold value that separates landslide conditions from stable conditions. In the Waipaoa catchment, for example, significant rainfall triggered landsliding occurs when rainfall exceeds a threshold value of $\sim 200 \mathrm{~mm}$ in 72 hours ( Dymond et al., 1999; Reid and Page, 2002).

Threshold effects on erosion processes operating in terrain that exhibits varying degrees of susceptibility to different erosion processes are also responsible for spatial variations in the characteristics of suspended sediment discharge in rivers draining the East Cape region of New Zealand's North Island (Hicks et al., 2000 and 2004). Rating-based magnitude - frequency relationships show how the signature of different erosion processes is imprinted on catchment suspended sediment yield (Hicks et al., 2000 and 2004). Relationship curves for catchments where gully erosion generates sediment during storms of all magnitudes are flatter than those for rivers where the sediment load 
during sub-annual (low-magnitude, high-frequency) runoff events is low as rainfall triggered landslides only generated sediment during high-magnitude low-frequency storms. Here, as in other parts of New Zealand, average landslide sediment fluxes have been quantified using aerial photography as a basis for deriving magnitude-frequency relations (Hovius. et al., 1997; Reid and Page, 2002).

Page et al. (1999) and Reid and Page (2002) used aerial photography in conjunction with rainfall data to derive relationships between storm magnitude and landslide density on different forest and pasture and systems in the Waipaoa catchment. Based on field measurements of 95 landslide scars, average volumes for landslides in each land system were measured. The overall sediment delivery ratio was estimated to be $45 \%$ and the percentage of sediment contributed by shallow landslides to the suspended sediment load of the Waipaoa river at Kanakanaia is $\sim 15 \pm 5 \%$ (Reid and Page, 2002), which rises to $\sim 48 \%$ during extreme events (Page et al., 1999). Thus, in the Waipaoa catchment, where gully, sheet and riverbank erosion have the potential to generate sediment whenever it rains, the cumulative effects of low magnitude, high frequency events dominate the long-term catchment sediment yield (Hicks et al., 2000).

\subsection{Evolution of Sediment Delivery}

Large magnitude, low frequency events in the Waipaoa catchment mobilize large amounts of sediment on hillslopes. However, much of this material goes directly into storage, and so landsliding makes a smaller relative contribution to sediment yield than in catchments where sediment delivery is more efficient because connectivity between hillslopes and channels is enhanced (Page et al., 1994). Sediment in temporary storage on hillslopes that is released by subsequent small events complicates the event magnitude-frequency distribution of suspended sediment loads for up to three years if landslide scars and tails remain unvegetated (Hicks et al., 2000). Therefore, much of the sediment attributed to gullying and sheet erosion during low magnitude, high frequency 
events could actually be derived from the higher magnitude, low frequency multiple occurrence landslide events.

But since new soils take much longer to develop on landslide scars (Trustrum and DeRose, 1988), repeated landsliding rarely occurs on previously failed surfaces. Instead, landslide scars retreat upslope (Figure 2.4). This is directly influenced by the frequency of the storm events. A study undertaken by Thomas and Trustrum (1984) with soil slip scars in the Wairarapa region of the lower North Island of New Zealand, modeled scar location patterns. The oldest scars observed in this study were pre-1941 and occurred immediately adjacent to the lower ephemeral channels and at the base of the hillslopes. In subsequent failure events, the scars occurred progressively up the slopes towards the interfluves and eventually at the ridge crests. Trustrum et al., (1984) calculated a $2.8 \%$ increase per decade for the period 1930 to 1977 for the rate of encroachments of failures on soil which has been stable since the native forest removal. Yet Trusturm et al., (1984) also suggest this rate of erosion is not sustainable for long periods of time. This suggests an increase in the triggering threshold required for soil erosion where storms of similar magnitude may not produce comparable sediment yields. Therefore, the frequency and magnitude of landsliding events is important in relation to the evolution of landslide scar locations relative to both the channel and position within the catchment. 

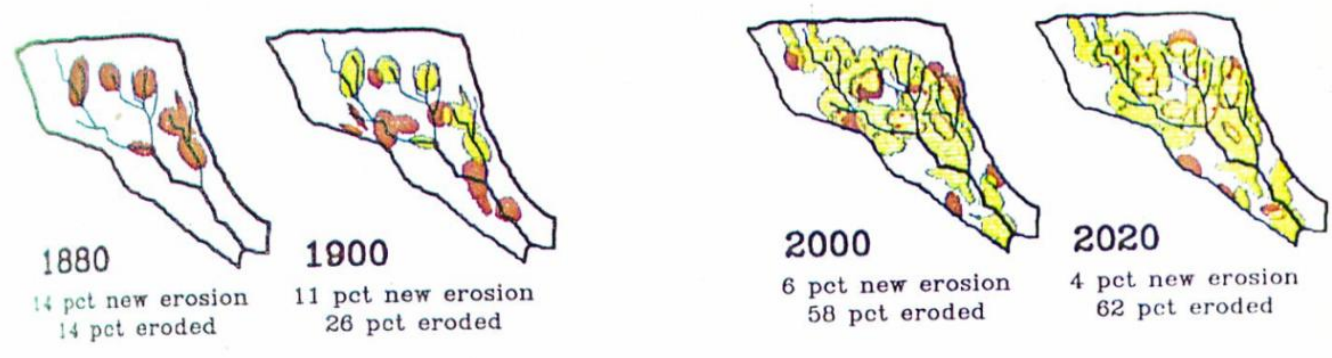

6 pet new erosion 4 pet new erosion

4 pct eroded 26 pct eroded

58 pet eroded

62 pet eroded

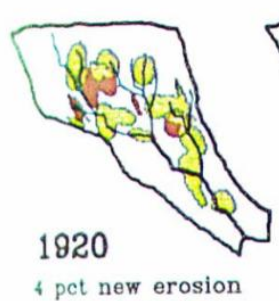

4 pet new erosion

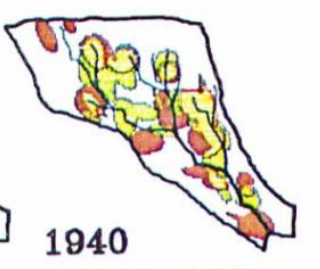

14 pct new erosion

44 pet eroded

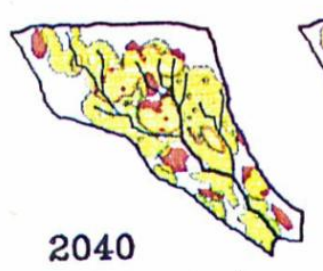

6 pet new erosion 68 pet eroded
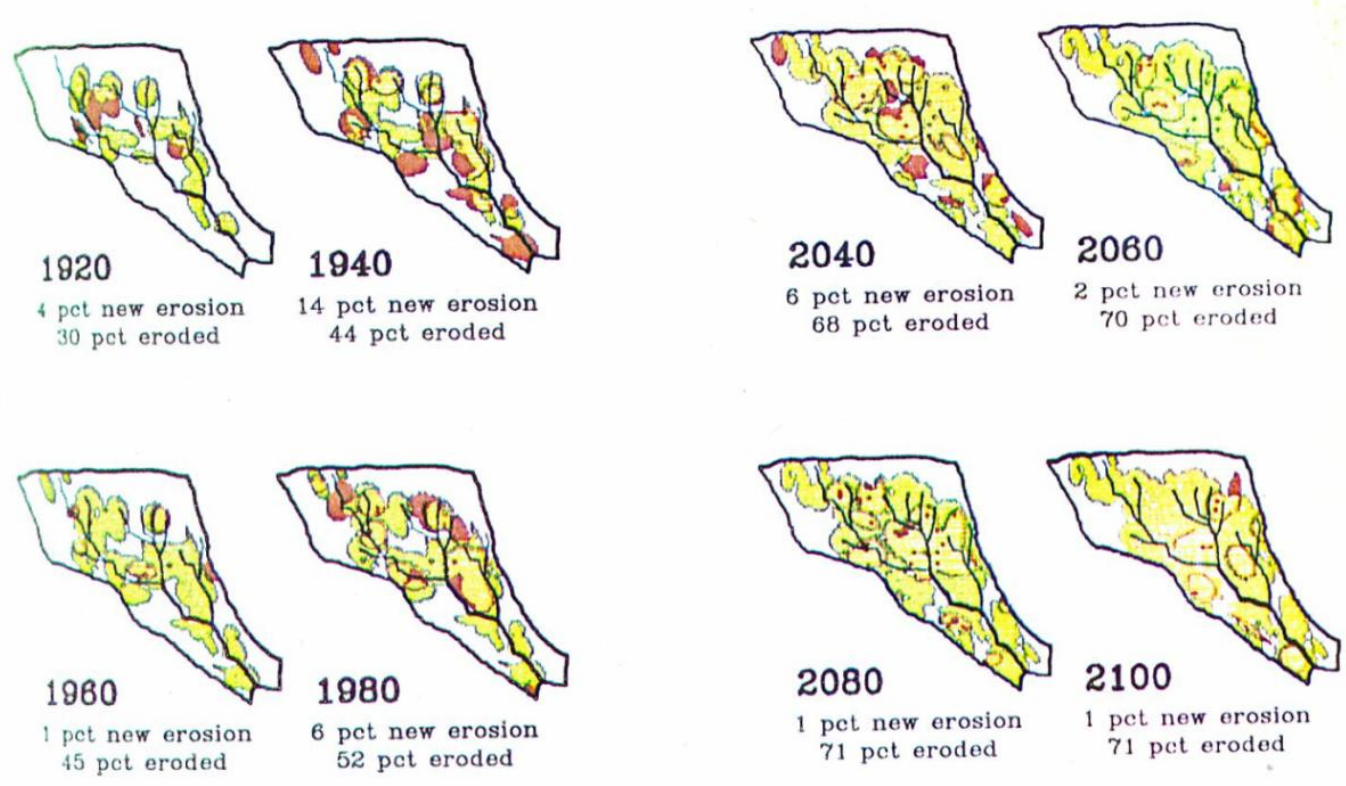

1 pet new erosion 71 pet eroded

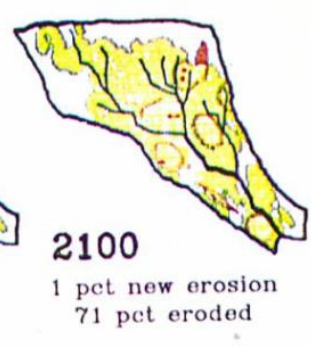

EI Previous erosion

New erosion Overlap

1 Previous erosion

New erosion 5 Overlep

Figure 2.4 Historical (left) and simulation (right) models for failures on the Wairarapa hillslopes, New Zealand. Shown is the upslope development of landslide scars with time resulting in the lowering in frequency of the fresh regolith failures compared to reactivation of old scars. (Thomas and Trustrum, 1984). 
Moreover, even if the magnitude and distribution of storm rainfall remains constant over time (which is not usually the case), the distribution of erosion events will also vary across the landscape. The effect is exacerbated by particular assemblages of landforms, soils and natural vegetation, so that different relationships between storm rainfall and landslide frequency apply to different portions of the Waipaoa catchment (Reid and Page, 2002). In effect, the different land systems each have their own unique history of erosion events so that the triggering threshold for landslides varies from hillslope to hillslope. It has also been suggested that, because the erosion processes that drive sediment fluxes are spatially and temporally variable over a large range of scales, disturbance events and topography can interact to create patches of intense erosional activity (Miller et al., 2003).

Land use practices also impact the threshold for landsliding. Timber harvesting and the conversion of native forests to pasture, for example, decreases hillslope stability and makes the terrain more susceptible to erosion because the cohesion of soil and regolith declines as tree roots decay and the succeeding vegetation intercepts and transpires less water (O’Loughlin and Ziemer, 1982; Montgomery et al., 2000; Schmidt et al., 2001; Roering et al., 2003). Across New Zealand, areas of hill country underwent conversion from indigenous forest and scrub cover to pasture after European settlers arrived in the $19^{\text {th }}$ century. Crozier and Preston (1999) refer to the anthropogenic increase in erosional activity as the Post-European Settlement Regolith Stripping Phase. This has important implications for the response of the catchment to storm events due to the different stages of catchment evolution as outlined by Crozier and Preston (1999) (Figure 2.5). Based on a comparison of measured soil depths in first-order catchments in Taranaki basins, there was a 10-fold increase in the erosion rate post-deforestation (De Rose et al., 1993). In the Wairarapa, Thomas and Trustrum (1984) showed that there was an exponential decrease in the availability of uneroded regolith after deforestation (Figure 2.6). Lake sediment records also document the acceleration of hillslope erosion after European colonists removed the native forest and converted the land around Lake Tutira to pasture. Sedimentation rates in Lake Tutira with the surrounding catchment under pastoral land use are between $5 \sim 6$ times the rate under fern/scrub, and 8 to 17 times the 
rate under indigenous forest (Page and Trustrum, 1997). Finally, simulations suggest that the suspended sediment discharge of the Waipaoa River increased from $2.3 \pm 4.5$ to $14.9 \pm 8.7 \mathrm{Mt} \mathrm{yr}^{-1}$ in the late $19^{\text {th }}$ and early $20^{\text {th }}$ Centuries (Kettner et al., 2007).

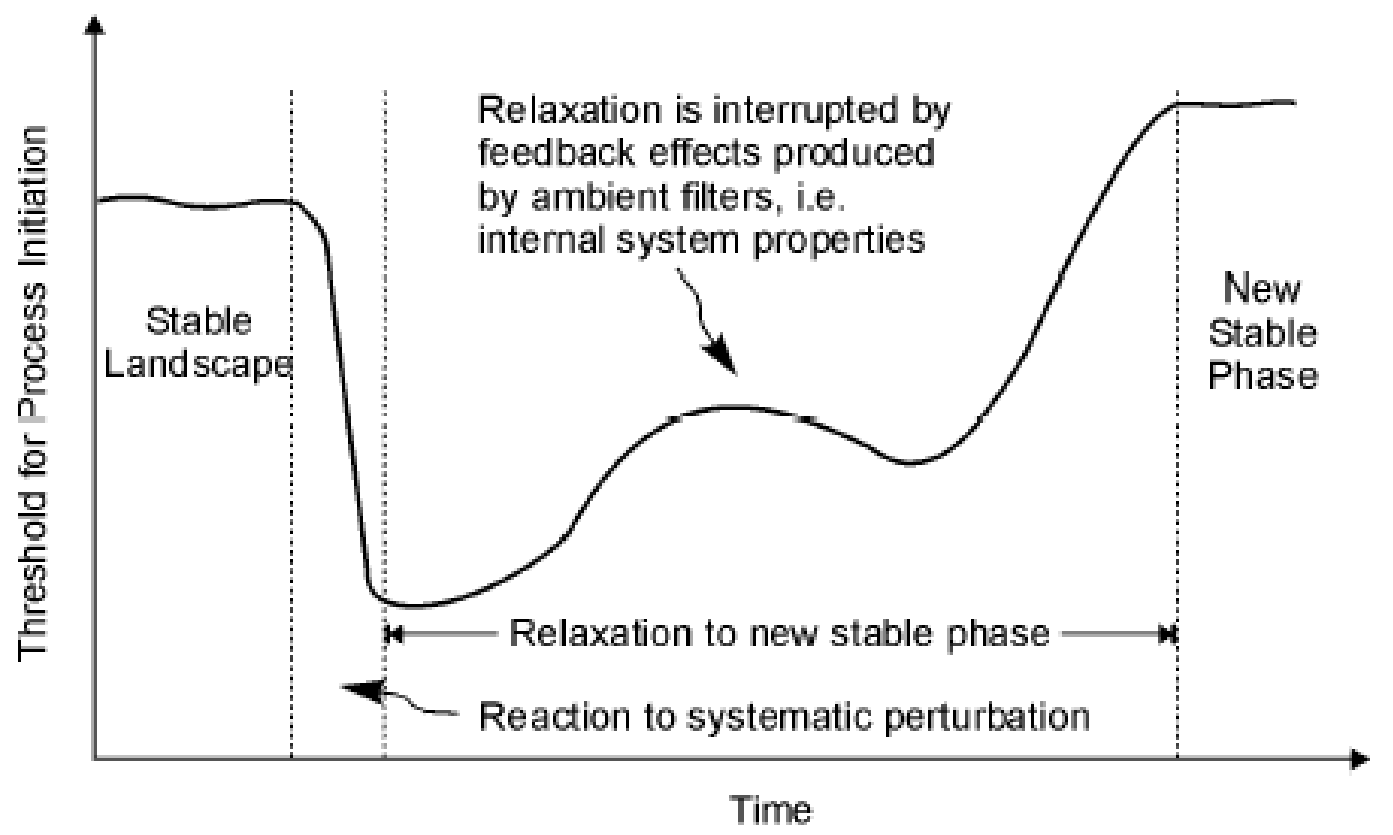

Figure 2.5 Terrain Event Resistance Model. (Crozier and Preston, 1999). 


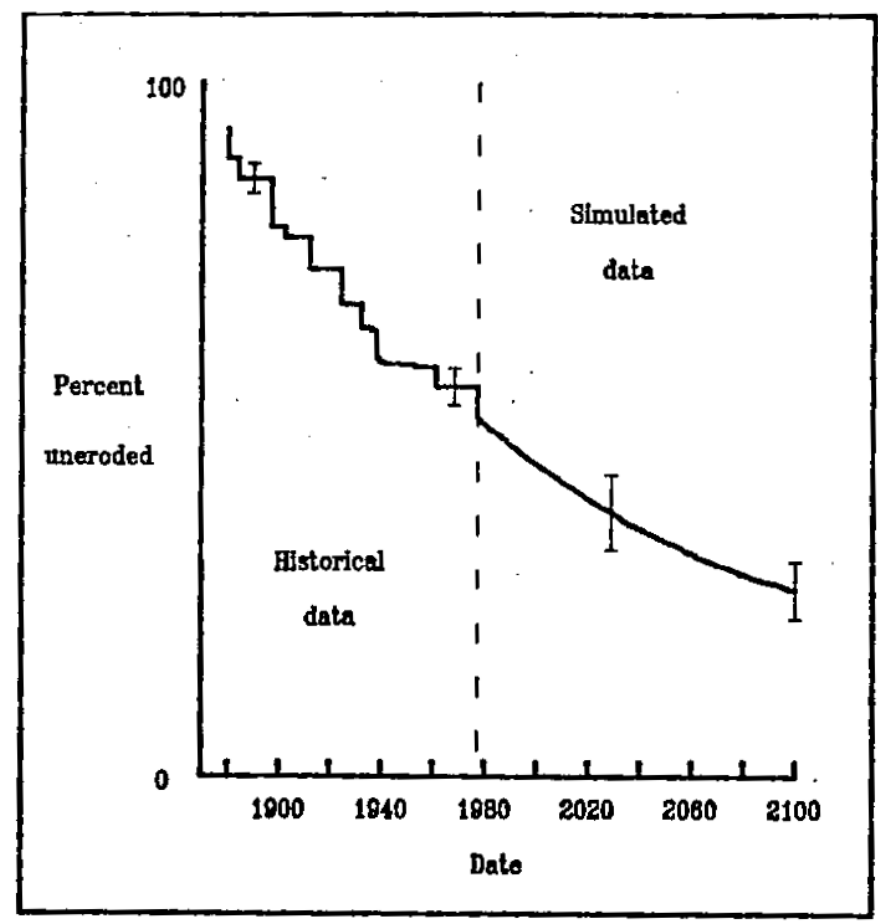

Figure 2.6 Average percentage ground uneroded since deforestation of the slopes. Standard deviation derived from 100 simulation runs is also shown. (Thomas and Trustrum, 1984).

This implies that the sensitivity of the landscape, as defined by the threshold value that must be reached or surpassed before motion is initiated, varies over time (Crozier and Preston, 1999; Brooks et al., 2002). While rainfall triggered landslides are a dominant erosion process in Tertiary hill country around New Zealand, the conversion from forest to pasture has lowered the threshold of the event which creates heightened slope instability. The stripping of the regolith layer progressively moves upslope with subsequent failures and undelivered sediment is deposited at the base of the slope (Figure 2.7). The newly exposed bedrock is less permeable than the pre-existing regolith cover. The three phases identified by Crozier and Preston (1999) and Brooks et al. (2002) for modelling purposes are further defined below: 
1. Undisturbed Regolith: immediately following forest clearance and involving completely undisturbed regolith where there is little evidence of any past landslide activity.

2. 50\% Stripped Regolith: intermediate stage where slopes have had about 50\% (by area) of their regolith stripped. This is usually the case after several decades under pasture.

3. Redeposited Regolith: advanced stage in which landslide debris accumulated as colluvial footslopes has ripened and become itself susceptible to earthflow occurrence.

The modification of these slopes results in changes to the geotechnical and hydrological properties of the slope. Thus, there are changes to the triggering threshold for future failures. As a consequence, the hillslopes become more stable as the system moves towards a new stable phase. However, these alterations in the both the hydrological and geotechnical conditions of the slope due to regolith removal and redeposition adds more complexity to this relationship. Brooks et al. (2002 pg.173 \& pg. 176) states that "that slope failure might be controlled by different hydrological behaviour for each of the different phases of regolith stripping described above" and goes on to say that "the thresholds for instability are related to the prevailing types of storm, with the relative stability of the stages depending on the storm properties." 


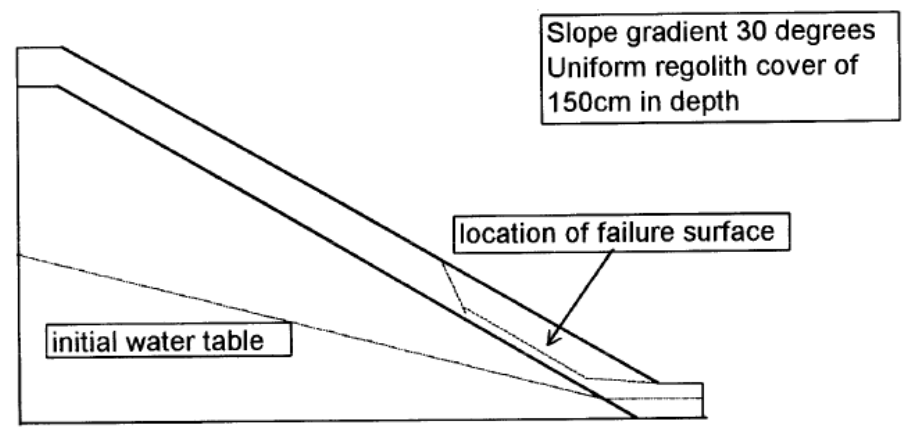

b) $50 \%$ stripped regolith

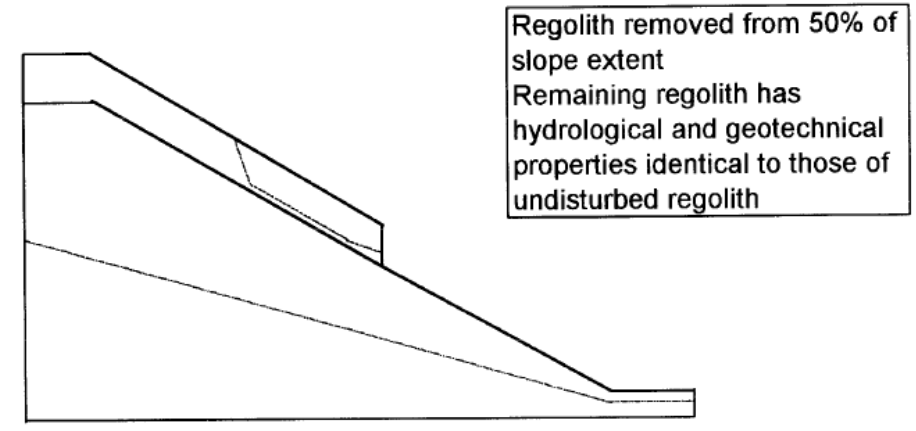

c) Redeposited regolith

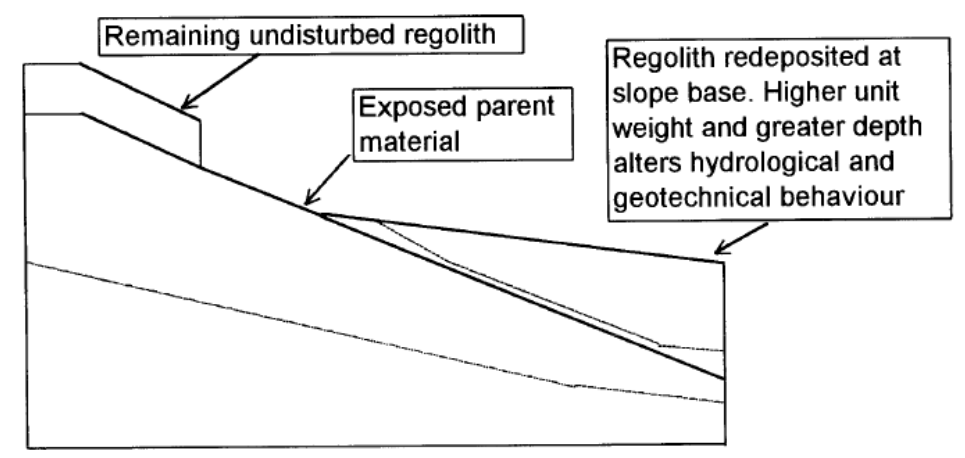

Figure 2.7 Changes in the location of landslide scars due to regolith exhaustion. A) Failures first occur on the lower slopes due to a build up of pore water pressure under gravity. B) After the removal of this material the failures retreat up slope to fresh regolith. C) Undelivered sediment builds up on the lower slope and ripens until the lower slopes are once again prone to failure. (Brooks et al., 2002). 
Using a process based model, Brooks et al., (2002) defined the failure mechanisms under these altered hydrological and geotechnical conditions resulting from changing triggering thresholds. During long duration, low intensity storm events the undisturbed regolith still remaining on the hillslope is the most susceptible to failure. Whereas, during high intensity, short duration events the redeposited regolith at the base of the slopes is the most susceptible to failure. Yet the redeposited colluvial footslope remains less likely to fail compared to the undisturbed regolith further upslope. Brooks et al., (2002) suggests that the higher unit weight, friction angle and cohesion that develop during consolidation of the material offset these higher pore water pressures which occur towards the base of the slopes.

So, changing landslide thresholds relates to a pattern in landslide location on the slope and this directly influences sediment delivery. As the failure zone retreats up the slope the distance sediment has to travel before it is entrained in the fluvial network also increases. Therefore, we could assume a high delivery ratio under a natural system (where failures are located at the base of the slope due to the build up of pore water pressure under gravity) due to the close proximity of the failures to the fluvial network. However, the catchment sediment delivery ratio is expected to decrease as the distance between scars and the fluvial network increases over time and lower percentages of sediment are delivered off-slope.

Dymond et al. (1999) combined GIS layers depicting rainfall, vegetation cover and other terrain characteristics with a high-resolution DTM to calculate the probability of landslides occurring at different points and delivering sediment to streams in the Waipaoa catchment. Debris tail depth and runout distance vary with slope angle, which exerts a dominant control on erosion processes such as landsliding and determines the ability water has to transport landslide derived sediment across hillslopes and into stream channels (De Roo, 1998). On steep slopes debris tail depths are small and runout lengths are long, and for a given vegetation type (forest or pasture) the probability of landsliding depends on storm rainfall, slope angle and rock type (which determines regolith strength). Dymond et al., (1999) estimated $30 \pm 5 \times 10^{6} \mathrm{~m}^{3}$ of soil was eroded 
during the largest storm on record (Cyclone Bola in 1988), with $13 \pm 3 \times 10^{6} \mathrm{~m}^{3}$ of soil reaching stream channels when using a spatially variable sediment delivery ratio. For each connected landslide Dymond et al., (1999) modelled the depth of the sediment deposited on the hillslope from the debris tail and from this determined the total volume of sediment delivered to the stream compared to the volume of the scar. Dymond et al., (1999) were able to estimate the occurrence of landslides on a pixel scale and model the spatial distribution of sediment delivery ratios which varied (from $20 \%$ to $54 \%$ ) across different terrain types. Spatially variable sediment delivery ratios were determined by comparing the total volume of sediment delivered to the streams compared to the total volume of sediment produced for each given area.

For comparison, Page et al. (1999) estimated from their relationship between rainfall and landsliding that the same storm would generate $33 \times 10^{6} \mathrm{~m}^{3}$ of soil, $16 \times 10^{6} \mathrm{~m}^{3}$ of which entered stream channels when assuming a universal sediment delivery ratio of 50\%. In contrast Preston (2008), determined the direct off slope sediment delivery to the drainage network from the percentage of the failed mass remaining within the boundary of failure scars and in storage on the slope. This was undertaken in three small catchments within and to the south of the Waipaoa catchment on the low lying coastal hills following a large storm in 2002. Here, the overall estimated off-slope sediment delivery ratio was $26 \%$ for these catchments but the overall catchment delivery ratio is unknown. However, differences between these studies must be highlighted. Preston (2008) observed sediment delivery from landslides on coastal hill country where the gentler slopes with footslopes abut alluvial terraces. In comparison, much of the Waipaoa hill country is steep and slopes abut stream channels. Storm rainfall for the two studies also varied as the total storm rainfall at the Hinenui site (Preston, 2009) was $\sim 300 \mathrm{~mm}$, whereas the higher sediment delivery ratios estimated for Cyclone Bola were for a storm rainfall of $\sim 600 \mathrm{~mm}$. But it remains that as Dymond et al. (1999, pg. 127-8) emphasise, although the "statistical nature of landslide occurrence and depth is known and the process of sediment delivery is also known, the spatial pattern of erosion and deposition resulting from the interaction of the two is not." 


\section{Chapter Three: The Waipaoa Catchment}

\subsection{Introduction}

This chapter provides an introduction to the wider field area used in this study: the Waipaoa River Catchment located in the East Cape of the North Island, New Zealand (Figure $3.1 \mathrm{~A}$ ). The total size of the catchment to the river mouth is $\sim 2205 \mathrm{~km}^{2}$ with 85 percent of the catchment classified as hill country (Page et al., 1999). The Waipaoa River originates in the northern-most part of the catchment $1200 \mathrm{~m}$ above sea level as the Upper Waipaoa where it is joined by the Mangatu, Waingaromia, Wharekopae, Waikohu, Waihuka and Waihora tributary rivers. The Te Arai River is the southern most tributary and joins the Waipaoa River on the alluvial plain before it flows out to sea at the southern end of Poverty Bay (Figure 3.1 B). Predominantly a gravel bed river, its morphology changes from a braided configuration in the upper $12 \mathrm{~km}$ to a single thread meander in the middle and lower reaches (Rosser, 1997). The mean suspended

sediment concentration is $\sim 1700 \mathrm{mgL}^{-1}$ and the annual average suspended sediment yield to Poverty Bay is estimated at 15 million tons (Hicks et al., 2000). This sediment yield ranks as one of the highest measured in New Zealand compared to basins of comparable size (Hicks et al., 1996) and again is high by global standards (Milliman and Meade, 1983; Walling and Webb, 1996). 

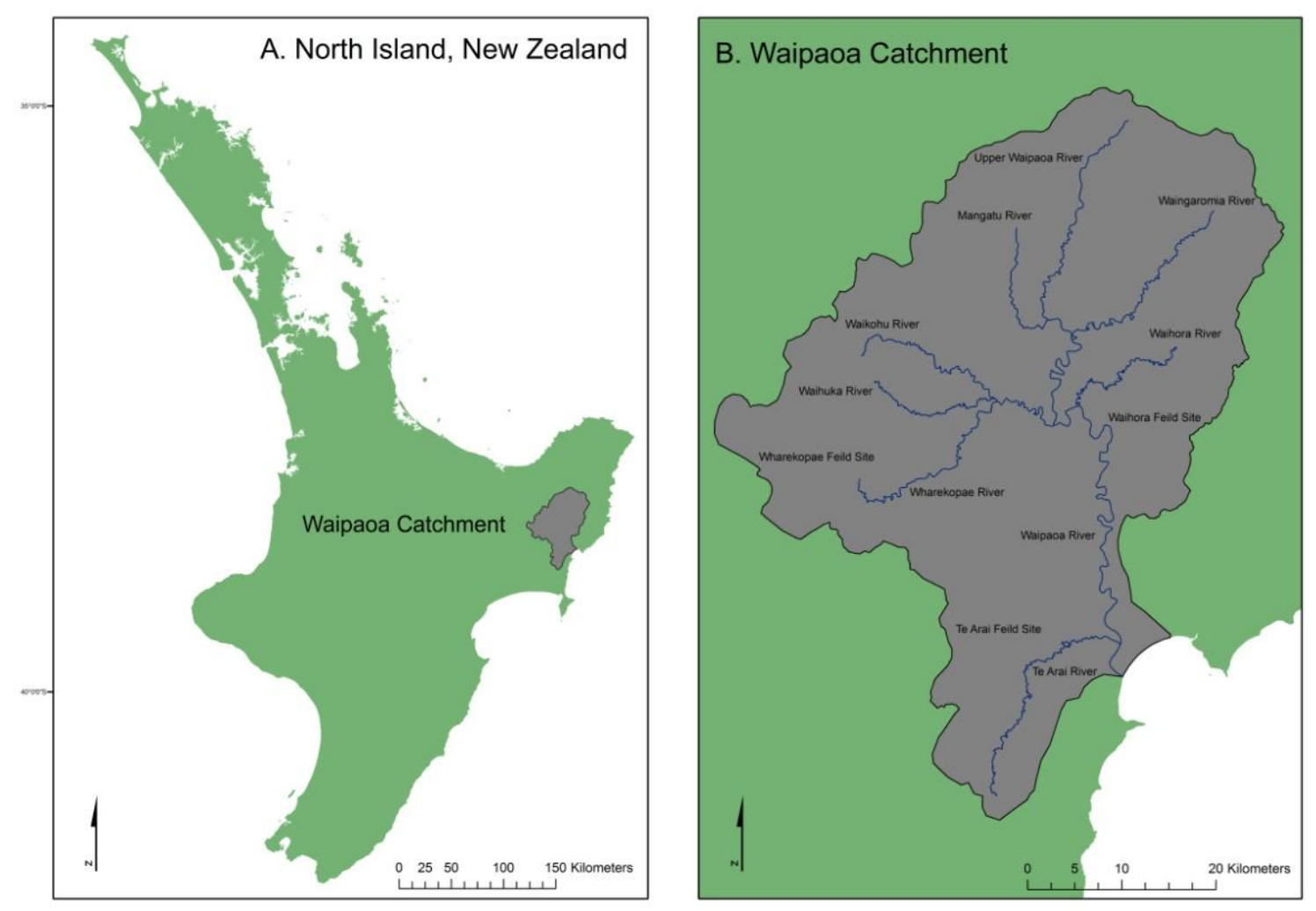

Figure 3.1 A) Location of the Waipaoa Catchment in the East Cape region of the North Island of New Zealand. B) The main tributaries to the Waipaoa River in the Waipaoa Catchment.

High erosion rates and sedimentation result from a combination of geological, geomorphic, climatic and anthropogenic factors and allow for the observation of the sedimentary system both in contemporary scales and over the longer geological timeframe. Because of this the Terrestrial Landscape Change: MARGINS Source-toSink New Zealand programme uses this site as its North Island East Coast (NIEC) catchment to "develop a quantitative understanding of how landscapes respond to everchanging global environmental drivers and human intervention". The research for this thesis is one small part of this larger project, using selected sub-catchments within the Waipaoa Catchment to quantify hillslope and channel linkages to determine sediment delivery from shallow landslides at a range of spatial and temporal scales. 


\subsection{Geological Setting and Geomorphic Processes}

Catchment geology, structure and tectonics are considered to predispose this landscape to high rates of geomorphic activity. The Waipaoa catchment is situated within a zone of active deformation in the active forearc margin of the Hikurangi subduction trench, a convergent plate boundary between the Pacific and Australian plates. Late Miocene to recent normal faulting is widespread (Mazengarb et al., 1991) and where regional uplift is in the order of 1 to $3 \mathrm{~mm} / \mathrm{yr}$ across the basin. Uplift peaks in the headwaters at 10 $\mathrm{mm} / \mathrm{yr}$ shifting to slight subsidence near the coast (Pillans, 1986) in response to deep seated subduction processes such as sediment underplating (Walcott, 1987; Litchfield et al., 2007). Due to this tectonic setting the underlying rocks are highly deformed and weak, giving landforms of varying degrees of stability.

The headwaters of the Mangatu and Waipaoa Rivers, representing $~ 8 \%$ of the catchment, are underlain by a structural complex of Cretaceous and early Tertiary sedimentary rocks. Strongly jointed sandstone/argillite, siliceous argillite, smectitic mudstone, marl and limestone result in highly unstable landforms despite being more indurated than the strata found throughout the rest of the catchment. The strongly jointed nature and presence of smectitic clay results in extensive hillslope erosion with earthflows, slumps, and gully erosion being a major source of sediment throughout the Quaternary (Gage and Black, 1979). The large amphitheatre-like gully complexes develop in the highly sheared rocks and mobilize large amounts of both fine and coarse sediment (Gage and Black, 1979).

The erosion thresholds are low for gullying (and similar erosion processes involving scour by runoff) which is activated by rainfall events of all magnitudes and frequencies meaning they have the potential to supply sediment whenever it rains. $43 \%$ of the catchment's annual sediment load is generated from these mass movement complexes (Marden et al., 2008) predominantly in the upper catchment resulting in downstream bed aggradation. There is evidence that many of these gully systems existed before deforestation either as incipient gullies or slump heads. Landslide buried logs have been 
exposed in current gully complexes (Allsop, 1973) and the age of the slump heads have been suggested as predating the $\sim 12,000$ year B.P. Waiohau tephra. Other gullies date from before the 1850 years B.P. Taupo eruption (Gage and Black, 1979).

Throughout the rest of the catchment Miocene to Pliocene interbedded sandstone/mudstone and mudstone with lesser amounts of sandstone and limestone is the prevalent geology. Many of the alluvial terraces found throughout the Waipaoa catchment are developed on this Miocene - Pliocene cover sequence. These terrace deposits located in the mid to upper parts of the catchment represent climatically driven cycles of alternating aggradation and incision over the last 100, 000 years (Berryman et al., 2000). The structure of these sedimentary rocks contributes greatly to high erosion rates within the Waipaoa catchment, although these strata are less susceptible to mass movement processes except where faulted. Volcanic ash fallout deposits from the Taupo Volcanic Zone remain only on the stable hillslopes and rounded ridgetops in the upper catchment (Allsop, 1973). Downstream the hillslopes are more steeply incised with gully erosion and slumping.

Both active and relict large deep seated slumps (Pere, 2003) are common throughout the catchment either seismically triggered, reactivated by wet antecedent conditions or toe removal by fluvial undercutting. Alternatively many of the relict earthflow/ slide complexes have been active over longer timescales with slope instability triggered by post-glacial valley downcutting or nick-point retreat (Marden et. al., 2008) in the upper parts of the Waipaoa catchment.

Throughout the catchment the Miocene - Pliocene hillslopes are also prone to shallow landslides and earthflows defined as planar failures moving as a highly mobile debris flow that mobilize only the soil profile and surface of weathered bedrock (Page et al., 1999). The shallow landslides are activated by relatively infrequent high intensity rainstorm events and typically only occur extensively when individual storm rainfall exceeds a threshold of between 220 and $360 \mathrm{~mm}$ (Reid and Page, 2002). They have a dramatic impact on the landscape but only following high magnitude low frequency 
storm events. For this reason, their annual sediment contribution is minor contributing only 10 to $25 \%$ of the total long term sediment yield of the Waipaoa River (Trustrum et al., 1999; Hicks et al., 2000; Reid and Page, 2002). Yet this contribution rises to 64\% of the sediment yield during large magnitude events like Cyclone Bola (Page et al., 1999).

In the mid to lower reaches of the Waipaoa River are mid-Quaternary lacustrine, fluvial and lagoonal deposits. Much of this material is remobilised in the fluvial system either after being temporarily stored within the channel itself or re-entrained by undercutting and slumping of material previously deposited on the alluvial plains.

\subsection{Climate and Vegetation History}

Pollen evidence suggests that vegetation throughout the Waipaoa catchment over the last 40,000 years has varied but there has been the persistence of podocarp-broadleaved species (Allsop, 1973). The early Holocene climate was warmer and wetter than present (Mildenhall and Brown, 1987) with full forest cover throughout the catchment. During the coldest periods of the glacial however grass and scrub cover will have colonised the hillslopes (McGlone et al., 1984). Maori settlements in the Waipaoa catchment date from 700 year B.P. on the alluvial silt loams and more densely populated $\mathrm{Pa}$ sites date from 350 years B.P. (Jones, 1988). Maori settlements were mainly on the southwest of the lower reaches of the catchment with the earliest occupation in the Matawhero vicinity. Dense settlements were also located on the principal fans at Waerenga a Hika, Patutahi and Manutuke (Jones, 1988). Vegetation was cleared by slash and burn for horticulture on the hillslopes towards the coast and intensive crop growing on the river banks and foothills was limited to the frost free areas of the catchment.

European settlement began in the late 1830s (MacKay, 1982) with the main settlement on the alluvial plains to the north of the Waipaoa River with a scattered rural population throughout the surrounding hill country. Primarily forest was cleared to make way for 
production pasture and by 1880 most of the lower reaches of the catchment had been cleared. The headwaters were cleared of native forest cover by 1920 (Henderson and Ongley 1920; MacKay, 1982). Extensive pastoral farming developed in the hill country and intensive horticulture on the alluvial plains. The establishment of pastoral farming initially provided the basis of the Gisborne District economy. However, the decline in the economic viability of pastoral farming combined with high erosion rates in hillslopes under pasture lead to the rapid growth of production forestry. In the 1960s the New Zealand Forest Service began to plant the severely eroding areas of headwaters with exotic forest, principally Pinus radiata, (DeRose et al., 1998; Gomez et al., 2003; Marden et al., 2005) with commercial timber harvesting starting in the 1990s. Now only $6 \%$ of the catchment is covered in indigenous forest and scrub, $70 \%$ of the catchment is in pasture, and $20 \%$ is covered by exotic forest (Page et al., 2001).

The removal of this indigenous forest cover initially by Maori settlement but later and more significantly European settlers has had a profound effect on the catchment's response to local climatic conditions. Presently the East Cape has a temperate maritime climate but can be subjected to weather and climatic extremes. Long periods of drought are common over the summer months. High magnitude precipitation events which cause widespread landsliding are either tropical cyclones/sub-tropical depressions from the north or associated with southerly frontal systems. There is a marked seasonal distribution of rainstorms/ cyclones from March to May as 40-45\% of the annual precipitation occurs between the months of May to August as low intensity events (Reid and Page, 2002). The eastward movement of a high pressure cell in the south Tasman Sea can intensify this situation bringing a cooler south-easterly airstream on to the area triggering precipitation or prolonging storms.

Annual rainfall rates increase moving away from the coast where annual rainfall is 1000 $\mathrm{mm}$ to $3000 \mathrm{~mm}$ in the north-west of the basin on the catchment divide (Smith, 1977). Wind flows from the north and north east tend to produce higher rainfall in the headwater catchments compared to the coastal low lands. But this topographically controlled rainfall distribution is less pronounced when high rainfall events come across 
the catchment from the south and south-east where there can be similar to significantly more rainfall at lower altitudes of the coastal hill country compared to the rest of the catchment (Hessell, 1980). This can have a marked effect on the catchment as the softer Tertiary landscape in the lower catchment is more landslide prone terrain. Extreme storms are responsible for the highest rainfall intensities on record in the Waipaoa catchment. The largest event in the recent times was Cyclone Bola in 1988 (a one in 100 year event) bringing between $600 \mathrm{~mm}$ to $900 \mathrm{~mm}$ of rainfall in 72 hours, causing extensive damage throughout the East Cape region. The location of slope failure is often related closely to this rainfall distribution especially with the localised occurrence of these extreme rainfall events.

\subsection{Land Systems Classification}

A large scale landform analysis of the entire Waipaoa catchment was carried out by the New Zealand Crown Research Institute Landcare Research - Manaaki Whenua Limited. Data was collated from the New Zealand Land Resource Inventory, a GIS based land resource data base of rock type, soil, slope, erosion and vegetation and the land use capability classification. From this, distinct land classes were defined primarily by lithology and classified as land systems. Lithology is assumed to directly influence landform and create a specific combination of erosion processes, drainage density, channel morphology and sediment supply capacity for each of the 16 land systems identified. There are only six land systems that experience landslide erosion covering $67 \%$ of the Waipaoa catchment. They are briefly described below in decreasing order of sediment supply: 
Table 3.1 Summary of the six landslide prone land systems in the Waipaoa Catchment. (data from Reid and Page, 2002; Page et al., 1999).

\begin{tabular}{|c|c|c|c|c|c|c|}
\hline Land System & Waingaromia & Te Arai & Makomako & Waihora & Wharerata & Wharekopae \\
\hline $\begin{array}{l}\text { Area }\left(\mathrm{km}^{2}\right)(\% \text { of } \\
\text { the Waipaoa } \\
\text { Catchment })\end{array}$ & $29(1.5 \%)$ & $513(23)$ & $138(6)$ & $78(3.5)$ & $278(12.5)$ & $448(20.5)$ \\
\hline $\begin{array}{l}\text { Bedrock } \\
\text { (Miocene - } \\
\text { Pliocene) }\end{array}$ & Mudstone & Mudstone & $\begin{array}{l}\text { Mudstone, } \\
\text { Sandstone }\end{array}$ & Siltstone & Sandstone & $\begin{array}{l}\text { Sandstone, } \\
\text { Mudstone }\end{array}$ \\
\hline $\begin{array}{l}\text { Prevalent } \\
\text { vegetation cover } \\
\text { (as at 1995) }\end{array}$ & Exotic forest & Pasture & Pasture & Pasture & Pasture & Pasture \\
\hline $\begin{array}{l}\text { Main erosion } \\
\text { processes }\end{array}$ & $\begin{array}{l}\text { Gully, earthflow } \\
\text { (deep), slump, } \\
\text { shallow } \\
\text { landslide }\end{array}$ & $\begin{array}{l}\text { Shallow } \\
\text { landslide, } \\
\text { earthflow, gully }\end{array}$ & $\begin{array}{l}\text { Shallow landslide, } \\
\text { gully, sheet }\end{array}$ & $\begin{array}{l}\text { Shallow landslide, } \\
\text { gully, sheet }\end{array}$ & $\begin{array}{l}\text { Shallow } \\
\text { landslide, sheet }\end{array}$ & $\begin{array}{l}\text { Shallow } \\
\text { landslide, } \\
\text { sheet, tunnel } \\
\text { gully }\end{array}$ \\
\hline Erosion extent & $\begin{array}{l}\text { Severe to very } \\
\text { severe }\end{array}$ & $\begin{array}{l}\text { Moderate to } \\
\text { severe }\end{array}$ & Slight to moderate & Moderate & Moderate & $\begin{array}{l}\text { Negligible to } \\
\text { slight }\end{array}$ \\
\hline $\begin{array}{l}\text { Rainfall failure } \\
\text { threshold }(\mathrm{mm})\end{array}$ & 200 & 150 & 200 & 150 & 150 & 125 \\
\hline
\end{tabular}




\subsection{Field Sites}

In August 2002 a high intensity rainfall event induced widespread shallow landsliding on the low lying coastal hills south of Gisborne. Off slope sediment delivery rates were determined from field estimates taken immediately after the event for 220 individual failures from three sites (Preston, 2008). These three sites selected by Preston (2008) represented homogeneous lithology and vegetation allowing for the analysis of other controlling variables on sediment delivery including slope properties and channel location. The single site Hinenui (described in section 3.5.1) is used in this study to predict sediment delivery ratios for individual failures (Figure 3.2).

The following three field sites selected for this thesis (described in sections 3.5.2 - 4) were chosen because of the contrasting morphometric properties and storm history which is expected to influence sediment delivery ratios. These three field sites are used to observe hillslope channel coupling at the contemporary time scale (Figure 3.2). Changes in the location of individual failures have a direct influence on sediment delivery ratios. The location of failures on the hillslope profile is assumed to be correlated to the stage of landscape relaxation since initial deforestation. Aerial photography is available across the three sites from the 1940s to 2004 . In these catchments an average of one multiple occurrence landslide event occurred every seven years. 


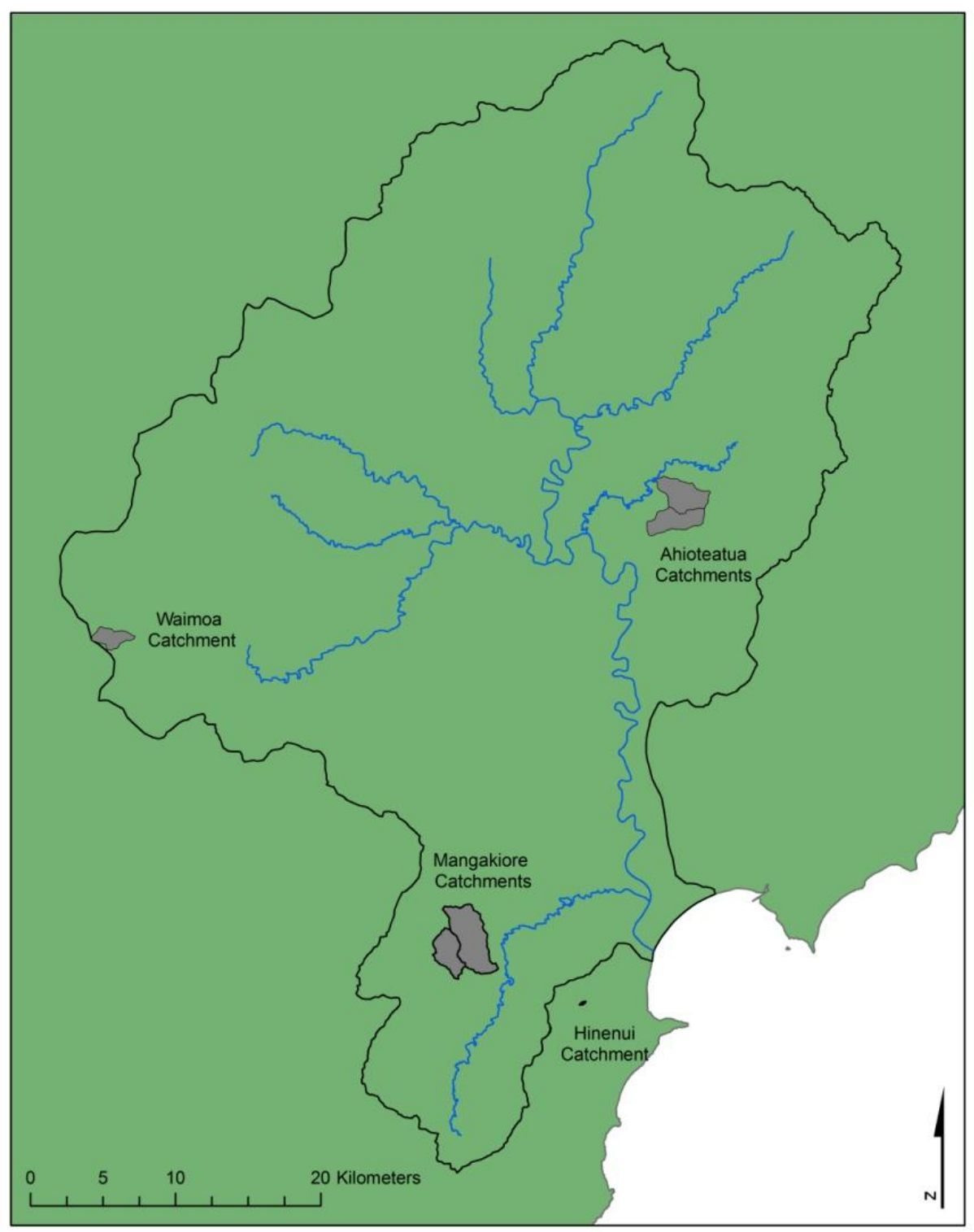

Figure 3.2 The location of the three field sites (Waimoa, Ahioteatua and Mangakiore) used in this thesis to identify spatial and temporal trends in sediment delivery ratios for earthflows. Also the proximity of the field site Hinenui where the multiple regression analysis will be undertaken to predict offslope sediment delivery for earthflows. 


\subsubsection{Hinenui}

Hinenui is the site used to develop the multiple regression model to predict sediment delivery ratios. It is a small hillslope catchment ( $~ 9$ ha) part of a hill country property 'Hinenui' which forms the catchment for the second main tributary to the Pakowhai stream, which is outside of the Waipaoa catchment to the south-east of the Te Arai valley. The area is predominantly underlain by Miocene undifferentiated massive and bedded, slightly calcareous mudstone. The small hillslope catchment has two valleys both of which are in-filled with undelivered sediment towards the top ridgeline and contain no permanent channels but evidence of ephemeral channels present during intense rainfall events. The hill slopes range from $15^{\circ}$ to $40^{\circ}$ and the thalwegs around $15^{\circ}$ to $10^{\circ}$ with a small fan at the base of the two valleys merging into the tributary's floodplain.

From the $5^{\text {th }}$ to the $7^{\text {th }}$ August 2002 this area experienced an extreme rainfall event with the highest rainfalls in the Gisborne area of $>300 \mathrm{~mm}$ recorded in the low coastal hills between Muriwai and the Te Arai valley. Consequently, this area experienced extensive landsliding with the hill country landowners noticing that the majority of the failures occurred towards the end of the storm following a 12 hour period of greatest rainfall intensity. Within this small hillslope catchment there were 71 shallow rainfall triggered earthflows causing widespread damage (Figure 3.3). These failures were very shallow where generally only the top soil layer mobilised as a fluid flow that ran down the hillslopes. Estimates of the sediment delivery from this 2002 storm event were determined by Preston (2008) and this empirical data is used in the prediction of sediment delivery ratios in this research. 


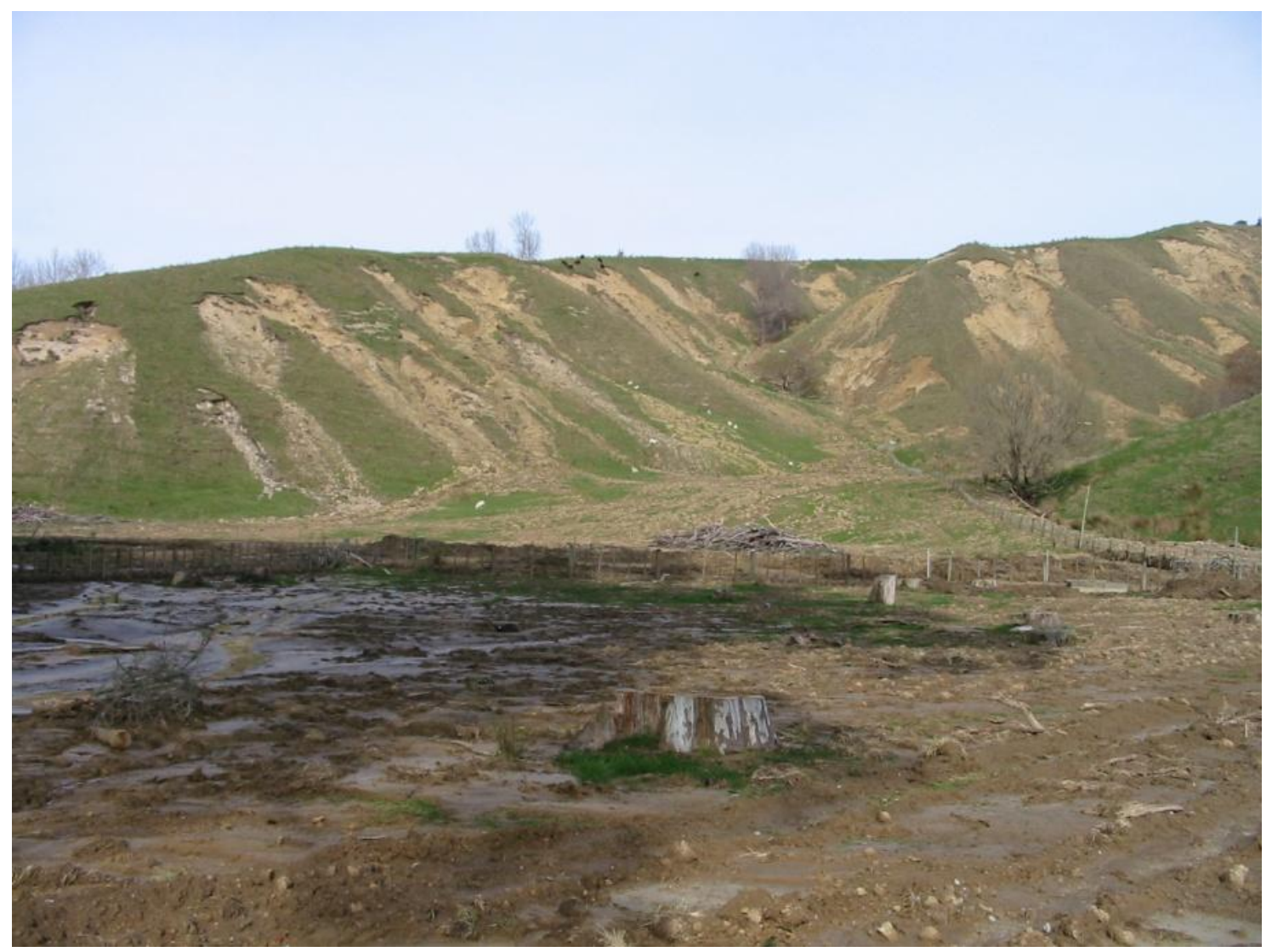

Figure 3.3 The Hinenui Catchment after the 2002 storm event. (Photo: N. Preston, 2002).

\subsubsection{Waimoa}

Waimoa is located within the Wharekopae land system forming the headwaters of the Wharekopae River in the western corner of the Waipaoa catchment. This field site is named after the nearby Waimoa Station where the small subcatchment ( 260 ha) used in this study is located. Originally due to the small size of the catchment two other larger catchments were also selected to the south-east. However, the aerial photography obtained for this thesis did not provide adequate coverage for these catchments and therefore they were not analysed. Underlying geology is massive and bedded Miocene mudstone with intercalated beds of fine grained sandstone (Mazengarb and Speden, 2000). Soil depth within the Wharekopae land system is typically over $100 \mathrm{~cm}$ (Page et 
al, 1999) with a rhyolitic tephra mantle. The hillslopes are strongly rolling with no clearly incised channels and the slope difference between the hillslopes and the channel is minimal. In Catchment A the slopes are predominantly under $20^{\circ}$ with some narrow ridges over $30^{\circ}$ and has considerably high drainage density. The rainfall threshold required for individual failures in the Wharekopae land system is $125 \mathrm{~mm}$ in a 24 hour period (Page et al., 1999). Using a 90 year rainfall record there have been 8 multiple occurrence landslide events assumed to have affected the Waimoa catchment and the average total rainfall for these events is $273 \mathrm{~mm}$. Average landslide frequency within the Wharekopae land system is 8 failures per $\mathrm{km}^{2}$ per year on pasture (Reid and Page, 2002).

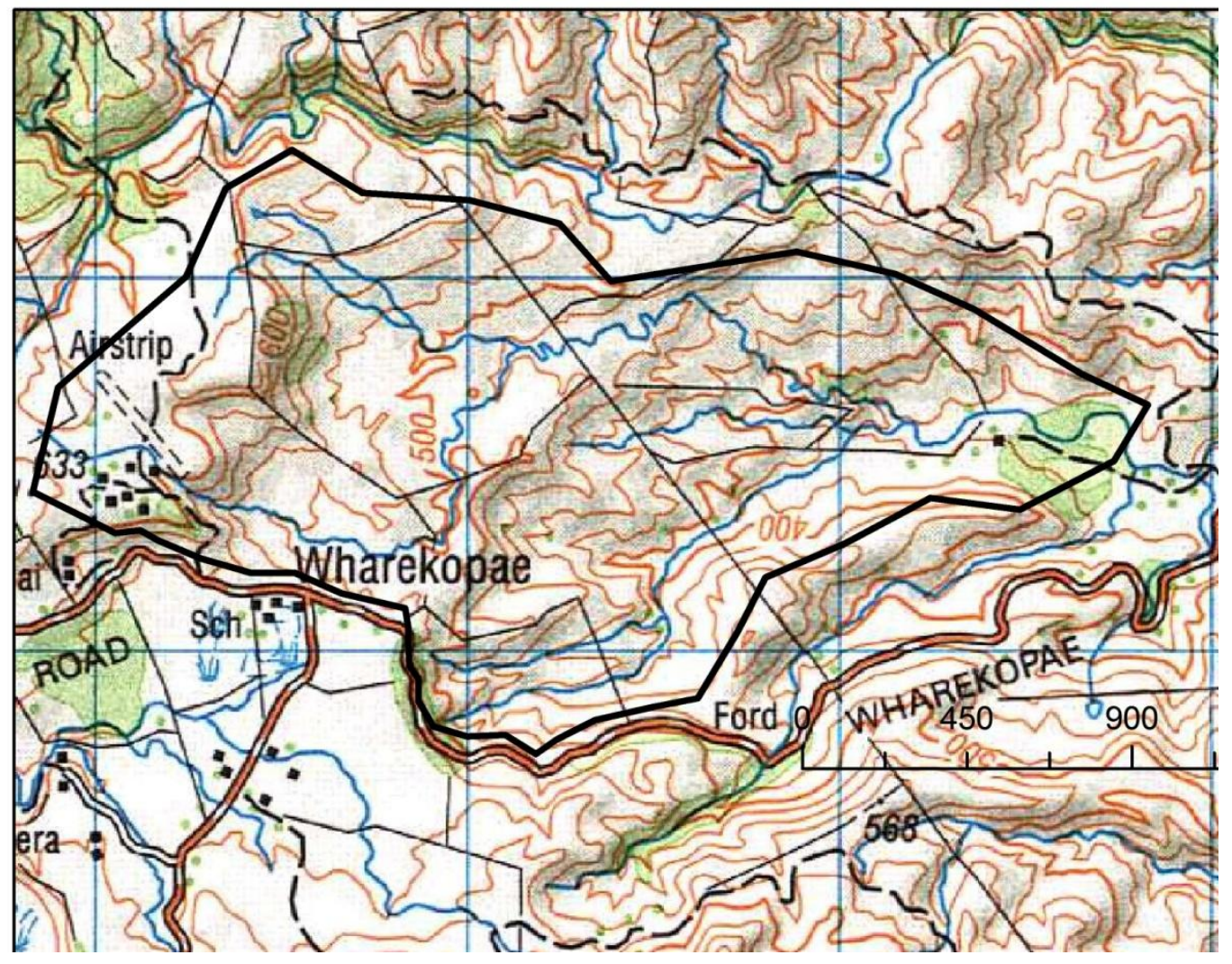

Figure 3.4 Topographic map of the Waimoa Catchment. (Sourced from Topographic Map 260, X17, Crown Copyright Reserved). 


\subsubsection{Ahioteatua}

Ahioteatua is located within the Waihora land system in the eastern side of the Waipaoa catchment. The field site is named after the Ahioteatua Trig Station located at the boundary of the two small subcatchments $(\sim 560$ ha and $\sim 480$ ha). The underlying geology is early Pliocene mudstone and bedded sandstone and mudstone throughout the two catchments with mid Miocene massive and bedded mudstone with intercalated beds of fine grained sandstone at the outlets of both catchments (Mazengarb and Speden, 2000). On uneroded hillslopes soil depth is up to $100 \mathrm{~cm}$ in the Waihora land system (Page et al., 1999). The slopes are steep, planar and long with narrow ridge crests. Within both catchments the slopes are predominantly $>30^{\circ}$ with long straight slopes leading directly into incised channels. Catchment $\mathrm{A}$ is long and narrow where only the northern half of the catchment has drainage channels off the main stream, whereas Catchment B has more evenly distributed drainage. Catchment B drains directly into the Waihora River whereas Catchment A drains further south into the Mangaoai Stream, a tributary to the Waipaoa River. The rainfall threshold required for individual failures in the Waihora land system is $150 \mathrm{~mm}$ of rain in a 24 hour period (Page et al., 1999). Using a 90 year rainfall record there have been 12 multiple occurrence landslide events and the average rainfall magnitude for these events is $263 \mathrm{~mm}$. Average landslide frequency on pasture in the Waihora landsystem is 18 failures per $\mathrm{km}^{2}$ per year (Reid and Page, 2002). 


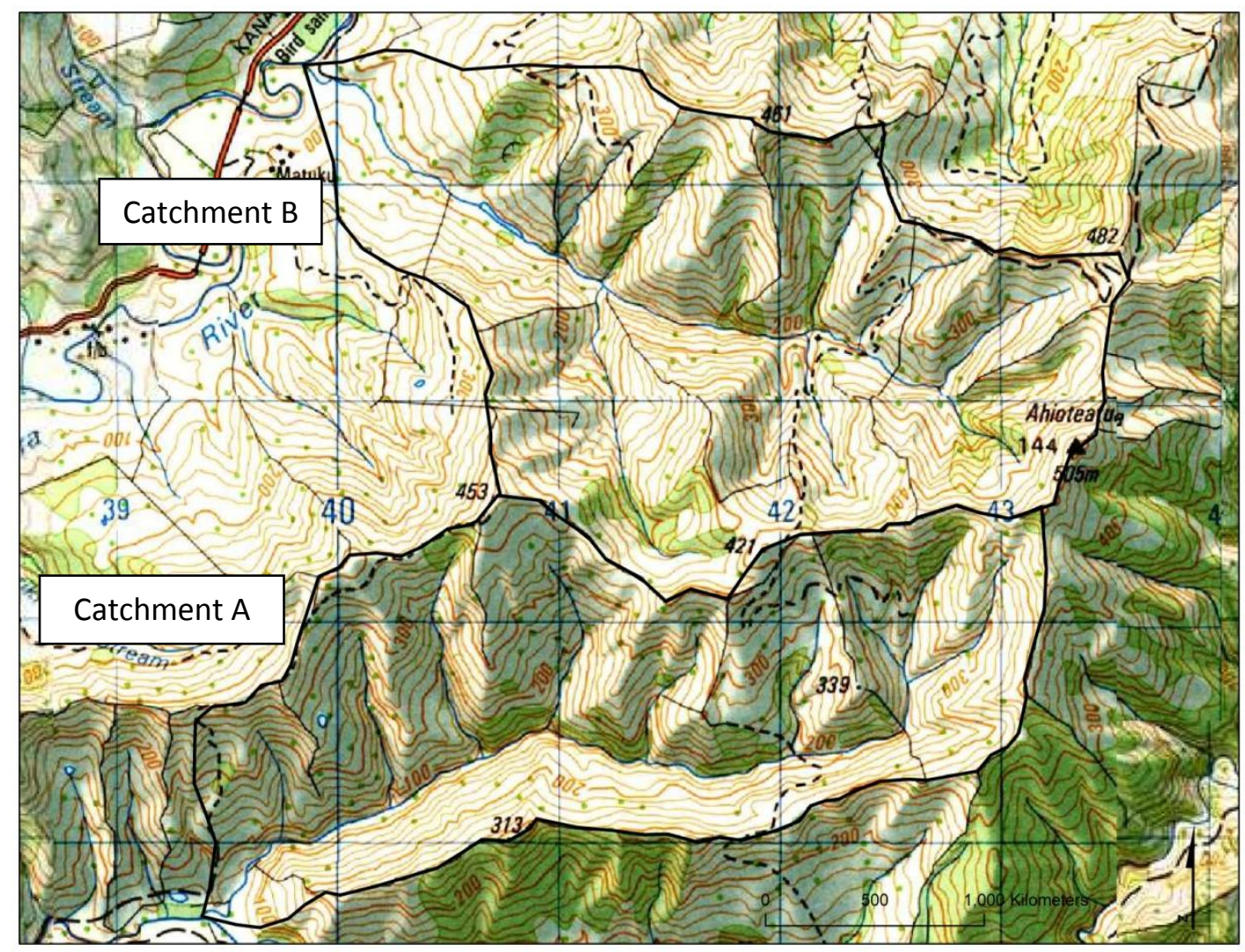

Figure 3.5 Topogaphic map of the Ahioteatua Catchments. (Sourced from Topographic Map 260, Y17, Crown Copyright Reserved).

\subsubsection{Mangakiore Field Site}

Mangakiore is located within the Te Arai land system in the southern part of the Waipaoa catchment. This field site is named after Mangakiore Station where two of the small sub-catchments ( 930 ha and $\sim 40$ ha) used in this study are located. The underlying geology is uniform between the two catchments with massive and bedded Miocene mudstone and intercalated beds of fine grained sandstone (Mazengarb and Speden, 2000). The mudstone weathers quickly frittering with surface exposure and exhibits a closely spaced fracture pattern. Typical soil depth varies within the Te Arai land system with $100 \mathrm{~cm}$ on the ridge tops and stable slopes reducing to $0-30 \mathrm{~cm}$ on recently eroded slopes (Page et al., 1999). The hillslopes have various shapes with complex pattern of ridges and spurs but generally long smooth slopes run directly into 
the narrow incised ephemeral channels. The main channel is incised in the upper half of the catchments but there is significant infilling with the development of small colluvial footslopes towards the outlet. Slopes range from $\sim 30^{\circ}$ to $40^{\circ}$ in the upper half of the catchments to $\sim 20^{\circ}$ to $30^{\circ}$ in the lower half with channel slope below $15^{\circ}$. Both Catchments A and B drain into the Waimata Stream a tributary to the Te Arai River. The rainfall threshold required for individual failures in the Te Arai land system is 150 $\mathrm{mm}$ of rain in a 24 hour period (Page et al., 1999). Using an 80 year rainfall record there have been 9 multiple occurrence landslide events with the average event being 293 $\mathrm{mm}$ of rain. Average landslide frequency on pasture is 28 failures per $\mathrm{km}^{2}$ per year in the Te Arai land system (Reid and Page, 2002). 


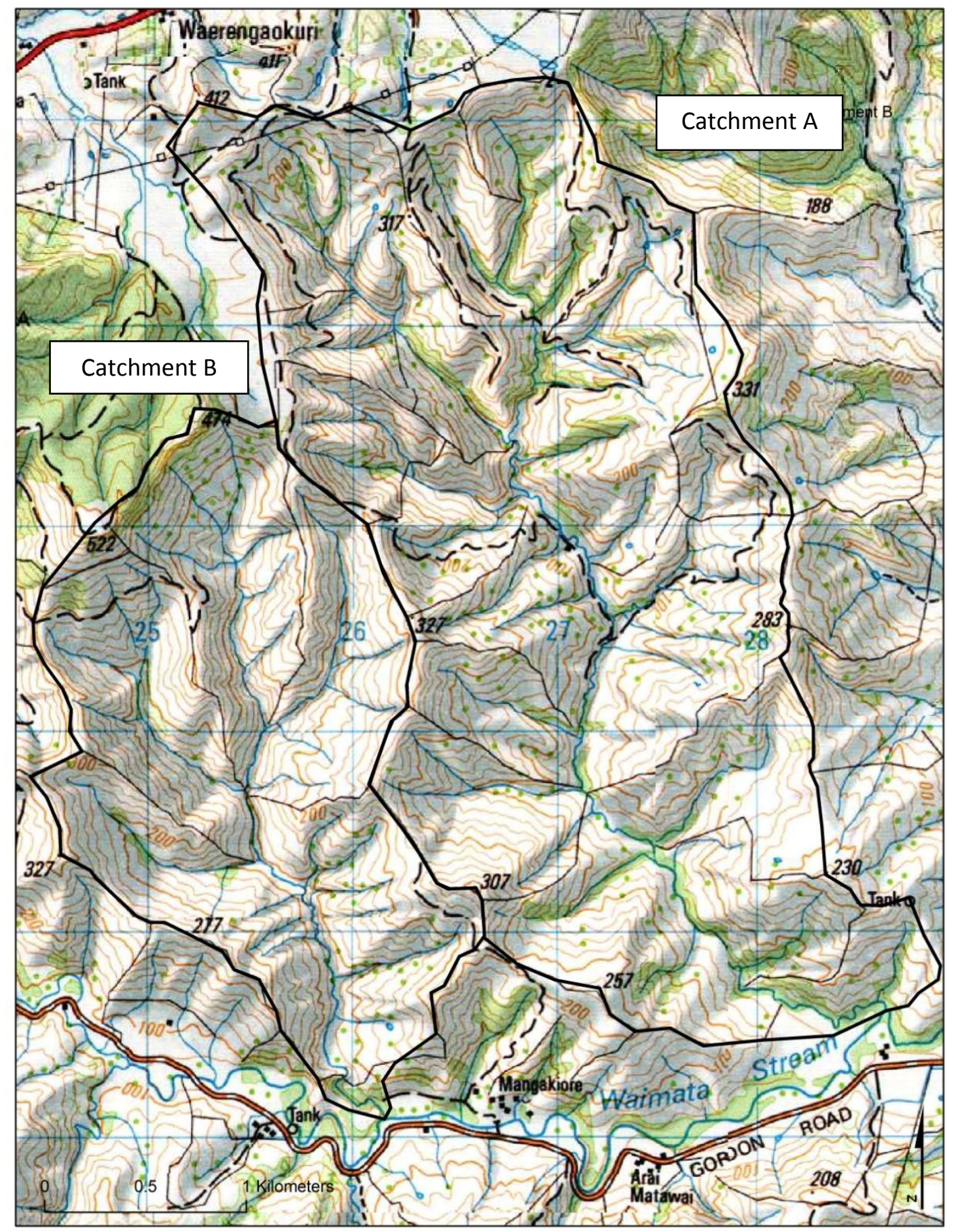

Figure 3.6 Topographic map of the Mangakiore Catchments. (Sourced from Topographic Map 260, X18, Crown Copyright Reserved). 


\section{Chapter Four: Sediment Delivery Modelling}

\subsection{Introduction}

This chapter introduces the methodology used to derive the catchment sediment delivery ratios for earthflows in five catchments within the Waipaoa catchment. Data characterising the catchments were derived from three main sources: digital elevation models, aerial photography and field surveys. For each site the data source and mode of further analysis were chosen according to their accuracy, suitability and availability. Nearly the entire analysis of data was undertaken in a GIS environment (ArcGIS version 9.3) with all layers registered in the 1949 New Zealand Map Grid projection system. The first part of this chapter focuses on the development of a multiple regression equation to predict sediment delivery ratios for individual failures. The second part of this chapter focuses on the overall techniques used to determine the changes in connectivity and subsequent sediment delivery ratios throughout areas of the Waiapoa catchment. The results of the empirical modelling of sediment delivery ratios and the application of these results to determine catchment sediment delivery ratios are given in Chapter Five. Further discussion on both modelling sediment delivery ratios and identifying spatial and temporal patterns is provided in Chapter Six.

A flow diagram is given below providing a clear outline to the structure of the methodology of this thesis and the configuration of this chapter (Figure 4.1). 


\subsection{Sediment Delivery Ratio Multiple Regression}

\begin{tabular}{|c|c|c|}
\hline $\begin{array}{l}\frac{\text { Morphometric }}{\text { Properties }} \\
\text {-Slope Angle }\end{array}$ & $\begin{array}{l}\text { Multiple regression analysis } \\
\text { of SDR based on } \\
\text { morphometric, landslide }\end{array}$ & $\begin{array}{l}\text { Also develop } \\
\text { regression } \\
\text { equations for }\end{array}$ \\
\hline Landslide Properties & & runout length \\
\hline -Scar Location & $\downarrow$ & and scar length \\
\hline -Debris Tail Runout & Develop regression & \\
\hline$\frac{\text { Soil Properties }}{- \text { Liquid Limit }}$ & $\begin{array}{l}\text { sediment delivery ratio for } \\
\text { an individual failure }\end{array}$ & \\
\hline
\end{tabular}

Figure 4.1 Flow diagrams of the methodology of this thesis and also an overview of the structure of this chapter. Section 4.2 describes the techniques used for multiple regression analysis of off-slope sediment delivery. Section 4.3 describes the techniques used to map the earthflow scars off aerial photography and determine their connectivity to the fluvial network. From this sediment delivery ratios are applied to individual scars to determine overall catchment sediment delivery and identify spatial and temporal patterns to these values.

\subsection{Spatial and Temporal Trends in Sediment Delivery Ratios (SDR)}

$\frac{\text { For each catchment and sequential }}{\text { set of aerial photography }}$

i)

\section{Digitise from the Aerial Photography i) Landslide Scars}

-determine scar area in GIS -derived scar volume using Page et al. (1999) scar depths

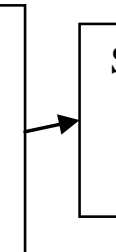

Separate each catchment into five overlapping nested sub-catchments

For each of these:

\begin{tabular}{|c|c|}
\hline $\begin{array}{l}\text { Derive the spatial } \\
\text { pattern in SDR as } \\
\text { catchment size } \\
\quad \text { increases }\end{array}$ & $\begin{array}{l}\quad \text { Identify Spatial Trends } \\
\text { i) Compare the SDR values of each } \\
\text { nested sub-catchment for each } \\
\text { individual field site }\end{array}$ \\
\hline $\begin{array}{c}\text { Derive the temporal } \\
\text { pattern in SDR as } \\
\text { the catchment } \\
\text { evolves }\end{array}$ & $\begin{array}{l}\quad \text { Identify Temporal Trends } \\
\text { i) Compare the SDR values of the } \\
\text { entire catchment (largest nested } \\
\text { catchment) for the time series used for } \\
\text { each individual field site }\end{array}$ \\
\hline
\end{tabular}

\section{Determine SDR:}

i) Determine SDR of connected scars from Hinenui regression equation ii) Determine total volume of delivered sediment from these scars

iii) Assume 0\% SDR for disconnected scars

iv) The catchment SDR is the total volume of delivered sediment as a proportion of the total volume of generated sediment

\section{Scar Promixity:}

i) Buffer the fluvial network in $10 \mathrm{~m}$ intervals

ii) Determine the total length of the scar and debris tail (using scar length and runout equations derived from the multiple regression analysis at Hinenui)

\section{Determine Connectivity:}

i) Where the total length of the scar and debris tail is greater than the length of the buffered distance to the fluvial network then the scar is connected as it will intersect the fluvial channel ii) If the total length of the scar is less than the buffered distance from the fluvial network then the scar is considered disconnected as it will not intersect a fluvial channel 


\subsection{Sediment Delivery Ratio Multiple Regression}

The methodologies outlined below relate to developing a simple multiple regression equation to predict sediment delivery ratios for individual failures outlined in Aim One. This model is calibrated on the Hinenui catchment with sediment delivery ratios from the 2002 storm event determined in the field by Preston (2008). Flow diagrams for the GIS analysis and Visual Basic scripts are given in Appendix A. The variables of scar volume, scar length, runout slope angle, runout slope curvature, change in elevation of the runout path, and distance between the scar and fluvial channel were used in the regression analysis to develop a multiple regression model to predict sediment delivery ratios.

\subsubsection{Morphometic and Landslide Properties}

Preston (2008) presented sediment delivery ratios for earthflow failures at Hinenui in 2002. The 71 scars at Hinenui were identifiable on the 2002 aerial photo and from this a vector polygon layer of these scars was created. The low resolution 2002 aerial photo was taken immediately after the storm event clearly showing scars and debris tails. This image was rectified against a high resolution orthorectified 2007 photo. There was an 8.0 residual error for the rectification of the 2002 photo. This is a measure of the error between the control points used to transform the photo (i.e. the difference between where the point ended up representing opposed to the actual location that was specified as the image was rectified). The scar polygons were derived polygons from the visible bare soil in the 2002 aerial photo. This landslide scar layer was created by identifying bare soil values by adding the aerial photo raster layer as one spectral band and then using <SPATIAL ANALYSIS> <RECLASSIFY> to reclassify the bare soil value. This layer was then converted from raster to vector using the <SPATIAL ANALYSIS> $<$ CONVERT $>$ Raster to Features using the option of generalizing lines. This vector layer was then edited to remove non-landslide derived bare soil polygons and separate polygons for multiple scars. Scar length was determined from the estimated down (maximum slope) axis. Scar area was derived in ArcGIS and the approximate volume of 
each of the landslide scars was determined by using a universal depth of $0.5 \mathrm{~m}$. This is lower than the average scar depth determined by Page et al., (1999) for Te Arai land system for Cyclone Bola which is $0.76 \mathrm{~m}$. The Te Arai land system is adjacent to Hinenui and has similar underlying lithology but steeper and longer slopes. From field estimations of the 2002 scars at Hinenui, the depth value of $0.76 \mathrm{~m}$ was considered a slight overestimation.

A field survey was also carried out for the small hillslope catchment at Hinenui in April 2008. The site was surveyed using a Trimble S6 Servo-driven Total Station (S6) with reflector-less (terrain scanning) capability. A total of 23 stations (including the base station) were set up throughout the site, as while the $\mathrm{S} 6$ had a range limit of $400 \mathrm{~m}$, this allowed for higher resolution scanning necessitated by the irregular surface of the hillslopes. Most of the stations were located in the thalwegs of each of the two valleys with two stations set on the ridgelines (Figure 4.2). Elevation with easting and northing coordinates was taken as points in $4 \mathrm{~m}$ intervals in the automatic format across squares set manually. The interval was set at $4 \mathrm{~m}$ to be as accurate as possible within a realistic timeframe. The Trimble R8 Real Time Kinematic (RTK) GPS was used to collect base station data for the S6 and was used in areas where the S6 was limited by trees, topography or distance. The RTK was also useful in identifying clumping of trees to edit distorted points from the S6 and along the ridge line to define the extent of the site. The points collected from both the S6 and RTK were input into Trimble Geomatics Office to read and process data. These data points were screened and translated into ASCII and a digital elevation model (DEM) was constructed using ESRI Arc/Info GIS software with grid interpretation of elevation. Each pixel in the DEM of the catchment represents $1 \mathrm{~m}$ by $1 \mathrm{~m}$, resulting in a high resolution representation. 

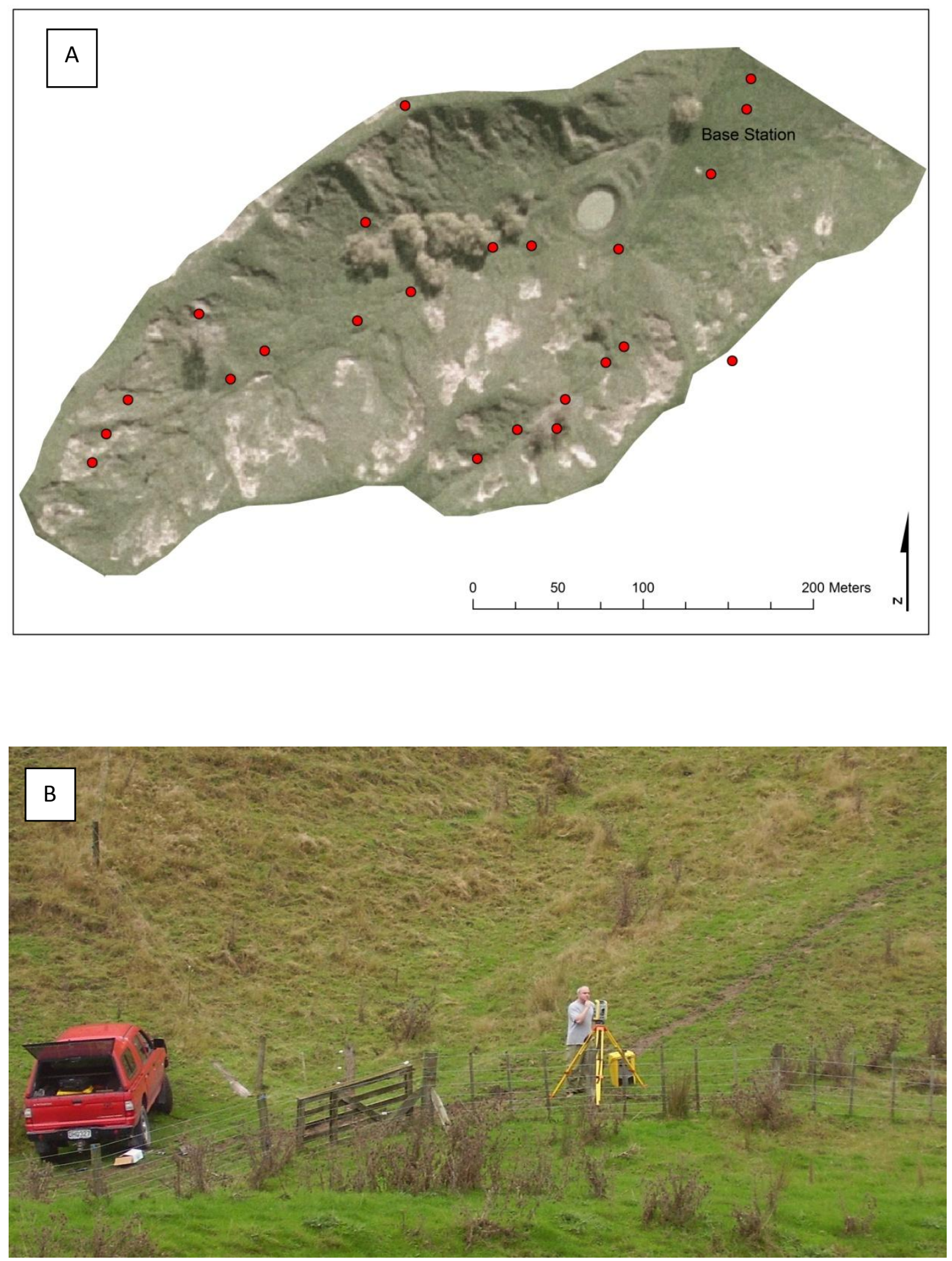

Figure 4.2 A) S6 stations in the Hinenui catchment. B) S6 in use by M. Henderson scanning the Hinenui catchment. (Photo: K Jones, 2008). 
There is no permanent waterway though the hillslope catchment but Preston (2008) found strong evidence of ephemeral channels in topographic convergences present during heavy rainfall events. The likely location of these drainage pathways was derived digitally through ArcMap from the DEM of the Hinenui site. Digitally the drainage network is delineated using the <SPATIAL ANALYST> <HYDROLOGY> tools. The upslope extent of the fluvial network was estimated from field evidence of the ephemeral channels at Hinenui (Figure 4.3).

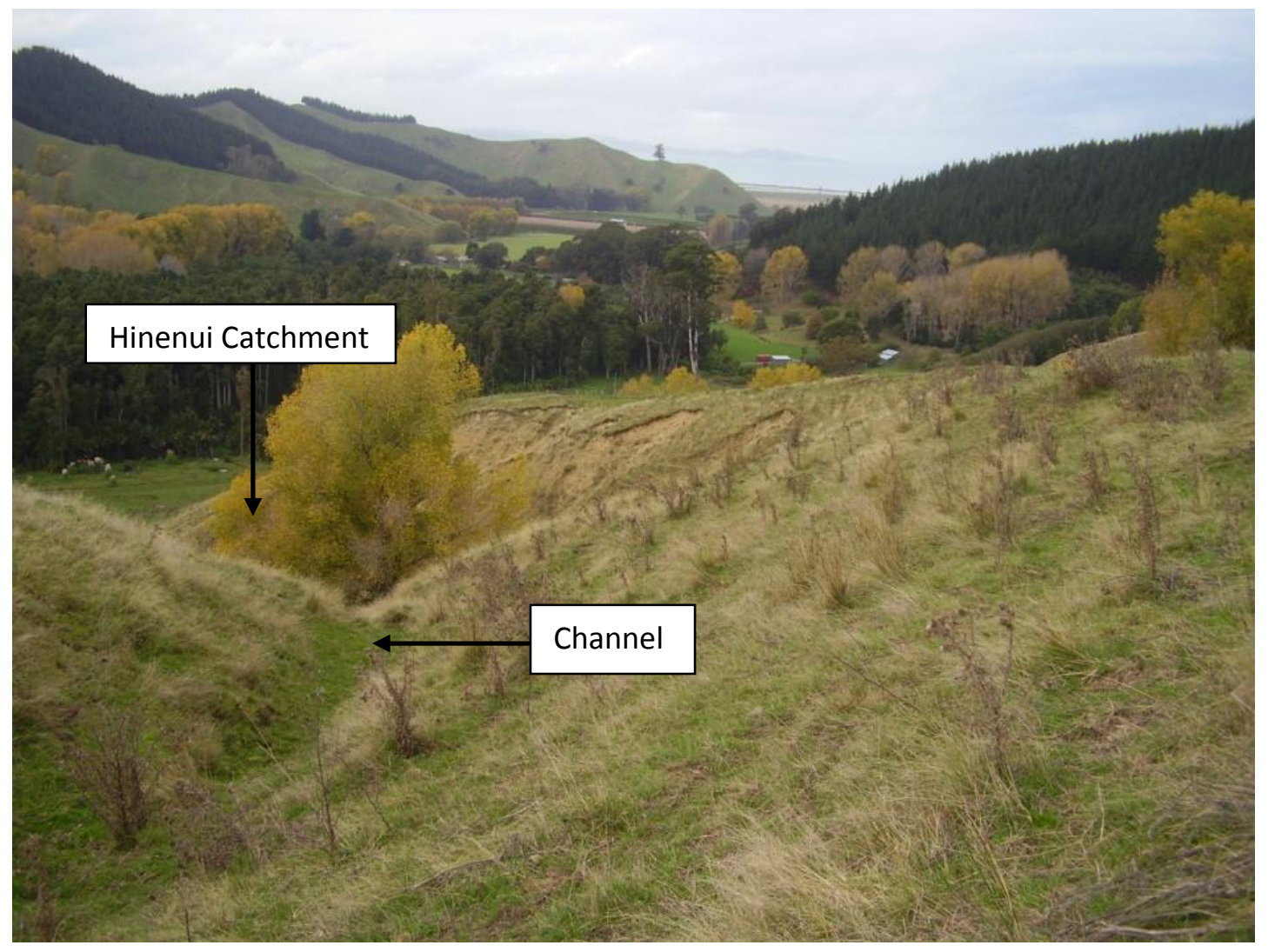

Figure 4.3 Evidence of channel formation at the top of the Hinenui catchment. (Photo: K Jones, 2008).

The earthflow debris tails were derived digitally for each earthflow from the $1 \mathrm{~m}$ DEM created for the field site. Runout paths were defined from the base of the surface rupture of the scar and flowed downslope until either intersecting fluvial channel (if the scar 
delivered sediment) or exhaustion terminated the flow. Runout paths were derived in ArcGIS for each individual landslide scar using the $<$ STEEPEST PATH $>$ tool under <3D ANALYST> to generate a polyline layer which represents the path a ball would take if released from the centre of the base of the landslide scar. This path was converted to 3D in $\langle\mathrm{CONVERT}\rangle$. The Visual Basic scripts shape_Return3D_Length and PolylineZ_GetSlope (sourced from www.ian-ko.com/free/free_arcgis.htm) were used to determine the 3D length and slope angle of the runout path for each individual failure. Where the earthflows failed to deliver sediment off-slope the terminus of the debris tail was estimated from the 2002 aerial photo. Dymond et al. (1999) suggests that steeper slopes tend to have longer runout distances as the tail depth is small and sediment is depleted slowly as the mass flows downslope. In contrast, on more gentle slopes the runout distances are shorter as sediment is depleted quickly due to the lower transport capacity associated with lower slope angle. Therefore, higher slope angles are expected to be correlated with higher sediment delivery from the landslides which occur on these slopes. Another Visual Basic script was written to determine the start and end point elevation of the runout path and therefore the change in elevation. This change in elevation of the runout was used as a surrogate for the potential energy of the flow. The slope angle, length and elevation change of each runout path was then compared to the sediment delivery for each earthflow.

The second morphological property of curvature is expected to have a strong influence on sediment delivery so is quantified for each earthflow scar runout path. Slope curvature is again derived from the DEM in GIS with <SURFACE ANALYSIS> <CURVATURE>. It identifies the curvature for each individual cell in a raster surface including plan and profile curvature. While plan curvature influences the convergence and divergence of runoff, profile curvature is assumed to have a higher influence on sediment delivery. Profile curvature affects the acceleration and deceleration of runoff and this also applies to the debris tail runout. A lower resolution $25 \mathrm{~m}$ DEM (available on the Victoria University Database and produced by GeographX NZ Ltd with elevation data from Land Information New Zealand) was used to determine curvature. The higher resolution $1 \mathrm{~m}$ DEM was not used due the confusing effect of detailed microtopography 


\subsubsection{Soil Properties}

Soil samples were collected for determining the liquid limit of the soil within the small hillslope catchment in Hinenui. Soil samples were chosen from three different types of regolith and 8-10 locations for each resulting in 26 soil samples for the catchment (Figure 4.4). These 26 samples have been assumed to be representative of soil across the whole Hinenui catchment because the field site is small ( $\sim 9 \mathrm{ha})$. The three types of regolith sampled were:

1. Undisturbed regolith which usually appeared on the ridges.

2. Recently Disturbed regolith which was debris material from older landslides which was re-vegetated, indicating that these landslides predated the 2002 storm event.

3. Disturbed regolith which failed in the 2002 storm event.

Liquid Limit was determined for all of the soil samples using the Cone Penetrometer technique based on NZ Standards NZS 4402: 1986 Test 2.5. While other techniques are available for determining liquid limit the cone penetrometer test is relatively straightforward and less subject to operator error. The procedure was repeated twice for each soil sample and results were combined for all samples to give an average liquid limit for each of the three sampling zones. Results of the liquid limit testing are given in Appendix B. 


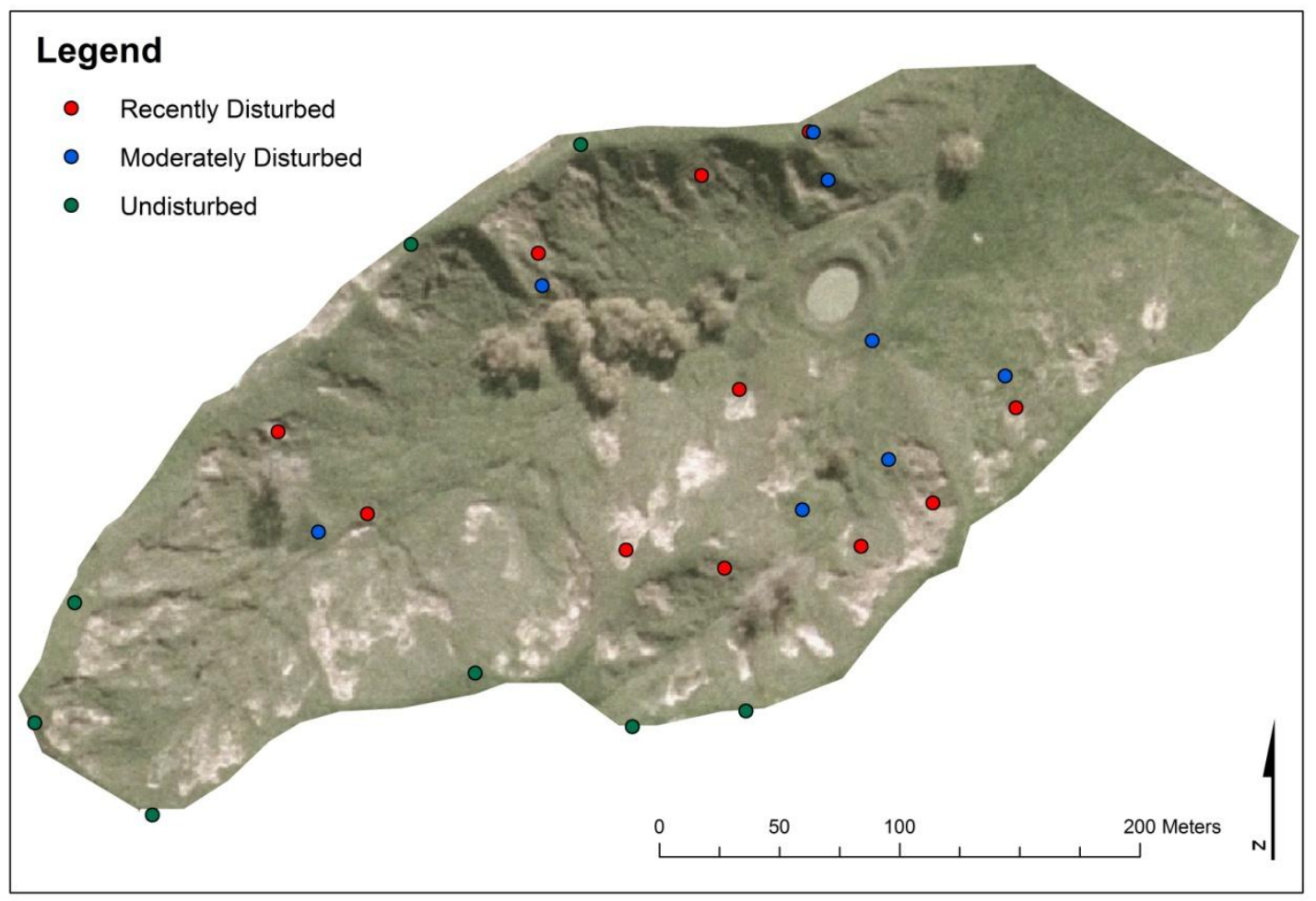

Figure 4.4 Soil sample locations in the Hinenui.

\subsubsection{Multiple Regression Analysis}

Frequency distributions were examined for each variable and the coefficients of determination between variables were determined. Stepwise multiple regressions were undertaken in Statgraphics Centurion XV Version 15.2.12 incorporating independent variables physically related to sediment delivery to develop a predictive model for sediment delivery ratios for earthflows.

Regression analysis was also repeated to model scar length and debris tail runout path. Scar length is easily derived within GIS by determining the axis length of the scar between the points of highest and lowest elevation. However, the DEM acquired for the other field sites used in this thesis has resolution of $25 \mathrm{~m}$ by $25 \mathrm{~m}$. This means that that scar length axis must be longer than $25 \mathrm{~m}$ in order that the scar polygon covers two DEM pixels to assess the elevation difference between the crown and base of the scar. However, in Page et al., (1999) the average scar length for Cyclone Bola was less than $25 \mathrm{~m}$ at the Wharekopae, Waihora and Te Arai land systems. Therefore, a regression 
equation was developed to predict scar length at these locations. Regression analysis was also undertaken to develop a model for runout length. While there are suitable regression equations already developed to predict runout distances for earthflows (e.g. Corominas et al., 1991; Crozier, 1996), a more site specific regression equation for the Waipaoa catchment was developed. This equation also allows for the inclusion of slope angle which is important when this equation will be used at sites of varying slope angles.

\subsection{Spatial and Temporal Trends in Sediment Delivery}

\subsubsection{Mapping Landslides and Channel Density}

Aerial photography is a valuable resource to view past landscape conditions, with detailed imagery available for New Zealand since the 1930s. For this research, aerial photos were obtained for the three study sites of Te Arai, Waihora and Wharekopae (Table 4.1). Each set of aerial photography represents a different stage in the catchments' response since deforestation and displays the recent landslide scars attributed to the local storm history.

All the aerial photos were scanned in black and white (with the exception of the 2004 colour photos) with a resolution of 1200 dpi to create individual JPEG files. After being cropped in PICTURE MANAGER to remove the frames, each time set of photography was stitched together in COREL DRAW to create one continuous photo for each time set. No GPS co-ordinates were collected due to the rural location of the three field sites which meant that there were limited potential reference control points identifiable both in the aerial photo and in the field. 
Table 4.1 Aerial photography for the three field sites of Waimoa, Ahioteatua, and Mangakiore.

\begin{tabular}{|c|c|c|c|c|c|}
\hline \multicolumn{2}{|c|}{ Waimoa } & \multicolumn{2}{c|}{ Ahioteatua } & \multicolumn{2}{c|}{ Mangakiore } \\
\hline Date & Scale & Date & Scale & Date & Scale \\
\hline & & $14 / 3 / 1943$ & $1: 12500$ & & \\
\hline & & & & $2 / 3 / 1949$ & $1: 12500$ \\
\hline $1 / 4 / 1952$ & $1: 12500$ & & & & \\
\hline & & $18 / 11 / 1957$ & $1: 12500$ & & \\
\hline $27 / 9 / 1965$ & $1: 18000$ & & & $23 / 9 / 1965$ & $1: 1800$ \\
\hline & & $19 / 9 / 1969$ & $1: 18000$ & & \\
\hline $19 / 12 / 1974$ & $1: 19500$ & & & $26 / 8 / 1974$ & $1: 18700$ \\
\hline & & & & & \\
\hline $26 / 9 / 1980$ & $1: 25000$ & & & & \\
\hline & & $14 / 11 / 1982$ & $1: 27000$ & & \\
\hline $9 / 12 / 1984$ & $1: 25000$ & & & & \\
\hline & & $22 / 3 / 1988$ & $1: 27000$ & $28 / 3 / 1988$ & $1: 25000$ \\
\hline $15 / 4 / 2004$ & $1: 40000$ & $15 / 4 / 2004$ & $1: 4000$ & $10 / 4 / 2004$ & $1: 40000$ \\
\hline
\end{tabular}

Therefore a 1:50 000 topographic map was imported into ArcGIS in a raster format with the New Zealand Map Grid projection (NZMG) co-ordinate system. These maps were used as the base to rectify the aerial photos. A minimum of 10 points were used for the referencing of each set of aerial photography. These points were as evenly spaced as possible with features common to most if not all of the photographs using clearly identifiable reference points in the photography. Due to the rural nature of the photography the exact locations of many of the reference points were open to interpretation. Roads and other stationary references were usually limited to only one side or corner of the photography, meaning points such as stream junctions, ridgelines and vegetated areas were used for the other areas of the photography. Photos were 
rectified in $1^{\text {st }}$ order so the distortion of the photography matched features between photos. Finally, shape files of the catchment outline and stream network were digitised from the topographic map and compared to the georeferenced images to check for alignment in the photography (Figure $4.5 \mathrm{~A}-\mathrm{E}$ ). This has resulted in a large residual error in the photography with RMS errors ranging from 30 to 73. In addition, the 1:50 000 topographic map which the photography is referenced against is only accurate to within $100 \mathrm{~m}$. The combination of the above is the greatest sources of error on the aerial photography. Any remaining geometric distortion of the aerial photography is considered less than the error margin given above.

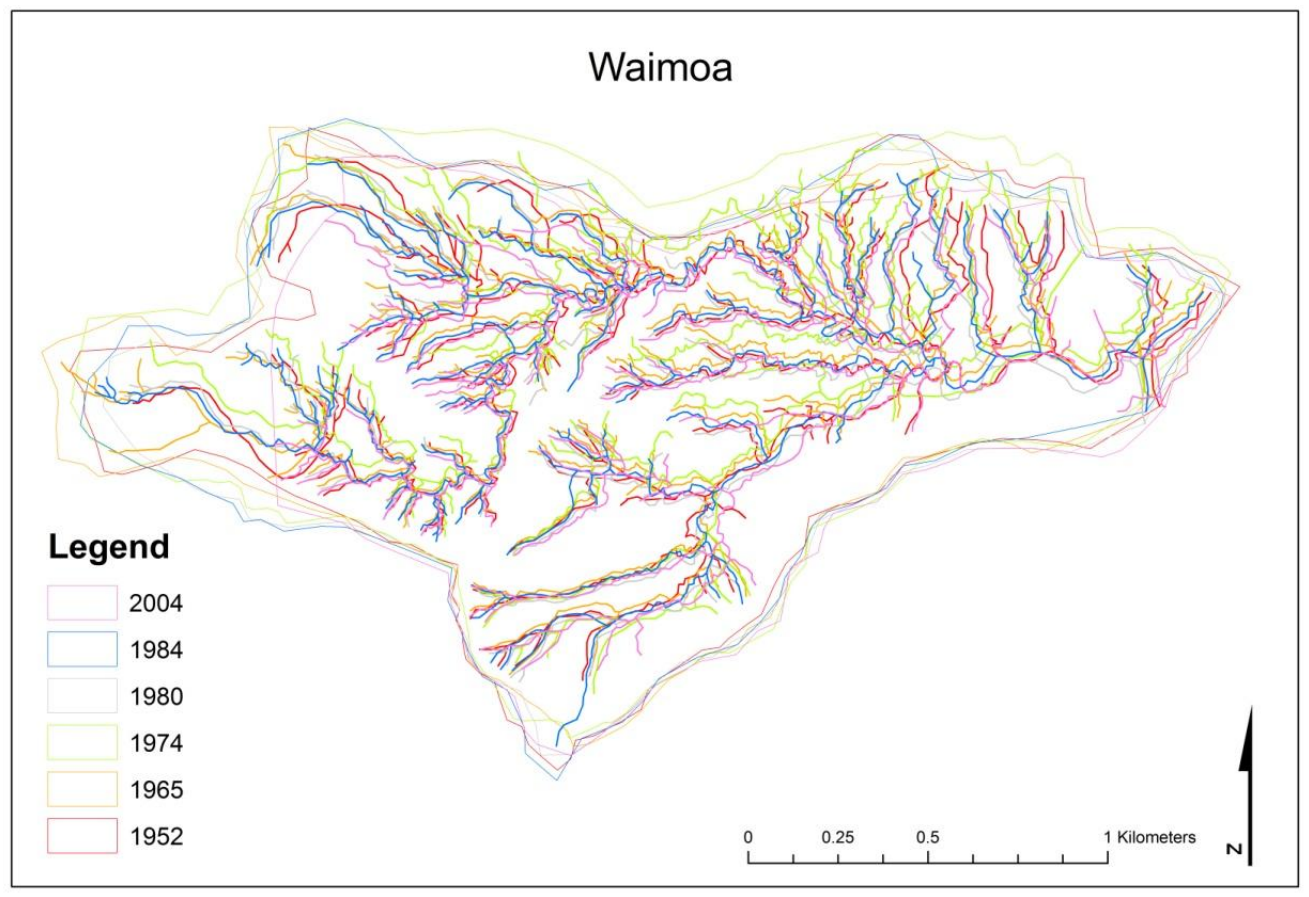

Figure 4.5 A) Misalignment of catchment boundaries and channels as digitised from images of the Waimoa catchment. 

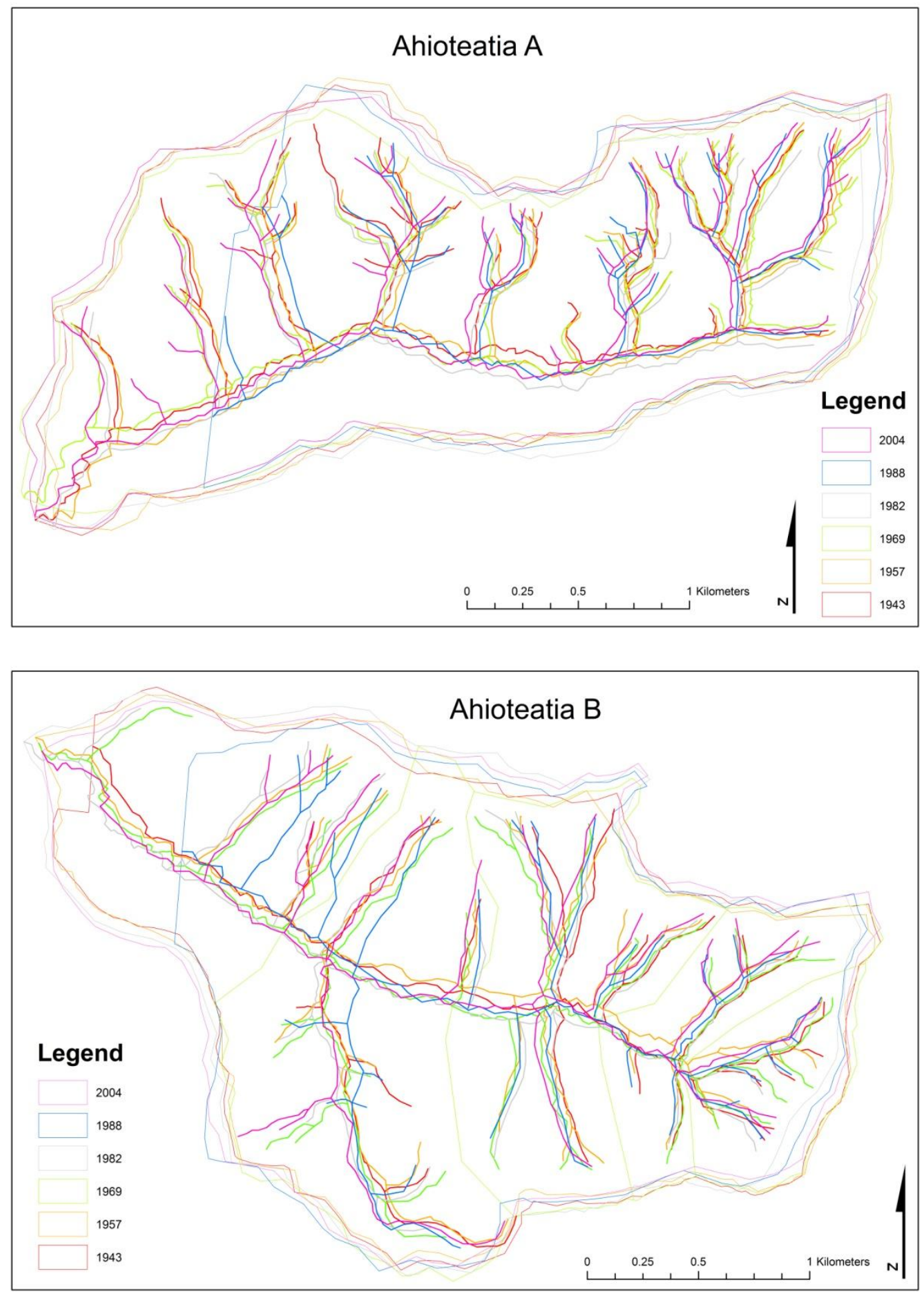

Figure 4.5 B \& C) Misalignment of catchment boundaries and channels as digitised from images of the Ahioteatua catchments. 

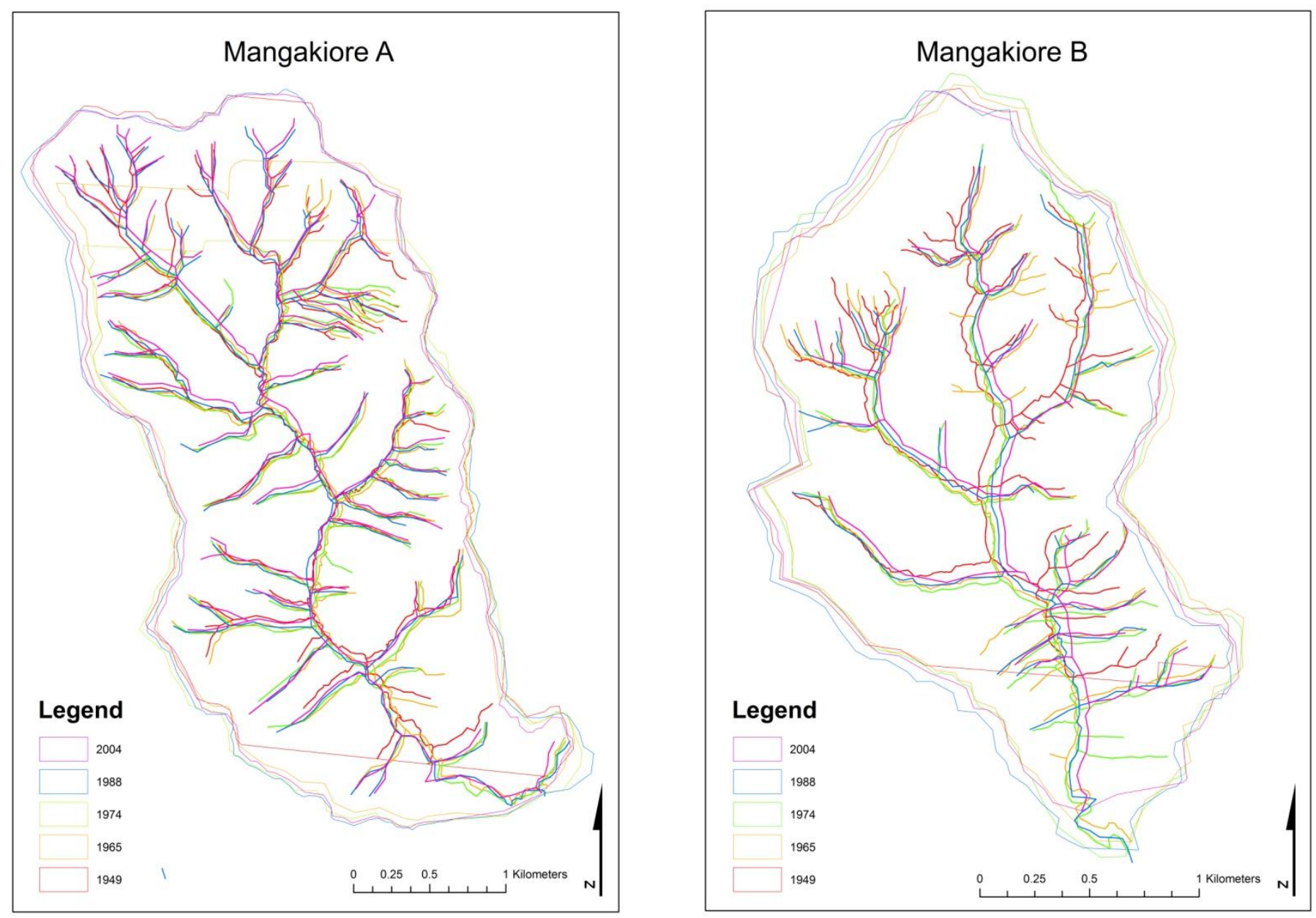

Figure 4.5 D \& E) Misalignment of catchment boundaries and channels as digitised from images of the Mangakiore catchments. 
While the georeferencing errors for each photo are considered to be within a broadly similar range, there still remains the issue of comparing and matching size and distance factors of scars and the channel location between photography sets. It was possible to digitally derive both the permanent and ephemeral fluvial network and the catchment boundary using a digital elevation model but this method was not chosen. Due to distortion from georeferencing of the images, the digitally derived boundaries and the fluvial network would not be comparable between photos. Instead, the catchment outline and the fluvial network were digitised from the aerial photography as vector layers for each photo. The visible ephemeral channels running up from the main stream were also digitised to represent ephemeral density during the storm rainfall events. These were compared to the digitally derived fluvial network derived from the DEM (where all cells with a flow accumulation equal or greater than 150 were considered part of the fluvial network) to estimate their extent upslope. Catchments were also divided into five overlapping nested catchments to observe spatial patterns in sediment delivery as catchment size increases (Figure 4.6 A-E). The boundaries of the nested catchments were defined using the watershed tool in GIS but were digitised on each aerial photo to divide up the catchment.

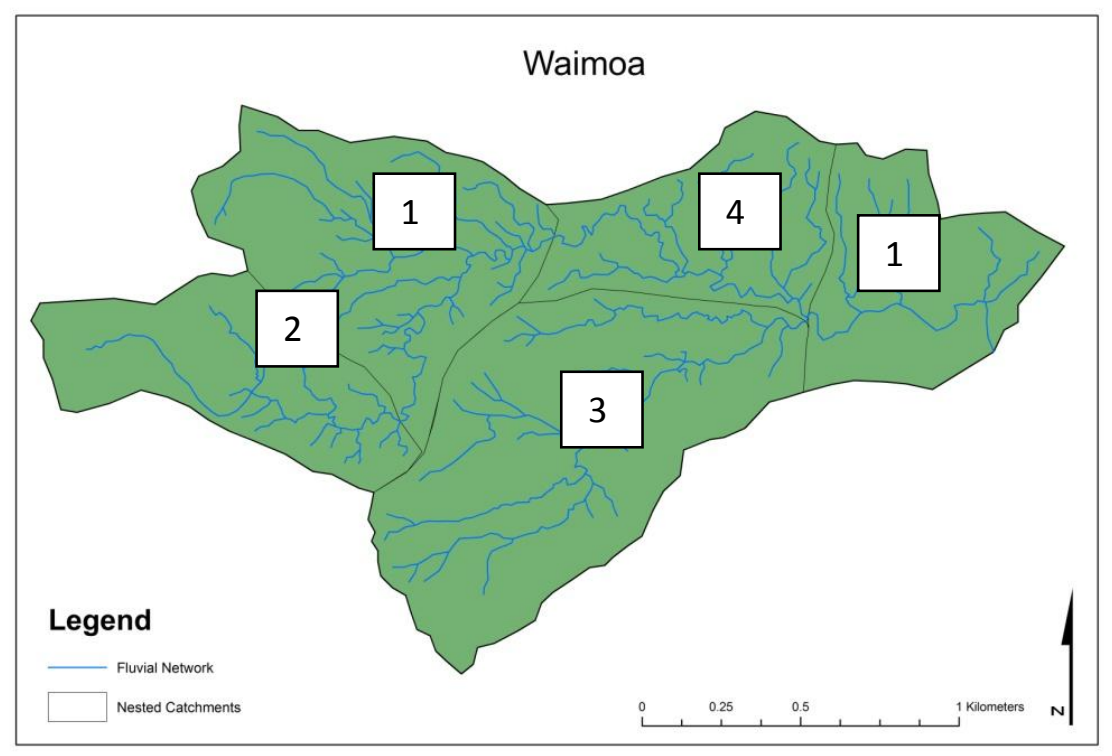

Figure 4.6 A) Nested catchments within the Waimoa Catchment. 

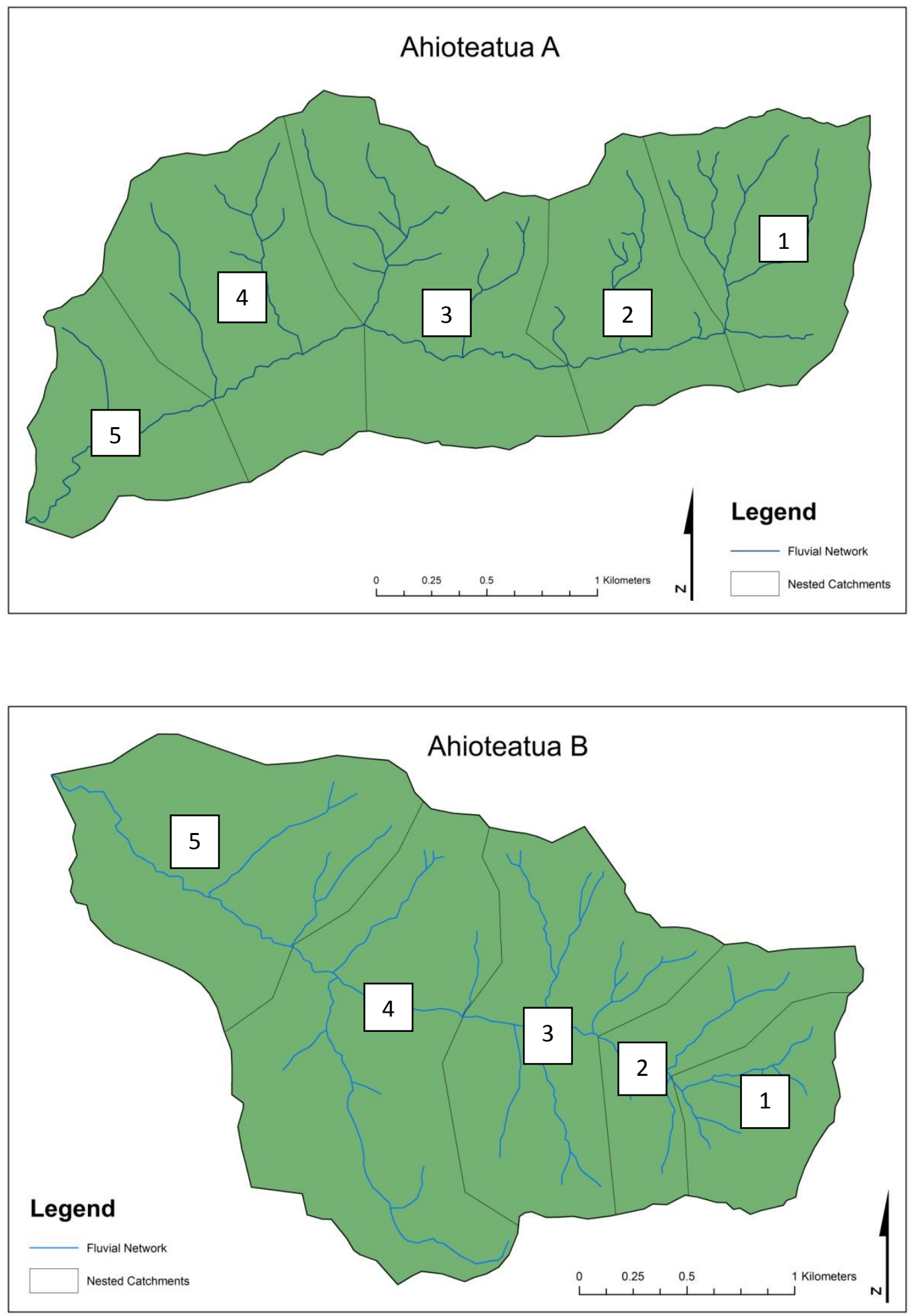

Figure 4.6 Nested catchments within the Ahioteatua Catchments. 

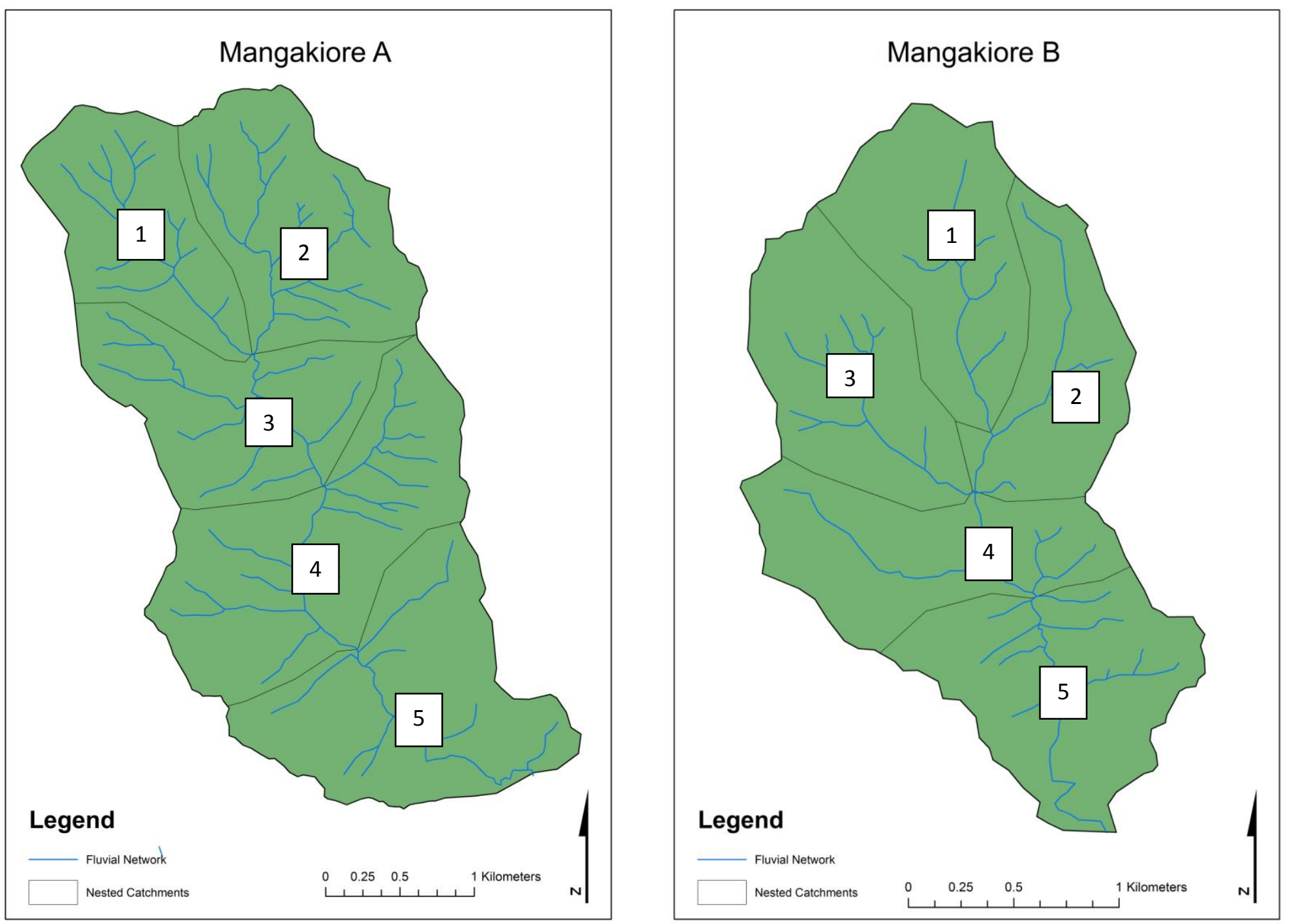

Figure 4.6 Nested catchments within the Mangakiore Catchments. 
With the high resolution scanning, individual landslide scars were visible on the aerial photos within the GIS environment. Landslide scars were identified for each set of aerial photography and digitised as separate polygon layers for each catchment. The landslide scar layer for each photo was created by identifying bare soil values by adding the photo raster layer as one spectral band. <SPATIAL ANALYST> <RECLASSIFY> was used to reclassify the bare soil value range to the single value of 1 and all the other layers as No Data. This layer was then converted from raster to vector using the <SPATIAL ANALYST> tool <CONVERT> Raster to Features with the option of generalizing lines selected. This vector layer was then edited to remove non-landslide derived bare soil polygons and separate polygons for multiple scars. The scars layer was then intersected with the nested catchment layer to separate out the mapped scars into each nested catchments

In the 1988 aerial photography taken directly after Cyclone Bola for both the Mangakiore and Ahioteatua catchments the debris tails from scars were visible. Therefore each scar could be classified as connected or disconnected from the fluvial network. However, this was not possible for the other photography where the storms deemed to be associated with the multiple occurrence landslide event had occurred at least one year prior to the photography and debris tails had become re-grassed. Therefore to keep the techniques equal between photos the debris tails from the 1988 aerial photography were not digitised. Instead, scar length and runout length were estimated for each scar from the regression equations developed at the Hinenui site. The area of each scar was determined in GIS and volume was derived using representative scar depths from Page et al., (1999) for the three land systems.

Additional information on the aspect of the scars was also determined to analyse the spatial pattern of failure location between photos. Aspect was derived from the $25 \mathrm{~m}$ DEM with the <ASPECT $>$ tool under $\langle$ SURFACE $\rangle$. This raster layer was then converted to vector with <3D ANALYSIS $><$ CONVERSION $\rangle$. The landslide scar layer was then intersected with the aspect layer. However, when a failure occurred on more than one aspect polygon it split the scar polygon. Therefore, a Python script was 
written to attribute the aspect which covered the larger percentage of the scar to the ID of that scar before the layer was dissolved.

\subsubsection{Connectivity and Sediment Delivery Ratios}

Ideally, scar layers from each aerial photo are overlaid and this allows for the detailed analysis of scar location between the aerial photos. From this, individual scars could be pinpointed where they show reactivation of the scar crown and migration away from the channels. But because of the off-set for each photo indicated by Figures 4.5 A-E above this technique would not be reliable. Rather, a new method was developed which allowed for comparison of upslope retreat of scars between photos without overlaying the scar layers from each photo.

Buffer layers at $10 \mathrm{~m}$ intervals from the channel network divided up the catchment and these layers were intersected with the failures. Where there were multiple instances of individual failures located in two or more buffer layers, they were were edited so that these scars were classed into the buffer layer which was closest to the channel network. Thus, it was possible to determine whether there was any change in the cumulative percentage of failures located within each buffer zone over time. For example, it was possible to tell if $80 \%$ of the failures were located within $50 \mathrm{~m}$ of the channel network in the 1943 aerial photo, but only 30\% occurred within this distance in the 2004 photo while $60 \%$ occurred within $150 \mathrm{~m}$ of the channel network.

While it would have been more accurate to measure the distance between the failure and the nearest downslope channel in order to determine whether it is connected. This was not possible in the time frame of this thesis due to the extremely large number of scars observed. Rather, the total length of each earthflow was determined from the combination of the scar length and debris tail runout distance and this was used to establish whether each earthflow was connected or disconnected to the fluvial network.

Where the total length of the scar and debris tail was greater than the distance of the buffer layer from the channel, the failure was deemed connected. Where the total length 
of the scar and debris tail was less than the distance of the buffer layer from the channel the failure was deemed disconnected. This is likely to underestimate the total number of connected failures, since some failures will be connected when they occur at the lower boundary of the buffer layer, but since their total length is less than the upper limit of the buffer layer they are recorded as disconnected (Figure 4.7). However, since $10 \mathrm{~m}$ buffers were used, which are lower than the average scar length measured by Page et al., (1999) for the three land systems, this error margin is low and is unlikely to distort the derived connected values greatly.

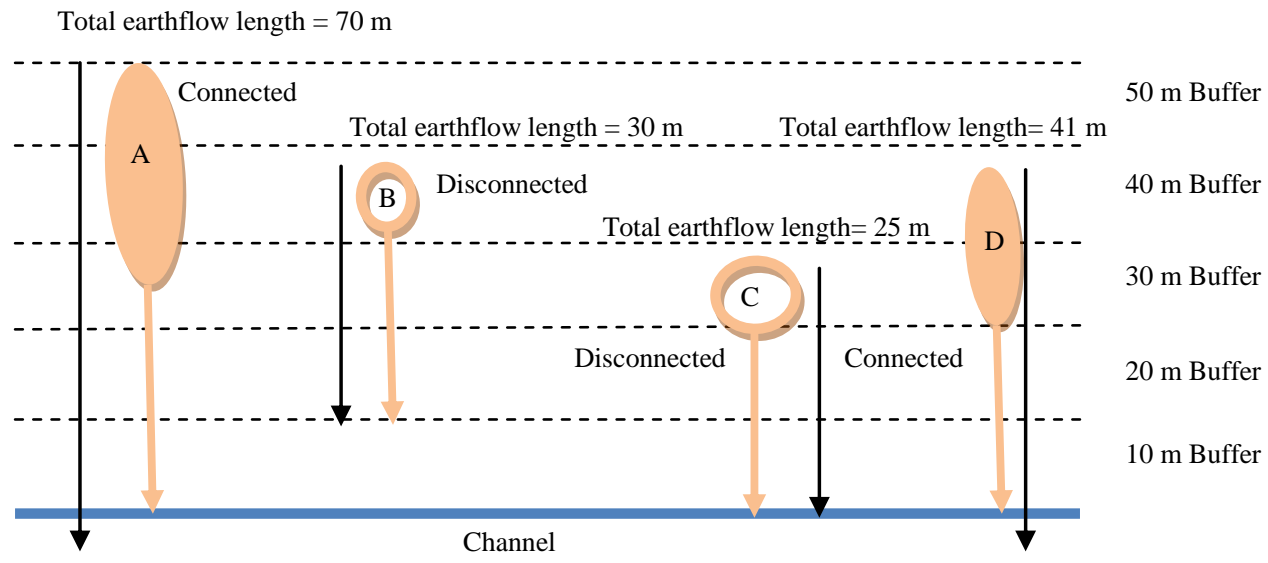

Figure 4.7 Sources of error when deriving connectivity from buffered layers. Failures A \& D (closed) are connected as the total earthflow length (combined scar and debris tail runout length) is greater than the buffer distance from the channel network. Scars B \& C (open) are disconnected. The total length (combined scar and debris tail runout length) of both these scars is less than the buffer distance from the channel network.

Sediment delivery ratios for each of the connected earthflows were derived from the regression equation developed from Hinenui. The sediment delivery ratio $(\%)$ for each scar was multiplied by the volume of that scar $\left(\mathrm{m}^{3}\right)$ to determine the total volume $\left(\mathrm{m}^{3}\right)$ of delivered sediment for that scar (Equation 4.1). The total volume $\left(\mathrm{m}^{3}\right)$ of delivered sediment was then summed. The catchment sediment delivery ratio was calculated from the total volume of delivered sediment compared to the total volume of generated sediment obtained from the scar volumes (Equation 4.2). 
Vcs $*$ Individual SDR $=\mathrm{Vd}$

${ }^{\mathrm{T}} \mathrm{Vd} /{ }^{\mathrm{T}} \mathrm{V}=$ Catchment SDR
Equation 4.1

Equation 4.2

SDR $=$ Sediment Delivery Ratio $(\%)$

Vcs $=$ Volume Connected Scar $\left(\mathrm{m}^{3}\right)$

${ }^{(T)} \mathrm{Vd}=$ (Total) Volume of delivered sediment $\left(\mathrm{m}^{3}\right)$

${ }^{\mathrm{T}} \mathrm{V} \quad=$ Total volume of sediment generated by earthflows $\left(\mathrm{m}^{3}\right)$

The spatial patterns in sediment delivery are determined from comparing the sediment delivery values of each of the five nested catchments to the increasing catchment area for each individual nested catchment. Temporal patterns in sediment delivery are determined by comparing the sediment delivery ratios of the largest nested catchment (Nested Catchment Five representing the entire catchment) for each photo for each individual catchment.

\subsection{Summary}

This methodology has an empirical structure that involves a three stage process of identifying failure location, determining connectivity and characterising sediment delivery ratios through observation of failure characteristics at different temporal and spatial stages. Furthermore, it requires the recognition of the changes in the potential for delivery of the failed mass. This is based first on the development of a multiple regression model to predict sediment delivery ratios and account for local variations from site to site. Secondly, the changes in both connectivity and sediment delivery can be compared at the varying spatial and temporal scales for each field site.

The results and analysis for sediment delivery ratios developed for this research are given over the next two chapters. Chapter Five displays the results of determining sediment delivery ratios and gives a description of the observed changes in sediment delivery ratios throughout the three field sites used to represent the Waipaoa catchment. Chapter Six discusses the trends observed in the previous chapter, considering these changes in the context of stages in catchment evolution. 


\section{Chapter Five: Spatial and Temporal Patterns of Sediment Delivery Ratios}

\subsection{Introduction}

In the previous chapter, the methods for observing slope channel coupling and deriving associated catchment sediment delivery ratios were described. This chapter presents the results from this analysis to display the spatial and temporal pattern in sediment delivery. The first section of this chapter displays the results of the regression analysis of the Hinenui earthflows. The following sections of this chapter display the determined off-slope catchment sediment delivery ratios and explore the spatial and temporal patterns in off-slope sediment delivery. Further discussion of these results is given in the following chapter.

\subsection{Multiple Regression Analysis of the Hinenui Earthflows}

This section presents the results from the regression analysis undertaken at the Hinenui field site to model sediment delivery ratios for individual failures. The regression equations given in this chapter represent the most reliable models developed from the Hinenui dataset. The full set of regression equations developed are given in Appendix B. Further discussion on these results is given in Chapter Six.

\subsubsection{Analysis of Multiple Variables}

Stepwise multiple regression analysis was undertaken in STATGRAPHICS Centurion $\mathrm{XV}$ version 15.2.14 using the following variables to develop regression equations for sediment delivery ratios, runout length and scar volume: 
Dependent Variables:

Ds Sediment Delivery Ratio (\%)

Lr Runout length (m)

Vs Scar volume $\left(\mathrm{m}^{3}\right)$ $\underline{\text { Independent Variables: }}$

Ls $\quad$ Scar length $(\mathrm{m})$

Lr Runout length (m)

Vs Scar volume $\left(\mathrm{m}^{3}\right)$

$\mathrm{Sr} \quad$ Slope angle of the runout path $\left(^{\circ}\right)$

$\mathrm{Er} \quad$ Elevation change of the runout path (m)

$\mathrm{Cr} \quad$ Profile curvature of the runout path

Since liquid limit was collected to determine the soil properties for the catchment as a whole, it was not suitable for regression analysis for individual failures as it was a constant variable. Most of the other values are positively skewed and have large variation values. Therefore, both $\log$ and square root transformations were carried out to normalise selected variables (Table 5.1). Length (Lr), slope angle (Sr) and profile curvature $(\mathrm{Cr})$ of the runout paths were excluded from transformations because this did not reduce their skewness. However, profile curvature of the runout path $(\mathrm{Cr})$ still shows standardized kurtosis values outside the expected range which could invalidate many of the statistical procedures normally applied to this data.

Table 5.1 Summary of the frequency distribution statistics for the variables used on this study for 71 earthflows and the debris tail runout paths.

\begin{tabular}{|l|c|c|c|c|c|c|c|}
\hline & Cr & $L O G \_L s$ & $L O G \_V s$ & Lr & $S Q R T \_D s$ & $S Q R T \_E r$ & Sr \\
\hline Count & 71 & 71 & 71 & 71 & 71 & 71 & 71 \\
\hline Average & 0.26 & 1.61 & 1.63 & 58.04 & 3.71 & 4.42 & 27.38 \\
\hline $\begin{array}{l}\text { Standard } \\
\text { deviation }\end{array}$ & 0.53 & 0.24 & 0.46 & 30.43 & 2.80 & 1.44 & 8.86 \\
\hline $\begin{array}{l}\text { Coeff. } \\
\text { variation }\end{array}$ & & & & & & & \\
\hline Minimum & -1.6 & 1.08 & 0.66 & 2.0 & 0.0 & 0.71 & 2.12 \\
\hline Maximum & 1.4 & 2.07 & 2.47 & 117.0 & 9.75 & 7.21 & 48.80 \\
\hline Range & 3.0 & 1.00 & 1.81 & 115.0 & 9.75 & 6.50 & 46.67 \\
\hline Stnd. skewness & -2.06 & -0.43 & -0.58 & 0.64 & 1.52 & -0.74 & -0.70 \\
\hline Stnd. kurtosis & 2.35 & -1.40 & -1.46 & -1.44 & -1.13 & -0.28 & 0.82 \\
\hline
\end{tabular}


Pearson product moment correlations between each pair of variables were determined (Table 5.2). P-values below 0.05 indicate statistically significant correlations at the 95.0\% confidence level. The following pairs of variables have P-values below 0.05 :

- $\quad L O G \_$Vs and SQRT_Ds

- $\quad L O G_{-} \mathrm{Ls}$ and $L O G_{-} \mathrm{Vs}$

- $\quad L r$ and $S Q R T \_E r$

- SQRT_Er and Sr

However, only one variable is paired to delivery and the correlation value is low.

Table 5.2 Pearson product moment correlations between the variables used for the regression analysis at Hinenui for the 71 earthflows and the debris tail runout paths.

\begin{tabular}{|c|c|c|c|c|c|c|c|}
\hline & & $\mathrm{Cr}$ & $L O G \_L s$ & $L O G_{-} \mathrm{Vs}$ & Lr & SQRT_Ds & $S Q R T$ Sr \\
\hline Correlation & \multirow[t]{2}{*}{$\mathrm{Cr}$} & & & & & & \\
\hline \multicolumn{7}{|l|}{ P-Value } & \\
\hline Correlation & \multirow[t]{2}{*}{$L O G \_L s$} & -0.0165 & & & & & \\
\hline P-Value & & 0.8915 & & & & & \\
\hline Correlation & \multirow[t]{2}{*}{$L O G_{-} V_{s}$} & -0.0453 & 0.9835 & & & & \\
\hline P-Value & & 0.7078 & 0.0000 & & & & \\
\hline Correlation & \multirow[t]{2}{*}{$\mathbf{L r}$} & 0.1144 & 0.0379 & 0.0264 & & & \\
\hline P-Value & & 0.3420 & 0.7535 & 0.8272 & & & \\
\hline Correlation & \multirow[t]{2}{*}{$S Q R T_{\text {DDs }}$} & 0.0576 & 0.2316 & 0.2369 & 0.1396 & & \\
\hline P-Value & & 0.6331 & 0.0519 & 0.0467 & 0.2457 & & \\
\hline Correlation & \multirow[t]{2}{*}{$S Q R T_{-} \mathbf{E r}$} & 0.1396 & 0.0456 & 0.0528 & 0.9037 & 0.1032 & \\
\hline P-Value & & 0.2457 & 0.7059 & 0.6619 & 0.0000 & 0.3917 & \\
\hline Correlation & \multirow[t]{2}{*}{$\mathbf{S r}$} & -0.0158 & 0.0714 & 0.0911 & 0.0574 & 0.0781 & 0.2804 \\
\hline P-Value & & 0.8958 & 0.5540 & 0.4497 & 0.6343 & 0.5174 & 0.0179 \\
\hline
\end{tabular}




\subsubsection{Multiple Regression Analysis of Sediment Delivery}

Multiple regression modelling was used in an attempt to produce a reliable predictive model for sediment delivery ratios for individual failures. While volume of the scar (Vs) was the only variable which displayed a statistically significant relationship with the sediment delivery off-slope (Ds) and from this the following linear regression equation was developed:

$P$-value $=0.04$

SQRT_Ds $=1.34765+1.44959 * L O G \_V s$

$R^{2}=0.06$

Std. $E .=2.24$

Equation 5.1

However, this model only accounts for $5.6 \%$ of the variability in sediment delivery ratios. The addition of the other variables improved the model and the multiple regression equation was developed which accounted for $9.6 \%$ of the variability in sediment delivery ratios but the $\mathrm{P}$-value is greater than 0.05 . Therefore, it indicates that there is no statistically significant relationship between the variables at $95 \%$ or higher confidence levels. Consequently, neither regression equations were considered to be useful.

Equation 5.1 could be considered invalid since the data set from which it was developed included failures which did not connected and therefore by definition had a sediment delivery ratio of $0 \%$. Therefore multiple regression analysis was repeated excluding the scars which did not deliver sediment off-slope (excluding $28 \%$ of the scars at Hinenui). For this data set, none of the independent variables displayed a statistically significant relationship with sediment delivery and again these regression equations were not considered to be useful.

\subsubsection{Multiple Regression Analysis of Runout Modelling}

Additional multiple regression analysis was undertaken to develop a model to predict debris tail runout length. The aim for this equation, calibrated from the Hinenui field 
site, is for it to be used in the other field sites of Wharekopae, Waihora and Te Arai to predict runout distances from scars observed on the aerial photography. From the Hinenui site the dependent variable runout length $(\mathrm{Lr})$ displays a statistically significant correlation with the change in elevation of the runout path (Er) (Table 5.2). The regression model is improved with the addition of all the other variables except for curvature of the runout path $(\mathrm{Cr})$. From this, the following regression equation was developed:

$R^{2}=0.86$

$$
\begin{aligned}
& \mathrm{Lr}=\mathbf{- 5 4 . 1 6 2 4}+55.0778 * L O G \_L s-29.1542 * L O G \_V s \\
& +20.4421 * S Q R T_{-} \mathrm{Er}-0.701875 * \mathrm{Sr}
\end{aligned}
$$

$P$-value $=0.0$

Stnd. E. $=11.5$

\section{Equation 5.2}

This model accounts for $86 \%$ of the variability in runout length and since the P-value is less than 0.05 there is a statistically significant relationship between the variables at $95 \%$ or higher confidence level. There is also greater confidence when the change in elevation of the runout path is low, because as the elevation change of the runout path increases, so does the deviation from the fitted model (Figure 5.1). While this model is highly predictive it is the change in elevation (Er) variable which is vital. When this variable is removed from the regression analysis the model only predicts $2 \%$ of the variability in runout. 
Component+Residual Plot for Lr

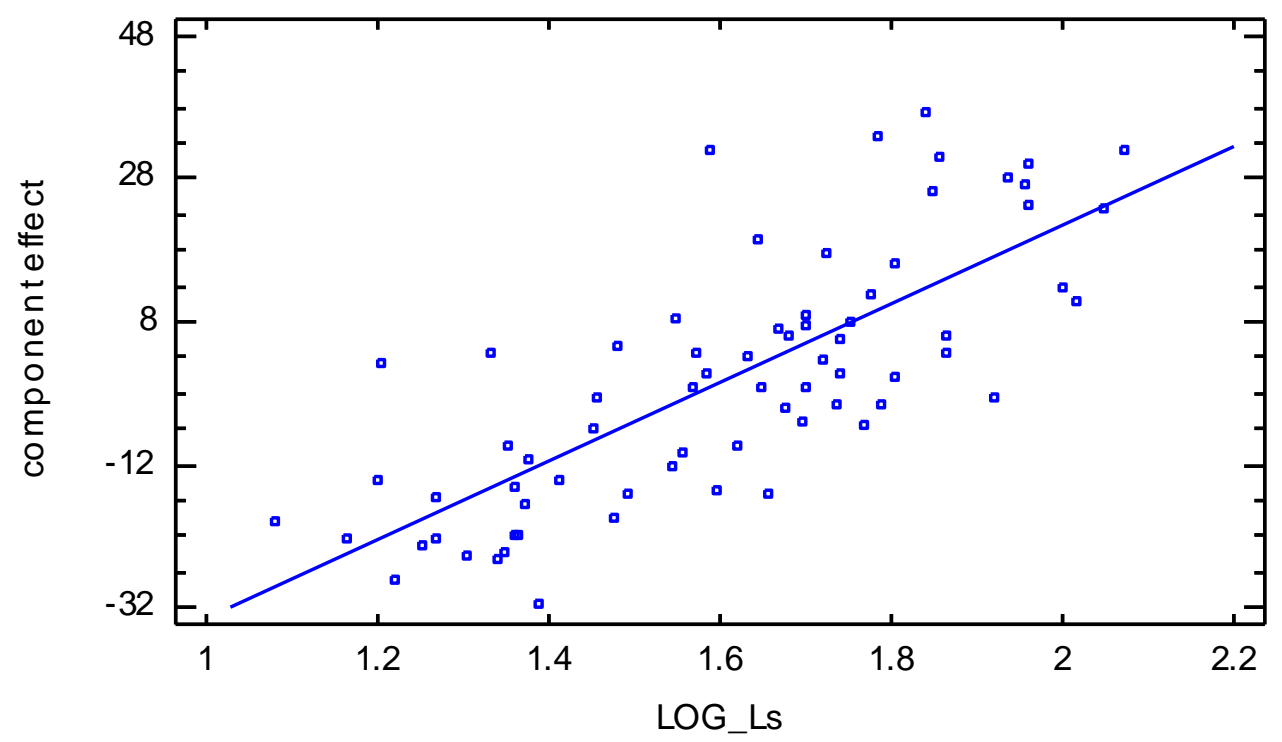

Figure 5.1 Plot of the fitted model developed to predict earthflow runout length (Lr) with the change of elevation between the start and end of the runout path (Er) and slope of the runout path $(\mathrm{Sr})$.

\subsubsection{Multiple Regression Analysis of Scar Length Modelling}

Multiple regression analysis was once more undertaken to develop a model to predict scar length. For this regression, the dependent variable of scar length (Ls) displays a statistically significant correlation with the volume of the scar (Vs) (Table 5.2). Hence, the following regression equation was developed:

$R 2=0.97$

$$
L O G \_L s=0.757159+0.522185 * L O G_{-} V s
$$

$P$-value $=0.0$

Stnd $E .=0.04$

Equation 5.3

This model accounts for $97 \%$ of the variability in scar length and since the P-value is less than 0.05 there is a statistically significant relationship between the variables at $95 \%$ or higher confidence level. Therefore, this regression equation is valid and can be 
applied to the other field sites used in this thesis with confidence (Figure 5.2). Nevertheless, this regression equation is not ideal due to its circular nature as scar volume is a derivative of scar length.

Plot of Fitted Model

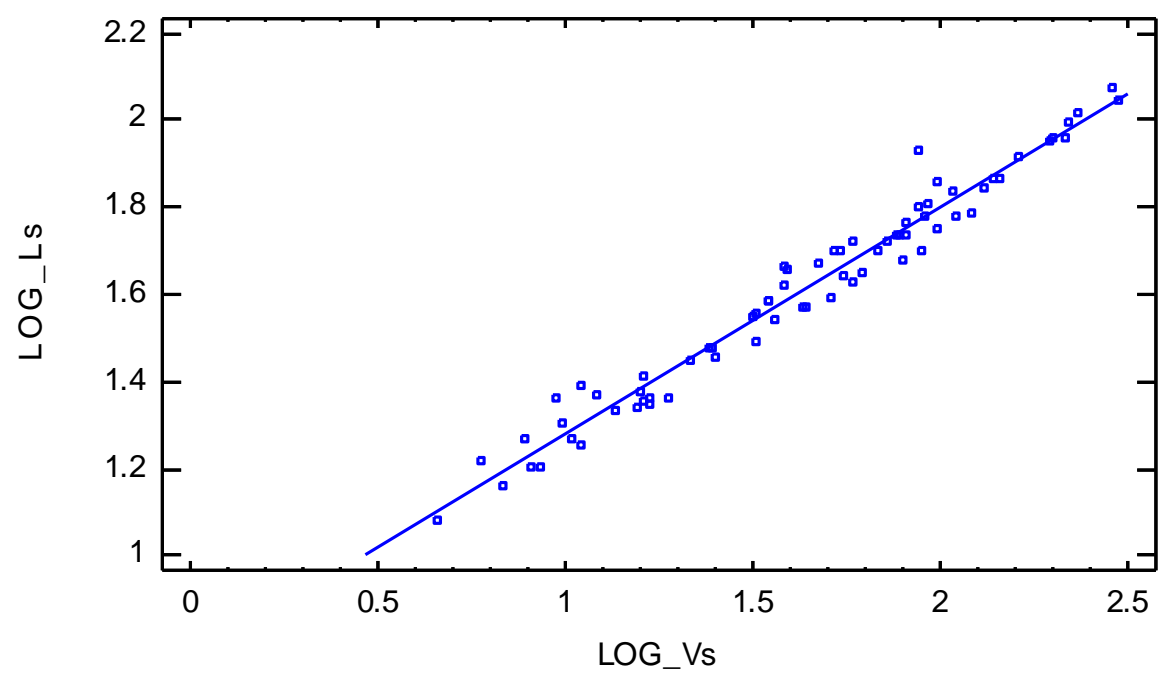

Figure 5.2 Plot of the fitted model developed to predict scar length (Ls) using the independent variable scar volume (Vs).

\subsubsection{Regression Summary}

The above results for predicting sediment delivery ratios are surprising. Since catchment morphology and scar size are considered important in terms of slope channel coupling, they could also be assumed to influence sediment delivery. However, the results of this analysis using the above variables, has developed a regression model which predicts very little of the variability in off-slope sediment delivery. Further discussion on the low confidence in this model is given in the Chapter Seven. However, the regression analyisis to predict debris tail runout distance and scar length resulted in highly predictive models but they are circular in nature. The extent to which the above models are applied in the other field site cathcments is explained in the following section. 


\subsection{Sediment Delivery}

\subsubsection{Introduction}

The initial strategy for the analysis of spatial and temporal trends in sediment delivery was to use the regression model developed from the empirical dataset of off-slope sediment delivery at the Hinenui field site. This regression equation was to be used to calculate the sediment delivery ratio for individual earthflows and from these sediment delivery ratios derived for each nested catchment. However, due to the low correlation between both landslide characteristics and morphometric properties in relation to offslope sediment delivery, this model cannot be used with any confidence. Also, the regression equation to predict runout distance, while accurate, is hard to apply due to the elevation change of the runout path being itself dependent on the distance of the runout. Therefore, neither the sediment delivery nor the runout distance regression equations have been used.

Instead, the sediment delivery ratio for connected failures was assumed to be $27 \%$ which was the average sediment delivery ratio established for the connected earthflows at Hinenui catchment in 2002. Catchment sediment delivery ratios were also derived using an assumed individual ratio of 50\%, but the results of this are presented in Appendix C. This $27 \%$ ratio estimated from Hinenui could be considered an underestimation where the slopes, being less steep than other sites in the Waipaoa catchment and abutting alluvial terraces, could be assumed to have higher percentages of on-slope and within channel storage.

For determining runout a number of options were considered. A predictive model from previous research in the Manawatu region by Crozier, (1996), would have been more accurate than a standard ratio for runout length. But no data was collected about liquid limit of the soil for the five catchments and so therefore this cannot be applied. Another runout ratio derived by Corominas et al., (1991), developed for the Pyrenees, but which excluded soil properties, was not considered accurate for use on the Waipaoa catchment 
due to the extremely low runout values it determined. Identification of which failures were connected to the channel network can only be determined for two out of three sites from the aerial photography taken after Cyclone Bola. Therefore, while runout ratios could have been derived from this for the Ahioteatua and Mangakiore sites, the Waimoa catchment would have been excluded.

So to keep the techniques consistent between all the catchments connectivity was determined using a runout length ratio of 3:1 to scar length. The average runout length to scar length ratio for the Hinenui site was developed as 1.7:1, but the maximum runout length was only $117 \mathrm{~m}$ before the debris tail intersected the ephemeral channel. Also the regression equation for runout highlights the important of the change in elevation between the scar base and the debris tail terminus. This difference is likely to be greater at the five catchments (especially in the Ahioteatua and Mangakiore catchments) within the Waipaoa catchment since they generally have longer, steeper slopes compared to Hinenui. For these reasons, the Hinenui ratio is expected to underestimate runout length at the other catchments within the Waipaoa catchment were the slopes are steeper and longer. Empirical runout ratios developed for the Tutira in Hawkes Bay for Cyclone Bola in 1988 were 2.64:1 (Schneider, 2002), Wanganui - Manawatu area in the lower North Island are 3.22:1 for a 1992 storm event (Crozier, 1996) and range from 2.62:1 to 3.48:1 for a 2004 storm event (Hancox and Wright, 2005). Thus, Croizer (2005) suggested runout may be a function of inherent slope conditions rather than rainfall duration or magnitude. Because of this the 3:1 ratio used, while considered suitable, is only indicative of the real conditions and this is a source of error in determining connectivity of each catchment.

\subsubsection{Total Volume of Sediment Generated}

For each nested catchment at the five field site catchments the total volume of sediment generated from landsliding was determined (Table 5.3). The total volume of sediment generated varied greatly between years. In the Waimoa catchment the estimation of the total volume of sediment generated was high in the 1952, 1974 and 2004 aerial photos. In comparison, the total volume of sediment generated by scars evident in the 1965 
photo was low compared to the other years. In the Ahioteatua catchments the total volume of sediment generated was exceptionally low in 2004 compared to the other years. In catchment A, large volumes of generated sediment were estimated in the aerial photos from 1952 to 1982 . In the 1988 aerial photo the outlet of catchment A was missing and therefore only four nested catchments were represented. In spite of this the total volume of nested catchment four is the highest in 1988 from the scars are attributed to Cyclone Bola. Again in catchment B the 1988 aerial photo had the highest estimates of sediment generated due to Cyclone Bola. Once more in the Mangakiore Catchments Cyclone Bola was recorded as an extreme event with very high estimates of the total volume of sediment generated. Comparably high volumes were also estimated for the 1965 aerial photo. In general the total volumes were higher in Mangakiore Catchment A due to its larger size than Catchment B. 
Table 5.3 Total Volume of sediment generated in the Waimoa, Ahioteatua and Mangakiore Catchments from earthflows for each nested catchment.

\begin{tabular}{|c|c|c|c|c|c|c|c|c|c|}
\hline \multicolumn{10}{|c|}{ Waimoa Catchment } \\
\hline $\begin{array}{c}\text { Nested } \\
\text { Catchment }\end{array}$ & & & $\begin{array}{r}1952 \\
\times 10^{3} \mathrm{~m}^{3} \\
\end{array}$ & $\begin{array}{r}\mathbf{1 9 6 5} \\
\times 10^{3} \mathrm{~m}^{3} \\
\end{array}$ & $\begin{array}{r}\mathbf{1 9 7 4} \\
\times 10^{3} \mathrm{~m}^{3} \\
\end{array}$ & $\begin{array}{r}\mathbf{1 9 8 0} \\
\times 10^{3} \mathrm{~m}^{3} \\
\end{array}$ & $\begin{array}{r}1984 \\
\times 10^{3} \mathrm{~m}^{3} \\
\end{array}$ & & $\begin{array}{r}2004 \\
\times 10^{3} \mathrm{~m}^{3} \\
\end{array}$ \\
\hline 1 & & & 2.0 & 3.4 & 2.2 & 2.5 & 0.6 & & 1.9 \\
\hline 2 & & & 2.7 & 5.3 & 6.5 & 2.7 & 1.2 & & 3.4 \\
\hline 3 & & & 12.0 & 7.6 & 6.8 & 4.3 & 7.4 & & 10.9 \\
\hline 4 & & & 14.7 & 9.3 & 14.5 & 6.9 & 8.6 & & 14.3 \\
\hline 5 & & & 25.1 & 9.5 & 21.9 & 14.6 & 16.6 & & 22.9 \\
\hline \multicolumn{10}{|c|}{ Ahioteatua Catchment A } \\
\hline $\begin{array}{c}\text { Nested } \\
\text { Catchment }\end{array}$ & $\begin{array}{r}1943 \\
\times 10^{3} \mathrm{~m}^{3}\end{array}$ & & $\begin{array}{c}\mathbf{1 9 5 2} \\
\mathrm{x} 10^{3} \mathrm{~m}^{3}\end{array}$ & $\begin{array}{r}1969 \\
\times 10^{3} \mathrm{~m}^{3}\end{array}$ & & $\begin{array}{c}\mathbf{1 9 8 2} \\
\mathrm{x} 10^{3} \mathrm{~m}^{3}\end{array}$ & & $\begin{array}{c}\mathbf{1 9 8 8} \\
\mathrm{x} 10^{3} \mathrm{~m}^{3}\end{array}$ & $\begin{array}{r}2004 \\
\times 10^{3} \mathrm{~m}^{3}\end{array}$ \\
\hline 1 & 20.3 & & 69.5 & 16.9 & & 60.4 & & 40.3 & 2.6 \\
\hline 2 & 61.6 & & 128.2 & 77.9 & & 119.7 & & 67.1 & 7.6 \\
\hline 3 & 104.0 & & 188.5 & 131.7 & & 151.6 & & 141.4 & 19.4 \\
\hline 4 & 145.5 & & 245.9 & 206.6 & & 223.7 & & 265.9 & 23.4 \\
\hline 5 & 258.9 & & 352.6 & 346.2 & & 364.7 & & & 33.5 \\
\hline \multicolumn{10}{|c|}{ Ahioteatua Catchment B } \\
\hline $\begin{array}{c}\text { Nested } \\
\text { Catchment }\end{array}$ & $\begin{array}{r}1943 \\
\times 10^{3} \mathrm{~m}^{3} \\
\end{array}$ & & $\begin{array}{c}\mathbf{1 9 5 2} \\
\times 10^{3} \mathrm{~m}^{3}\end{array}$ & $\begin{array}{r}\mathbf{1 9 6 9} \\
\times 10^{3} \mathrm{~m}^{3}\end{array}$ & & $\begin{array}{r}\mathbf{1 9 8 2} \\
\times 10^{3} \mathrm{~m}^{3}\end{array}$ & & $\begin{array}{c}\mathbf{1 9 8 8} \\
\times 10^{3} \mathrm{~m}^{3}\end{array}$ & $\begin{array}{r}2004 \\
\times 10^{3} \mathrm{~m}^{3} \\
\end{array}$ \\
\hline 1 & 28.9 & & 4.5 & 14.8 & & 14.8 & & 14.8 & 6.1 \\
\hline 2 & 100.8 & & 13.3 & 26.4 & & 26.3 & & 38.2 & 17.5 \\
\hline 3 & 160.8 & & 32.1 & 47.6 & & 47.6 & & 76.5 & 25.9 \\
\hline 4 & 236.3 & & 75.8 & 70.3 & & 70.3 & & 119.7 & 38.3 \\
\hline 5 & 295.5 & & 149.0 & 98.3 & & 206.4 & & 308.8 & 60.8 \\
\hline \multicolumn{10}{|c|}{ Mangakiore Catchment A } \\
\hline $\begin{array}{c}\text { Nested } \\
\text { Catchment }\end{array}$ & & $\begin{array}{r}1949 \\
\times 10^{3} \mathrm{~m}^{3}\end{array}$ & & $\begin{array}{r}1965 \\
\times 10^{3} \mathrm{~m}^{3}\end{array}$ & $\begin{array}{r}\mathbf{1 9 7 4} \\
\times 10^{3} \mathrm{~m}^{3}\end{array}$ & & & $\begin{array}{l}1988 \\
\times 10^{3} \mathrm{~m}^{3}\end{array}$ & $\begin{array}{l}2004 \\
\times 10^{3} \mathrm{~m}^{3}\end{array}$ \\
\hline $\mathbf{1}$ & & 9.1 & & 116.3 & 72.6 & & & 140.5 & 4.5 \\
\hline 2 & & 17.8 & & 163.2 & 135.2 & & & 198.2 & 5.2 \\
\hline 3 & & 39.4 & & 220.2 & 167.8 & & & 356.2 & 29.9 \\
\hline 4 & & 112.4 & & 366.2 & 267.8 & & & 575.4 & 71.3 \\
\hline 5 & & 216.7 & & 567.2 & 400.1 & & & 1004.2 & 137.0 \\
\hline \multicolumn{10}{|c|}{ Mangakiore Catchment B } \\
\hline $\begin{array}{c}\text { Nested } \\
\text { Catchment }\end{array}$ & & $\begin{array}{r}1949 \\
\times 10^{3} \mathrm{~m}^{3}\end{array}$ & & $\begin{array}{r}\mathbf{1 9 6 5} \\
\times 10^{3} \mathrm{~m}^{3}\end{array}$ & $\begin{array}{c}\mathbf{1 9 7 4} \\
\times 10^{3} \mathrm{~m}^{3}\end{array}$ & & & $\begin{array}{c}\mathbf{1 9 8 8} \\
\times 10^{3} \mathrm{~m}^{3}\end{array}$ & $\begin{array}{c}2004 x \\
10^{3} \mathrm{~m}^{3}\end{array}$ \\
\hline 1 & & 13.4 & & 38.8 & 16.9 & & & 43.6 & 0.4 \\
\hline 2 & & 39.9 & & 64.0 & 28.1 & & & 76.1 & 2.4 \\
\hline 3 & & 46.2 & & 127.3 & 33.5 & & & 115.7 & 4.4 \\
\hline 4 & & 97.4 & & 197.9 & 36.8 & & & 174.2 & 18.9 \\
\hline 5 & & 179.6 & & 385.1 & 57.1 & & & 355.3 & 56.5 \\
\hline
\end{tabular}




\subsubsection{Total Volume of Sediment Delivered}

The total volume of sediment delivered off-slope to the fluvial network (both ephemeral channels and permanent streams) is shows minimal variation throughout the aerial photos in the Waimoa catchment (Table 5.4). In the Ahioteatua catchments the total volume of sediment delivered off-slope varied between years. An exceptionally low volume of sediment was delivered to the fluvial network in the 2004 aerial photo for both catchments and also in the 1969 photo for catchment B. Overall in Ahioteatua Catchment A the total volume of sediment delivered is generally higher (Table 5.4) but Cyclone Bola in 1988 was responsible for the largest volume of off-slope sediment being delivered in Catchment B (Table 5.4). Again, in the Mangakiore Catchments Cyclone Bola produced the largest volumes of delivered sediment and the lowest volumes were estimated in the 2004 aerial photo. Higher rates of delivered sediment were estimated for Catchment A and the extremely high volume of delivered sediment in the 1988 photo is due to the deep seated slide observed in this photo (Table 5.4). In catchment B a low volume of delivered sediment was also estimated for the 1974 aerial photo (Table 5.4) and this was not matched in Catchment A. 
Table 5.4 Total volume of sediment delivered to the fluvial network in the Waimoa, Ahioteatua and Mangakiore Catchments from earthflows for each nested catchment.

\begin{tabular}{|c|c|c|c|c|c|c|c|c|c|}
\hline \multicolumn{10}{|c|}{ Waimoa Catchment } \\
\hline $\begin{array}{c}\text { Nested } \\
\text { Catchment }\end{array}$ & & & $\begin{array}{r}1952 \\
\times 10^{3} \mathrm{~m}^{3}\end{array}$ & $\begin{array}{r}\mathbf{1 9 6 5} \\
\times 10^{3} \mathrm{~m}^{3}\end{array}$ & $\begin{array}{r}\mathbf{1 9 7 4} \\
\times 10^{3} \mathrm{~m}^{3}\end{array}$ & $\begin{array}{l}1980 \\
\times 10^{3} \mathrm{~m}^{3}\end{array}$ & $\begin{array}{r}1984 \\
\times 10^{3} \mathrm{~m}^{3}\end{array}$ & & $\begin{array}{r}2004 \\
\times 10^{3} \mathrm{~m}^{3}\end{array}$ \\
\hline 1 & & & 0.3 & 0.8 & 0.4 & 0.6 & 0.1 & & 0.4 \\
\hline 2 & & & 0.5 & 2.1 & 1.8 & 0.7 & 0.3 & & 0.8 \\
\hline 3 & & & 2.9 & 2.5 & 3.4 & 1.6 & 1.9 & & 3.3 \\
\hline 4 & & & 3.1 & 2.9 & 3.5 & 1.7 & 2.1 & & 3.3 \\
\hline 5 & & & 3.9 & 3.0 & 3.8 & 2.7 & 2.8 & & 3.9 \\
\hline \multicolumn{10}{|c|}{ Ahioteatua Catchment A } \\
\hline $\begin{array}{c}\text { Nested } \\
\text { Catchment }\end{array}$ & $\begin{array}{r}\mathbf{1 9 4 3} \\
\times 10^{3} \mathrm{~m}^{3} \\
\end{array}$ & & $\begin{array}{r}1952 \\
\times 10^{3} \mathrm{~m}^{3} \\
\end{array}$ & $\begin{array}{r}\mathbf{1 9 6 9} \\
\times 10^{3} \mathrm{~m}^{3} \\
\end{array}$ & & $\begin{array}{r}\mathbf{1 9 8 2} \\
\times 10^{3} \mathrm{~m}^{3} \\
\end{array}$ & & $\begin{array}{r}\mathbf{1 9 8 8} \\
\times 10^{3} \mathrm{~m}^{3} \\
\end{array}$ & $\begin{array}{r}2004 \\
\times 10^{3} \mathrm{~m}^{3}\end{array}$ \\
\hline 1 & 4.3 & & 17.0 & 3.9 & & 15.3 & & 10.6 & 0.4 \\
\hline 2 & 14.3 & & 32.0 & 19.7 & & 29.6 & & 17.3 & 1.4 \\
\hline 3 & 23.5 & & 46.6 & 32.9 & & 36.8 & & 36.2 & 3.3 \\
\hline 4 & 31.9 & & 60.6 & 51.2 & & 54.8 & & 48.0 & 3.7 \\
\hline 5 & 43.6 & & 64.4 & 64.5 & & 67.0 & & & 3.9 \\
\hline \multicolumn{10}{|c|}{ Ahioteatua Catchment B } \\
\hline $\begin{array}{c}\text { Nested } \\
\text { Catchment }\end{array}$ & $\begin{array}{r}1943 \\
\times 10^{3} \mathrm{~m}^{3} \\
\end{array}$ & & $\begin{array}{r}1952 \\
\times 10^{3} \mathrm{~m}^{3} \\
\end{array}$ & $\begin{array}{r}1969 \\
\times 10^{3} \mathrm{~m}^{3} \\
\end{array}$ & & $\begin{array}{r}1982 \\
\times 10^{3} \mathrm{~m}^{3} \\
\end{array}$ & & $\begin{array}{r}1988 \\
\times 10^{3} \mathrm{~m}^{3} \\
\end{array}$ & $\begin{array}{r}2004 \\
\times 10^{3} \mathrm{~m}^{3} \\
\end{array}$ \\
\hline 1 & 6.7 & & 0.6 & 2.8 & & 3.7 & & 1.8 & 0.9 \\
\hline 2 & 24.1 & & 2.4 & 5.2 & & 8.9 & & 8.8 & 2.6 \\
\hline 3 & 37.6 & & 6.3 & 9.4 & & 18.0 & & 14.1 & 3.5 \\
\hline 4 & 54.0 & & 15.8 & 12.5 & & 27.8 & & 23.2 & 5.5 \\
\hline 5 & 48.6 & & 23.6 & 14.5 & & 35.8 & & 86.5 & 6.9 \\
\hline \multicolumn{10}{|c|}{ Mangakiore Catchment A } \\
\hline $\begin{array}{c}\text { Nested } \\
\text { Catchment }\end{array}$ & & $\begin{array}{r}1949 \\
\times 10^{3} \mathrm{~m}^{3} \\
\end{array}$ & & $\begin{array}{r}1965 \\
\times 10^{3} \mathrm{~m}^{3} \\
\end{array}$ & $\begin{array}{r}\mathbf{1 9 7 4} \\
\times 10^{3} \mathrm{~m}^{3} \\
\end{array}$ & & & $\begin{array}{r}1988 \\
\times 10^{3} \mathrm{~m}^{3} \\
\end{array}$ & $\begin{array}{r}\mathbf{2 0 0 4} \\
\times 10^{3} \mathrm{~m}^{3} \\
\end{array}$ \\
\hline 1 & & 1.5 & & 28.3 & 18.8 & & & 36.5 & 0.8 \\
\hline 2 & & 3.1 & & 38.3 & 35.2 & & & 50.7 & 0.9 \\
\hline 3 & & 7.3 & & 52.2 & 43.3 & & & 92.0 & 6.1 \\
\hline 4 & & 23.9 & & 81.5 & 66.4 & & & 148.3 & 14.2 \\
\hline 5 & & 34.8 & & 88.6 & 75.0 & & & 195.5 & 17.3 \\
\hline \multicolumn{10}{|c|}{ Mangakiore Catchment B } \\
\hline $\begin{array}{c}\text { Nested } \\
\text { Catchment }\end{array}$ & & $\begin{array}{r}1949 \\
\times 10^{3} \mathrm{~m}^{3}\end{array}$ & & $\begin{array}{r}\mathbf{1 9 6 5} \\
\times 10^{3} \mathrm{~m}^{3}\end{array}$ & $\begin{array}{r}\mathbf{1 9 7 4} \\
\times 10^{3} \mathrm{~m}^{3}\end{array}$ & & & $\begin{array}{l}\mathbf{1 9 8 8} \\
\times 10^{3} \mathrm{~m}^{3}\end{array}$ & $\begin{array}{l}2004 x \\
10^{3} \mathrm{~m}^{3}\end{array}$ \\
\hline 1 & & 3.2 & & 9.4 & 3.9 & & & 10.9 & 0.1 \\
\hline 2 & & 9.4 & & 15.4 & 6.5 & & & 18.9 & 0.5 \\
\hline 3 & & 10.8 & & 31.7 & 7.8 & & & 29.1 & 0.9 \\
\hline 4 & & 23.1 & & 39.2 & 8.3 & & & 44.0 & 3.8 \\
\hline 5 & & 33.5 & & 49.1 & 9.4 & & & 64.5 & 8.7 \\
\hline
\end{tabular}




\subsubsection{Sediment Delivery Ratios}

Overall, while there was a large variation for the sediment delivery ratios derived across the five catchments, most of the sediment delivery ratios were under $30 \%$ (Table 5.5). The Waimoa catchment had the highest sediment delivery ratio of $49.8 \%$ but the average ratio for the entire catchment was only $16.9 \%$. The average sediment delivery ratios for the entire Ahioteatua Catchment A and B were comparable at $16.7 \%$ and $17 \%$ respectively. Within the Mangakiore Catchment A and B the average sediment delivery ratio for the entire catchments were $16.3 \%$ and $15.8 \%$ respectively. The spatial and temporal patterns in the sediment delivery ratios given below are displayed in the following sections of this chapter. 
Table 5.5 Sediment Delivery Ratios for each nested catchment within the Waimoa, Ahioteatua and Mangakiore Catchments.

\begin{tabular}{|c|c|c|c|c|c|c|c|c|c|}
\hline \multicolumn{10}{|c|}{ Waimoa Catchment } \\
\hline $\begin{array}{c}\text { Nested } \\
\text { Catchment }\end{array}$ & & & $\begin{array}{c}1952 \\
(\%)\end{array}$ & $\begin{array}{c}1965 \\
(\%)\end{array}$ & $\begin{array}{c}\mathbf{1 9 7 4} \\
(\%)\end{array}$ & $\begin{array}{c}1980 \\
(\%)\end{array}$ & $\begin{array}{c}1984 \\
(\%)\end{array}$ & & $\begin{array}{c}2004 \\
(\%)\end{array}$ \\
\hline 1 & & & 15.4 & 23.4 & 20.7 & 25.6 & 22.8 & & 22.3 \\
\hline 2 & & & 17.5 & 40.1 & 27.8 & 25.0 & 23.0 & & 22.3 \\
\hline 3 & & & 24.2 & 32.3 & 49.8 & 37.6 & 26.2 & & 29.9 \\
\hline 4 & & & 21.2 & 31.0 & 24.1 & 24.7 & 24.5 & & 22.9 \\
\hline 5 & & & 15.4 & 31.6 & 17.3 & 18.4 & 16.9 & & 17.2 \\
\hline \multicolumn{10}{|c|}{ Ahioteatua Catchment A } \\
\hline $\begin{array}{c}\text { Nested } \\
\text { Catchment }\end{array}$ & $\begin{array}{c}1943 \\
(\%)\end{array}$ & & $\begin{array}{c}1952 \\
(\%)\end{array}$ & $\begin{array}{c}\mathbf{1 9 6 9} \\
(\%)\end{array}$ & & $\begin{array}{c}1982 \\
(\%)\end{array}$ & & $\begin{array}{c}\mathbf{1 9 8 8} \\
(\%)\end{array}$ & $\begin{array}{c}2004 \\
(\%)\end{array}$ \\
\hline 1 & 21.3 & & 24.4 & 23.2 & & 25.4 & & 26.3 & 15.5 \\
\hline 2 & 23.2 & & 24.9 & 25.4 & & 24.7 & & 25.8 & 17.8 \\
\hline 3 & 22.6 & & 24.7 & 25.0 & & 24.3 & & 25.6 & 17.3 \\
\hline 4 & 21.9 & & 24.7 & 24.8 & & 24.5 & & 18.0 & 15.9 \\
\hline 5 & 16.8 & & 18.3 & 18.6 & & 18.4 & & & 11.6 \\
\hline \multicolumn{10}{|c|}{ Ahioteatua Catchment B } \\
\hline $\begin{array}{c}\text { Nested } \\
\text { Catchment }\end{array}$ & $\begin{array}{c}1943 \\
(\%)\end{array}$ & & $\begin{array}{c}1952 \\
(\%)\end{array}$ & $\begin{array}{c}1969 \\
(\%)\end{array}$ & & $\begin{array}{c}1982 \\
(\%)\end{array}$ & & $\begin{array}{c}\mathbf{1 9 8 8} \\
(\%)\end{array}$ & $\begin{array}{c}2004 \\
(\%)\end{array}$ \\
\hline 1 & 23.2 & & 13.5 & 19.0 & & 24.8 & & 12.1 & 14.0 \\
\hline 2 & 23.9 & & 17.8 & 19.8 & & 33.7 & & 23.1 & 15.1 \\
\hline 3 & 23.4 & & 19.5 & 19.7 & & 37.8 & & 18.4 & 13.6 \\
\hline 4 & 22.9 & & 20.8 & 17.8 & & 39.6 & & 19.3 & 14.5 \\
\hline 5 & 16.4 & & 15.8 & 14.8 & & 17.4 & & 28.0 & 11.4 \\
\hline \multicolumn{10}{|c|}{ Mangakiore Catchment A } \\
\hline $\begin{array}{c}\text { Nested } \\
\text { Catchment }\end{array}$ & & $\begin{array}{c}1949 \\
(\%)\end{array}$ & & $\begin{array}{c}1965 \\
(\%)\end{array}$ & $\begin{array}{c}1974 \\
(\%)\end{array}$ & & & $\begin{array}{c}\mathbf{1 9 8 8} \\
(\%)\end{array}$ & $\begin{array}{c}2004 \\
(\%)\end{array}$ \\
\hline 1 & & 16.6 & & 24.3 & 26.0 & & & 26.0 & 18.7 \\
\hline 2 & & 17.5 & & 23.5 & 26.0 & & & 25.6 & 17.8 \\
\hline 3 & & 18.6 & & 23.7 & 25.8 & & & 25.8 & 20.3 \\
\hline 4 & & 21.3 & & 22.3 & 24.8 & & & 25.8 & 20.0 \\
\hline 5 & & 16.1 & & 15.6 & 18.7 & & & 19.5 & 12.6 \\
\hline \multicolumn{10}{|c|}{ Mangakiore Catchment B } \\
\hline $\begin{array}{c}\text { Nested } \\
\text { Catchment }\end{array}$ & & $\begin{array}{c}1949 \\
(\%)\end{array}$ & & $\begin{array}{c}1965 \\
(\%)\end{array}$ & $\begin{array}{c}\mathbf{1 9 7 4} \\
(\%)\end{array}$ & & & $\begin{array}{c}\mathbf{1 9 8 8} \\
(\%)\end{array}$ & $\begin{array}{c}2004 \\
(\%)\end{array}$ \\
\hline 1 & & 23.8 & & 24.4 & 23.3 & & & 25.0 & 18.9 \\
\hline 2 & & 23.5 & & 24.1 & 23.2 & & & 24.8 & 21.0 \\
\hline 3 & & 23.5 & & 24.9 & 23.3 & & & 25.1 & 21.2 \\
\hline 4 & & 23.7 & & 19.8 & 22.7 & & & 25.3 & 20.2 \\
\hline 5 & & 18.7 & & 12.7 & 16.4 & & & 18.1 & 15.4 \\
\hline
\end{tabular}


However, the landslide rate under forest (exotic and indigenous) is about ten times less than under pasture (Hicks, 1991; Marden and Rowan, 1994; De Rose, 1996; and Page and Trustrum, 1997). A 50\% reduction in landslide derived sediment could be achieved through stabilization of the hillslopes due to reforestation of $12 \%$ of the Waipaoa catchment, which is susceptible to landslides (Reid and Page, 2002). Due to the rate of reforestation since 1988, a storm of Cyclone Bola magnitude storm is predicted to generate $15 \%$ less landslide derived sediment within the current Waipaoa catchment (Page et al., 1999). Both Ahioteatua catchment A and Mangakiore catchment B were partially reforested in commercial plantations in the 2004 aerial photography. This has the potential to skew the sediment delivery ratio as the outlet of Ahioteatua catchment A is forested and therefore failures are less likely to occur in this part of the catchment which often has lower drainage density and a higher percentage of disconnected earthflows compared to the rest of the catchment. In Mangakiore catchment B the upper half of the headwaters is covered in commercial forestry and therefore unlikely to have a high density of failures. In this area, the slopes are often steeper and the fluvial density is higher giving a higher percentage of connected earthflows. Consequently, the 2004 catchment sediment delivery ratios for the Ahioteatua A and Mangakiore B catchments may not be comparable to the earlier years.

\subsection{Spatial Patterns in Sediment Delivery Ratios}

The following fitted trend lines and correlations are taken from the above sediment delivery ratio data for each nested catchment. Overall, every catchment displays a decrease in the sediment delivery ratio as catchment size increases. In the Waimoa catchment the 1952 and 1984 aerial photos display the strongest correlations in this pattern (Figure 5.3). The 1965 aerial photos show a reverse in the expect trend where sediment delivery ratios increases as catchment size increases and there is a moderate correlation for this fitted trend line. However, the correlation for this line is very low. In the Ahioteatua Catchment A the 1982 and 1988 aerial photos display the strongest correlations (Figure 5.4). In the Ahioteatua Catchment B the 1969 aerial photo displays the strongest correlation. However, the 1988 aerial photo shows a reverse in this trend 
(Figure 5.5). In Mangakiore Catchment A again, while four of the aerial photos display the expected pattern of sediment delivery ratios decreasing with increasing catchment area, the 1949 photo displays the reverse. However, the correlation for the 1949 fitted trend line is extremely low. In comparison the correlation for the 1965, 1974 and 1988 trend lines are stronger (Figure 5.6). For Mangakiore Catchment B all the aerial photos display a lowering of the sediment delivery ratio as catchment size increases. The correlation for these fitted trend lines are also very strong (Figure 5.7).

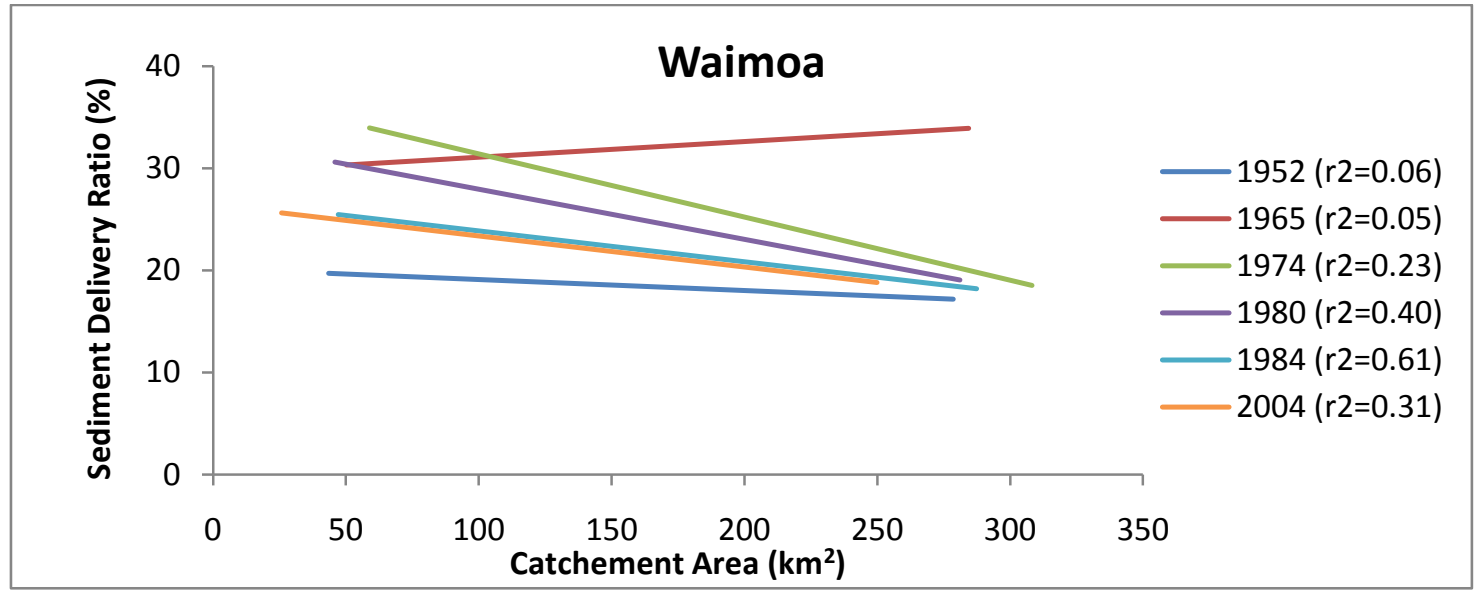

Figure 5.3 Spatial patterns to sediment delivery ratios in Waimoa catchment A.

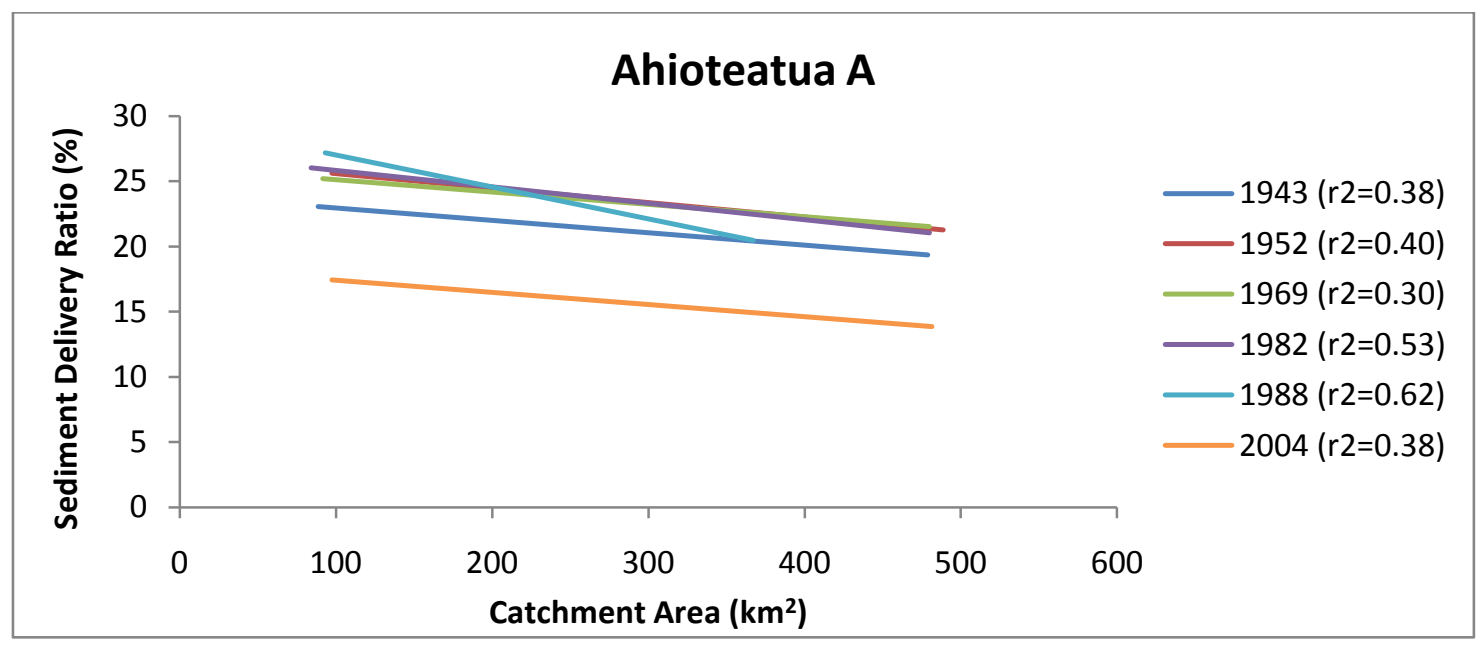

Figure 5.4 Spatial patterns to sediment delivery ratios in Ahioteatua catchment A. 


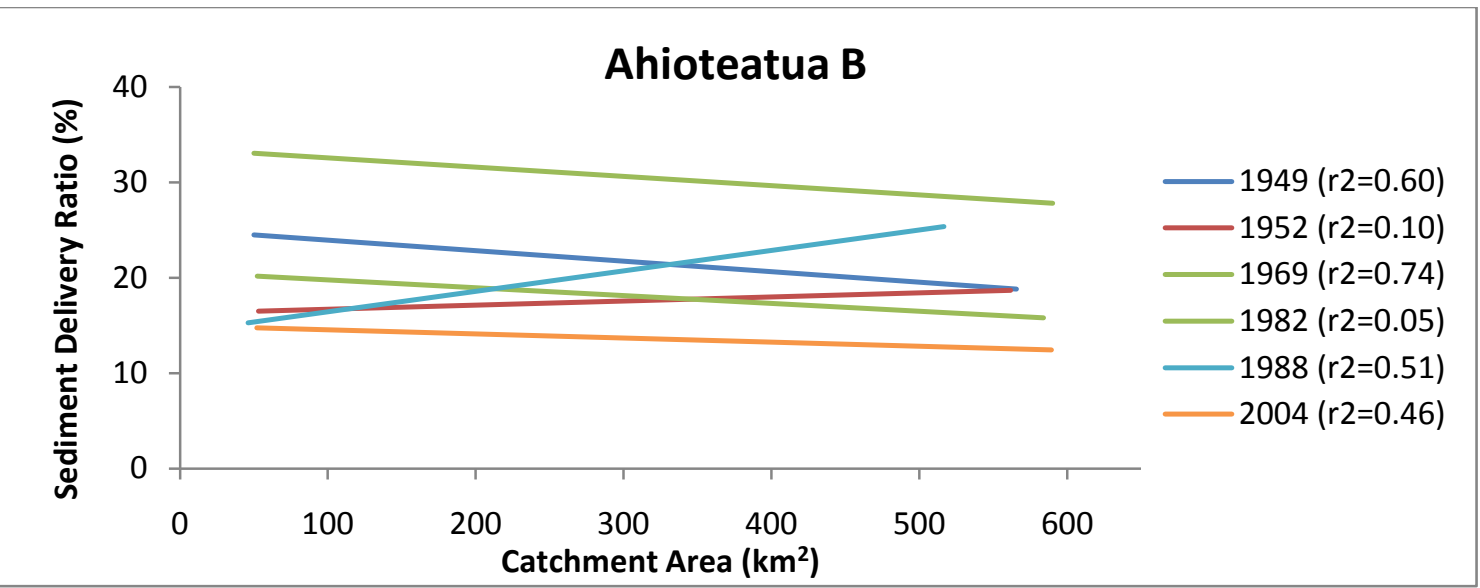

Figure 5.5 Spatial patterns to sediment delivery ratios in Ahioteatua catchment B.

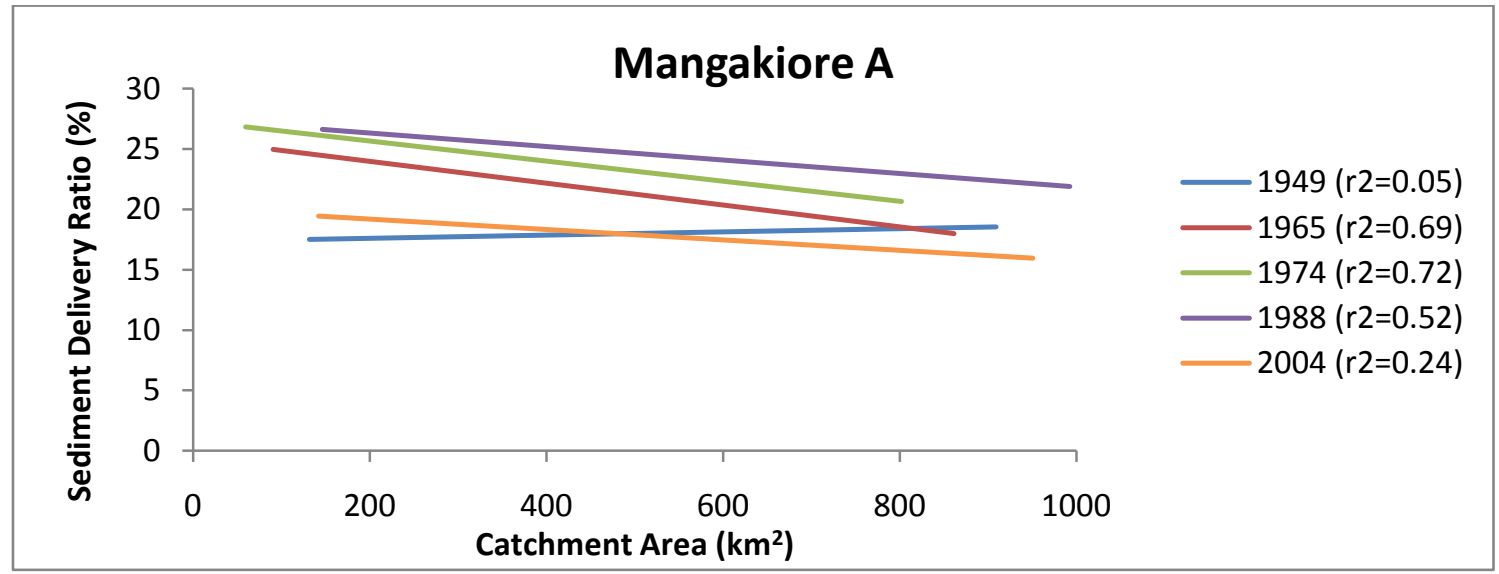

Figure 5.6 Spatial patterns to sediment delivery ratios in Mangkiore catchment A.

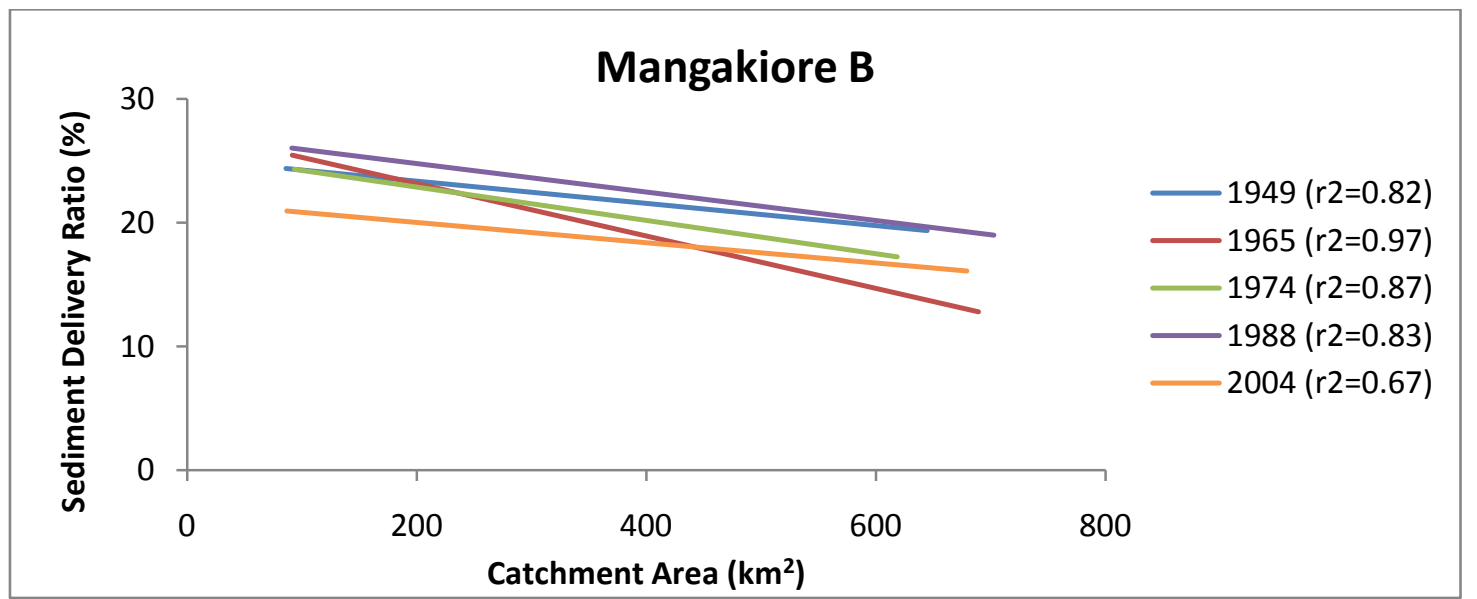

Figure 5.7 Spatial patterns to sediment delivery ratios in Mangakiore catchment B. 


\subsection{Temporal Patterns in Sediment Delivery Ratios}

Again, the following fitted trend lines and correlations are taken from the sediment delivery ratio data given in section 5.3.4. for each nested catchment. Overall, there is no consistent trend between the five catchments. In the Waimoa catchment Sub-catchment One and Catchment Five (representing the entire catchment) have the highest correlations and display a pattern of increasing sediment delivery ratios over time (Figure 5.8). In Ahioteatua Catchment A, all the nested catchments display the expected trend of decreasing sediment ratios with increasing time. For this catchment, the correlations were strongest in Sub-catchment Four and Catchment Five (Figure 5.9). In Ahioteatua Catchment B all the Sub-catchments display the pattern of decreasing sediment delivery ratio. But Catchment Five displays the opposite pattern. Nevertheless, in Ahioteatua Catchment B the correlation for the fitted trends lines are very low (Figure 5.10). In Mangakiore Catchment A, the three smaller nested catchments all display increasing sediment delivery ratios where as the larger catchments display a decrease in sediment delivery over time (Figure 5.11). In Mangakiore Catchment B all the Sub-Catchments display a decrease in sediment delivery over time and Catchment Five shows no change (Figure 5.12). In both these catchments Sub-catchment One has the highest correlation values, but generally the correlation values were low to very low.

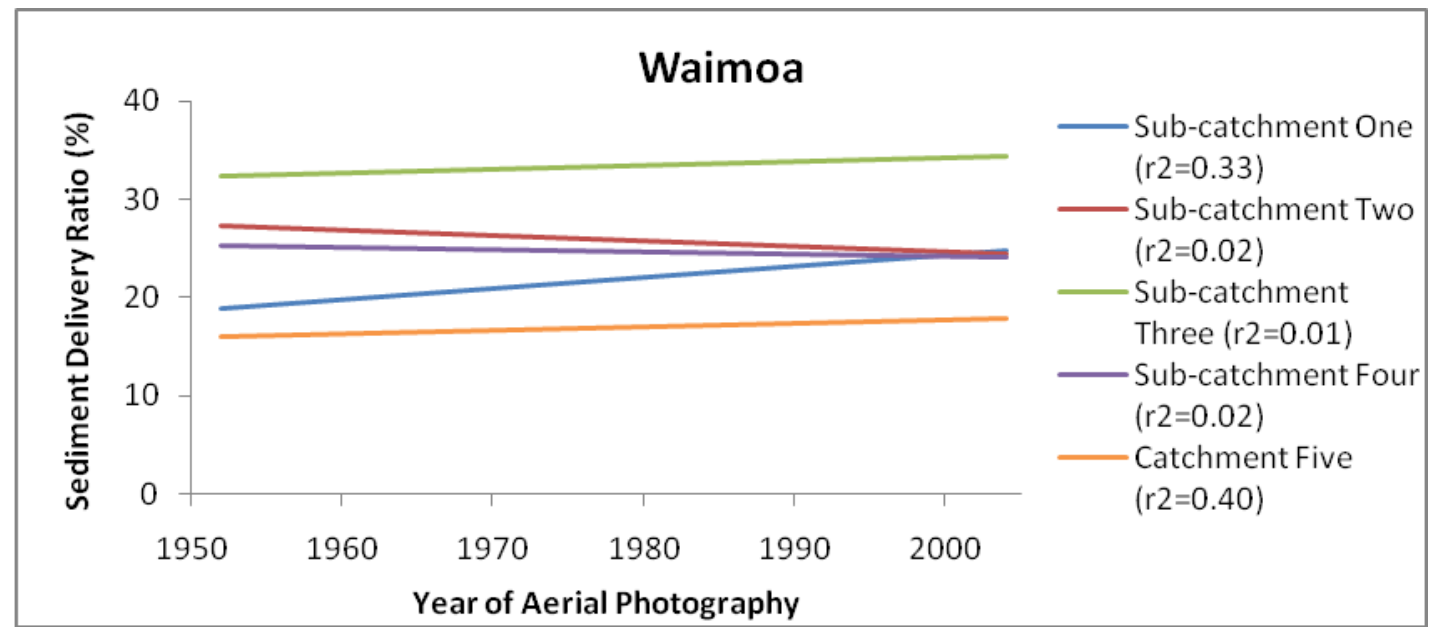

Figure 5.8 Temporal patterns in sediment delivery ratios for Waimoa catchment A. 


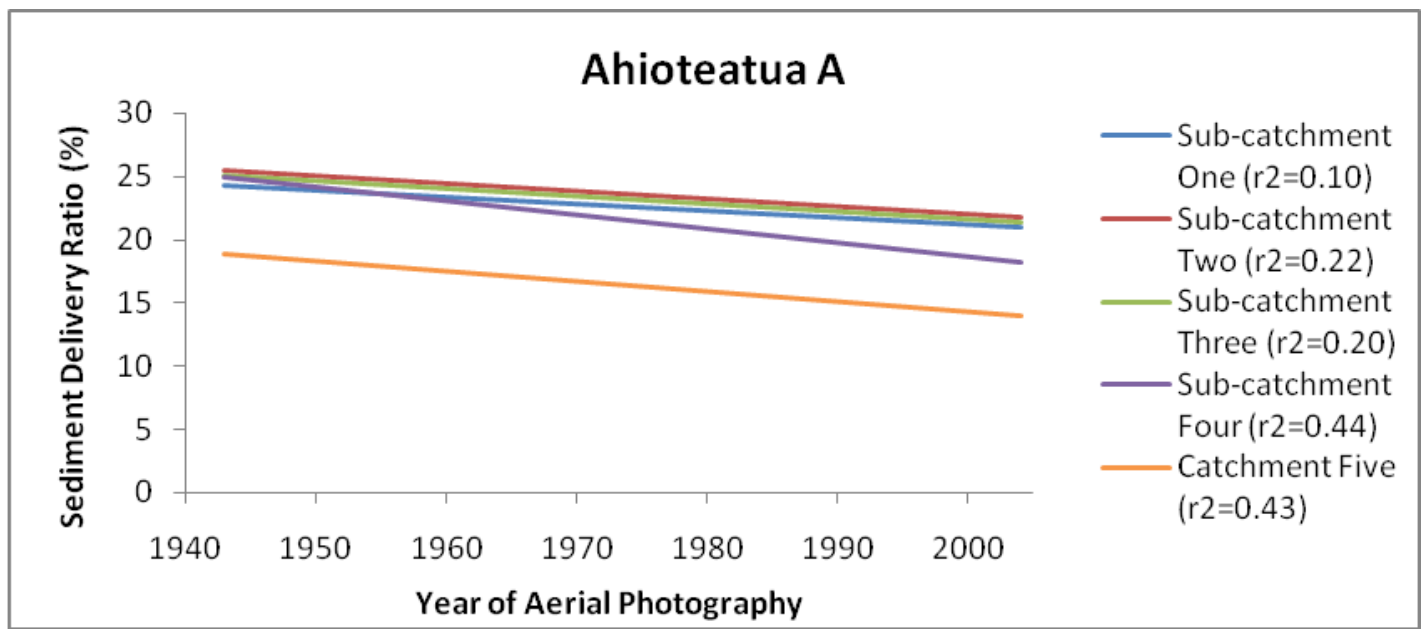

Figure 5.9 Temporal patterns in sediment delivery ratios for Ahioteatua catchment A.

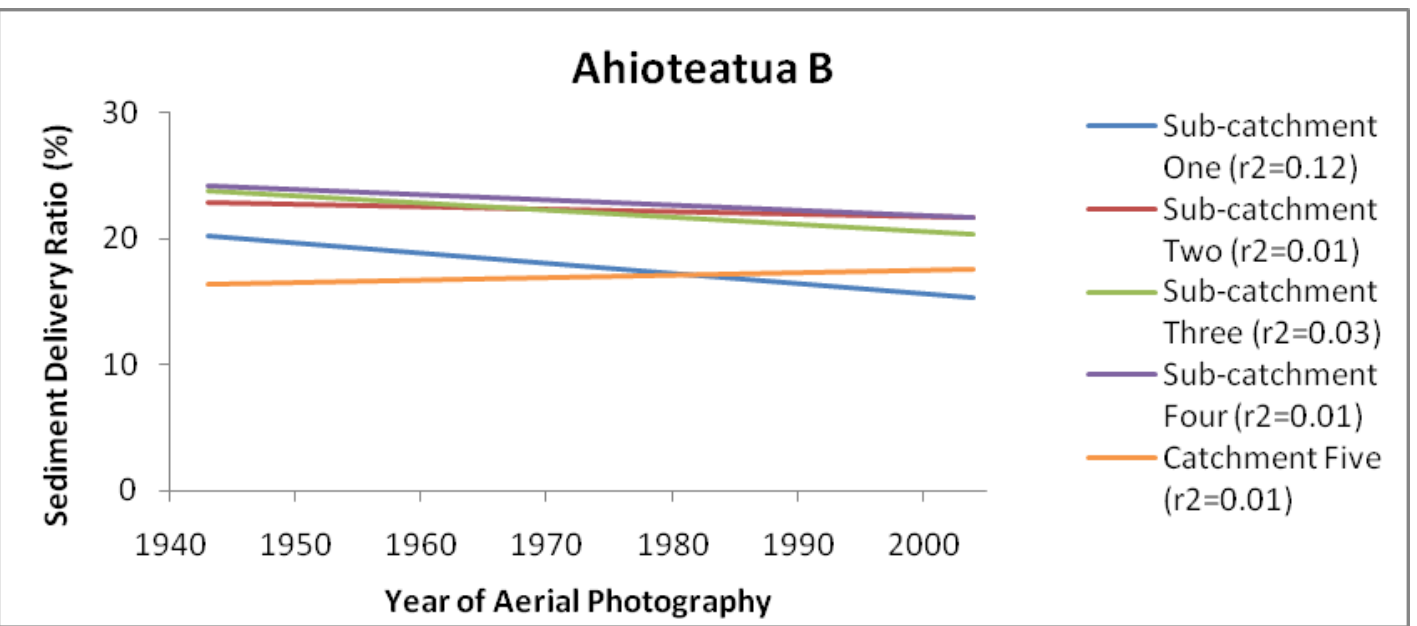

Figure 5.10 Temporal patterns in sediment delivery ratios for Ahioteatua catchment

B.

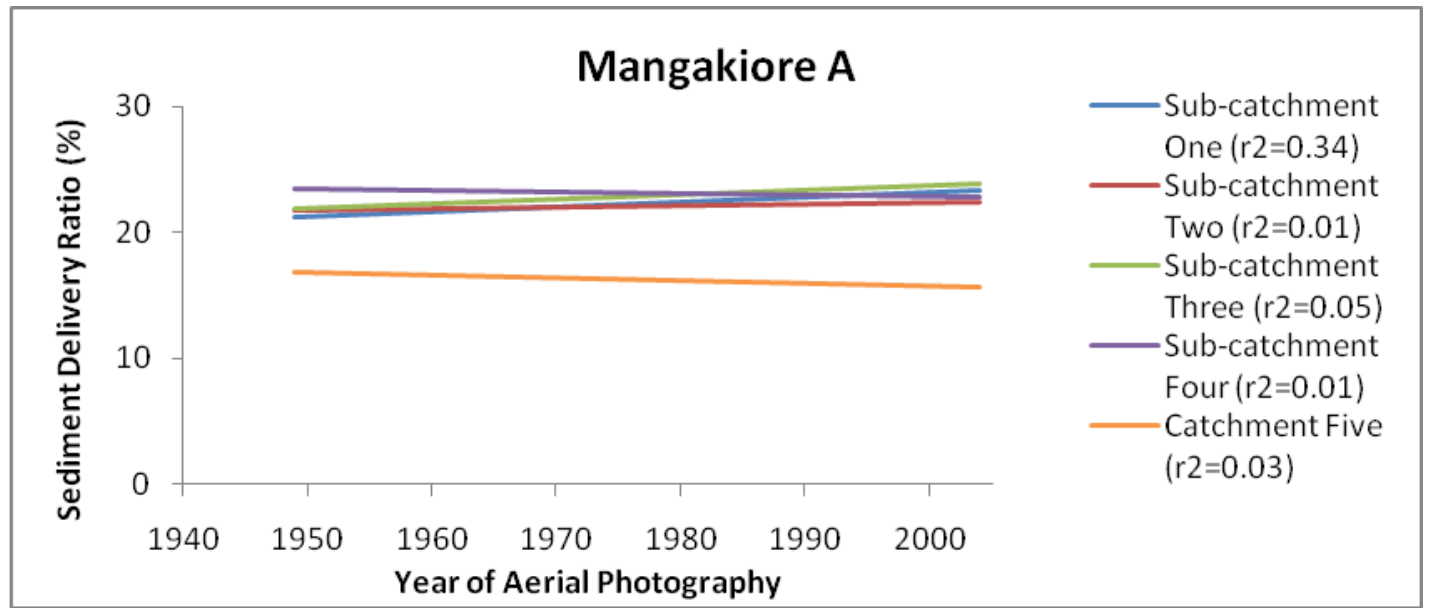

Figure 5.11 Temporal patterns in sediment delivery ratios for Mangakiore catchment A. 


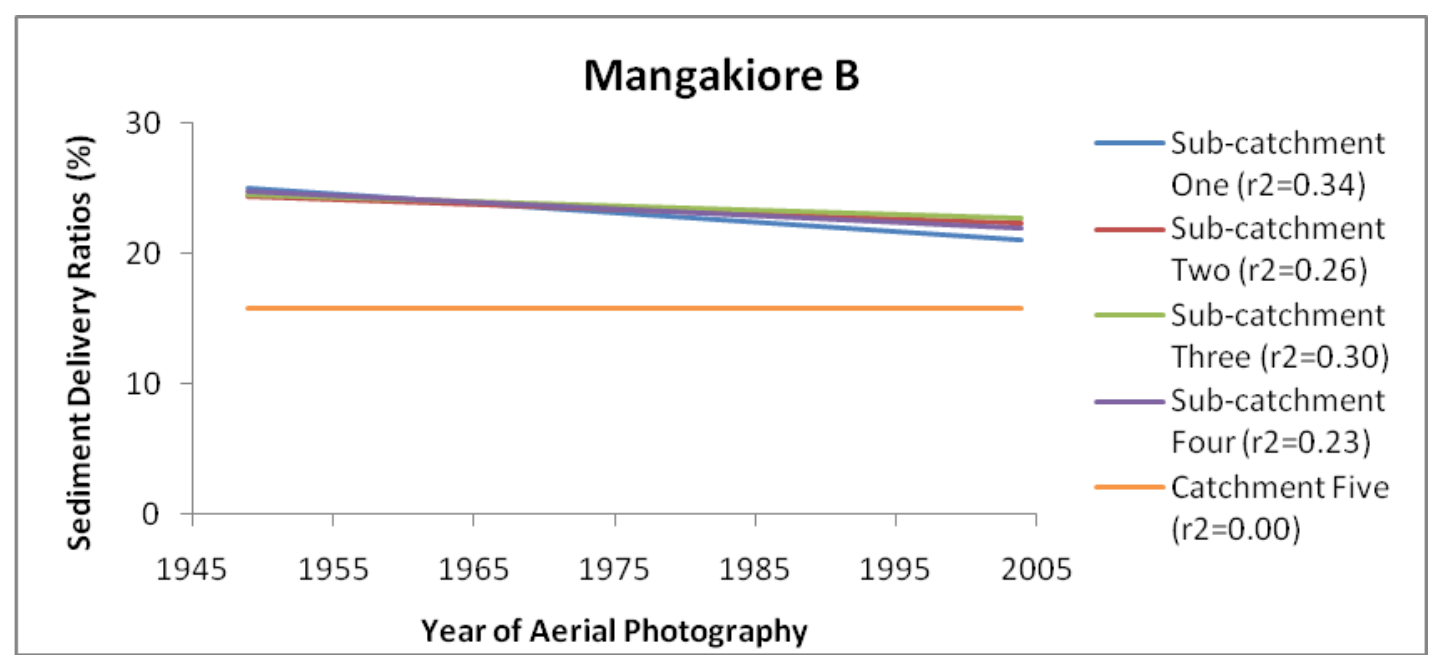

Figure 5.12 Temporal patterns in sediment delivery ratios for Mangakiore catchment B.

\subsection{Summary}

This chapter has presented spatial and temporal trends in sediment delivery ratios. The overall pattern of the catchment sediment delivery ratios is to decrease as catchment size increases. This is observed across all the field sites used in this thesis. However, the temporal pattern of sediment delivery ratios is not clear. The strongest trends were observed in the Ahioteatua Catchment B, where the catchment sediment delivery ratio decreased over time. However, this was not consistent throughout the other catchments. The absence of a consitient temporal pattern to sediment delivery relates to the random nature of failure location over time. The inability to observe a consistent pattern to failure location on the hillslope in relation to the channel network in this research is addressed in the following chapter. Further discussion on observed patterns in the sediment delivery graphs above is also given in the following chapter. 


\section{Chapter Six: Evolution of Sediment Delivery and its Implications for Determining Ratios in the Waipaoa Catchment}

\subsection{Introduction}

The results of this thesis were presented in the previous chapter which highlighted the common notion that sediment delivery is a complex process which is not easily defined or predicted. This chapter discusses the meaning of the results and their validity. It also provides an explanation for why no consistent temporal trends were observed across the five sub-catchments within the Waipaoa Catchment. The first section of this chapter briefly addresses the limitations to modelling sediment delivery ratios and explores other variables which were not utilized in this research. The second section of this chapter discusses the hypothesis, where importance is placed on the distance of the earthflow from the channel and the evolution of this through time. The third section of this chapter summarises the patterns both expected and observed from this research and interprets them in the context of the evolutionary stages of the Crozier and Preston (1999) Terrain Event-Resistance Model. The concluding section then outlines two different approaches to applying the results derived in this thesis for estimating sediment delivery ratios for the Waipaoa catchment and incorporating these patterns into numerical modelling.

\subsection{Limitations of the Ability to Predict Sediment Delivery}

The original objective of aim one was to develop a predictive regression equation for off-slope sediment delivery. The model was to incorporate the physical properties of the failed material and the morphometric properties of the runout paths. However, extremely low correlations between the variables resulted in a regression equation with an extremely low level of explanation of the variation in delivery. Thus, the conclusion can be drawn that sediment delivery is a complex process, and that little reliance can be 
placed on modelling using simple regression analysis of morphometric properties. Instead, it is suggested that variables which account for the internal properties of the debris flow need to be included to develop a more reliable model.

Internal properties of the earthflow, such as the moisture content of the soil at the time of failure, are hard to observe empirically and even harder to predict in the natural system. Yet they are vital to develop the desired result of an accurate predictive model of sediment delivery ratios. They influence the style and length of debris tail runout (Figure 6.1) and allow the mobilised sediment to be transported off-slope. Moisture content at the time of failure is especially important but this is difficult to incorporate as it cannot be determined accurately after the event.
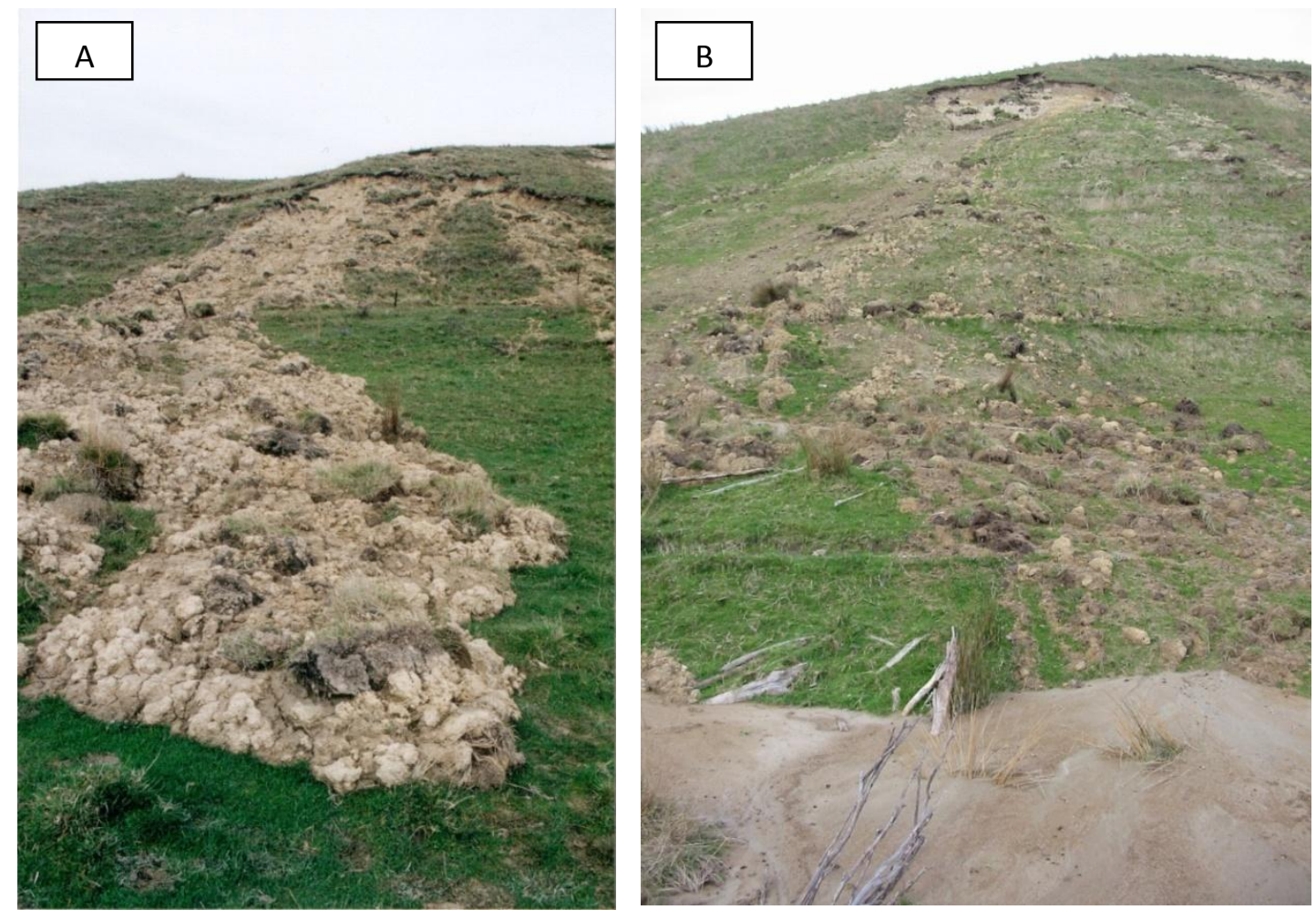

Figure 6.1 Differences in debris flows from Hinenui earthflows triggered in the 2002 storm event. A) The lower moisture content in this debris tail has resulted in it moving as a uniform mass downslope, whereas in B) the higher moisture content in this earthflow, resulting from a tunnel exposed perpendicular to the crown on scar, has transported the finer sediment much further downslope. (Photos: N. Preston, 2002). 


\subsection{The Importance of Scar Distance from the Channel}

The underlying rationale for the hypothesis developed for this thesis was the importance of the distance between earthflow scars and the fluvial network. When earthflows are located adjacent to the channels (either the ephemeral channels present during the storm event or the main stream in the catchment) then the potential for connectivity is high and associated off-slope sediment delivery can also assumed to be high. However, a change in the location of the failures, and in particular upslope retreat of scars, modifies this relationship. If a larger percentage of the scars are located further from the channel then the potential for connectivity decreases. While the distance sediment has to travel downslope before entering the fluvial network increases, the average runout distance is unlikely to increase to the same extent. Therefore, the potential for connectivity decreases and overall catchment sediment delivery ratios might be expected to decrease. As a consequence, the distance between the earthflows and the channel is expected to be an important factor, as is the change in this distance over time.

If earthflows do migrate upslope over time then there should be a corresponding decrease in the overall connectivity in the catchment. In Figures 6.2-6.6 the cumulative percentage of scars within a given distance of the channel network is plotted for each of the study catchments. If upslope migration of scar locations were occurring, this would be evident as a regular downward progression in the curves. Such a pattern of upslope retreat of the landslides is not clearly observed in the five field site catchments. Instead, scar locations observed in the aerial photos move both closer and further away from the channel over the time period examined. Hence, it could be appropriate to say there is no consistently predictable pattern to scar location over time. 


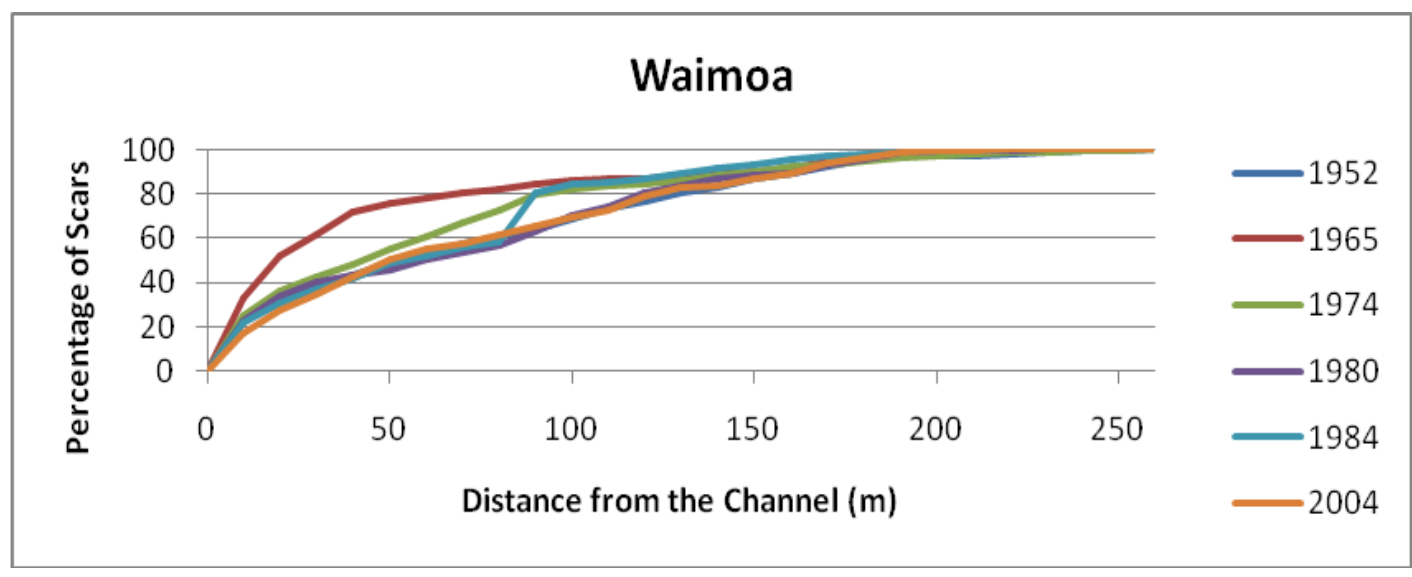

Figure 6.2 Changes in the location of earthflow scars in relation to the fluvial network for each aerial photo in the Waimoa Catchment.

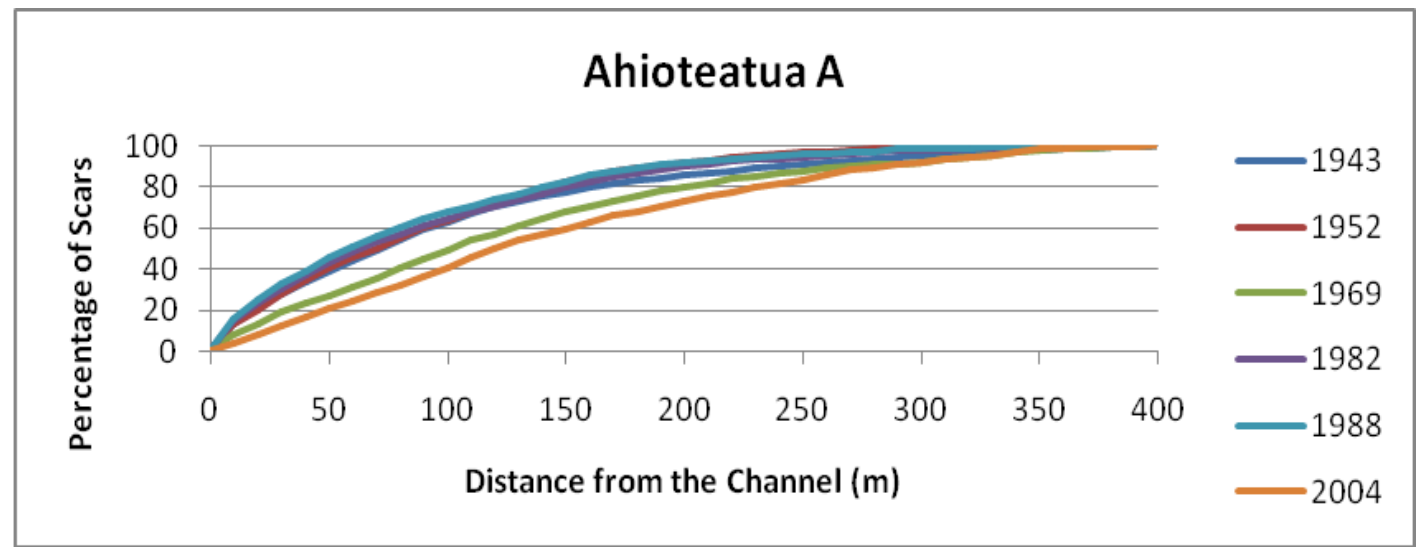

Figure 6.3 Changes in the location of the observed earthflow scars in relation to the fluvial network for each aerial photo in Ahioteatua Catchment A.

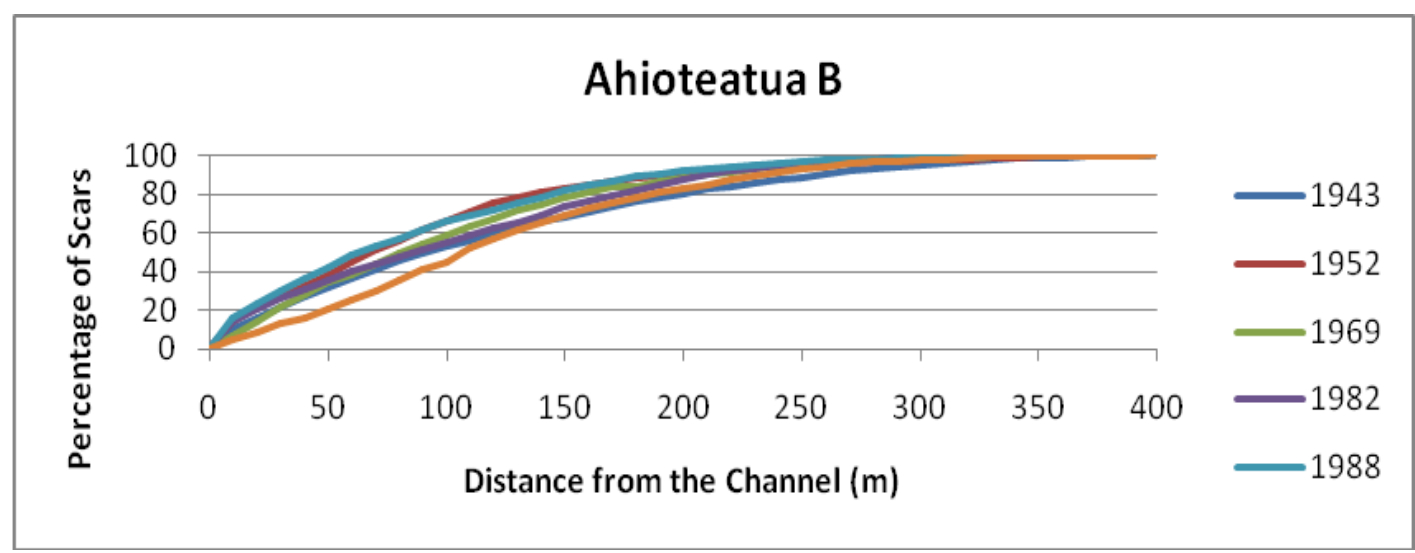

Figure 6.4 Changes in the location of the observed earthflow scars in relation to the fluvial network for each aerial photo in Ahioteatua Catchment B. 


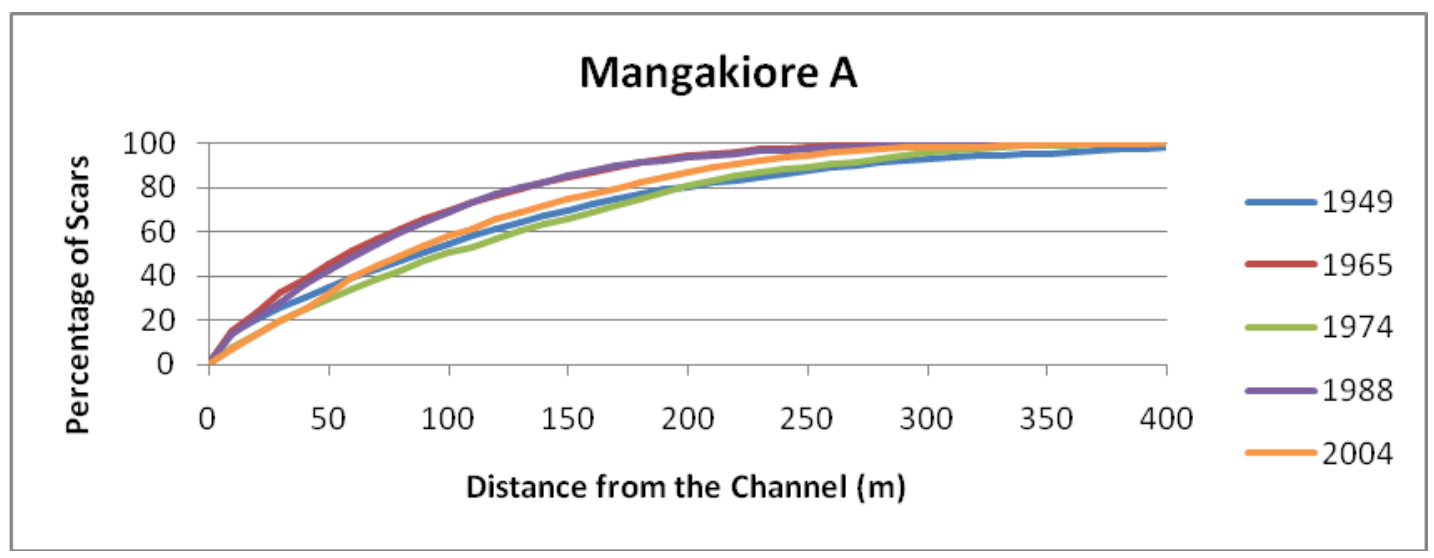

Figure 6.5 Changes in the location of the observed earthflow scars in relation to the fluvial network for each aerial photo in Mangakiore Catchment A.

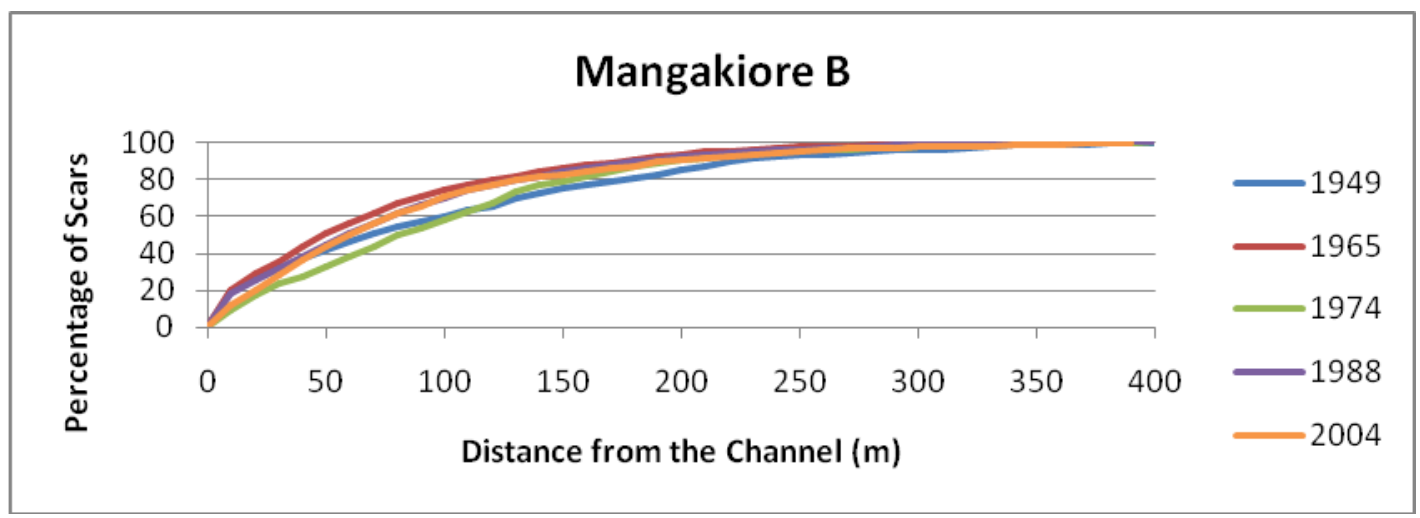

Figure 6.6 Changes in the location of the observed earthflow scars in relation to the fluvial network for each aerial photo in Ahioteatua Catchment B.

\subsection{Changes in Sediment Delivery over Time}

Upslope retreat of failure location has been linked to the notion of regolith exhaustion and evolving thresholds for landslide initiation (Crozier and Preston, 1999; Brooks et. $a l ., 2002)$. This has been hypothesised here to result in significant changes to catchment sediment delivery ratios for earthflows, with the percentage of connected scars decreasing as the failure zone moves further away from the lower slopes which are fluvially connected and towards the ridgeline where regolith depth is also reduced. Hence the catchment sediment delivery ratio might be expected to decrease in time 
following these changes. However, as discussed above, no consistent temporal trend in scar location was identified across the five study catchments. A general discussion of these findings and an interpretation is given below.

\subsubsection{Landslide location and Upslope Migration}

The scar base is unlikely to be consistently at the regolith bedrock interface across all three land systems as while the average soil depth is likely to be less than $100 \mathrm{~cm}$, the average scar depth for failure generated in Cyclone Bola is $76 \mathrm{~cm}$ across these systems (Page et al., 1999). This allows these older scars to become reactivated in the next landslide event, rather than a new scar forming above the previous scar's crown. Soil recovery rates within scars are also fast for the East Cape region (Smale et. al., 1997). The production of new soil, by biological activity and surface weathering, creates new material prone to failure within the old scar. Nevertheless, the reactivation of old scars is not a sustainable process as soil recovery rates cannot recreate the critical depth for failure within a scar before the next storm event. Therefore new failures must be occurring elsewhere on the slope.

It is also generally common for the wetter and shaded southern facing slopes to be more affected by mass movement failures. However, Owen (1981) suggests that the sunnier and drier northern slopes are often more desiccated. This means they have higher infiltration rates during intensive rainfall events which make them more vulnerable to rainfall induced slope failure. Such a preference for the northern facing slopes could also be due to the removal of regolith from previous earthflow generating events on the wetter southern slopes as observed by Crozier et al. (1980). This inclination for failure on the north facing slopes was seen with the 2004 storm event which affected the Manawatu and Wairarapa regions in the lower North Island of New Zealand (Hancox and Wright, 2005). In this thesis comparison of cumulative scar aspect was a technique employed to observe changes in scar location between the aerial photos since rectification of the photos did not allow for an overlay analysis of scars. Data on scar 
aspect and size for each catchment is given in Appendix D. Storm history for each catchment is given in Appendix E.

At least eight multiple occurrence failure events are assumed to have affected the Wharekopae field site and scars were measured from six sets of sequential aerial photography in the Waimoa catchment. Yet there are no consistent properties between these six datasets. The total number of scars, average dimensions, position and aspect on the hillslope, and catchment sediment delivery ratio are different for all the datasets. This pattern is repeated in the Te Arai field site where nine multiple occurrence events are assumed to have affected the area and scars were measured from five sets of sequential aerial photography. The Waihora field site is slightly different. Here twelve multiple occurrence failure events are assumed to have affected the Ahioteatua catchments and scars were measured off six sequential aerial photos. While scar properties and catchment sediment delivery ratios varied between photos, there was a general trend of decreasing number of failures and total area of catchment affected, which lends support to the notion of regolith exhaustion for these catchments. Failures also generally occurred on slopes of similar aspect between the photographs. However, careful consideration needs to be taken when using patterns in scar aspect to support the notion of regolith exhaustion.

While consistency of scar aspect over time would be expected if scars are moving upslope, this observation alone does not prove that this is occurring; scars could be occurring on similar aspects but in different parts of the hillslope. Conversely, lack of consistency in the aspect of scars over time would not disprove upslope migration; depending on the configuration of the slopes relative to the channel, some slopes may become exhausted more rapidly than others, such that a change in modal aspect reflects this rather than the absence of upslope migration. Yet, when scar aspect patterns were similar between photos (Appendix D), then the pattern to scar location between photos was also similar. For example, Waimoa (1980 \& 2004), Ahioteatua A (1942, 1982 \& 1988), Ahioteatua B (1952 \& 1988), Mangakiore A (1965 \& 1988; 1949 \& 1974) and Mangakiore B (1965, 1988 \& 2005; $1949 \&$ 1974). This suggests scar locations 
(Appendix D) are similar for the above years, possibly due to similar storm directions which have affected particular slopes. This may explain why scar retreat is not an easily observed phenomenon since scars location strongly mirrors storm direction. Hence scar retreat may only be observed in catchments with a uniform storm history. So while changes in distance of scars from the channel is the simplest variable to explore in seeking a pattern, and as Figures 6.2-6.6 indicate, it is too simplistic a variable as a pattern is not consistently observed.

\subsubsection{Trajectories of Catchment Evolution}

Hence, catchment evolution is a complex phenomenon, and adds a further layer of complexity to the determination of sediment delivery ratios, in addition to those described by Walling (1983; see Chapter 2). Scars cannot necessarily be expected to simply retreat upslope as the catchment adjusts to human modification of the dominant vegetation cover. Instead, failure patterns are a complex outcome of geomorphological behaviour over time as the catchment moves towards a new stable phase. Therefore, patterns in the associated sediment delivery ratios for these earthflows could still be expected to reflect catchment evolution. But this relationship is not straight forward and cannot be explained by consistent upslope retreat of the scar crowns. Instead, the system needs to be considered as constantly evolving and landscapes viewed in terms of the Crozier and Preston (1999) relaxation curve.

Following deforestation in the late $19^{\text {th }}$ and early $20^{\text {th }}$ Centuries the Waipaoa catchment underwent an extreme and well defined adjustment in terrain resistance. The removal of indigenous vegetation would have been accompanied by a significant decrease in the triggering threshold for earthflows, allowing for enhanced erosional activity. A hypothesised result of this is a subsequent increase in the triggering threshold due to regolith stripping and bedrock exposure as the catchment moves towards a regolith exhaustion phase (Crozier and Preston, 1999). However, this adjustment towards the new more stable phase is interrupted by a secondary adjustment phase where colluvial 
deposits of earthflow derived debris on the lower slopes become prone to failure, lowering the triggering threshold once again (Brooks et al., 2002).

When considered in this context, the failure of the study sites to show the expected pattern of upslope retreat of the scars can be seen as not entirely unexpected. While there may have been a spatial pattern to the location of failure in the decades immediately following deforestation, this cannot be tested in this thesis. The time period covered by aerial photography used for observing earthflows only starts in the 1940s and continues to 2004. Therefore it can be speculated that for the period covered in this thesis the catchments have evolved to the stage of 'Interrupted Relaxation' in the post-deforestation evolution characterised by Crozier amd Preston (1999) or the $3^{\text {rd }}$ phase as proposed by Brooks et al. (2002). Over this time the colluvial footslopes have become a significant source of the earthflows, and thus failures are occurring on both lower and upper parts of the slopes. Because of this a tentative time scale can now be introduced to the Terrain Event-Resistance Model developed by Crozier and Preston (1999) (Figure 6.7). 


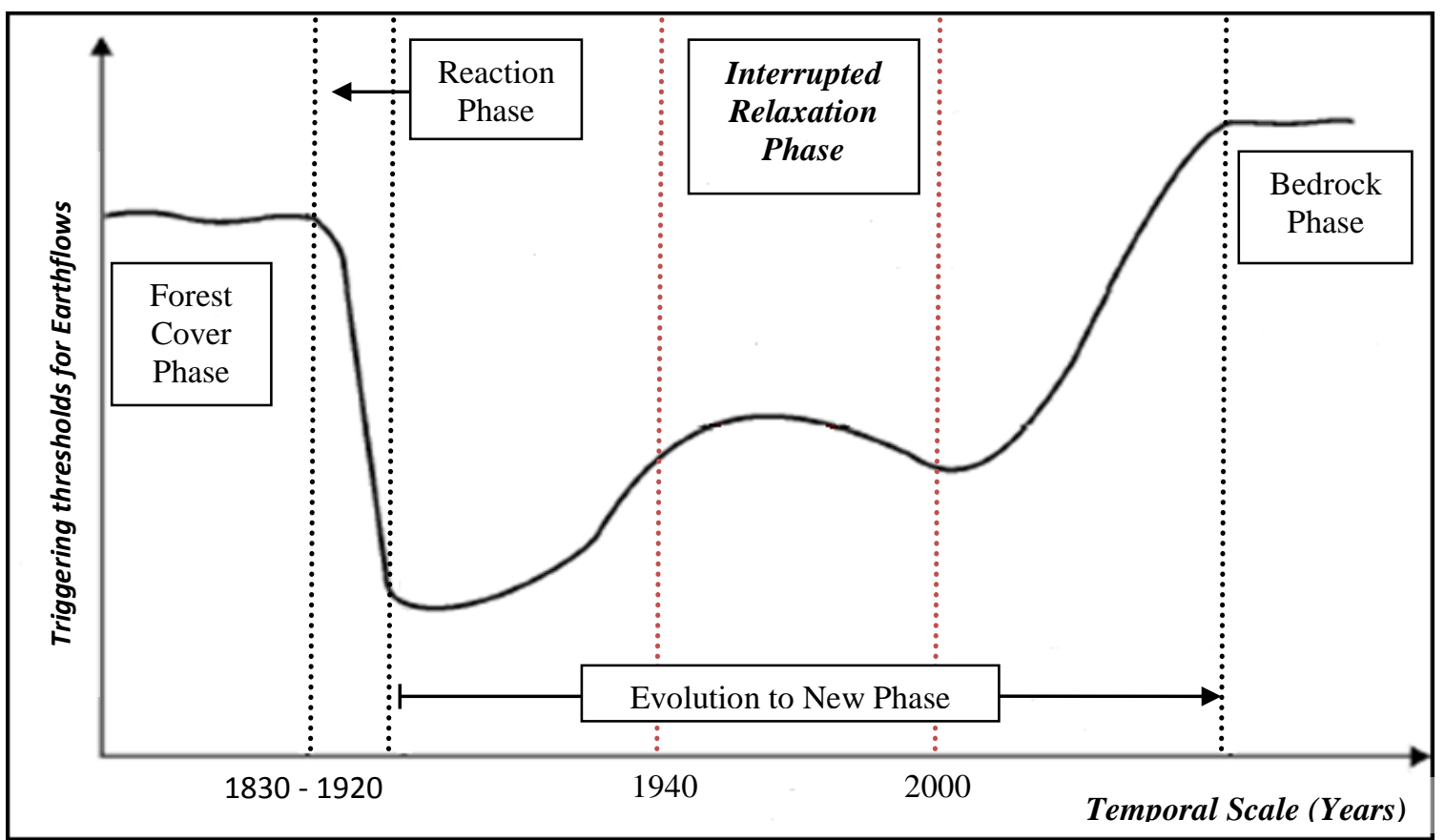

Figure 6.7 Evolutionary model of terrain resistance following deforestation. Under the Forested Phase triggering thresholds were high because of the protective effect of vegetation. After forest removal and conversion to pasture by European settlers between 1830 and 1920 A.D. the systems moves into the Reaction Phase where the threshold for earthflows is reduced dramatically resulting in widespread erosion. After this the Evolution to a New Phase begins where the sensitivity to failure slowly decreases (i.e. the triggering threshold increases) and eventually the system moves towards a new Bedrock Phase. (Adapted from Crozier and Preston, 1999; Brooks et al., 2002).

During the Forest Phase the earthflows are located at the base of the slopes due to a build up of pore water pressure. Due to this close proximity to the channel the off-slope sediment delivery ratios for these earthflows are high. The removal of indigenous forest from the slopes results in a higher density of earthflows in the reaction to this systemic perturbation. After this, earthflows regress progressively upslope as available regolith is removed from the lower slopes in previous events. A consequence of this upslope retreat is a corresponding decrease in sediment delivery. Eventually the system moves towards a new Bedrock Phase, where sheet and gully erosion are predominant as continued regolith exhaustion has resulted in a soil mantle below the critical depth for 
mass movement failure. This thesis focuses on a sub-phase during this evolution termed the Interrupted Relaxation Phase where the ripening of the lower colluvial slopes (which is a consequence of undelivered material from earlier failure generating events) results in an apparent random pattern to scar location. Thus no strong spatial pattern to sediment delivery is observed in this phase.

\subsection{Time Independent Sediment Delivery Ratios}

The objective of Aim Three was to identify the temporal pattern in catchment sediment delivery. It was hypothesised that sediment delivery ratios will decrease with time since the initial disturbance event of the indigenous forest removal. Yet across the five catchments, no temporal pattern to sediment delivery ratios were observed. Accordingly, for the time period observed in this thesis it can be considered that there is effectively a random pattern to earthflow location. The reasons for this have been given above.

Therefore, the focus for predicting sediment delivery needs to be on modelling the behaviour of storage units in the catchment as a whole, rather than on local scale changes in slope-channel connectivity. This can be undertaken on a sub-catchment scale using catchment area in landslide prone areas. Reflecting well-understood controls on sediment delivery, the hypothesised spatial pattern to sediment delivery ratio was a decrease as catchment size increased. This trend is seen with strong correlation values through the five catchments, and in particular the Mangakiore Catchment B. Smaller headwater catchments are expected to have higher drainage density and straight steep slopes resulting in high connectivity, whereas large scale catchments have more potential for fluvial storage in floodplains and overbank deposits which creates a buffer to both off-slope delivery and within channel transportation. Consequently, sediment delivery ratios are expected to be lower where the drainage density is lower. Yet the drainage density in these field sites does not vary greatly throughout the catchment due to their relatively small size and buffers to off-slope delivery are not present. For this 
reason, high connectivity is prevalent throughout all the catchments with the straight slopes leading directly into channels.

From these findings two different approaches can be taken to apply the sediment delivery ratios derived in this thesis to large scale modelling programmes (i.e. the Terrestrial Landscape Change: MARGINS Source-to-Sink New Zealand Programme). The first is to determine a catchment sediment delivery ratio based on catchment size (Figure 6.8). This can then be applied to the volume of sediment generated by earthflows, either modelled or observed within a catchment of given size, to determine the total volume of sediment delivered to the fluvial network in the event which generated them.

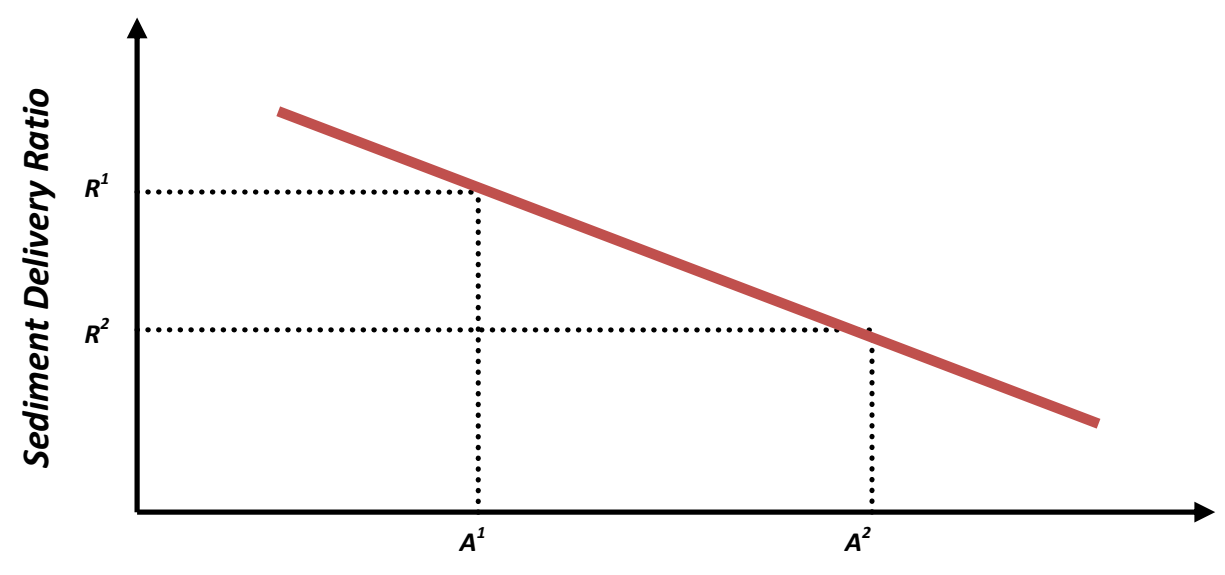

Area of the Catchment

Figure 6.8 Sediment Delivery Ratio determined from catchment size.

These spatial sediment delivery curves are given below for each land system (Figures 6.9-6.11). The large amount of scatter for these trend lines displays how variable sediment delivery ratios are on a temporal scale. Therefore, a more accurate linear regression could be taken from an individual catchment for a single time series as given in Chapter Five. 


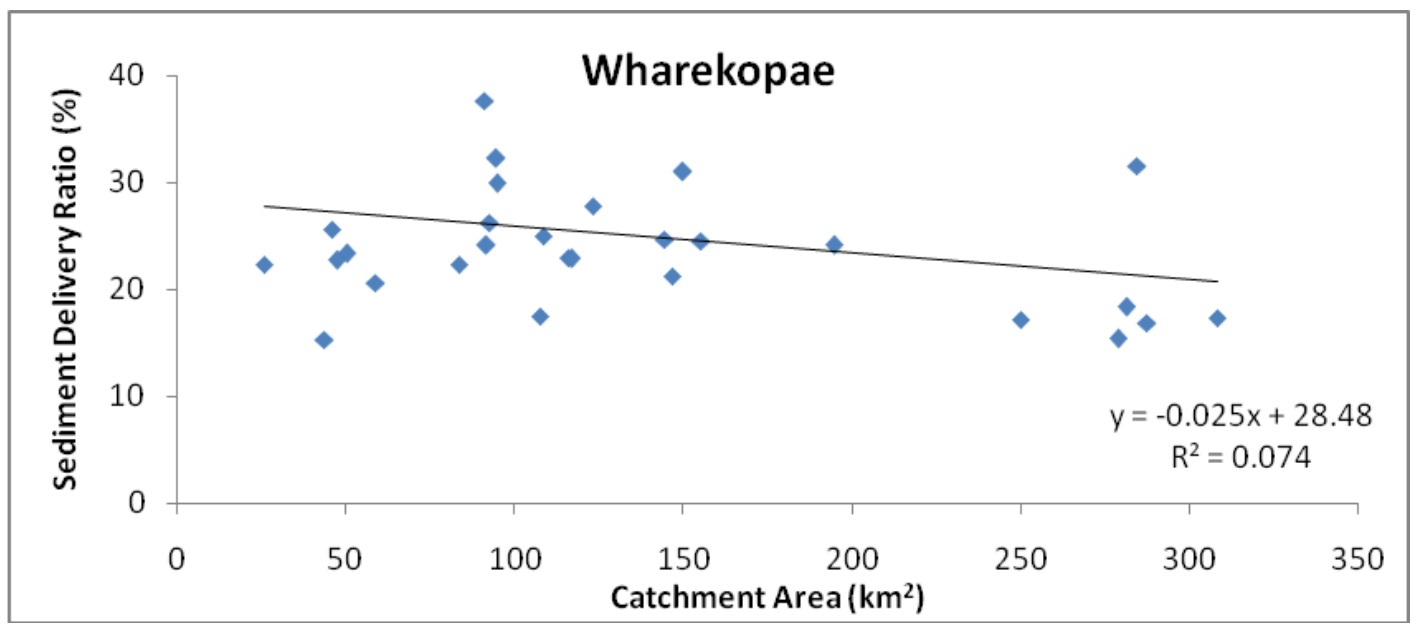

Figure 6.9 Sediment delivery ratios for the Wharekopae land system.

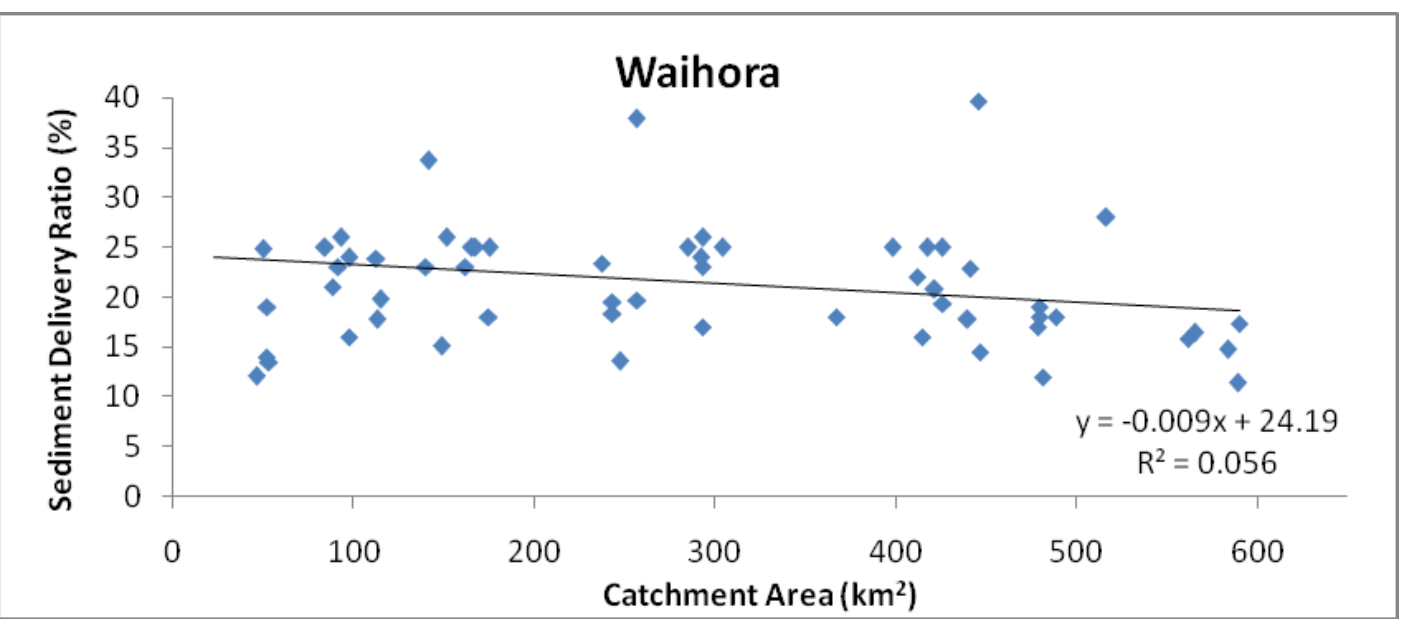

Figure 6.10 Sediment delivery ratios for the Waihora land system.

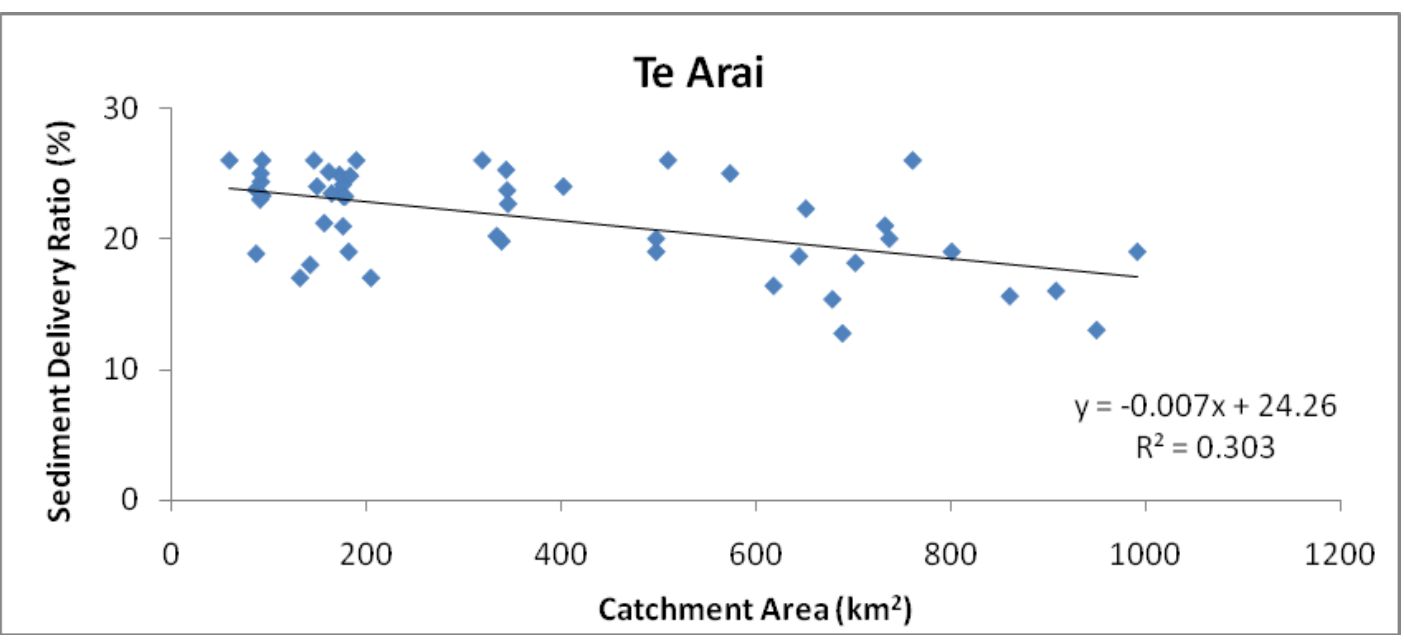

Figure 6.11 Sediment delivery ratios for the Te Arai land system. 
The second approach is to derive connectivity for the catchment and from this apply a sediment delivery ratio to the connected scars. If the distance of scars from the channel for all aerial photography is grouped for each catchment (or land system) a timeindependent measure of connectivity can be derived, and from this an estimate of catchment sediment delivery. The curves for each of the catchments have been combined, and in Figure 6.12 the average total length of earthflows (combined scar length and runout length) for each catchment has been applied to these curves to obtain a measure of connectivity.

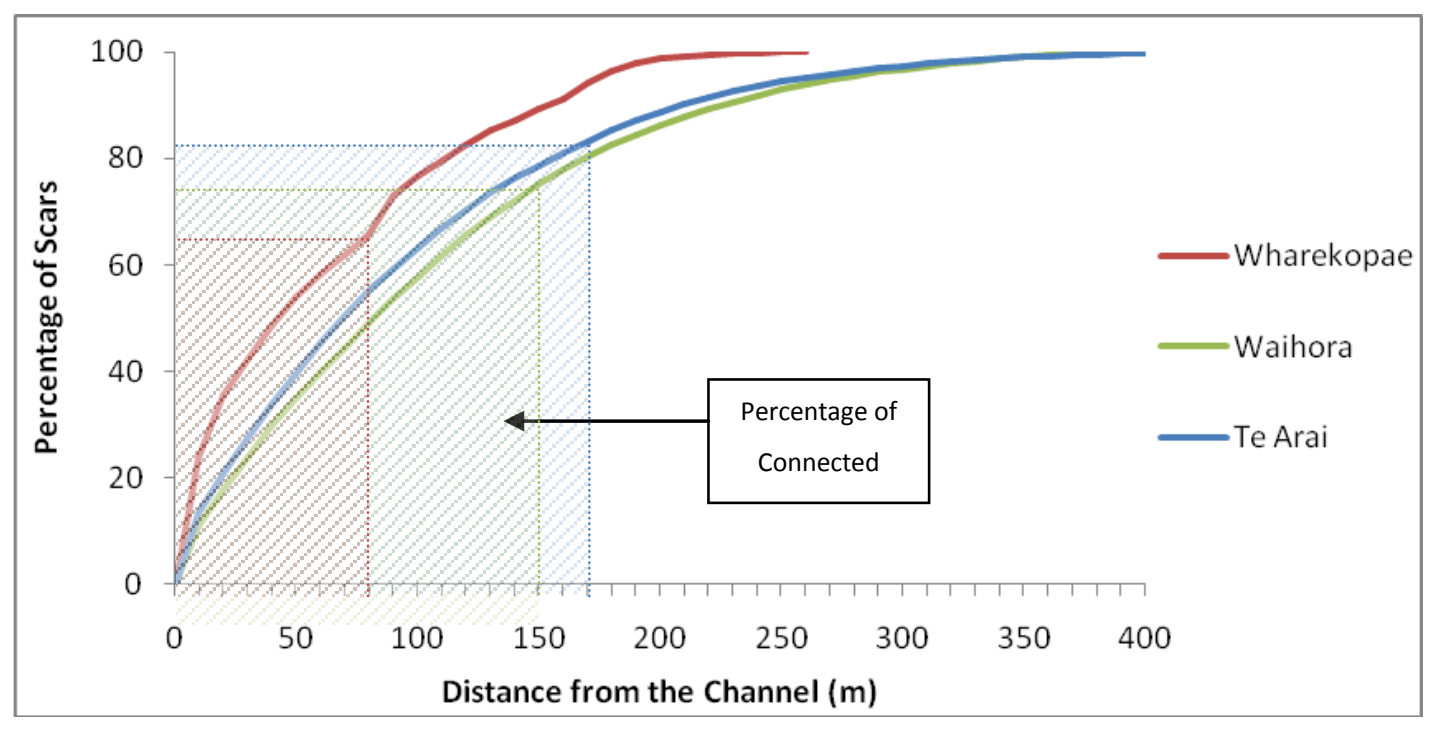

Figure 6.12 Cumulative percentage of the earthflow scars in relation to distance from the fluvial network for the five field sites representing the Wharekope (Waimoa catchment), Waihora (Ahioteatua catchments) and Te Arai (Mangakiore catchments) land systems. The average runout distance (ratios of scar length to runout length of 3:1) of these catchments is combined with the average scar length to determine the percentage of scars which are likely to intersect the channel. For these percentages a sediment delivery ratio can be applied to determine the overall catchment sediment delivery ratio using the total volumes of sediment generated for each land system. 
This measure of connectivity is determined as the percentage of scars connected to the channel in each catchment. For example, in the Mangakiore catchments the average earthflow length is $170 \mathrm{~m}$ and $82 \%$ of failures are within this distance of the channel (Figure 6.12). From this, the Te Arai land system displays extremely high hillslope coupling with the fluvial network, the Waihora land system moderate coupling and the Wharekopae moderate to low coupling with the fluvial network. If the total volume of sediment generated within each catchment for a storm event is determined, for instance through using relationships between storm magnitude and sediment generation (i.e. Reid and Page, 2002), this observation can be used, in conjunction with a representative sediment delivery ratio (i.e. Preston, 2008 or Page et al, 1999) to estimate a catchment sediment delivery ratio.

\subsubsection{Validation of the Sediment Delivery Ratios}

At Hinenui, sediment is infilling the ephemeral channels (Figure 6.13) which suggests efficient off-slope delivery and inefficient within-channel transport. In the other catchments the significantly higher runoff value, due to their larger size, results in more efficient channel transport. Therefore a higher volume of sediment once entrained into the fluvial network will be transported to the outlet of the study catchment. Because of this a clarification needs to be given if the results in this thesis are to be applied elsewhere. The $27 \%$ ratio for Hinenui and all the catchment sediment delivery ratios derived in this thesis are for off-slope sediment delivery to the channel network. They do not incorporate the ratio of sediment, once entrained into the fluvial network, which makes it to the catchment outlet. 


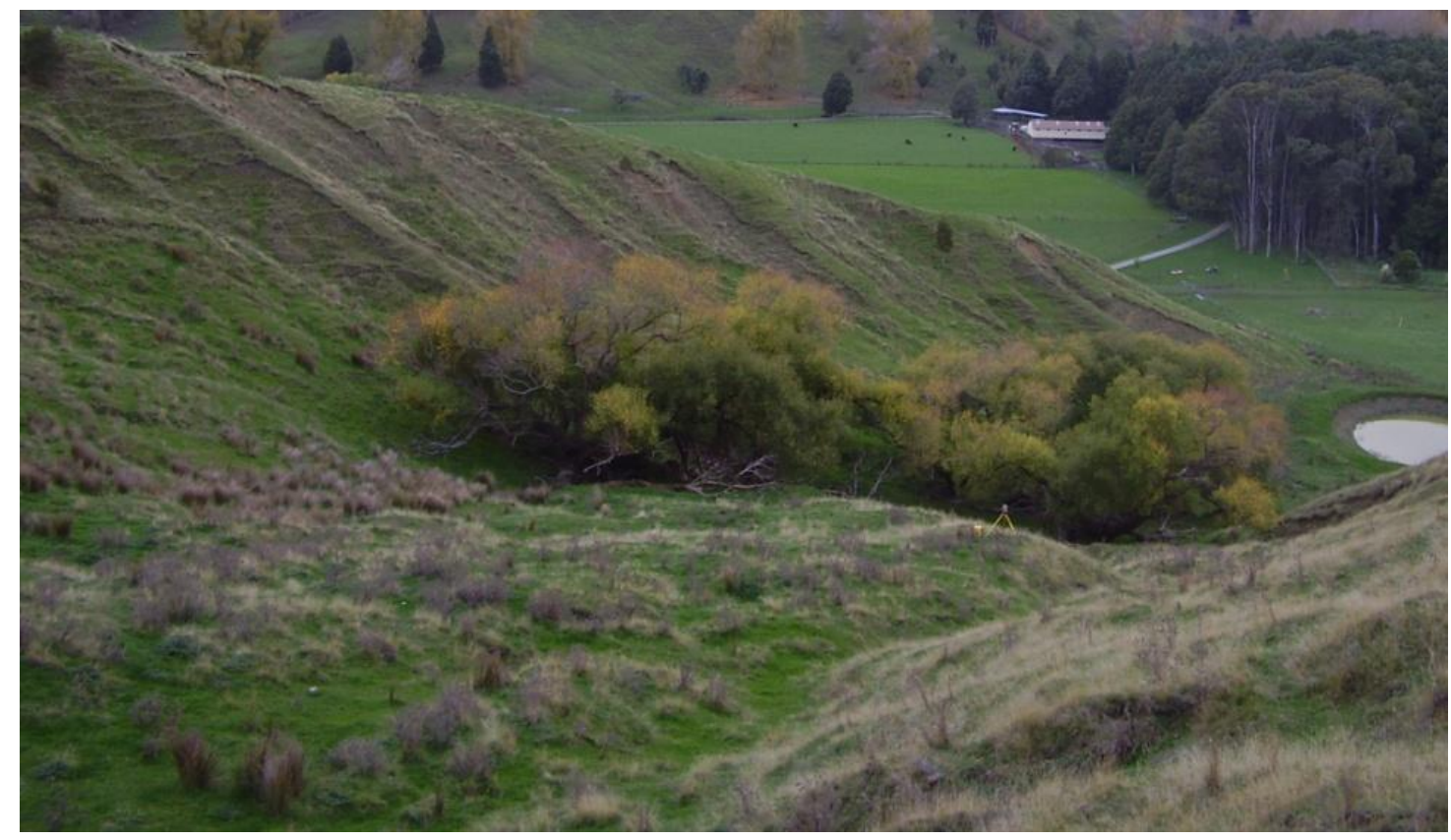

Figure 6.13 Sediment slug infilling the Hinenui valley. This is due to the high volume of sediment being delivered off-slope and low percentages of this sediment being entrained in the ephemeral channels and transported further down the catchment. (Photos: K. Jones, 2008).

Nevertheless, the sediment delivery ratios derived here for the five catchments within the Waipaoa catchment could be either underestimates or overestimates when using the inenui ratio of $27 \%$ for individually connected scars. For this research $27 \%$ is considered neither right nor wrong for the sediment delivery ratio for connected failures but rather the most appropriate value as it was based on empirical observations immediately following a high magnitude storm event $(\sim 250 \mathrm{~mm})$. The Hinenui catchment, located on the rolling coastal hills, is quite different to the other study catchments used in this thesis. It has shorter and less steep slopes where the footslopes abut the alluvial terraces compared to the Waihora and Te Arai sub-catchments where the longer steep slopes drain directly into the stream channels. So while the Hinenui slopes are shorter, suggesting higher ratios of hillslope channel coupling, they also abut alluvial terraces which can act as a buffer to sediment delivery. However there is evidence to suggest that $27 \%$ could be an underestimate if applied to the other catchments since off-slope delivery is potentially more efficient at these sites. Steeper 
slopes suggest longer runout distances and larger elevation difference between the scar and the channel which was identified as an overriding factor on runout distances at Hinenui. Therefore, catchment sediment delivery ratios were also determined assuming a 50\% delivery ratio for individual connected scar and this data is given in Appendix C.

\subsection{Conclusion}

The results derived in this thesis have shown that sediment delivery is a complex process. It cannot be adequately modelled using regression analysis of morphometric properties. While it varies in both space and time, there are no predictable trends on a temporal scale. The results derived in this thesis suggest that regolith exhaustion since deforestation, and the associated increase in the rainfall thresholds for failure, is also not a straight forward process. While the concept of a temporal pattern to sediment delivery ratios is not rejected, it is considered too difficult to accurately model on the time scale defined in this thesis. Instead, it is suggested that the temporal patterns of sediment delivery derived in this thesis relate to the Interrupted Relaxation Phase of Crozier and Preston's (1999) trajectory of catchment evolution following a large scale perturbation.

Because of this there is no temporal aspect that needs to be taken into account when applying the derived sediment delivery ratios to model sediment routing through a large scale catchment on a contemporary time scale. The spatial scale to catchment sediment delivery can be taken from the negative linear trend observed as catchment size increases. However, there is large scatter in this relationship due to the random location of scars between photos. As an alternative, average scar connectivity can also be applied to the three land systems to determine the overall contribution earthflows make to the sediment yield in a large magnitude storm event.

The following chapter gives an overview to this thesis and summarises all the results derived for understanding patterns in off-slope sediment delivery. It also provides recommendations for future research of sediment delivery in the Waipaoa catchment. 


\subsection{Introduction}

The Waipaoa Catchment is a dynamic and evolving large scale basin. The naturally high sediment yield provides a catchment which is ideal to demonstrate the entire source to sink sediment progression (Hicks et al., 1996). Yet the widespread conversion from the indigenous podocarp-broadleaf forest to pasture faming by European settlers in the late $19^{\text {th }}$ and early $20^{\text {th }}$ Centuries has resulted in a profound and long term change to sediment pattern in the catchment (Kettner et al., 2007). The catchment has undergone significant changes in the thresholds for initiation of erosional processes (Hicks et al., 2000) and the importance of gullying and shallow landsliding has increased as the removal of the forest cover has reduced the stability of these soft Tertiary hillslopes (Hicks, 1991).

While there is understanding of the changes in the above erosion processes, this does not necessarily transfer to a similar understanding of their contribution to the overall sediment yield on the contemporary time scale. The amount of sediment transferred from the hillslopes to the channels is not constant over time. Hillslope channel coupling at varying spatial and temporal scales needs to be quantified to understand its influences on the long term catchment sediment yield. The goal of this thesis was to display the spatial and temporal patterns of sediment delivery ratios for earthflows in the Waipaoa Catchment. Specifically, the aim was to explore the trends in delivery as they relate to the evolutionary stage of the catchment represented by the time since the initial disturbance event of land use change.

\subsection{Deriving Off-Slope Delivery Ratios}

An empirical approach was undertaken to both model sediment delivery ratios for the three research aims developed for this thesis. 
Aim One was to:

Develop a multiple regression equation to predict the connectivity of individual failures (and thus enabling summation to derive an overall sediment delivery ratio for a small sub-catchment) based on simple predictive variables.

Multiple regression analysis was undertaken to model the off-slope sediment delivery as a function of a range of morphometric variables, based on a dataset describing 71 earthflows at Hinenui in a 2002 storm event. Unfortunately, the analysis of morphometric variables of the earthflows and their runout paths failed to explain the variability in off-slope delivery. This suggests that the internal properties of the debris flow, which were not modelled in this research, may have an overriding influence for the delivery of sediment to the ephemeral and permanent stream channels.

Therefore, new techniques to predict sediment delivery from earthflow scars observed in sequential aerial photos were determined. A standard sediment delivery ratio of $27 \%$ (Preston, 2008) estimated from empirical observations at the Hinenui field site in 2002 was applied to the connected scars at the other five field site catchments featured in this thesis. From this, the total volume of delivered sediment to the fluvial network was compared to the total volume of sediment generated by the scars observed in the aerial photo to develop the catchment sediment delivery ratios for each aerial photo covering each catchment.

\subsection{Application of Predictable Patterns in Catchment Sediment Delivery Ratios}

The following two aims were developed to determine the spatial and temporal patterns in sediment delivery. This allows for the incorporation of these patterns into numerical modelling of catchment evolution including sediment sources, stores, and transport routes. 
Aim Two was developed to:

Determine the connectivity and sediment delivery ratios of shallow rainfall triggered landslides for a range of catchment sizes within three landslide prone land systems in the Waipaoa catchment to identify patterns in hillslope channel coupling directly related to catchment size and channel density.

And Aim Three was developed to:

Define the connectivity and sediment delivery ratios of shallow rainfall triggered landslides for a range of temporal scales within the Waipaoa catchment to identify patterns in sediment delivery ratios related to catchment evolution following change in boundary conditions.

While the results supported the expected linear decrease in the sediment delivery ratios as catchment size increases, the hypothesis that sediment delivery ratios also had a temporal pattern was not supported. Consistent upslope progression of the scars in relation to the channel in subsequent storm events was not detected in any of the five catchments. The changes to triggering thresholds, regolith exhaustion, and associated catchment development towards a more stable phase are not straight forward. Therefore the temporal evolution of sediment delivery ratios cannot be expected to be clear. Changes in the hydrological and geotechnical properties of the hillslopes means there is no predictable pattern to failure location over time. This is because the catchments appear to be in the middle of the Crozier and Preston's (1999) Interrupted Relaxation Phase or Brooks et al., (2002) $3^{\text {rd }}$ Phase. As a result, the potential for hillslope channel coupling varies between storm events as failures occur on both the upper slope and the colluvial lower slope.

Because of this, sediment delivery needs to be viewed only at a spatial scale when being incorporated into numerical modelling. There is a predictable decrease in catchment sediment delivery ratios as catchment size increases. The percentage of connected earthflows decreases as catchment size increases due to reductions in the channel density and an increase in frequency of barriers preventing off-slope delivery. 


\subsection{Recommendations for Future Research}

A number of future studies could be undertaken to further the understanding of sediment delivery ratios for earthflows. Numerical modelling of the internal properties of the failure could allow for more accurate prediction of off-slope delivery ratios for individual failures. Yet collecting this data at the desired spatial resolution is not a straight forward process (Hennrich and Crozier, 2004). Nevertheless, changing hydrological and geotechnical properties of the slopes related to catchment evolution, as modelled by Brooks et al., (2002), could be incorporated to improve modelling. Thus, the predicted sediment delivery ratios would integrate the temporal stage of catchment evolution regardless of whether the failure is in undisturbed or redeposited regolith. If an accurate predictive model for sediment delivery from individual failures was developed this could be re-applied to the research undertaken in this thesis to more accurately identify the spatial and temporal patterns of sediment delivery in the Waipaoa Catchment.

Modelling the sediment routing once entrained into the fluvial network was beyond the scope of this thesis. Consequently, further research is vital to understand the sediment delivery ratio from failure on the slope and the transport of this sediment throughout the fluvial network. It would be useful to develop a ratio which determines the percentage of sediment generated on the inland hillslopes that is instantly delivered at the outlet of the catchment during a storm event compared to the percentage delivered after temporary storage within the system. From this, the importance of secondary erosional processes and the frequency of their triggering events could also be quantified. This would highlight the importance of the initial failure process and the role of extreme events in the sediment cores taken from the Poverty Bay shelf and slope. 


\section{References}

Adams, J., 1981. Earthquake-dammed lakes in New Zealand, Geology, 9: 215-219. Allsop, F., 1973. The story of Mangatu: the Forest which Healed the Land, New Zealand Forest Service Information Series 62, Government Printer, Wellington, New Zealand.

Berryman, K., Marden, M., Eden, D., Mazengarb, C., Ota, Y. and Moriya, I., 2000. Tectonic and paleoclimatic significance of Quaternary river terraces of the Waipaoa River, East Coast, North Island, New Zealand, New Zealand Journal of Geology and Geophysics, 43: 229-245.

Beven, K. and Kirkby, M.J., 1979. A physically-based variable contributing area model of basin hydrology, Hydrological Sciences Bulletin, 24: 43-69.

Brooks, S.M., Crozier, M.J., Preston, N.J. and Anderson, M.G., 2002. Regolith stripping and the control of shallow translational hillslope failure: application of a twodimensional coupled soil hydrology-slope stability model, Hawke's Bay, New Zealand, Geomorphology, 45: 165-179.

Burns, R. G., 1979. An improved sediment delivery model for Piedmont forests, In: Environmental Resource Centre Annual Report, Georgia Institute of Technology, Atlanta, U.S.A., 379-382.

Casadei, M., Dietrich, W.E. and Miller, N.L., 2003. Testing a model for predicting the timing and location of shallow landslide initiation in soil-mantled landscapes, Earth Surface Processes and Landforms, 28: 925-950.

Chorley, R. J. and Kennedy, B. A., 1971. Physical geography, a systems approach. London, Prentice-Hall International.

Corominas, J., Baeza, C. and Saluena, I., 1991. The influence of geometrical slope characteristics and landuse on the development of shallow landslides, In: Bell (ed.), 1991, Landslides, Balkema, Rotterdam, 919-924.

Crozier, M.J., Eyles, R., Marx, S., McConchie, J., and Owen, R., 1980. Distribution of landslips in the Wairarapa hill country, New Zealand Journal of Geology and Geophysics, 21: 575-586.

Crozier, M. J. 1986. Landslides: causes, consequences and environment, London, Croom Helm

Crozier, M. J., 1996. Runout behaviour of shallow, rapid earthflows, Zeitschrift fur geomorphology, 105: 35-48.

Crozier, M.J., 1997. The climate-landslide couple: a Southern Hemisphere perspective, In: Matthews, J.A., Brunsden, D., Frenzel, B., Gläser, B. and Weiß, M. (eds), Rapid mass movement as a source of climatic evidence for the Holocene, Gustav Fischer Verlag, Stuttgart, 333-354.

Crozier, M.J., 1999. Prediction of rainfall-triggered landslides: A test of the antecedent water status model, Earth Surface Processes and Landforms, 24: 825-833. 
Crozier, M. J. and Preston, N. J., 1999. Modelling changes in terrain resistance as a component of landform evolution in unstable hill country, Process Modelling and Landform Evolution, 78: 267-284.

Crozier, M.J., 2005. Multiple-occurrence regional landslide events in New Zealand: Hazard management issues, Landslides, 2: 247-256.

DeRose, R.C., Trustrum, N.A., and Blaschke, P.M., 1993. Post-deforestation soil loss from steepland hillslopes in Taranaki, New Zealand, Earth Surface Processes and Landforms, 18: 131-144.

De Rose, R.C., 1996. Relationship between slope morphology, regolith depth, and the incidence of shallow landslides in eastern Taranaki hill country, Zeitschrift fur Geomorphologie Supplementband, 105: 49- 60.

DeRose, R.C., Gomez, B., Marden, M. and Trustrum, N.A., 1998. Gully erosion in Mangatu Forest, New Zealand, estimated from digital elevation models, Earth Surface Processes and Landforms, 23: 1045-1053.

De Roo, A.P.J., 1998. Modelling runoff and sediment transport in catchments using GIS, Hydrological processes, 12: 905-922.

de Vente, J., Poesen, J., Arabkhedri, M., and Verstraeten, G., 2007. The sediment delivery problem revisited, Process in Physical Geography, 31: 155-178.

Dickinson, W.T. and Wall, G.J. 1977: The relationship between source-area erosion and sediment yield, Hydrology Science Bulletin, 22: 527-530.

Dietrich, W.E., Dunne, T., Humphrey, N.F., and Reid, L.M., 1982. Construction of sediment budgets for drainage basins, In Sediment Budgets and Routing in Forested Drainage Basins, General Technical Report, 141: 5-23.

Dikau, R., Brunsden, D., Schrott, L. and Isben, M-L., 1996. Landslide recognition: identification, movement and causes. Great Briton, John Wiley and Sons Ltd.

Dymond, J. R., Jessen, M.R. and Lovell, L.R., 1999. Computer simulation of shallow landsliding in New Zealand hill country, Journal of Applied Earth Observation and Geoinformation, 1: 122-131.

Eden, D.N and Page, M.J., 1998. Palaeoclimatic implications of a storm erosion record from late Holocene lake sediments, North Island, New Zealand, Palaeogeography, Palaeoclimatology and Palaeoecology, 139: 37-58.

Eyles, G.O. 1983. Soil erosion in New Zealand, New Zealand Geographer, 39: 12-28.

Fryirs, K.A., Brierley, G.J., Preston, N.J. and Kasai, M., 2007. Buffers, barriers and blankets: the (dis) connectivity of catchment-scale sediment cascades, Catena, 70: 49-67.

Gage, M. and Black, R.D., 1979. Slope - stability and geological investigations at mangatu state forest, New Forest Service, Forest Research Institute Technical Paper no. 66. 
Glade, T., Crozier, M.J. and Smith P., 2000. Applying probability determination to refine landslide-triggering rainfall thresholds using an empirical Antecedent Daily Rainfall Model, Pure and Applied Geophysics, 157: 1059-1079.

Glymp, L.H., 1954. Studies of sediment yields from watersheds, International Association Hydrology, IUGC, 10 ${ }^{\text {th }}$ General Assembly, Roma, 1: 178-191.

Gomez, B., Banbury., K., Marden., M., Trustrum, N., Peacock., D.H. and Hoskin., P.J., 2003. Gully erosion and sediment production: Te Weraroa Stream, New Zealand, Water Resources Research, 37: 1813-1823.

Hancox, G.T. and Wright, K., 2005. Analysis of landsliding caused by the 15-17 February 2004 rainstorm in the Wanganui-Manawatu hill country, southern North Island, New Zealand. Institute of Geological and Nuclear Sciences science report 2005/11, 64p.

Henderson, J. and Ongley, M. 1920. The geology of the Gisborne and Whatatutu Subdivisions, Raukumara Divison, New Zealand Department of Mines, Geological Survey Bulletin, 21.

Hennrich, K. and Crozier, M. J., 2004. A hillslope hydrology approach for catchmentscalel slope stability analysis, Earth Surfac, Process and Landforms, 29: 599610

Hessell, J.W.D., 1980. The climate and weather of the Gisborne region, New Zealand Meterological Service, Miscellaneous Publication, 115, 8.

Hicks, D.L., 1991. Erosion under pasture, pine plantations, scrub and indigenous forest, NewZealand Forestry, 26: 21-22.

Hicks, D.M., Hill, J. and Shankar, U., 1996. Variation of suspended sediment yields around New Zealand: the relative importance of rainfall and geology. In Walling, D.E. and Webb, B.W. (Eds), Erosion and sediment yield: global and regional perspectives, IAHS Publication no. 263: 149-156.

Hicks, D.M., Gomez, B. and Trustrum, N.A., 2000. Erosion thresholds and suspended sediment yields: Waipaoa River Basin, New Zealand, Water Resources Research, 36: 1129-1142.

Hicks, D.M. and Gomez, B., 2003. Tools in fluvial geomorphology. Chichester, Wiley.

Hicks, D.M., Gomez, B. and Trustrum, N.A., 2004. Event suspended sediment characteristics and the generation of hyperpycnal plumes at river mouths: East Coast Continental Margin, North Island, New Zealand, Journal of Geology, 112: 471-485.

Hong, Y., Adler, R.F. and Huffman, G.J., 2006. Evaluation of the potential of NASA multi-satellite precipitation analysis in global landslide hazard assessment, Geophysical Research Letters, 33.

Hovius, N., Stark, C.P. and Allen, P.A.,1997. Sediment flux from a mountain belt derived by landslide mapping. Geology, 25: 231-234. 
Iverson, R.M., 2000. Landslide triggering by rain infiltration, Water Resources Research, 36: 1897-1910.

Iverson, R.M., Reid, M.E., Iverson, N.R., LaHusen, R.G., Logan, M., Mann, J.E. and Brien, D.L., 2000. Acute Sensitivity of Landslide Raters to Initial Soil Porosity, Science, 290: 513-516.

Jones, K. L., 1988. Horticulture and settlement chronology of the Waipaoa River catchment, East Coast, North Island, New Zealand, New Zealand Journal of Archaeology, 10: 19-51.

Keefer DK., 1984. Landslides caused by earthquakes, Geological Society of America Bulletin, 95: 406-421.

Kettner, A.J., Gomez, B. and Syvitski, J.P.M., 2007. Modeling suspended sediment discharge from the Waipaoa River system, New Zealand: the last 3000 years, Water Resources Research, 43.

Kettner, A.J. and Syvistki. J.P.M., 2004. Predicting discharge and sediment of the Pô river, Italy since the late glacial maximum. Technical Report CO 80309-0450, University of Colorado.

Koi, T., Hotta, N., Ishigaki, I., Matuzaki, N., Uchiyama, Y. and Suzuki, M., 2008. Prolonged impact of earthquake-induced landslides on sediment yield in a mountain watershed: The Tanzawa region, Japan, Geomorphology, 101: 692702.

Krausse, M.; Eastwood, C.; and Alexander, R. R. 2001: Muddied waters: Estimating the National Economic cost of soil erosion and sedimentation in New Zealand, Landcare Research New Zealand Ltd, Lincon. 47pp.

Laflen, J.M., Elliot, W.J., Flanagan, D.C., Meyer, C.R. and Nearing, M.A., 1997. WEPP - Predicting water erosoion using a process - based model, Journal of Soil and Water Conservation, March-April, 96-102.

Lave, J. and Burbank, D., 2004. Denudation processes and rates in the Transverse Ranges, southern California: Erosional response of a transitional landscape to external and anthropogenic forcing, Journal of Geophysical Research, 109.

Lin, G-W., Chen, H., Hovius, N., Horng, M-J., Dadson, S., Meunier, P. and Lines, M., 2008. Effects of earthquake and cyclone sequencing on landsliding and fluvial sediment transfer in a mountain catchment, Earth Surface Processes and Landforms, 33: 1354-1373.

Litchfield, N., Ellis, S., Berryman, K. and Nicol, A., 2007. Insights into subduction related uplift along the Hikurangi Margin, New Zealand, using numerical modelling, Journal of Geophysics Research, 112.

Litchfield, N., Berryman, K., Brackley, H., Carter, L., Marden, M., Page, M., Trustrum, N. 2008. The Waipaoa Sedimentary System: research review and future directions. Sediment Dynamics in Changing Environments, Proceedings of a symposium held in Christchuch, New Zealand. IAHS Publication 325: 408-416. 
Lu, H.; Moran, C. J. and Prosser, I. P. 2006. Modelling sediment delivery ratio of the Murray Darling Basin, Environment Modelling and Software, 21: 1297-1308.

Lufafa, A.; Tenywa, M. M.; Isabirye, M.; Majaliwa, M. J. G. and Woomer, P. L. 2003. Prediction of soil erosion in a Lake Victoria basin catchment using a GIS-based universal soil loss model, Agricultural Systems, 76: 883-894.

MacKay, J.A., 1982. Historic Poverty Bay, Poverty Bay - East Coast Centennial Council, Gisborne, New Zealand.

McGlone, M.S., Howorth, R. and Pullar, W.A., 1984. Late Pleistocene stratigraphy, vegetation and climate of the Bay of Plenty and Gisborne regions, New Zealand, New Zealand Journal of Geology and Geophysics, 27: 327-350.

Malamud, B.D., Turcotte, D.L., Guzsetti, F. and Reichenbach, P., 2004. Landslides, earthquakes and erosion, Earth and Planetary Science Letters, 229: 45-59.

Manaaki Whenua - Landcare Research, last updated 2/6/2008. New Zealand Land Resource Inventory (NZLRI), accessed at www.landcareresearch.co.nz/databases/nzlri.asp, date accessed: 4/6/2008.

Maner, S.B., 1958. Factors influencing sediment delivery rates in the Red Hills physiographic area, Trans American Geophysics Union, 39: 669-675.

Marden, M. \& Rowan, D. 1994. Protective value of vegetation on tertiary terrain before and during Cyclone Bola, East Coast, North Island, New Zealand, New Zealand Journal of Forestry Science, 23: 2.

Marden, M., Arnold, G., Gomez, B. and Rowan, D., 2005. Pre- and post-reforestation gully development in Mangatu Forest, East Coast, North Island, New Zealand, River Resources Application, 21: 739-756.

Marden, M., Mazengarb, C., Palmer, A., Berryman, K. and Rowan, D., 2008. Last glacial aggradation and postglacial sediment production from the non-glacial Waipaoa and Waimata catchments, Hikurangi Margin, North Island, New Zealand, Geomorphology, 99: 404-419.

Marden, M., Betts, H., Arnold, G. And Hambling, R., 2008. Gully erosion and sediment load: Waipaoa, Waiapu and Uawa rivers, eastern North Island, New Zealand. Sediment Dynamics in Changing Environments, Proceedings of a symposium held in Christchurch, New Zealand. IAHS Publication 325: 339-350.

Mazengarb, C., Francis, D.A. and Moore, P.R., 1991. Sheet Y16 Tauwharepare, DSIR Geological Map of New Zealand, scale 1: 50000.

Mazengarb, C. and Speden, I. G. (Compilers), 2000, Geology of the Raukumara area, Institute Geological and Nuclear Science 1:250 000 Geological Map 6. Institute of Geological and Nuclear Sciences Limited Sciences Limited, Lower Hutt, New Zealand.

Meade, R.H., 1982. Sources, sinks and storage of river sediment in the Atlantic drainage of the United States, The Journal of Geology, 90: 235-252. 
Mildenhall, D.C.and Brown, L.J., 1987. An early Holocene occurrence of the mangrove Avicennia marina in Poverty Bay, North Island, New Zealand; its climatic and geological implications, New Zealand Journal of Botany, 25: 281-294.

Milliman, J.D. and Meade, R.H., 1983. World-wide deliver delivery of river sediment to the oceans, The Journal of Hydrology ,91: 1-21.

Miller, D.J., Luce, C. and Benda, L., 2003. Time, space, and episodicity of physical disturbance in streams, Forest Ecology and Management, 178: 121-140.

Montgomery, D.R., Schmidt, K.M., Greenberg, H.M. and Dietrich, H.M., 2000. Forest clearing and regional landsliding, Geology, 28: 311-314.

Morgan, R.P.C., Quinton, J.N., Smith, R.E., Govers, G., Poesen, J.W.A., Auerswald, K., Chisci, G., Torri, D., and Styczen, M.E., 1998. The European soil erosion model (EUROSEM): a process-based approach for predicting sediment transport from fields and small catchments. Earth Surface Processes and Landforms, 23: 527544.

Mou, J. and Meng, Q., 1980. Sediment delivery ratio as used in the computation of watershed sediment yield, Hydrological. Engineering. Chinese Society of Hydrological Engineering, Beijing, China.

Mutchler, C.K. and Bowie, A.J., 1976. Effect of land use on sediment delivery ratios, In:Proceedings of the Third Federal Inter_Agency Sedimentation Conference, U.S. Water Resources Council, Washington, D.C., 1:11-12.

O'Loughlin, E.M., 1986. Prediction of surface saturation in natural catchments by topographic analysis, Water Resources Research, 22: 794-8-4.

O'Loughlin, C. and Ziemer, R.R., 1982. The importance of root strength and deterioration rates upon edaphic stability, in steepland forests, In: Waring R.H. (ed), Carbon uptake and allocation in subalpine ecosystems as a key to management, Oregon State University, Corvallis, Oregon, 70-78.

Omura, H. and Hicks, D. L. 1992. Probability of landslides in hill country. In: Bell, D. (Ed.), Landslides, Proceedings of the Sixth International Symposium, Christchurch, February 1992, vol. 2. A.A. Balkema, Rotterdam, 1045- 1049.

Ouyang, D. and Bartholic, J. 2001. Web-based GIS application for soil erosion prediction, Proceedings of An International Symposium - Soil Erosion Research for the 21st Century, Honolulu, Hawaii, 3-5.

Owen, R.C., 1981. Soil strength and microclimate in the distribution of shallow landslides, Journal of Hydrology, New Zealand, 20: 17-26.

Pain, C.F. and Hoskin, P.L., 1970. The movement of sediment in a channel in relation to magnitude and frequency concepts - a New Zealand example, Journal of Earth Sciences, 4: 17-23.

Page, M. J., Trustrum, N. A. and Dymond, J. R. 1994. Sediment budget to access geomorphic effect of a cyclone storm, New Zealand, Geomorphology, 9: 169188. 
Page, M. J. And Trustrum, N. A. 1997. A late Holocene lake sediment record of the erosion response to land use change in a steepland catchment, New Zealand, Zeitschrift fur Geomorphologie, 41: 369-392.

Page, M. J.; Reid, L. M. and Lynn, I. H. 1999: Sediment production from Cyclone Bola landslides, Waipaoa catchment, Journal of Hydrology (NZ), 38: 289-308.

Page, M. J., Trustrum, N. A. and Gomez, B., 2000. Implications of a century of anthropogenic erosion for future land use in the Gisborne-East Coast region of New Zealand, New Zealand Geographer, 56: 13-24.

Page, M. J., Harmsworth, G., Trustrum, N., Kasai, M. and Marutani, T., 2001. Waipaoa River, In Marutani, T., Brierley, G.J., Trustrum, N.A., Page, M.J. (Eds.), Sourceto-sink sedimentary cascades in Pacific Rim geo-systems, Matsumoto Sabo Work Office, Ministry of Land, Infrastructure and Transport of Japan, Matsumoto, 102-111.

Parsons, A.J., Brazier, R.E., Wainwright, J. and Powell, D.M. 2006. Scale relationships in hillslope runoff and erosion, Earth Surface Processes and Landforms 31: 1384-93.

Pearce, A.J. and Watson, A.J., 1986. Effects of earthquake-induced landslides on sediment budget and transport over a 50-yr period, Geology, 14: 52-55.

Pere, V.H., 2003. Formation and consequences of the Totangi Landslide Dam in the Ngatapa Valley, Gisborne, New Zealand, MSc Thesis, University of Canterbury, Christchurch, New Zealand.

Pillians, B., 1986. A late quaternary uplift map for the North Island, New Zealand, Royal Society of New Zealand Bulletin, 25: 409-417.

Preston, N.J., 2008. Off-slope sediment delivery from landsliding during a storm, Muriwai Hills, North Island, New Zealand. Sediment Dynamics in Changing Environments, Proceedings of a symposium held in Christchuch, New Zealand. IAHS Publication 325: 237-241.

Prosser, I.P., Rutherford, I.D., Olley, J.M., Young, W.J., Wallbrink, P.J. and Moran, C.J., 2001. Large-scale patterns of erosion and sediment transport in river networks, with examples from Australia, Marine and Freshwater Research, 52: 81-99.

Reid, L.M. and Page, M.J., 2002. Magnitude and frequency of landsliding in a large New Zealand catchment, Geomorphology, 49: 71-88.

Roehl, J.W., 1962. Sediment source areas, delivery ratios, and influencing morphological factors, International Association of Scientific Hydrology, 59: 202-213.

Roering, J.J., Schmidt, K.M., Stock, J.D., Dietrich, W.E. and Montgomery, D.R., 2003. Shallow landsliding, root reinforcement, and the spatial distribution of trees in the Oregon Coast Range, Canadian Geotechnical Journal, 40: 237-253. 
Rosser, B. J., 1997. Downstream fining in the Waipaoa river; an aggrading, gravel river bed river, East Coast, New Zealand, Unpublished MSc thesis, Massey University, Palmerston North.

Schmidt, K.M., Roering, J.J., Stock, J.D., Dietrich, W.E., Montgomery, D.R. and Schaub, T., 2001. The variability of root cohesion as an influence on shallow landslide susceptibility in the Oregon Coast Range, Canadian geotechnical Journal, 38: 995-1024..

Schneider, P., 2002. The Distribution of sediment resulting from a major landslide event, BSc(Hons), Research Project in Physical Geography, Victoria University of Wellington, New Zealand.

Schumm, S.A., 1977. The fluvial system, USA, Wiley.

Selby, M. J., 1993. Hillslope materials and Processes, 2nd edition, Great Briton, Oxford University Press.

Smale, M.C., McLeod, M. And Smale, P.N., 1997. Vegetation and soil recovery on shallow landslide scars in Tertiary hillcountry, East Cape region, New Zealand, New Zealand Journal of Ecology, 21: 31-41.

Smith, R. K., 1977. The morphology and hydrology of the Waipaoa basin, unpublished report, Ministry of Works and Development, Napier, 130p.

Thomas, V.J. and Trustrum, N.A.m 1984. A simulation model of soil slip erosion. In: Symposium on the Effects of Forest Land Use on Erosion and Slope Stability, Environment Policy Institute, East-West Centre University of Hawaii, Honolulu, pp. 83-89.

Trustrum, N. A., Thomas, V. J. and Lambert, M. G. 1984. Soil slip erosion as a constraint to hill country pasture production, Proceedings of the New Zealand Grasslands Association, 45: 57-64.

Trustrum, N.A. and DeRose, R.C., 1988. Soil depth-age relationship of landslides on deforested hillslopes, Taranaki, New Zealand, Geomorphology, 1: 143-160.

Trustrum, N. A., Gomez, B., Page, M. J., Reid, L. M. and Hicks, D. M., 1999. Sediment production, storage, output: the relative role of large magnitude events in steepland catchments, Zeitschrift fur Geomorphologie Suppl., 115: 71-86.

Vanoni, V. A. 1975: Sedimentation Engineering, Manual and Report No. 54, American Society of Civil Engineers, New York, N.Y.

Varnes, D. J., 1978: Slope movement types and processes. In Schuster, R. L. and Kirzek, R. J. (Eds.) Landslides - Analysis and Control. Transportation Research Board Special Report, National Academy of Sciences, 176: 11-33.

Wade, J.C. and Heady, E.O., 1978. Measurements of sediment control impacts on agriculture, Water Resources Research, 14: 1-8.

Walcott, R.I., 1987. Geodetci strain and the deformational history of the North Island of New Zealand during the late Cainozoic, Philosophical Transaction for the Royal Society of London, 321: 163-181. 
Walling, D. E., 1983. The sediment delivery problem, Journal of Hydrology, 65: 209237.

Walling, D. E. and Webb, B. W., 1996. Erosion and sediment yield: global and regional perspectives, IAHS Publication no. 263: 149-156.

Wasson, R.J., Mazari, R.K., Starr, B., and G. Clifton, 1998. The recent history of erosion and sedimentation on the Southern Tablelands of southeastern Australia: sediment flux dominated by channel incision, Geomorphology, 24: 219-398.

Williams, J.R. and Berndt, H.D., 1972. Sediment yield computed with Universal equation, Journal of Hydraulics Division, Proceedings of the American Society of Civil. Engineering, 98: 2087--2098.

Williams, J.R., 1977. Sediment delivery ratios determined with sediment and runoff models. International Association of Hydrology, Science Publication, 168--179.

Yitayew, M., Pokrzywka, S.J. and Renard, K. G., 1999: Using GIS for facilitating erosion estimation, Applied Engineering in Agriculture, 15: 295-301. 


\section{Appendix A: GIS Analysis}

- Flow Diagrams

- Visual Basic Scripts

- Python Scripts

\section{Appendix B: Multiple Regression Analysis}

- Raw data for Hinenui earthflows

- Liquid Limit Data

- Maps of the earthflows and Sediment Delivery

- Morphology of the catchment

- Regression equations

\section{Appendix C: Sediment Delivery Ratios}

- Sediment delivery ratios for the Waimoa, Ahoiteatua and Mangakaiore Catchments

- Trends in Sediment Delivery Ratios

\section{Appendix D: Earthflow Scars}

- Earthflow scars mapped inthe Waimoa, Ahioteatua and Managakiore Catchments

- Earthflow Aspect

- Earthflow Properties

\section{Appendix E: Storm History of the Waipaoa Catchment}




\section{Appendix A: GIS Analysis}


Digitally Delineating the Earthflow Scars

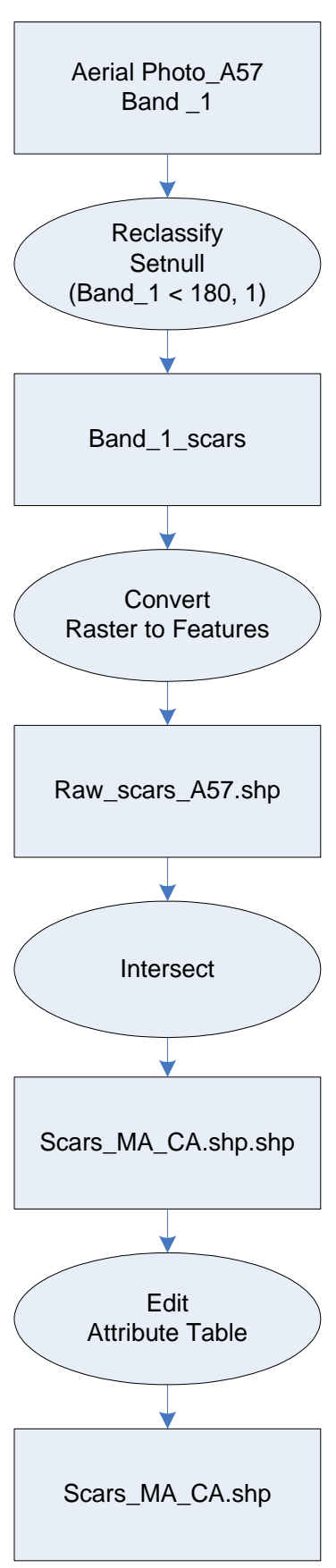

Digitally Delineating the Fluvial Network

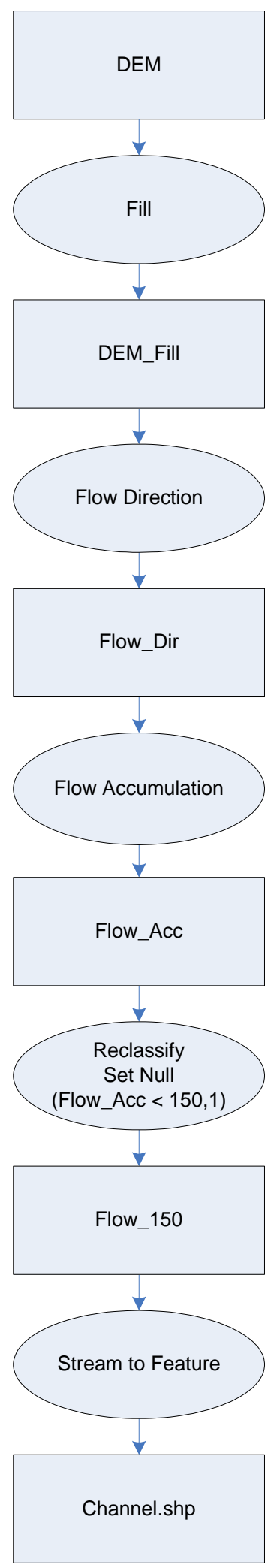


Visual Basic Script used to determine the 3D distance of the runout path:

'shape_Return3D_Length.cal

'Author: Ianko Tchoukanski

'http://www.ian-ko.com

On Error Resume Next

Dim pMxDoc As IMxDocument

Dim pGeometry As IGeometry

Dim pMap As IMap

Dim pCurve As ICurve

Dim dLength As Double

Dim pGeoColl As IGeometryCollection

Dim pPointColl As IPointCollection

Dim pVector As IVector3D

Dim pZAware As IZAware

Dim i As Long, j As Long

'NOTE: To get correct results the $\mathrm{Z}$ units should be the same as $\mathrm{X} \& \mathrm{Y}$

'If the data is in Decimal Degrees and $\mathrm{Z}$ is in meters, the dataframe should be projected 'and the bSrefFromMap should be TRUE

'adjust the parameters below

'bSrefFromMap = True ==> the length will be calculated in the projection of the Map

'bSrefFromMap $=$ False $==>$ the length will be calculated in the projection of the data

'bSrefFromMap needs to be True only if a real distance in Map units will be used -

bAsRatio = False

bSrefFromMap $=$ False

Set $\mathrm{pMxDoc}=$ ThisDocument

Set $\mathrm{pMap}=\mathrm{pMxDoc}$.FocusMap

If (IsNull([Shape])) Then

dLength $=-1$

Else

Set pGeometry $=[$ Shape $]$

If (pGeometry.IsEmpty) Then

dLength $=-1$

Else

Set pZAware $=$ pGeometry

If (pZAware.ZAware) Then

pGeometry.Project pMap.SpatialReference

Set $\mathrm{pGeoColl}=$ pGeometry

Set $\mathrm{pVector}=$ New Vector3D

dLength $=0$

For $\mathrm{i}=0$ To (pGeoColl.GeometryCount -1$)$ 
Set pPointColl $=$ pGeoColl.Geometry $(\mathrm{i})$

For $\mathrm{j}=0$ To (pPointColl.PointCount - 2)

pVector.ConstructDifference pPointColl.Point $(j)$, pPointColl.Point $(j+1)$

dLength $=$ dLength + pVector.Magnitude

Next j

Next $i$

Else

Set $\mathrm{pCurve}=$ pGeometry

dLength $=$ pCurve.Length

End If

End If 


\section{Visual Basic Script used to determine the slope angle of the runout path:}

'==ニ=ニ=ニ==ニ=ニ=ニ=ニ=ニ==ニ====
'polylineZ_GetSlope.cal
'Author: Ianko Tchoukanski
'http://www.ian-ko.com
'========================

On Error Resume Next

Dim pMxDoc As IMxDocument

Dim pMap As IMap

Dim pCurve As ICurve

Dim pPoint1 As IPoint, pPoint2 As IPoint

Dim dDistance1 As Double, dDistance2 As Double

Dim dDelta As Double

Dim bAsRatio As Boolean

Dim pVector As IVector3D

Dim dSlope As Double

Dim Pi As Double

Dim bSrefFromMap As Boolean

'adjust the parameters below

'bSrefFromMap = True ==> the length will be calculated in the projection of the Map 'bSrefFromMap $=$ False $==>$ the length will be calculated in the projection of the data 'bSrefFromMap needs to be True only if a real distance in Map units will be used bAsRatio = False bSrefFromMap $=$ False dDistance $1=0$ \# 'Indicates the start point of the line. Change the value to perform calculations for a different point. bAsRatio $=$ True ' the distance above will be used as a ratio from the total length. Change to false to input an absolute distance.

$\mathrm{dDelta}=0.000001$ 'A small tolerance - no change of slope expected within this tolerance

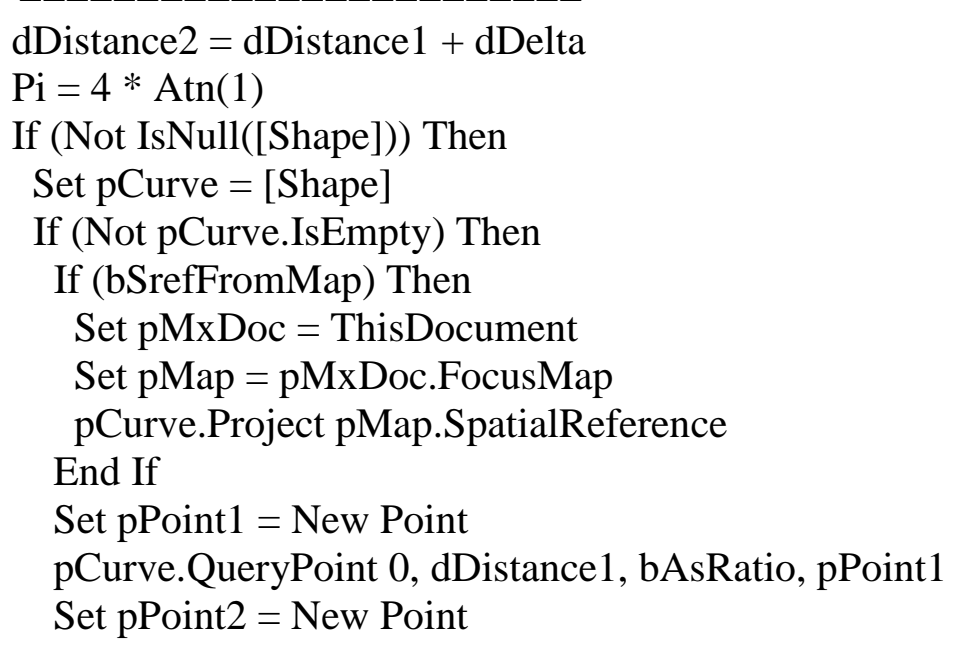


pCurve.QueryPoint 0, dDistance2, bAsRatio, pPoint2

Set $\mathrm{pVector}=$ New Vector3D

pVector.ConstructDifference pPoint2, pPoint1

$\mathrm{d}$ Slope $=\mathrm{pVector}$.Inclination

dSlope $=\mathrm{dSlope} * 360 /(2 * \mathrm{Pi})$

End If

End If

Visual Basic Script used to determine the elevation difference in the start and end of the runout path:

'Z difference Start and End.cal

'Author: Andrew Rae, Victoria University

'Date: April 2009

'Purpose: To determine the elevation of the point at the start and end of a line

Pre-Logic VBA Script Code:

Dim dblHeight1 as double

Dim dblHeight2 as double

Dim pCurve as ICurve

Set pCurve $=[$ shape $]$

dblHeight $1=$ pCurve.FromPoint. $Z$

dblHeight $2=$ pCurve.ToPoint. $Z$

Elevation Difference $=$ abs(dblHeight1-dblHeight2) 


\section{Python Script to Determine Aspect of the Earthflow Scars}

$\#-$

\# Calc_Aspect.py

\# Author: Andrew Rae Victoria University

\# Date: April 2009

\# Purpose: Assigns a value to the based on the largest part of a polygon.

\# Usage: python ...../calc_extents.py <in file>

\# Featureclass must be a polygon feature and have a field called Area,ID_1, and GRIDCODE

\# The script has been written for use with data that has been intersected with another \# data set and you need to maintain some of the original attributes.

\#

import arcgisscripting, sys

$\mathrm{gp}=$ arcgisscripting.create ()

inputFC $=$ sys.argv[1]

\#inputFC = r'D:Itemp\KatielIntersect_Copy.shp'

$\#$

\# The shapefile has to have a GRIDECODE field, an Area field and

\# an id_1 field

\#-

gridcodeField = 'GRIDCODE'

idField = 'ID_1'

areaField $=$ 'Area'

\#gp. Workspace = r'D: Itemp $\backslash$ Katie' $^{\prime}$

\#--

\# Set up a dictionary

\# The keys are the id values

\# The values are a list

\# first value in the list is the area field, second value is from the GRIDCODE filed

\#--

$d=\{\}$

\#-

\# Create the search cursor

\#--

cur1 = gp.SearchCursor(inputFC)

row1 $=$ cur1.Next ()

while row1:

\#-

\# Check to see if the id_1 field and see if it is a key in the 
\# dictionary if not add it to the dictionary

\#--------------------------------------------------------------------

$\mathrm{id}=$ row1.ID_1

if d.has_key(id):

\#-

\# Check if the polygon area is larger than the previous polygon

\# if so then set the values in the dictionary list for area

$\#$ and grid code to the current polygon.

\#---

if $\mathrm{d}[\mathrm{id}][0]$ < row1.Area:

$\mathrm{d}[\mathrm{id}]=[$ row1.Area, row1.GRIDCODE $]$

else:

$\mathrm{d}[\mathrm{id}]=[$ row1.Area, row1.GRIDCODE $]$

row $1=\operatorname{cur} 1 . \operatorname{Next}()$

del cur1

\#-------------------------------------------------------------------

\# Set an update cursor which loops through all the polygons.

\# The ID_1 field value is used to access the dictionary

\# lists.

\# The GRIDECODE is then set to the second item in the list

\#-----------------------------------------------------

cur2 = gp.UpdateCursor(inputFC)

row $2=\operatorname{cur} 2$. Next ()

while row2:

row2.GRIDCODE = d[row2.ID_1][1]

cur2.UpdateRow(row2)

row2 $=\operatorname{cur} 2 \cdot \operatorname{Next}()$

del cur2

del gp 
Appendix B: Multiple Regression Analysis

$129 \mid K . E . J o n e s$ 


\section{Raw Data for Hinenui Earthflows - Scar and Morphometic Properties}

\begin{tabular}{|c|c|c|c|c|c|c|c|c|}
\hline $\begin{array}{c}\text { Scar } \\
\text { ID }\end{array}$ & $\begin{array}{c}\text { Scar } \\
\text { Storage } \\
(\%)\end{array}$ & $\begin{array}{c}\text { Slope } \\
\text { Storage } \\
(\%)\end{array}$ & $\begin{array}{c}\text { Delivery } \\
(\%)\end{array}$ & $\begin{array}{c}\text { Scar } \\
\text { Length } \\
\text { (m) }\end{array}$ & $\begin{array}{c}\text { Volume } \\
\left(\mathbf{m}^{3}\right)\end{array}$ & $\begin{array}{c}\text { Slope } \\
\text { Runout } \\
\left({ }^{\circ}\right)\end{array}$ & $\begin{array}{c}\text { Runout } \\
\text { Length } \\
\text { (m) }\end{array}$ & $\begin{array}{c}\text { Evevation } \\
\text { Change } \\
\text { Runout (m) }\end{array}$ \\
\hline 1 & 35 & 55 & 10.0 & 38.7 & 35.1 & 23.7 & 105.0 & 24.0 \\
\hline 2 & 45 & 50 & 5.0 & 21.5 & 13.5 & 15.1 & 59.0 & 10.0 \\
\hline 3 & 5 & 80 & 15.0 & 86.0 & 88.2 & 16.1 & 71.0 & 14.0 \\
\hline 4 & 5 & 65 & 30.0 & 90.8 & 199.4 & 14.5 & 61.0 & 13.0 \\
\hline 5 & 10 & 70 & 20.0 & 90.8 & 213.6 & 15.1 & 62.0 & 16.0 \\
\hline 6 & 50 & 40 & 10.0 & 28.2 & 21.7 & 16.3 & 71.0 & 21.0 \\
\hline 7 & 85 & 15 & 0.0 & 35.4 & 31.3 & 25.7 & 40.0 & 10.0 \\
\hline 8 & 5 & 60 & 35.0 & 22.5 & 16.2 & 14.6 & 15.0 & 3.0 \\
\hline 9 & 5 & 60 & 35.0 & 47.9 & 78.9 & 25.8 & 41.0 & 13.0 \\
\hline 10 & 25 & 75 & 0.0 & 12.0 & 4.6 & 38.7 & 49.0 & 18.0 \\
\hline 11 & 80 & 20 & 0.0 & 25.8 & 16.0 & 22.6 & 45.0 & 16.0 \\
\hline 12 & 70 & 30 & 0.0 & 14.6 & 6.8 & 21.9 & 58.0 & 20.0 \\
\hline 13 & 10 & 90 & 0.0 & 35.9 & 32.1 & 2.1 & 75.0 & 25.0 \\
\hline 14 & 5 & 95 & 0.0 & 15.9 & 8.2 & 15.4 & 91.0 & 31.0 \\
\hline 15 & 5 & 95 & 0.0 & 22.9 & 9.4 & 22.4 & 43.0 & 13.0 \\
\hline 16 & 20 & 65 & 15.0 & 18.5 & 7.8 & 27.2 & 52.0 & 15.0 \\
\hline 17 & 40 & 30 & 30.0 & 38.3 & 34.7 & 28.5 & 28.0 & 8.0 \\
\hline 18 & 60 & 15 & 25.0 & 47.3 & 47.3 & 31.0 & 68.0 & 28.0 \\
\hline 19 & 5 & 90 & 5.0 & 54.8 & 77.5 & 38.5 & 62.0 & 26.0 \\
\hline 20 & 5 & 85 & 10.0 & 29.9 & 24.5 & 24.8 & 78.0 & 35.0 \\
\hline 20 & 28 & 30 & 25.3 & 25.3 & 67.5 & 8.8 & 30.2 & 12.5 \\
\hline 21 & 5 & 90 & 5.0 & 56.5 & 97.4 & 33.9 & 37.0 & 14.0 \\
\hline 22 & 70 & 25 & 5.0 & 21.9 & 15.5 & 30.1 & 76.0 & 36.0 \\
\hline 23 & 20 & 30 & 50.0 & 28.5 & 25.1 & 31.0 & 115.0 & 51.0 \\
\hline 24 & 85 & 15 & 0.0 & 23.6 & 12.1 & 23.7 & 110.0 & 52.0 \\
\hline 25 & 80 & 15 & 5.0 & 18.5 & 10.5 & 29.2 & 93.0 & 41.0 \\
\hline 26 & 5 & 80 & 15.0 & 103.9 & 234.4 & 21.5 & 95.0 & 43.0 \\
\hline 27 & 5 & 90 & 5.0 & 45.3 & 38.7 & 27.2 & 53.0 & 24.0 \\
\hline 28 & 0 & 50 & 50.0 & 34.9 & 36.1 & 27.7 & 25.0 & 11.0 \\
\hline 29 & 5 & 80 & 15.0 & 23.1 & 18.9 & 30.2 & 48.0 & 21.0 \\
\hline 30 & 10 & 85 & 5.0 & 61.3 & 120.1 & 29.7 & 67.0 & 33.0 \\
\hline 31 & 10 & 85 & 5.0 & 73.4 & 138.9 & 31.2 & 83.0 & 40.0 \\
\hline 32 & 5 & 85 & 10.0 & 73.0 & 144.4 & 29.5 & 46.0 & 19.0 \\
\hline 33 & 10 & 85 & 5.0 & 24.4 & 11.0 & 27.8 & 65.0 & 30.0 \\
\hline 34 & 5 & 90 & 5.0 & 39.4 & 51.0 & 28.3 & 70.0 & 35.0 \\
\hline 35 & 0 & 95 & 5.0 & 54.7 & 80.8 & 29.7 & 46.0 & 20.0 \\
\hline 36 & 26 & 53 & 21.5 & 47.0 & 69.2 & 27.4 & 58.0 & 21.6 \\
\hline 36 & 10 & 50 & 40.0 & 37.4 & 43.3 & 48.8 & 50.0 & 21.0 \\
\hline 37 & 5 & 20 & 75.0 & 70.3 & 130.0 & 38.8 & 109.0 & 45.0 \\
\hline
\end{tabular}




\begin{tabular}{|c|c|c|c|c|c|c|c|c|}
\hline $\begin{array}{l}\text { Scar } \\
\text { ID }\end{array}$ & $\begin{array}{c}\text { Scar } \\
\text { Storage } \\
(\%)\end{array}$ & $\begin{array}{c}\text { Slope } \\
\text { Storage } \\
(\%)\end{array}$ & $\begin{array}{c}\text { Delivery } \\
(\%)\end{array}$ & $\begin{array}{c}\text { Scar } \\
\text { Length } \\
(\mathrm{m})\end{array}$ & $\begin{array}{c}\text { Volume } \\
\left(\mathrm{m}^{3}\right)\end{array}$ & $\begin{array}{c}\text { Slope } \\
\text { Runout } \\
\left({ }^{\circ}\right)\end{array}$ & $\begin{array}{c}\text { Runout } \\
\text { Length } \\
\text { (m) }\end{array}$ & $\begin{array}{c}\text { Evevation } \\
\text { Change } \\
\text { Runout (m) }\end{array}$ \\
\hline 38 & 5 & 20 & 75.0 & 90.4 & 197.2 & 34.6 & 93.0 & 36.0 \\
\hline 39 & 5 & 5 & 90.0 & 46.6 & 38.4 & 45.9 & 75.0 & 30.0 \\
\hline 40 & 5 & 5 & 90.0 & 63.8 & 88.2 & 15.0 & 52.0 & 17.0 \\
\hline 41 & 40 & 60 & 0.0 & 99.9 & 217.7 & 32.2 & 27.0 & 14.0 \\
\hline 42 & 40 & 50 & 10.0 & 50.3 & 53.6 & 39.8 & 61.0 & 27.0 \\
\hline 43 & 15 & 75 & 10.0 & 37.0 & 44.2 & 11.9 & 18.0 & 4.0 \\
\hline 44 & 10 & 80 & 10.0 & 111.9 & 297.3 & 28.8 & 112.0 & 51.0 \\
\hline 45 & 5 & 50 & 45.0 & 23.0 & 16.8 & 23.0 & 61.0 & 24.0 \\
\hline 46 & 25 & 70 & 5.0 & 50.0 & 89.5 & 39.3 & 75.0 & 33.0 \\
\hline 47 & 50 & 10 & 40.0 & 16.6 & 6.0 & 31.9 & 35.0 & 13.0 \\
\hline 48 & 15 & 10 & 75.0 & 50.2 & 51.9 & 8.6 & 2.0 & 0.5 \\
\hline 49 & 5 & 90 & 5.0 & 63.9 & 93.3 & 12.4 & 5.0 & 1.0 \\
\hline 50 & 80 & 20 & 0.0 & 59.8 & 110.8 & 29.7 & 10.0 & 6.0 \\
\hline 51 & 10 & 85 & 5.0 & 20.1 & 9.8 & 34.0 & 36.0 & 15.0 \\
\hline 52 & 70 & 25 & 5.0 & 17.9 & 11.1 & 32.0 & 23.0 & 10.0 \\
\hline 53 & 10 & 90 & 0.0 & 52.4 & 59.0 & 30.9 & 12.0 & 7.0 \\
\hline 54 & 10 & 70 & 20.0 & 44.7 & 61.7 & 28.4 & 26.0 & 10.0 \\
\hline 55 & 95 & 5 & 0.0 & 41.7 & 38.0 & 26.4 & 19.0 & 10.0 \\
\hline 56 & 95 & 5 & 0.0 & 49.9 & 67.9 & 28.0 & 17.0 & 11.0 \\
\hline 57 & 5 & 95 & 0.0 & 23.9 & 15.9 & 35.2 & 3.0 & 5.0 \\
\hline 58 & 5 & 90 & 5.0 & 22.4 & 16.9 & 17.9 & 16.0 & 7.0 \\
\hline 59 & 20 & 50 & 30.0 & 30.9 & 32.4 & 27.0 & 29.0 & 13.0 \\
\hline 60 & 5 & 80 & 15.0 & 42.8 & 58.2 & 43.0 & 45.0 & 19.0 \\
\hline 61 & 20 & 40 & 40.0 & 58.7 & 80.5 & 28.0 & 51.0 & 23.0 \\
\hline 62 & 20 & 20 & 60.0 & 54.7 & 76.9 & 37.1 & 41.0 & 18.0 \\
\hline 63 & 10 & 35 & 55.0 & 83.1 & 162.0 & 21.6 & 34.0 & 16.0 \\
\hline 64 & 50 & 40 & 10.0 & 118.5 & 285.5 & 45.1 & 17.0 & 7.0 \\
\hline 65 & 0 & 5 & 95.0 & 44.0 & 55.1 & 23.5 & 95.0 & 28.0 \\
\hline 66 & 5 & 20 & 75.0 & 52.8 & 72.8 & 28.6 & 82.0 & 26.0 \\
\hline 67 & 10 & 60 & 30.0 & 30.1 & 24.4 & 24.7 & 109.0 & 39.0 \\
\hline 68 & 70 & 25 & 5.0 & 60.6 & 91.1 & 29.0 & 117.0 & 38.0 \\
\hline 69 & 20 & 40 & 40.0 & 16.0 & 8.5 & 32.5 & 97.0 & 29.0 \\
\hline 70 & 40 & 45 & 15.0 & 71.9 & 97.5 & 29.1 & 89.0 & 25.0 \\
\hline 71 & 50 & 30 & 20.0 & 69.1 & 107.2 & 30.6 & 91.0 & 24.0 \\
\hline
\end{tabular}




\section{Liquid Limit of the Hinenui Catchment}
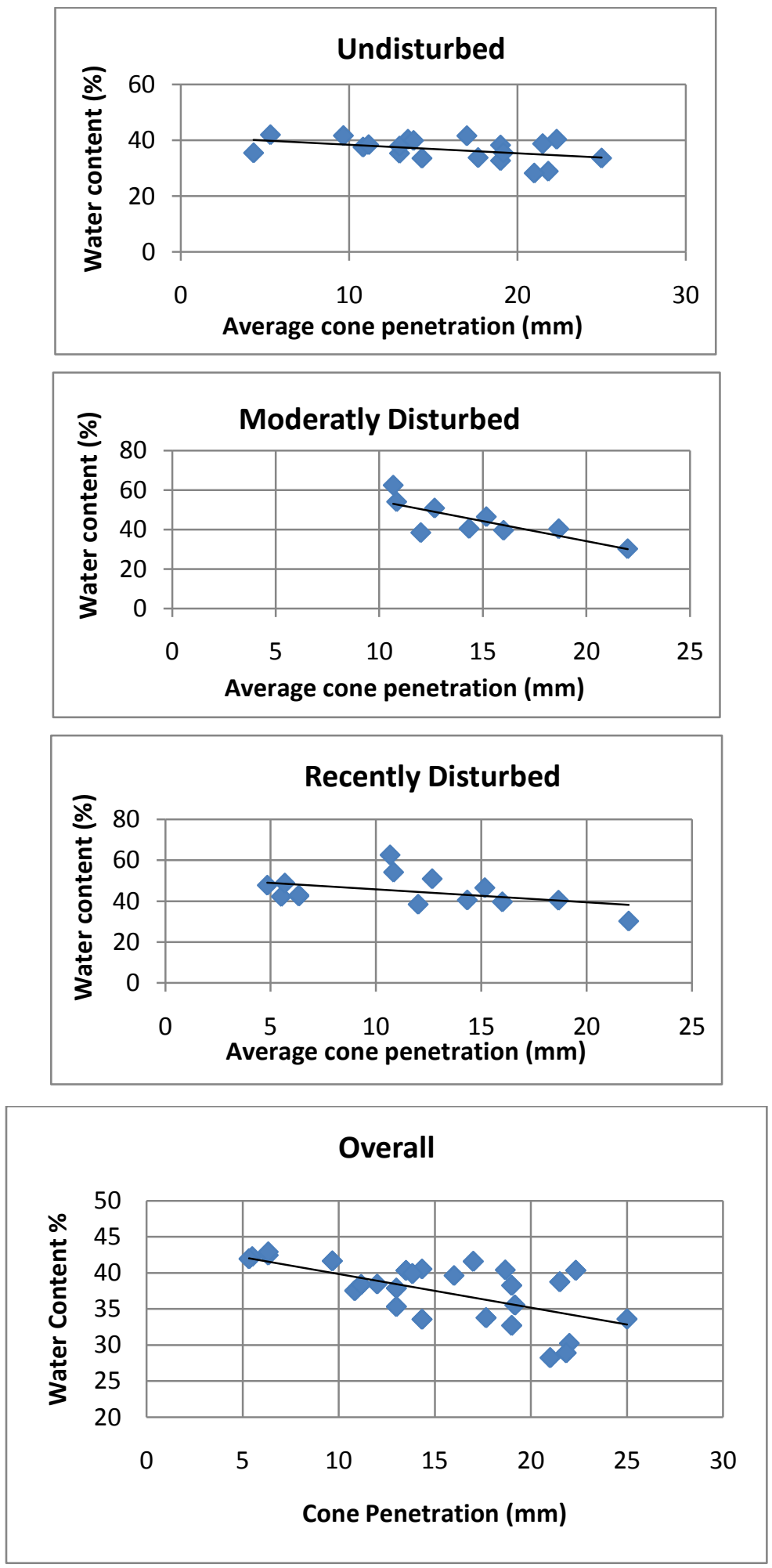

Overall liquid limit was determined at $35 \%$ for the Hinenui Catchment 


\section{Location and Runouth Paths of the Hinenui Earthflows}

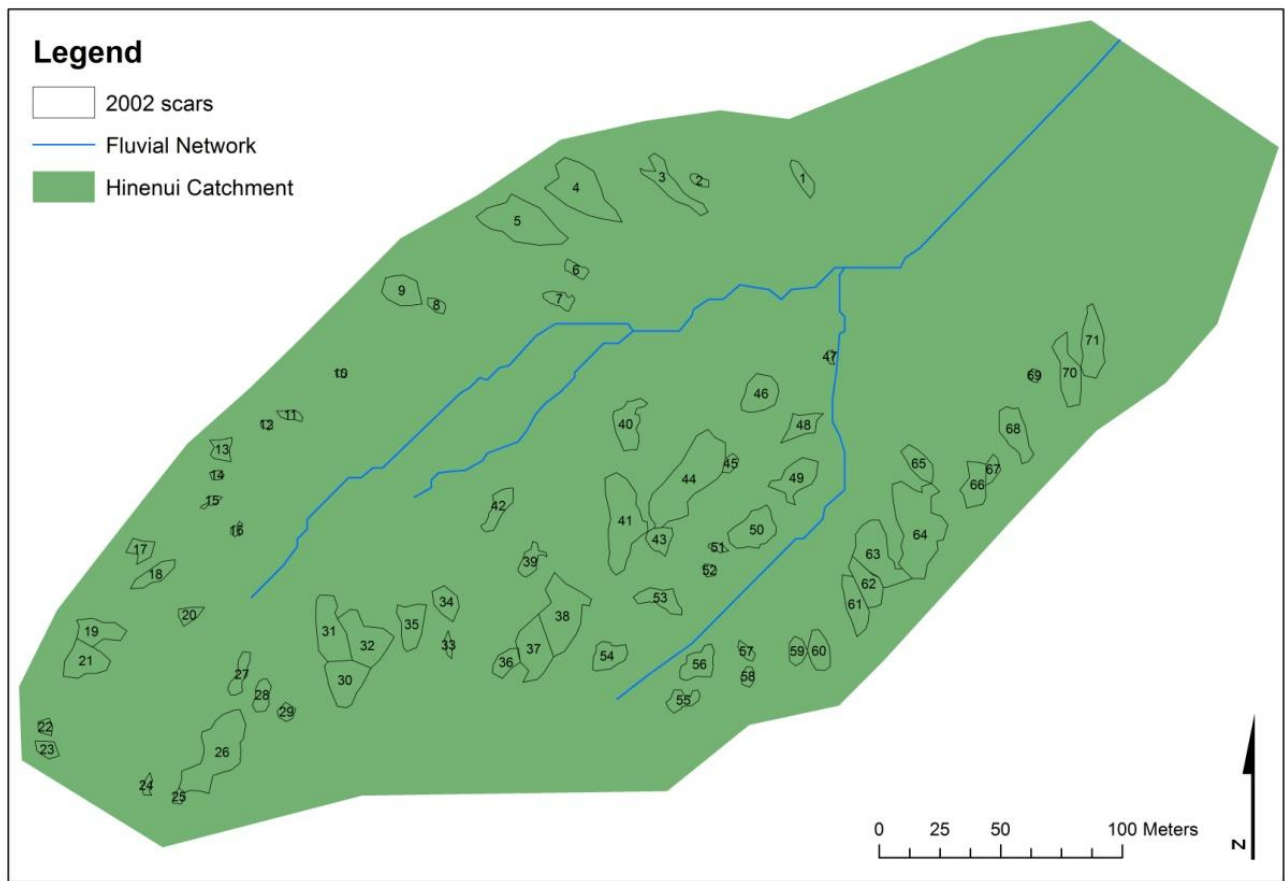

The 71 earthflow scars at the Hinenui catchment triggered in 2002.

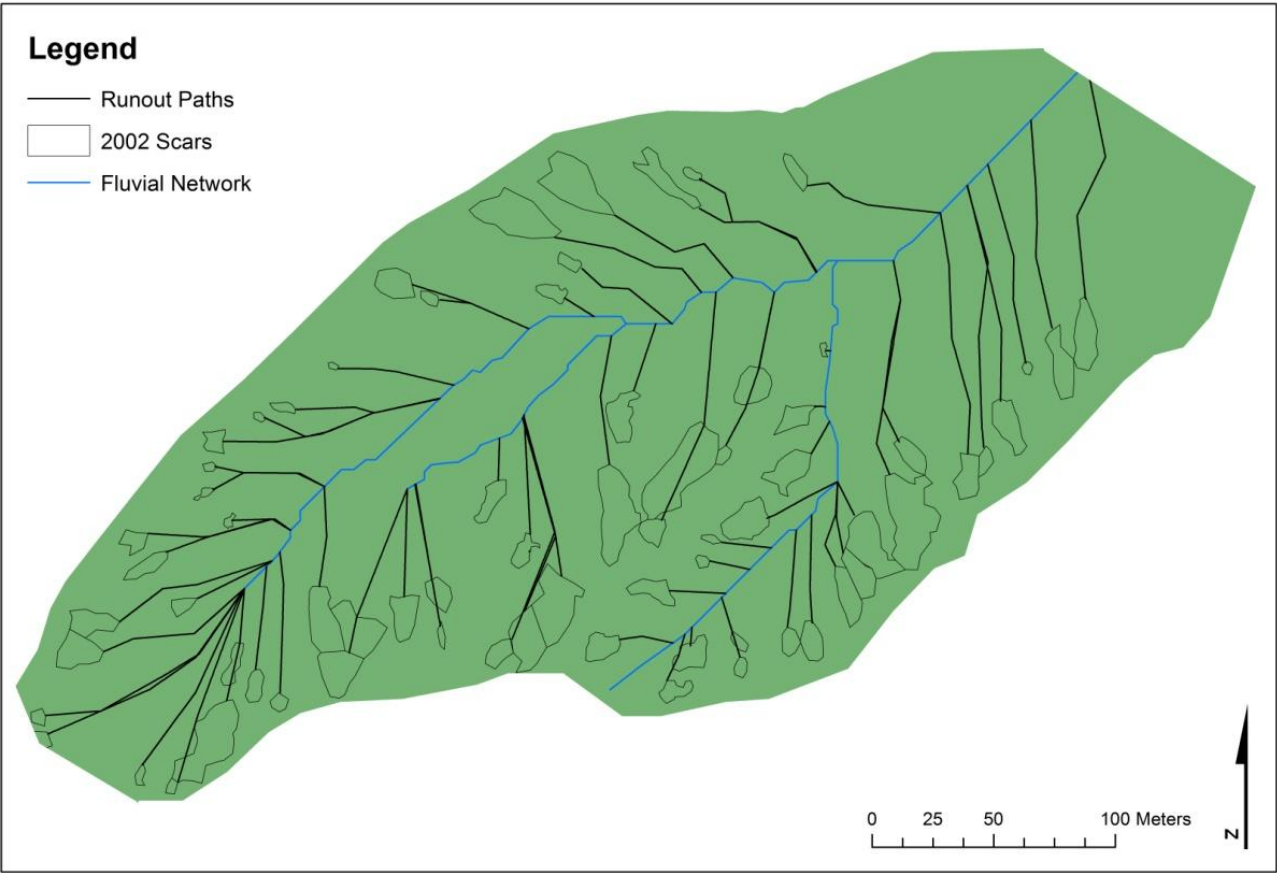

Runout paths of the 71 earthflow scars at Hinenui. 


\section{Spatial Pattern to Sediment Distribution}

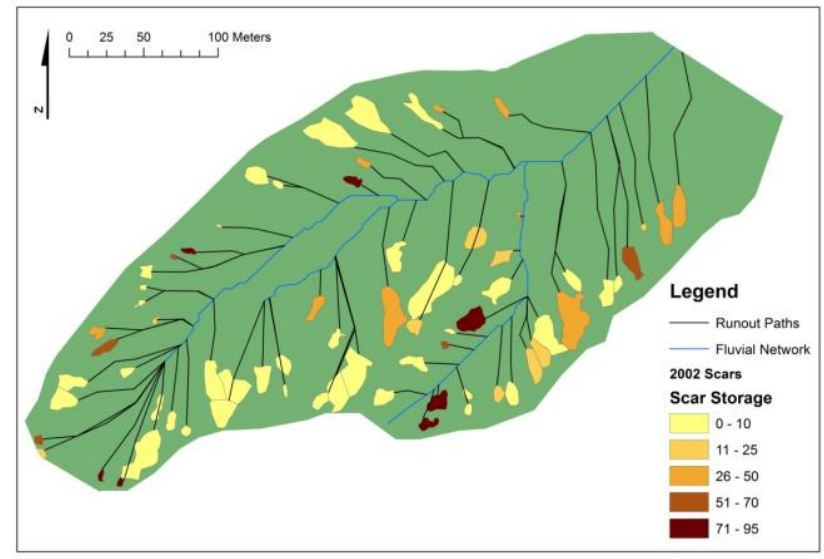

Spatial pattern to Scar Storage at Hinenui.

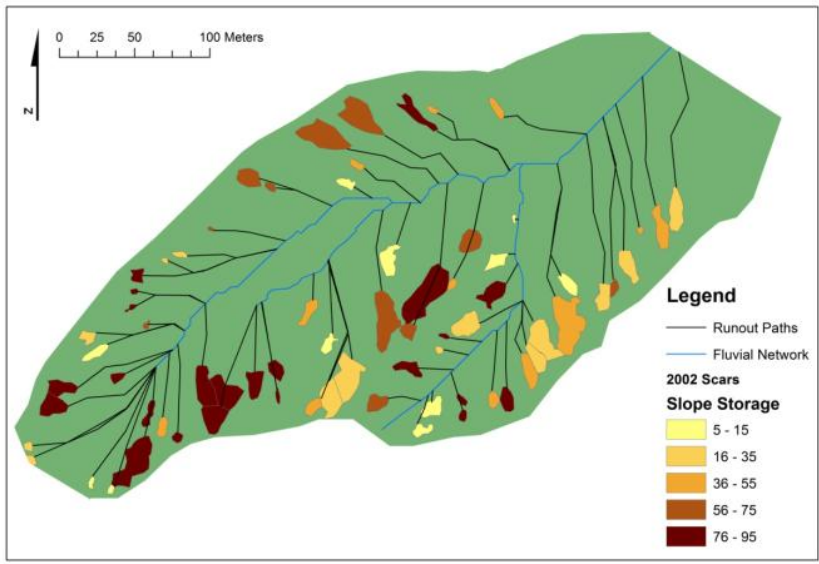

Spatial pattern to slope storage at Hinenui.

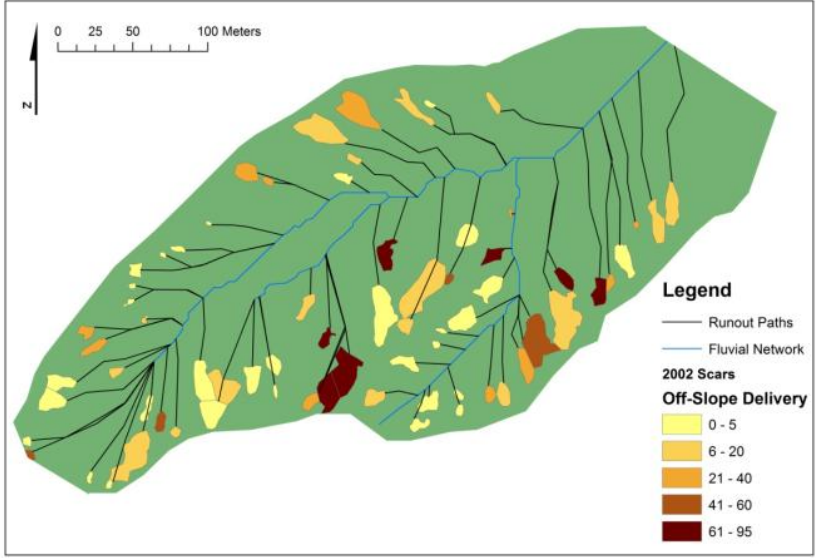

Spatial patterns to off-slope sediment delivery at Hinenui. 


\section{Morphology of the Hinenui Catchment}

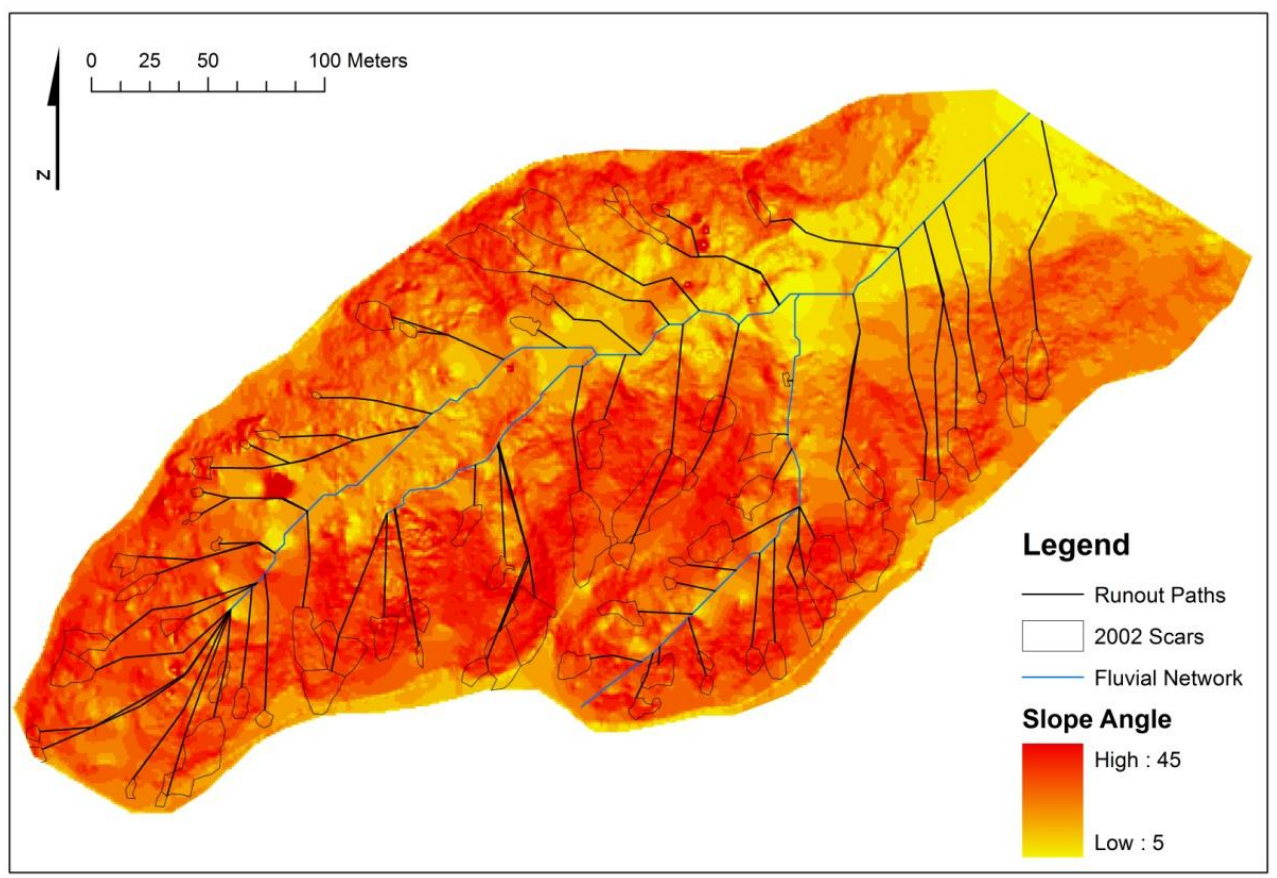

Slope angles of the Hinenui Catchment.

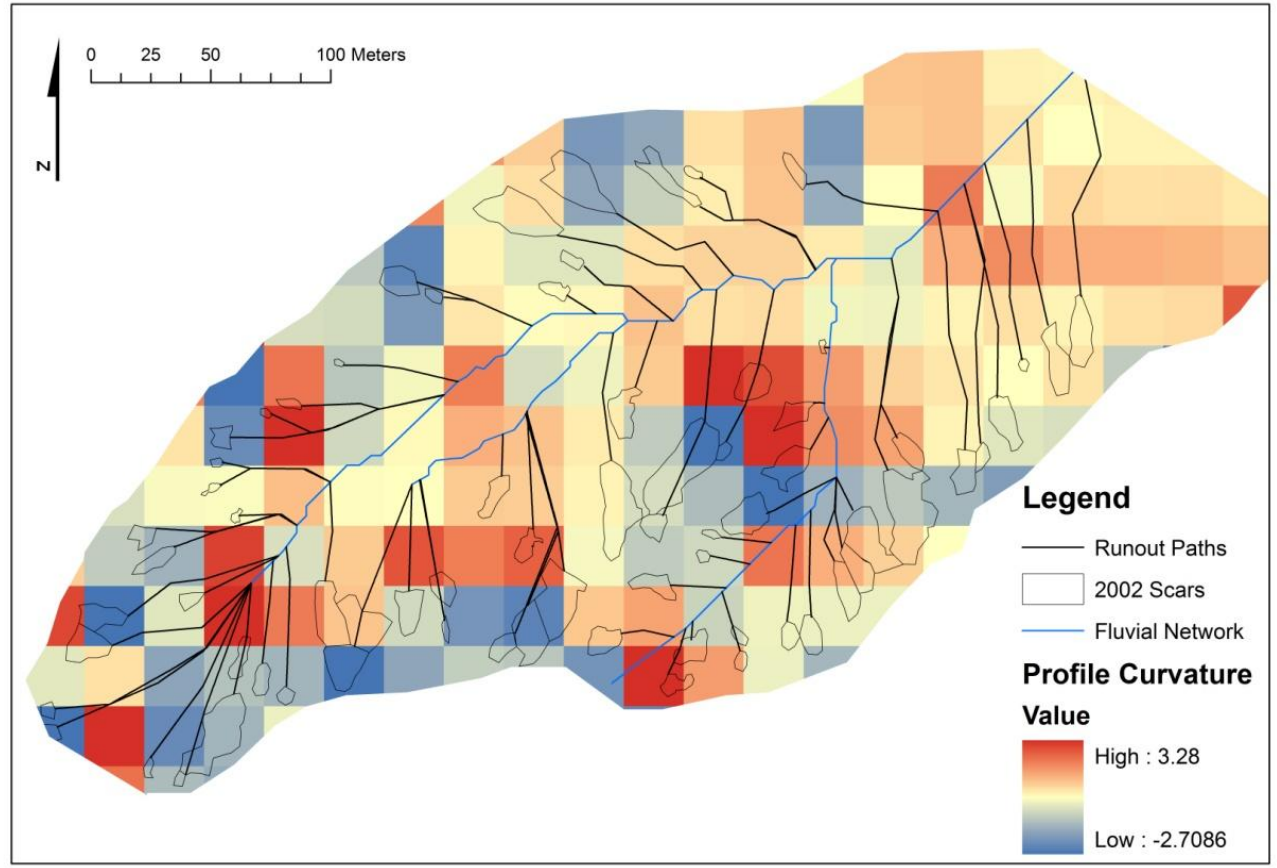

Profile curvature of the Hinenui catchment. 


\section{Multlple Regression Modelling Sediment Delivery Ratios for all Earthflows}

SQRT_Ds $=3.23271+0.408425 * C r-3.1156 * L O G \_L s+3.07101 * L O G \_V s+$ $0.0412901 * L r-0.709185 * S Q R T \_E r+0.0407677 * S r$

$R^{2}=0.096$

$P$-value $=0.354$

Std. Error $=2.12$

SQRT_Ds $=0.810248+0.363697 * C r+1.43784 * L O G_{-} V s+0.0386576 * L r-$ $0.652059 * S Q R T \_E r+0.0402349 * S r$

$P$-value $=0.257$

Std. Error $=2.76$

SQRT_Ds $=0.864129+1.41703 * L O G_{-} V s+0.0376012 * L r-0.609305 * S Q R T \_E r$ $+0.0382551 * S r$

$$
R^{2}=0.089
$$

$P$-value $=0.181$

Std. Error $=2.75$

$S Q R T \_D s=1.2414+1.45691 * L O G \_V s+0.0257658 * L r-0.316981 * S Q R T \_E r$

$$
\begin{array}{r}
R^{2}=0.079 \\
P \text {-value }=0.137 \\
\text { Std. Error }=2.74
\end{array}
$$

SQRT_Ds $=0.670724+1.42806 * L O G \_V s+0.012267 * L r$

$$
R^{2}=0.074
$$$$
P \text {-value }=0.074
$$

Std. Error $=2.73$

SQRT_Ds $=1.34765+1.44959 * L O G_{-} V s$

$$
R^{2}=0.056
$$

$P$-value $=0.047$

Std. Error $=2.74$ 


\section{Multlple Regression Modelling Sediment Delivery Ratios for Connected Earthflows}

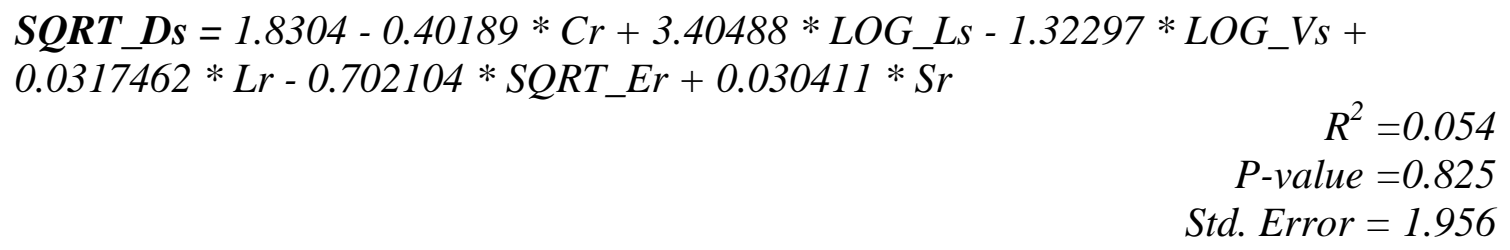

SQRT_Ds $=3.61949-0.356214 * C r+0.979764 * L O G \_L s+0.0338943 * L r-$ $0.749204 * S Q R T \_E r+0.0310025 * S r$

$$
R^{2}=0.052
$$

$P$-value $=0.733$

Std. Error $=2.393$

SQRT_Ds $=3.53826+0.990571 * L O G \_L s+0.0343166 * L r-0.762489 * S Q R T \_E r$ $+0.030721 * \mathrm{Sr}$

SQRT_Ds $=5.4242-0.55198 * S Q R T \_E r+0.0282666 * L r$

SQRT_Ds $=4.34001+0.00465334 * \mathrm{Lr}$ 


\section{Multlple Regression Modelling \\ Runout Length for all Earthflows}

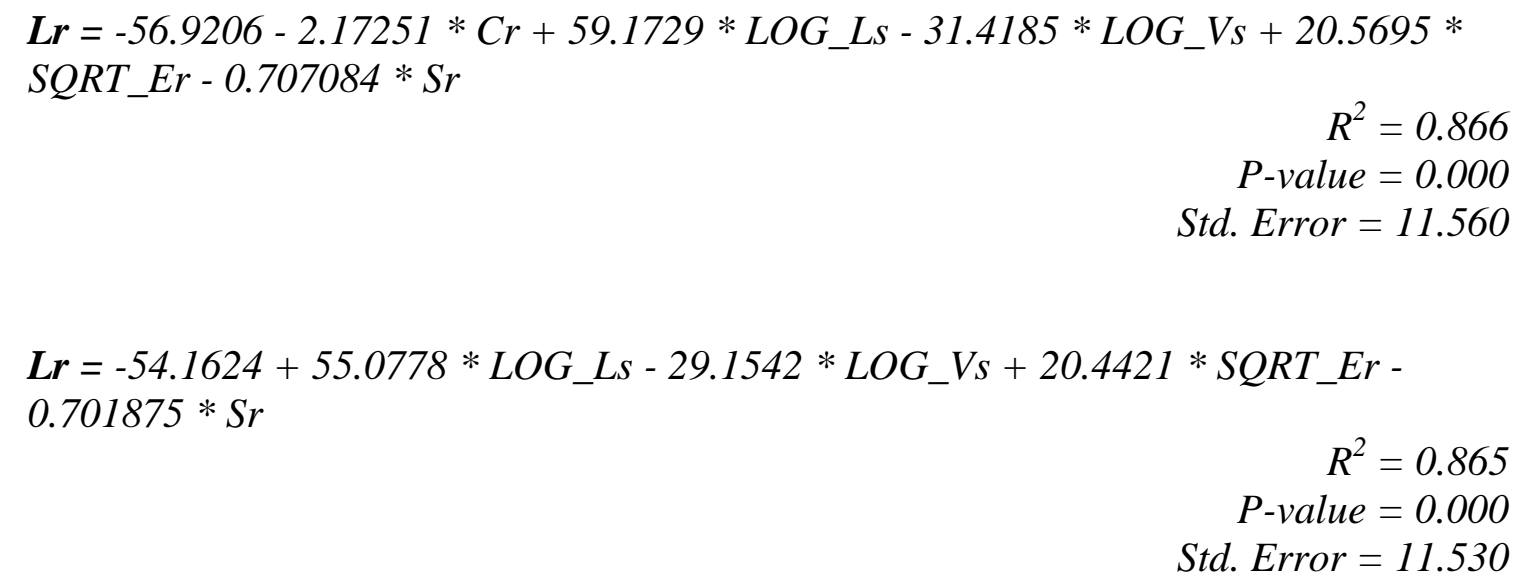

$R^{2}=0.866$

$P$-value $=0.000$

Std. Error $=11.560$

$\boldsymbol{L r}=-54.1624+55.0778 * L O G \_L s-29.1542 * L O G \_V s+20.4421 * S Q R T \_E r-$ $0.701875 * \mathrm{Sr}$

$$
\begin{aligned}
R^{2} & =0.865 \\
P \text {-value } & =0.000
\end{aligned}
$$$$
\text { Std. } \text { Error }=11.530
$$

$$
\begin{array}{r}
\text { Lr }=-14.0352+1.1628 * \text { LOG_Ls }+20.4202 * \text { SQRT_Er }-0.732508 * \text { Sr } \\
R^{2}=0.858 \\
P \text {-value }=0.000 \\
\text { Std. Error }=11.703
\end{array}
$$

$$
\mathbf{L r}=-12.2451+20.4257 * \mathrm{SQRT} \_\mathrm{Er}-0.73048 * \mathrm{Sr}
$$

$$
\begin{array}{r}
R^{2}=0.858 \\
P \text {-value }=0.000 \\
\text { Std. Error }=11.620
\end{array}
$$

$\boldsymbol{L r}=-26.658+19.1613 * S Q R T \_E r$

$$
\begin{array}{r}
R^{2}=0.817 \\
P \text {-value }=0.000 \\
\text { Std. Error }=10.990
\end{array}
$$

Excluding Change in Elevation (Er) Variable:

$$
\begin{aligned}
& \boldsymbol{L r}=18.5558+6.20124 * C r+38.6313 * L O G_{-} L s-18.4711 * L O G_{-} V s+0.214411 * \\
& S r \\
& R^{2}=0.020 \\
& P \text {-value }=0.849 \\
& \text { Std. Error }=31.019
\end{aligned}
$$




\section{Multlple Regression Modelling \\ Scar Length for all Earthflows}

$\boldsymbol{L O G} \_\boldsymbol{L} \boldsymbol{s}=0.777527+0.0143564 * C r+0.524192 * L O G \_V s+0.00084493 * L r-$ $0.0183357 * S Q R T \_E r+0.000171022 * S r$

$$
\begin{array}{r}
R^{2}=0.970 \\
P \text {-value }=0.000 \\
\text { Std. Error }=0.044
\end{array}
$$

$\boldsymbol{L O G} \_\boldsymbol{L} \boldsymbol{s}=0.779232+0.0141674 * C r+0.524358 * L O G \_V s+0.000791788 * L r-$ $0.0170145 * S Q R T \_E r$

$$
\begin{aligned}
R^{2} & =0.970 \\
P \text {-value } & =0.000 \\
\text { Std. Error } & =0.043
\end{aligned}
$$

$\boldsymbol{L O G \_ L s}=0.78057+0.523467 * L O G \_V s+0.000774497 * L r-0.0159384 *$ SQRT_Er

$$
\begin{aligned}
R^{2} & =0.970 \\
P \text {-value } & =0.000 \\
\text { Std. Error } & =0.044
\end{aligned}
$$

$\boldsymbol{L O G} \_\boldsymbol{L s}=0.751875+0.522017 * L O G \_V s+0.0000957547 * L r$

$$
\begin{aligned}
R^{2} & =0.967 \\
P \text {-value } & =0.000 \\
\text { Std. Error } & =0.045
\end{aligned}
$$

$\boldsymbol{L O G \_ L s}=0.751875+0.522017 * L O G \_V s+0.0000957547 * L r$

$$
\begin{array}{r}
R^{2}=0.967 \\
P \text {-value }=0.000 \\
\text { Std. Error }=0.444
\end{array}
$$




\section{Appendix C: Sediment Delivery Ratios}

$140 \mid K . E$. J o n e s 
Sediment Delivery Ratios

Using individual ratio of 50\% for Connected Scars

\begin{tabular}{|c|c|c|c|c|c|c|c|c|c|}
\hline \multicolumn{10}{|c|}{ Waimoa Catchment } \\
\hline $\begin{array}{c}\text { Nested } \\
\text { Catchment }\end{array}$ & & & 1952 & 1965 & 1974 & 1980 & 1984 & & 2004 \\
\hline 1 & & & 28 & 43 & 39 & 47 & 42 & & 41 \\
\hline 2 & & & 33 & 74 & 52 & 46 & 43 & & 41 \\
\hline 3 & & & 45 & 60 & 42 & 68 & 49 & & 55 \\
\hline 4 & & & 39 & 58 & 44 & 46 & 46 & & 42 \\
\hline 5 & & & 29 & 32 & 17 & 34 & 31 & & 32 \\
\hline \multicolumn{10}{|c|}{ Ahioteatua Catchment A } \\
\hline $\begin{array}{c}\text { Nested } \\
\text { Catchment }\end{array}$ & 1943 & & 1952 & 1969 & & 1982 & & 1988 & 2004 \\
\hline 1 & 39 & & 45 & 43 & & 47 & & 49 & 29 \\
\hline 2 & 43 & & 45 & 47 & & 46 & & 48 & 33 \\
\hline 3 & 42 & & 46 & 46 & & 45 & & 47 & 32 \\
\hline 4 & 41 & & 46 & 46 & & 45 & & 33 & 29 \\
\hline 5 & 31 & & 34 & 35 & & 34 & & & 21 \\
\hline \multicolumn{10}{|c|}{ Ahioteatua Catchment B } \\
\hline $\begin{array}{c}\text { Nested } \\
\text { Catchment }\end{array}$ & 1943 & & 1952 & 1969 & & 1982 & & 1988 & 2004 \\
\hline 1 & 43 & & 25 & 35 & & 46 & & 22 & 26 \\
\hline 2 & 44 & & 33 & 37 & & 62 & & 43 & 28 \\
\hline 3 & 43 & & 36 & 37 & & 70 & & 34 & 25 \\
\hline 4 & 42 & & 39 & 38 & & 73 & & 36 & 27 \\
\hline 5 & 30 & & 29 & 24 & & 32 & & 52 & 21 \\
\hline \multicolumn{10}{|c|}{ Mangakiore Catchment A } \\
\hline $\begin{array}{c}\text { Nested } \\
\text { Catchment }\end{array}$ & & 1949 & & 1965 & 1974 & & & 1988 & 2004 \\
\hline 1 & & 31 & & 45 & 48 & & & 48 & 35 \\
\hline 2 & & 32 & & 43 & 48 & & & 47 & 33 \\
\hline 3 & & 34 & & 44 & 48 & & & 48 & 38 \\
\hline 4 & & 39 & & 45 & 46 & & & 48 & 37 \\
\hline 5 & & 30 & & 27 & 35 & & & 36 & 23 \\
\hline \multicolumn{10}{|c|}{ Mangakiore Catchment B } \\
\hline $\begin{array}{c}\text { Nested } \\
\text { Catchment }\end{array}$ & & 1949 & & 1965 & 1974 & & & 1988 & 2004 \\
\hline 1 & & 44 & & 45 & 43 & & & 46 & 35 \\
\hline 2 & & 44 & & 45 & 43 & & & 46 & 39 \\
\hline 3 & & 43 & & 46 & 43 & & & 46 & 39 \\
\hline 4 & & 44 & & 46 & 42 & & & 47 & 37 \\
\hline 5 & & 35 & & 19 & 30 & & & 34 & 28 \\
\hline
\end{tabular}




\section{Spatial Trends in Sediment Delivery Ratios \\ Waimoa Catchment}
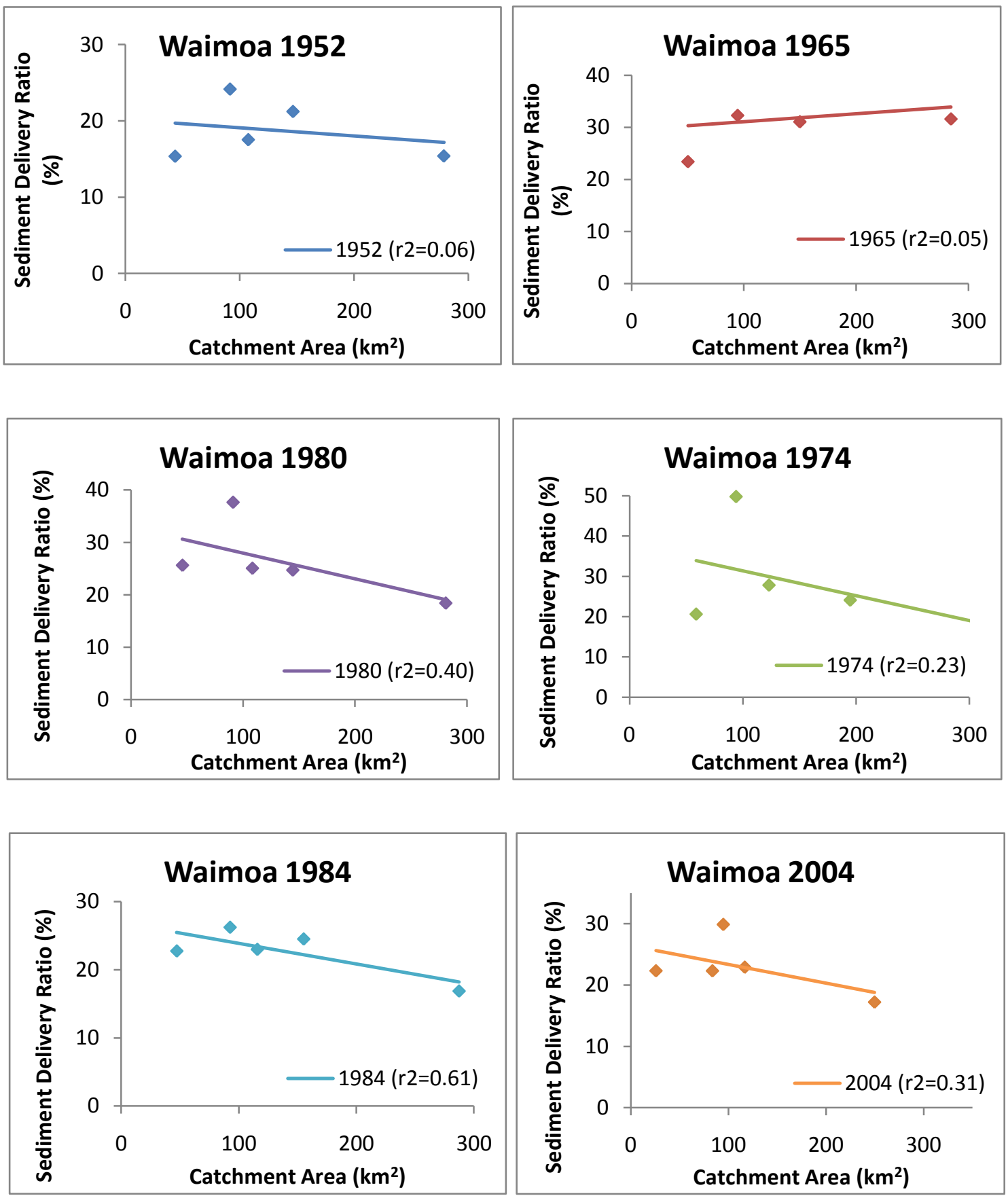


\section{Spatial Trends in Sediment Delivery Ratios Ahioteatua Catchment A}
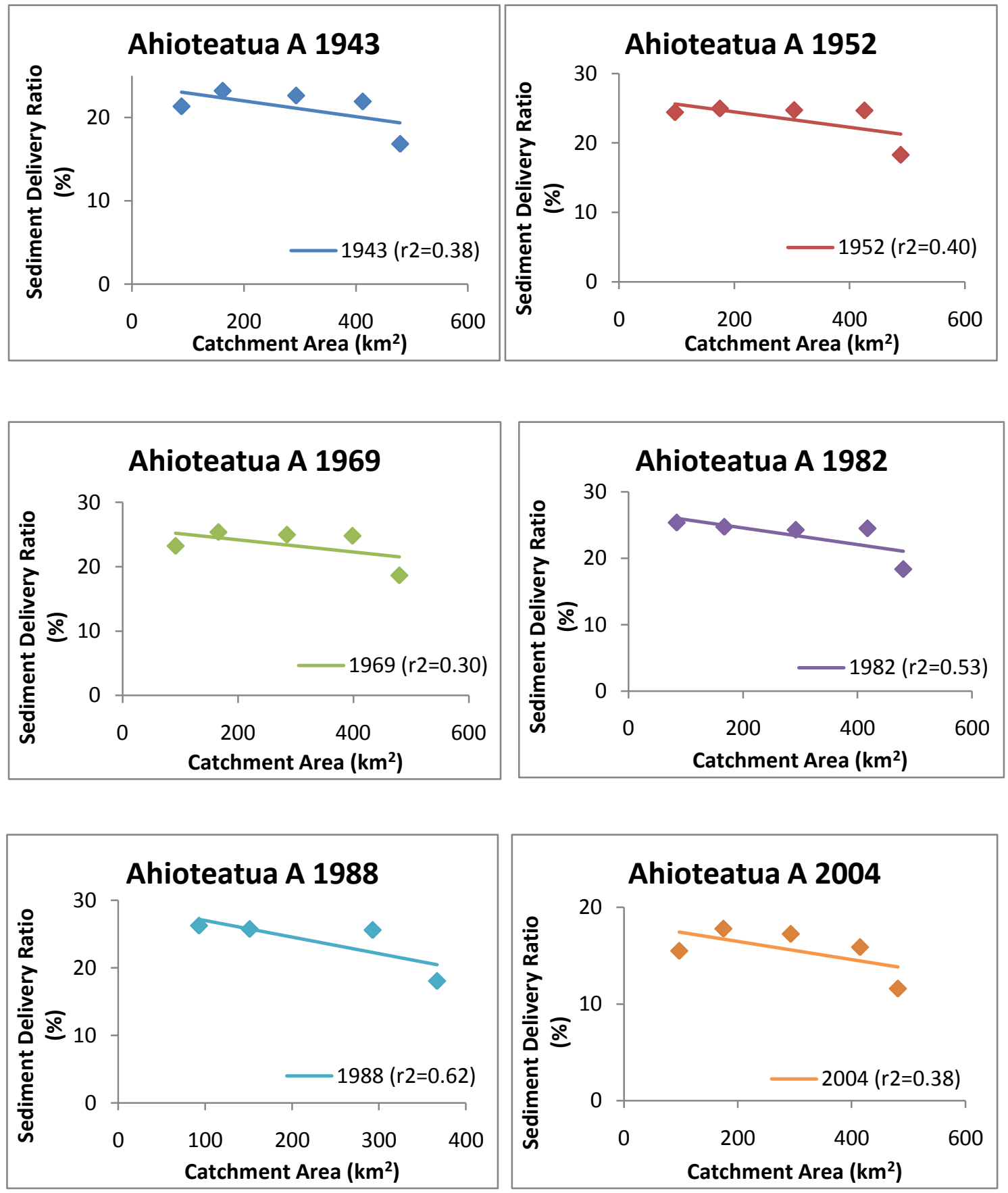


\section{Spatial Trends in Sediment Delivery Ratios \\ Ahioteatua Catchment B}
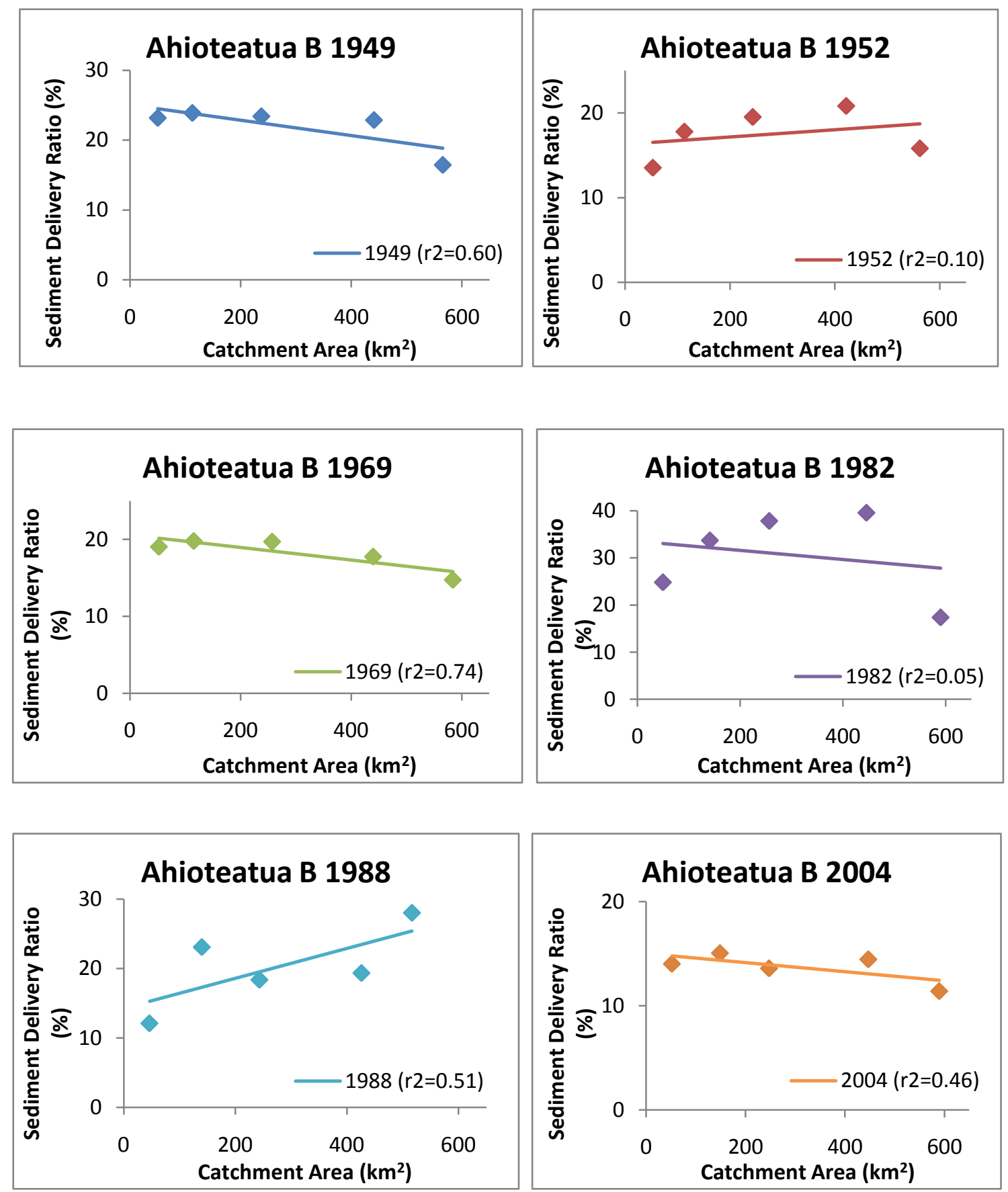


\section{Spatial Trends in Sediment Delivery Ratios \\ Mangakiore Catchment A}
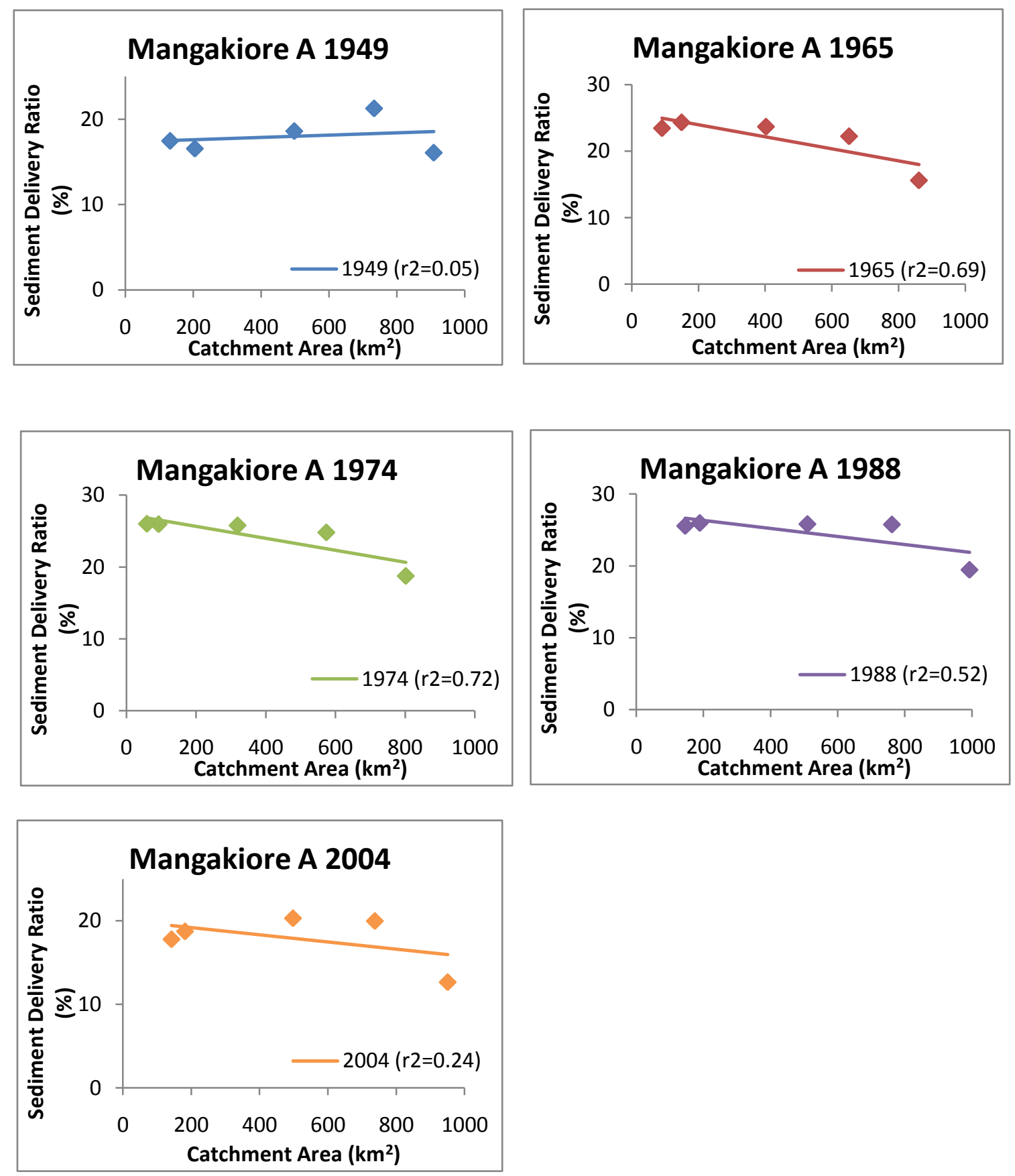


\section{Spatial Trends in Sediment Delivery Ratios Mangakiore Catchment B}
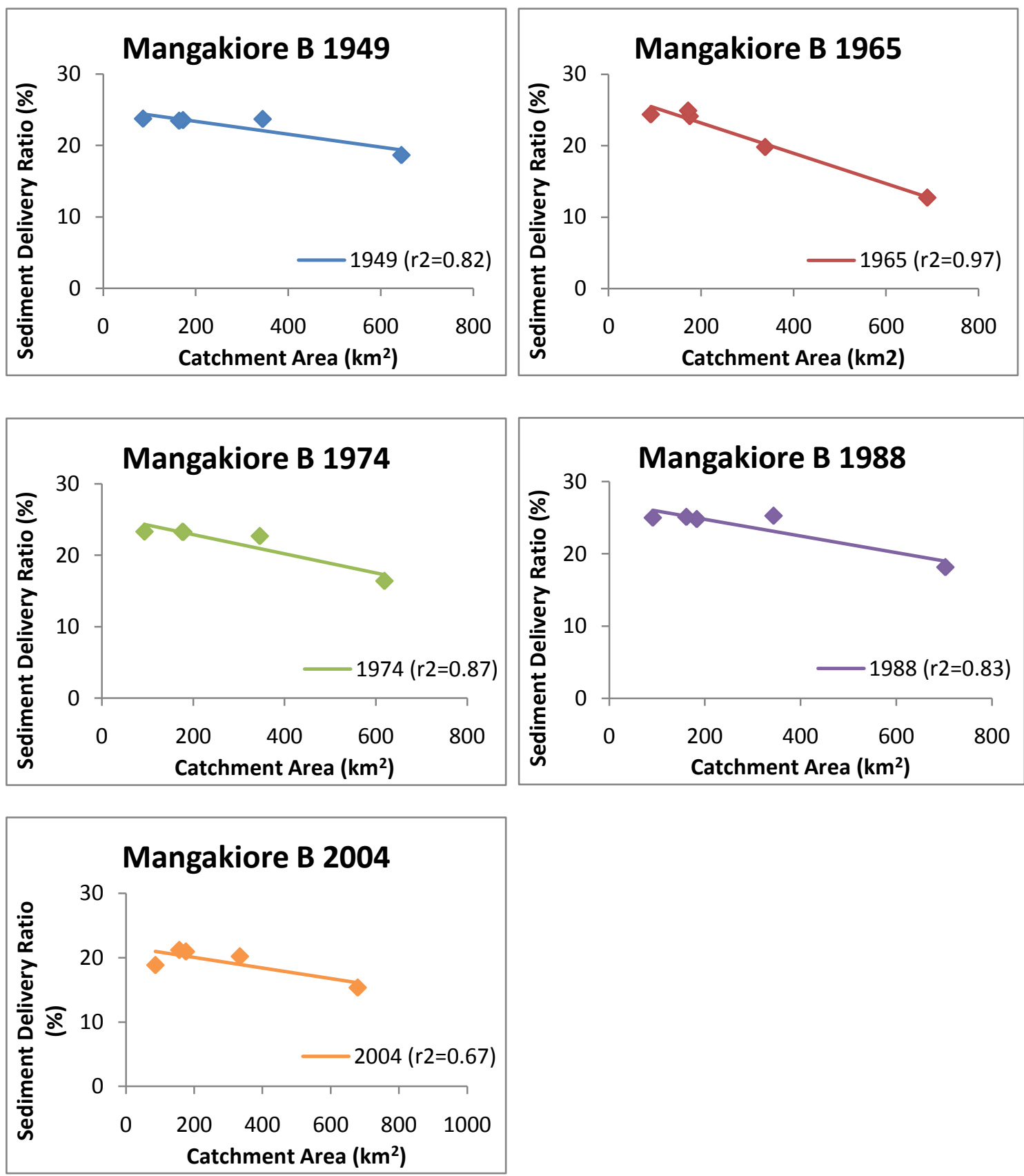


\section{Temporal Trends in Sediment Delivery Ratios Waimoa Catchment}
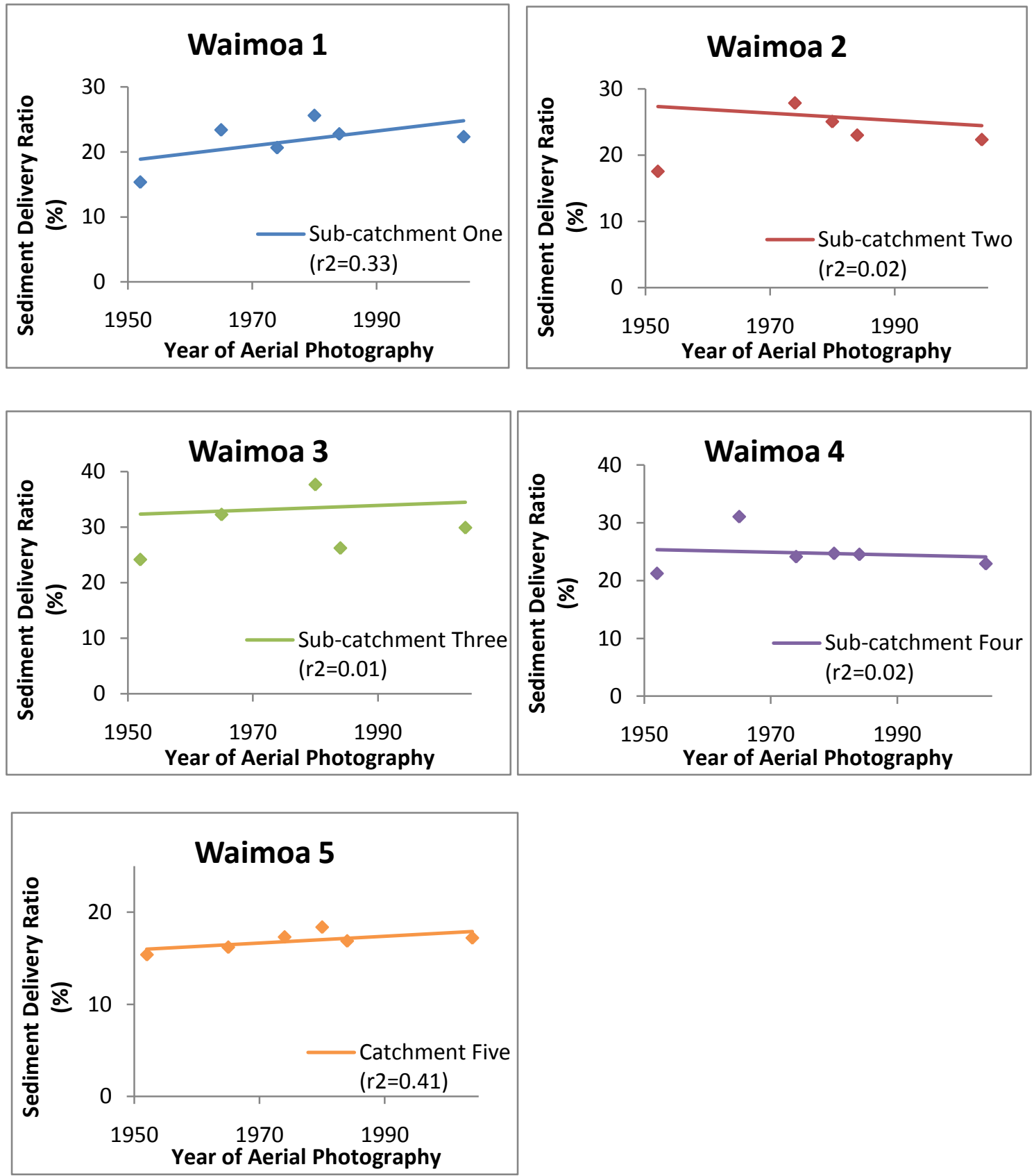


\section{Temporal Trends in Sediment Delivery Ratios Ahioteatua Catchment A}
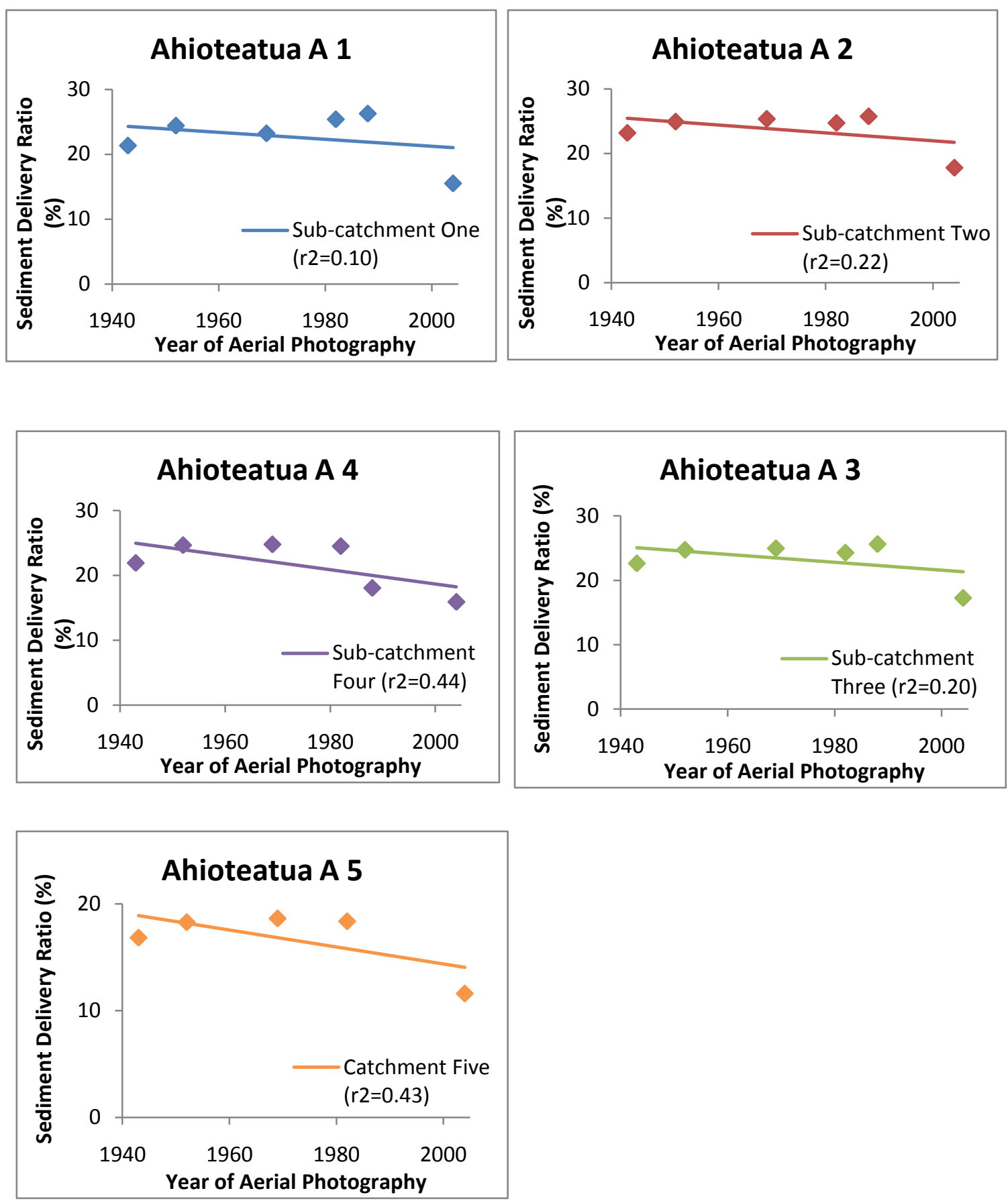


\section{Temporal Trends in Sediment Delivery Ratios Ahioteatua Catchment B}
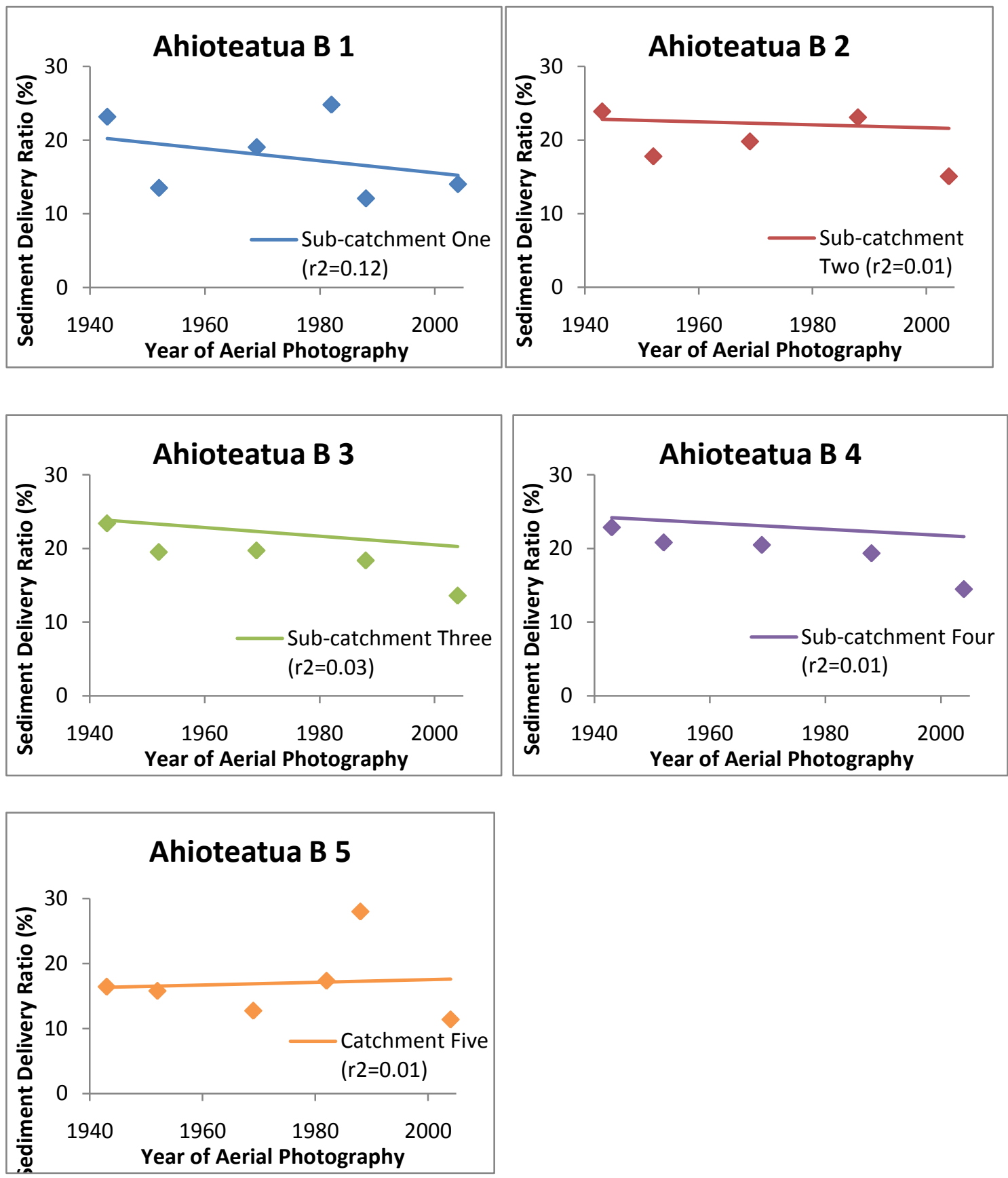


\section{Temporal Trends in Sediment Delivery Ratios \\ Mangakiore Catchment A}
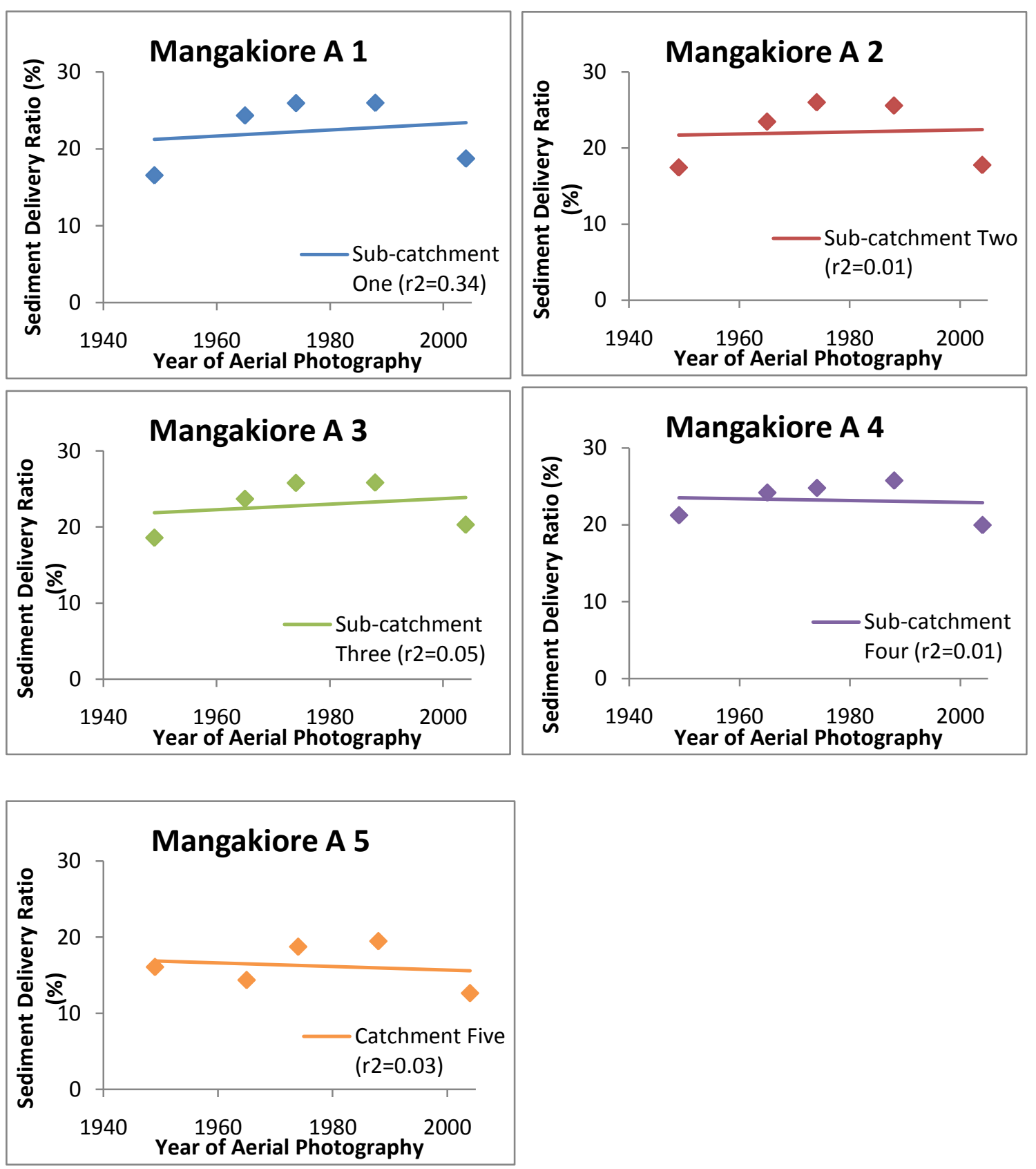


\section{Temporal Trends in Sediment Delivery Ratios Mangakiore Catchment B}
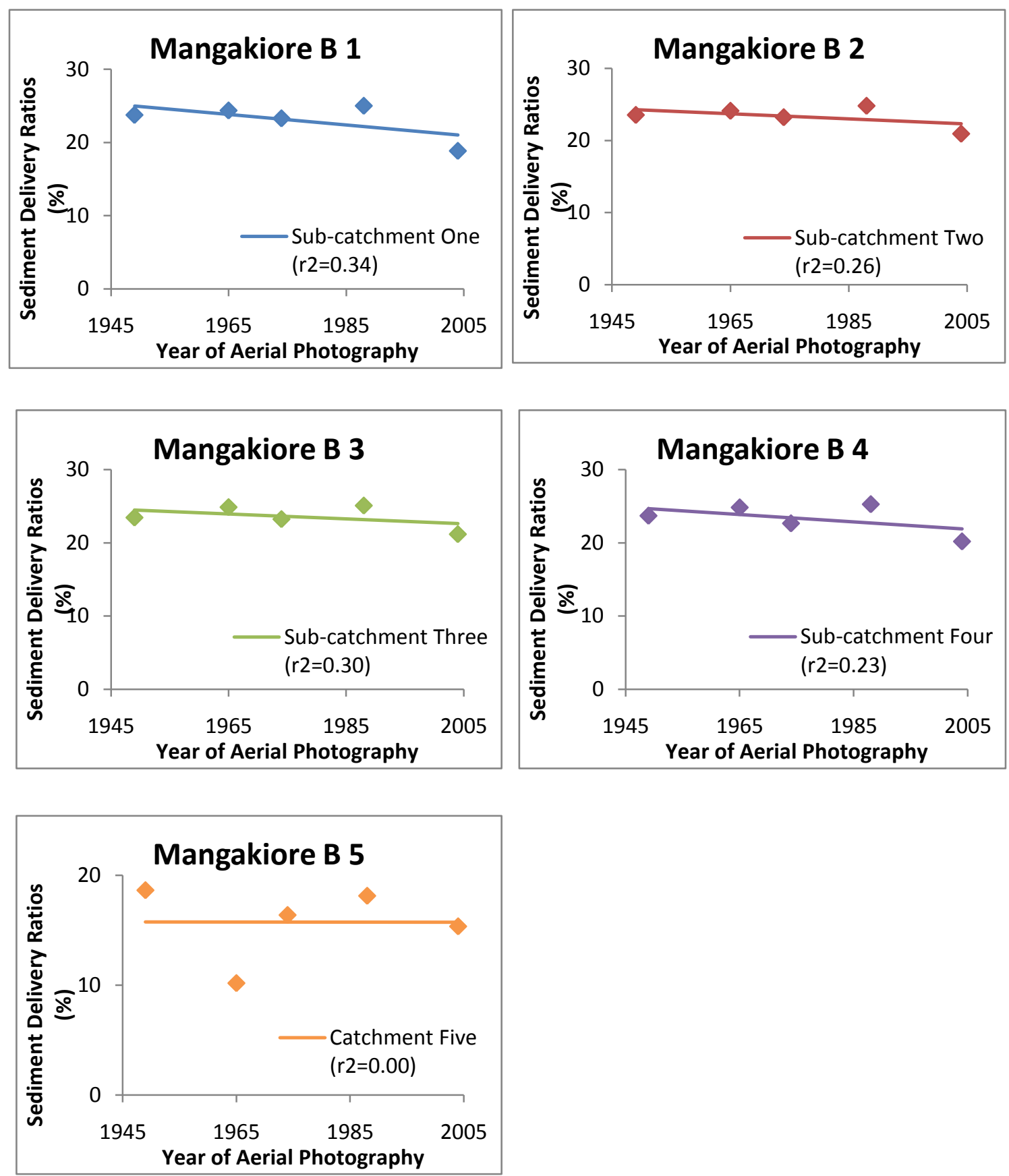
Appendix D: Earthflow Scars

$152 \mid K . E$. Jones

2009 


\section{Earthflow Scars \\ Waimoa Catchment 1952}

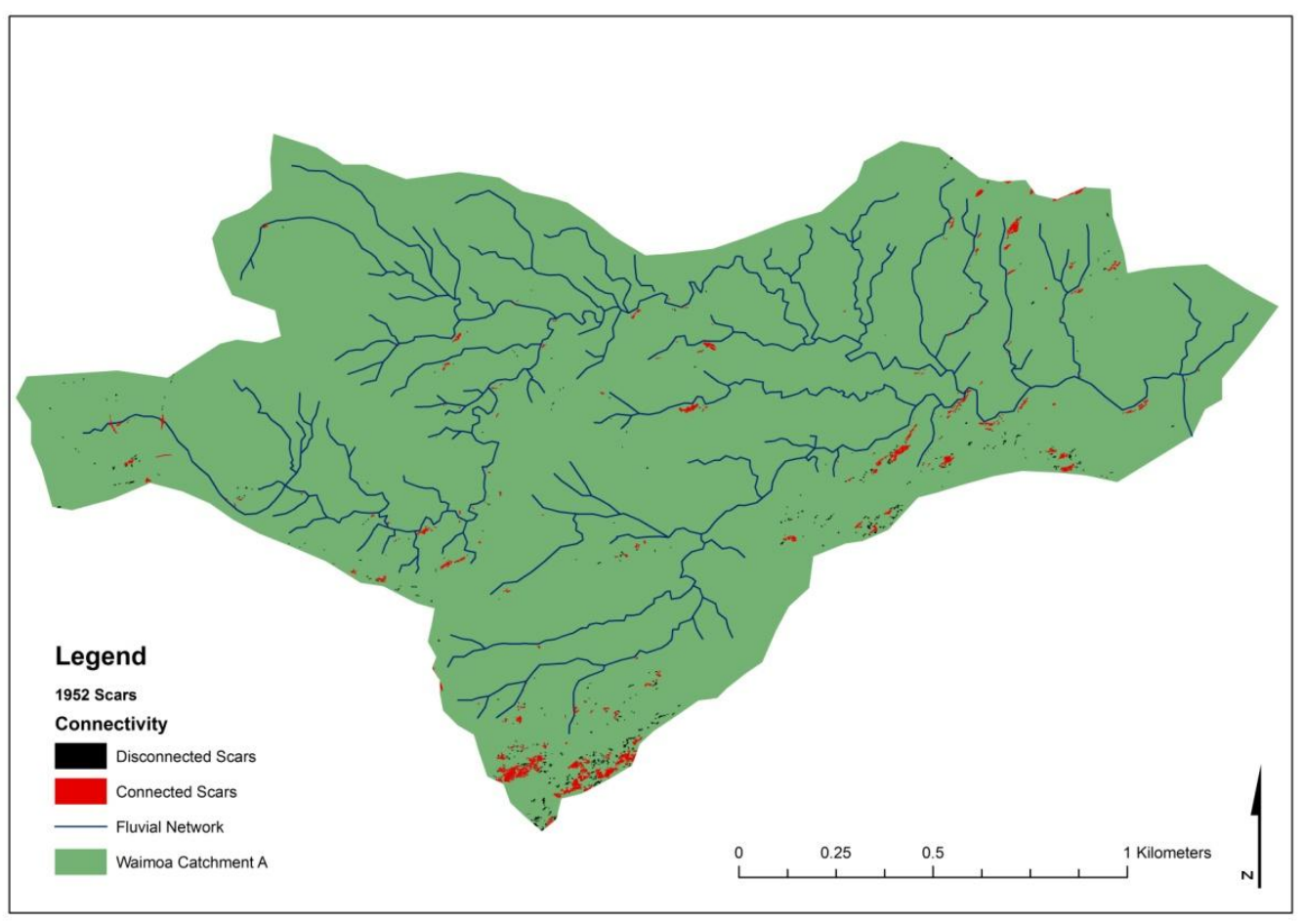

Earthflow Scars

Waimoa Catchment 1965

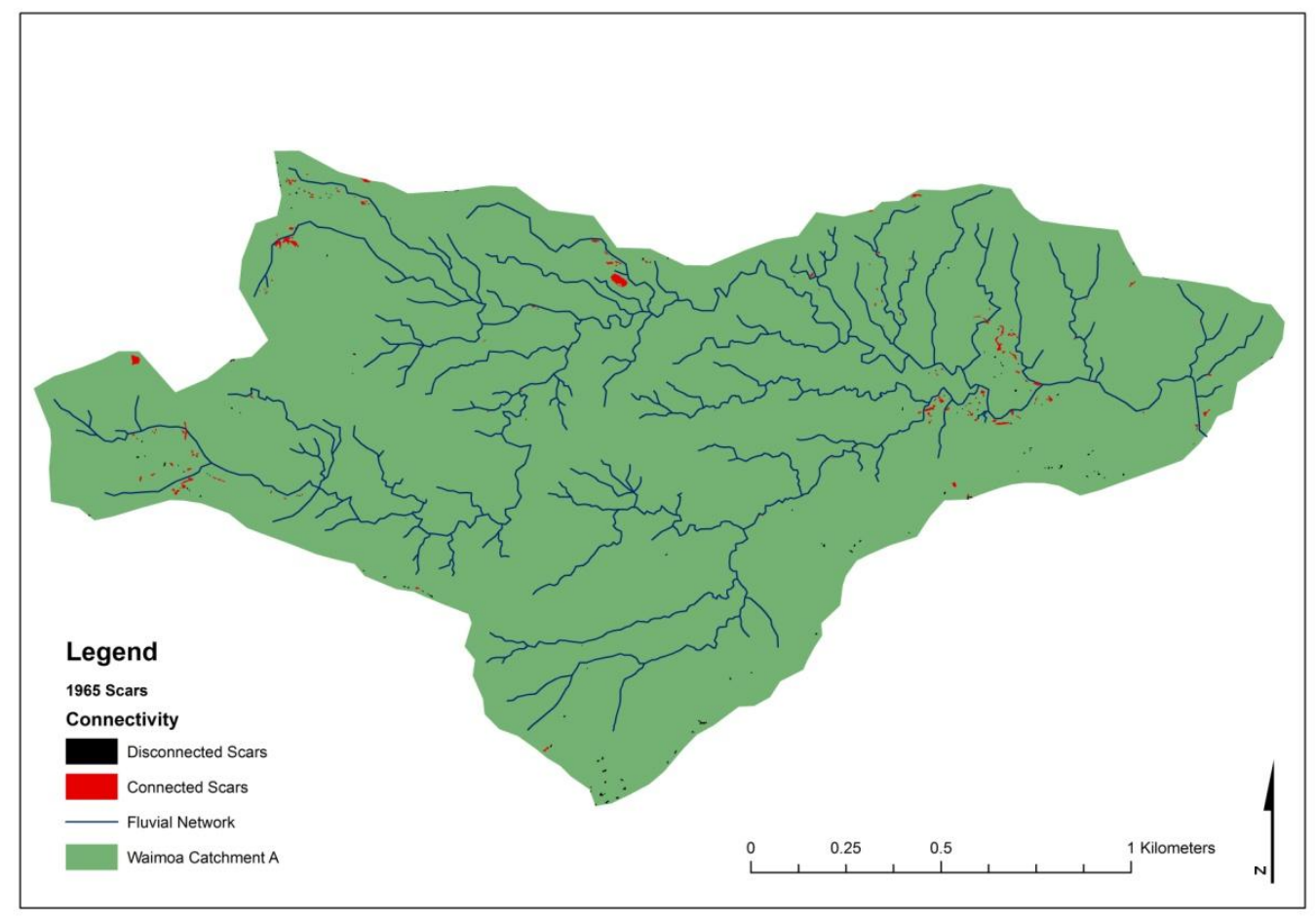

$153 \mid K . E$. Jones 


\section{Earthflow Scars}

\section{Waimoa Catchment 1974}

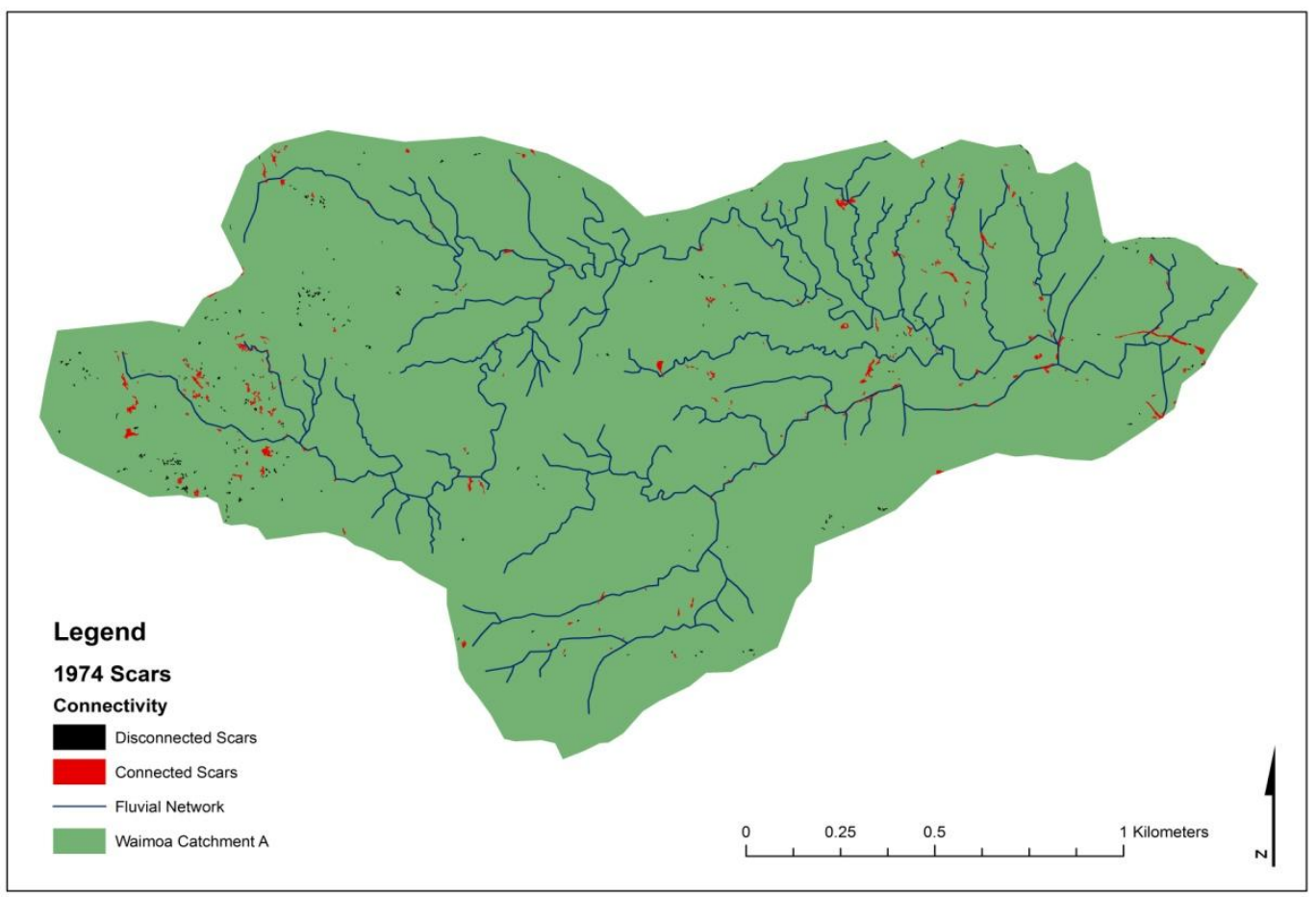

Earthflow Scars

Waimoa Catchment 1980

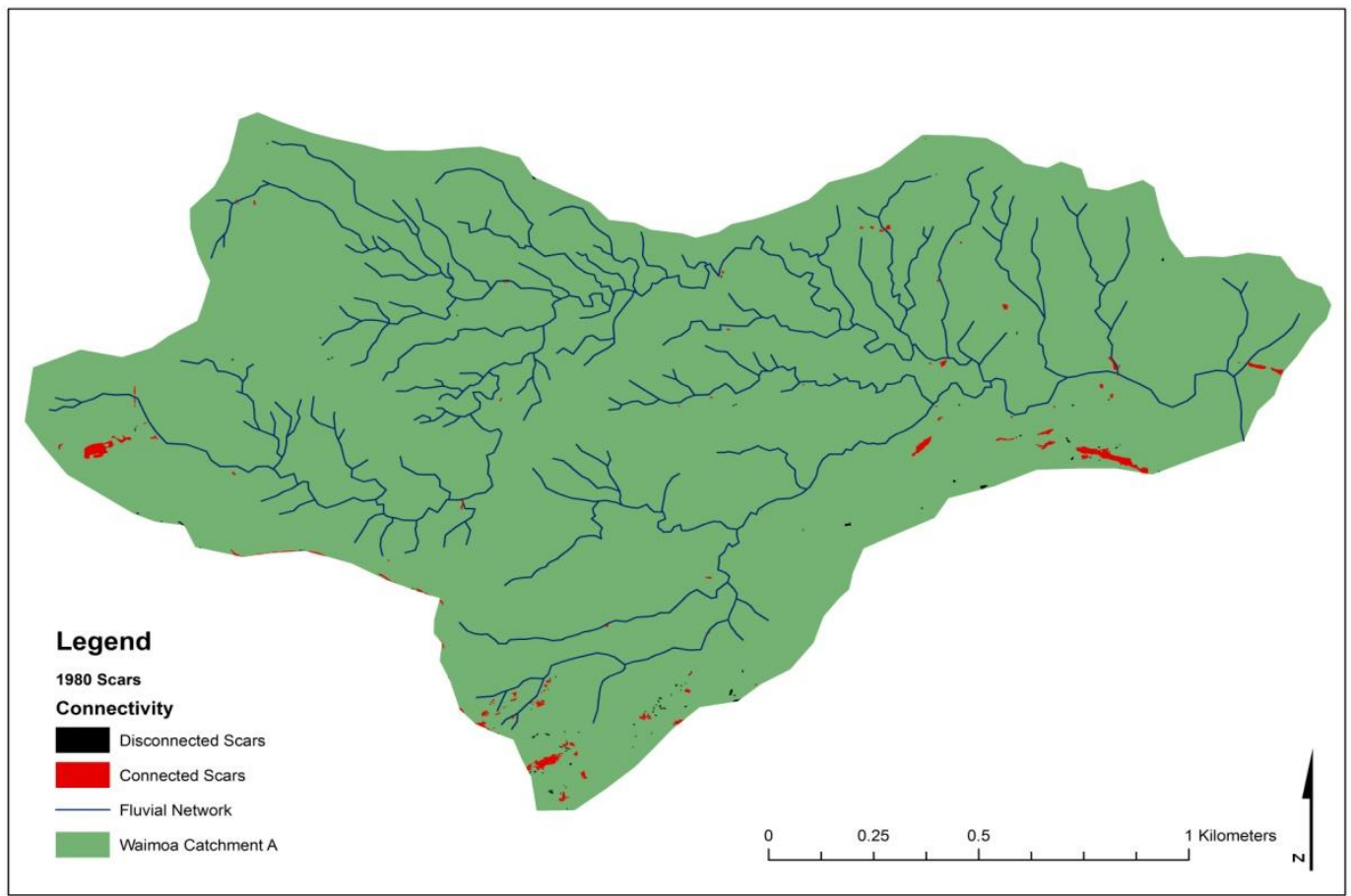




\section{Earthflow Scars}

\section{Waimoa Catchment 1984}

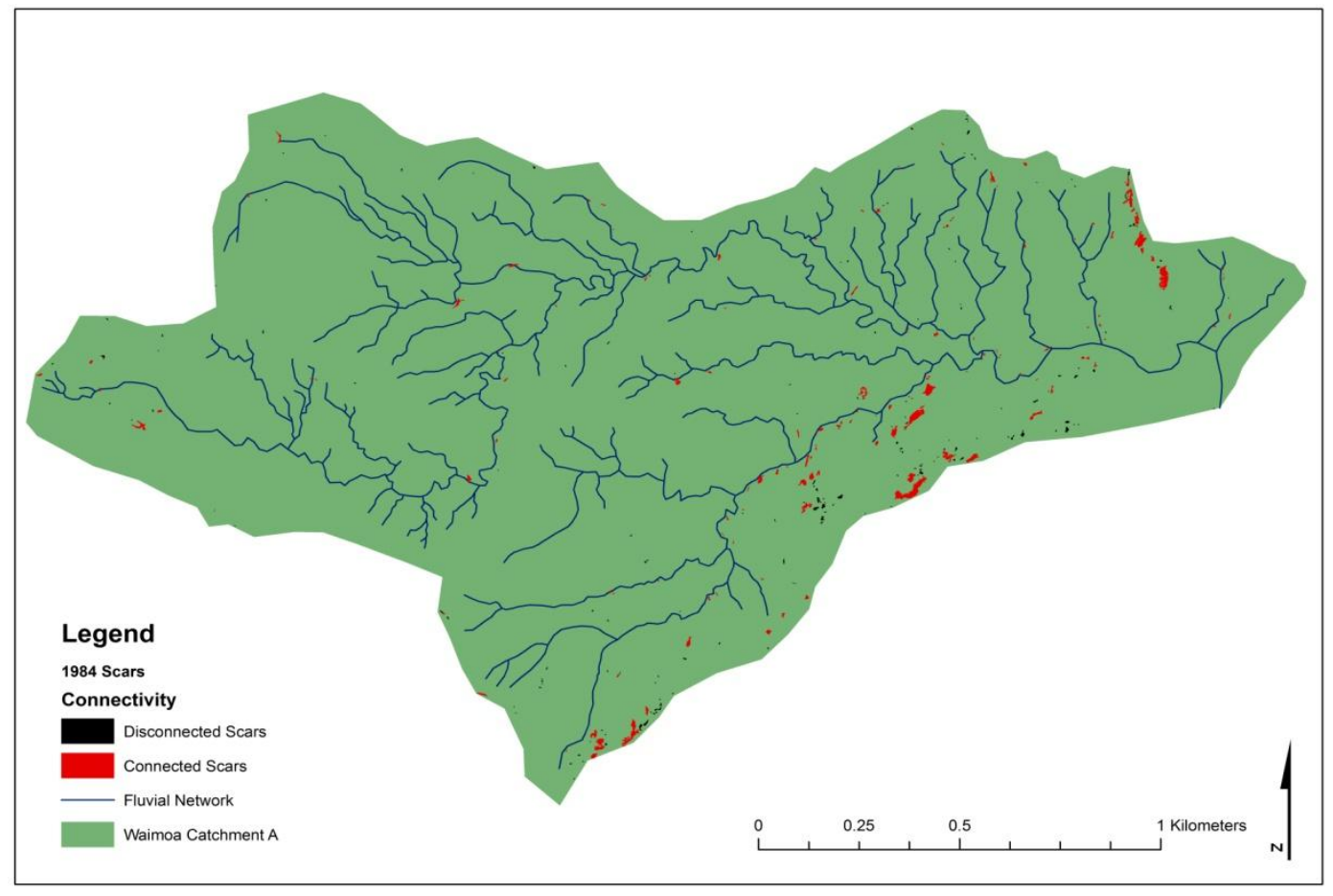

Earthflow Scars

Waimoa Catchment 2004

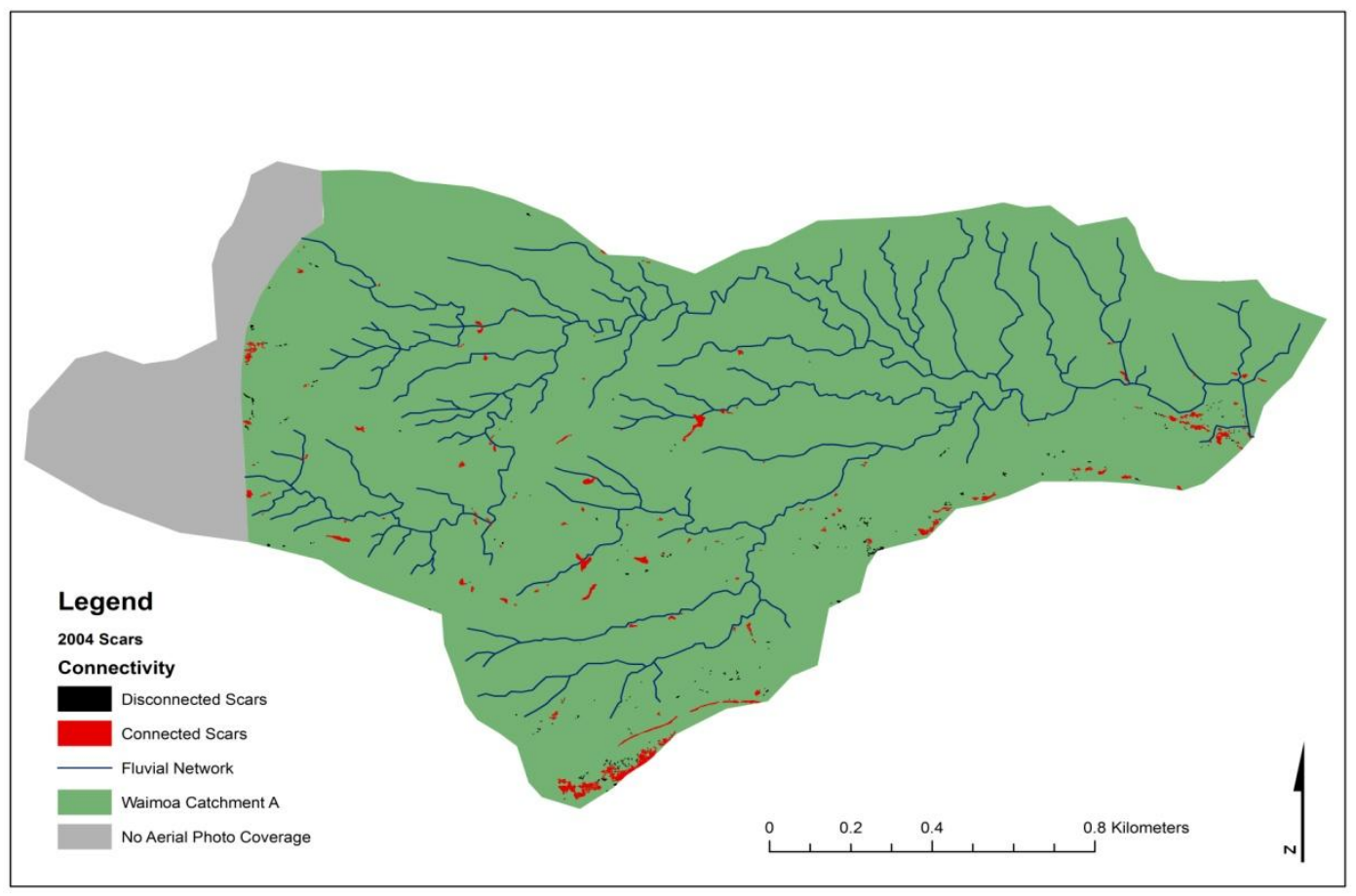




\section{Earthflow Scars \\ Ahioteatua Catchments 1943}
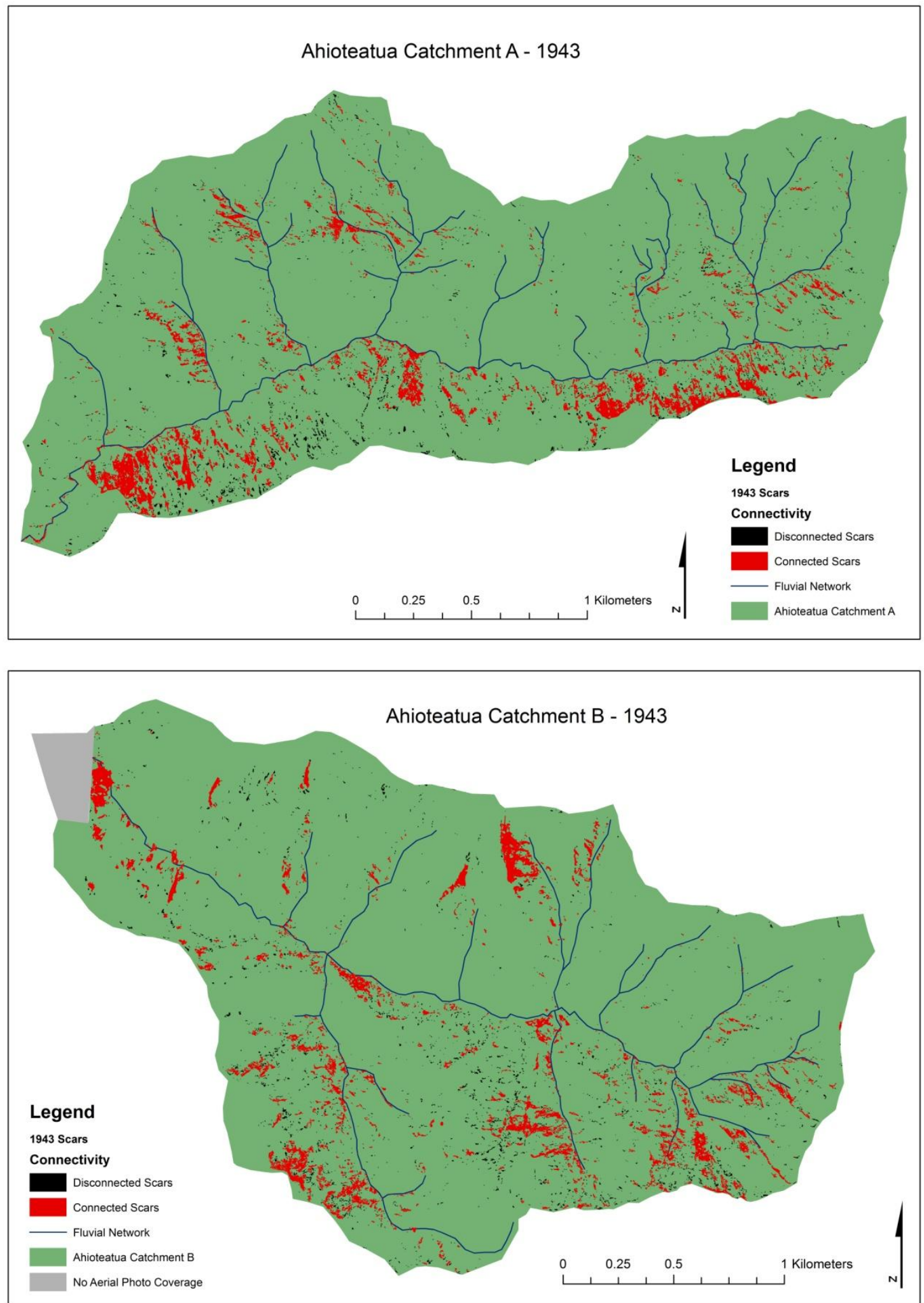


\section{Earthflow Scars \\ Ahioteatua Catchments 1952}
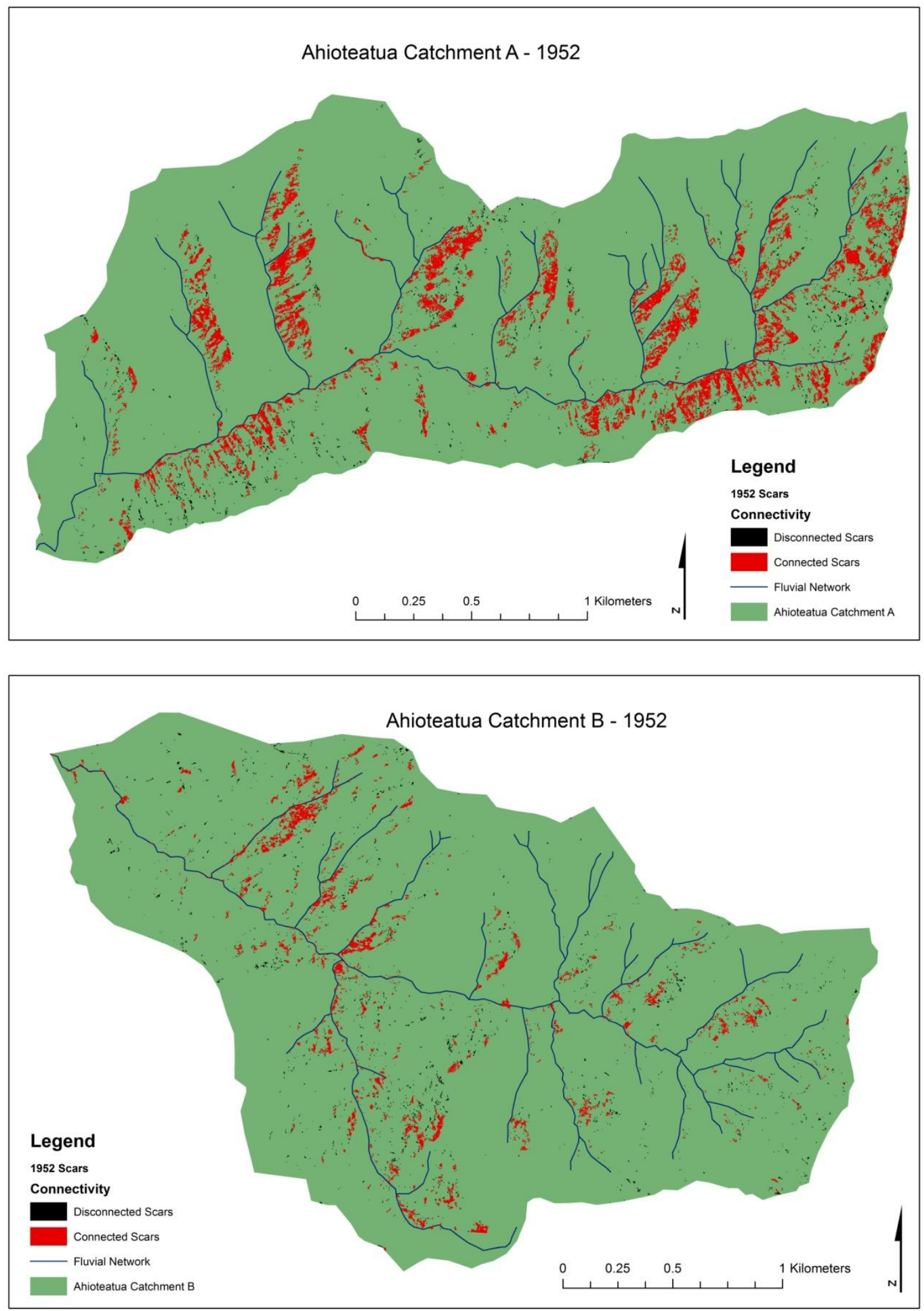


\section{Earthflow Scars \\ Ahioteatua Catchments 1969}
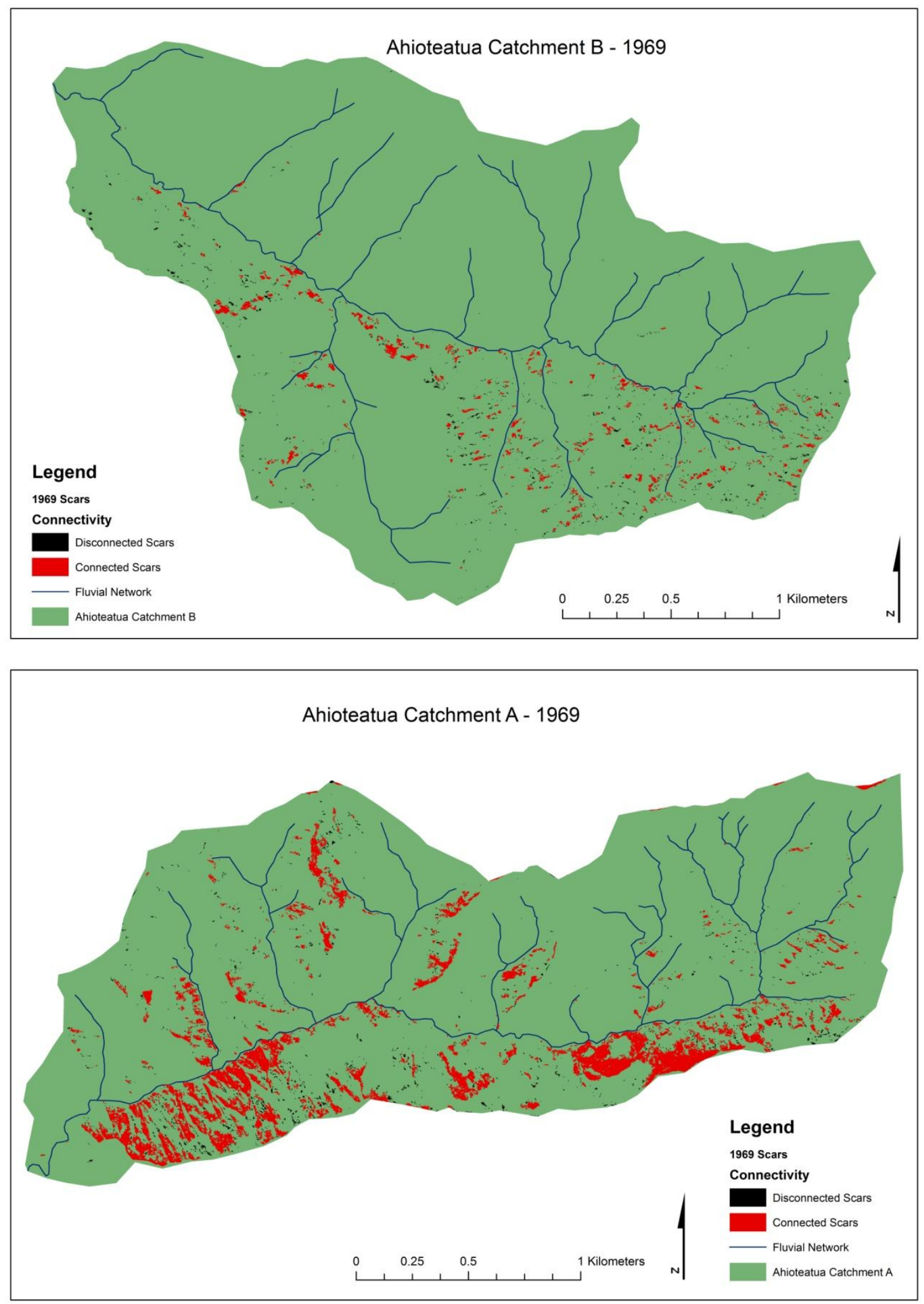


\section{Earthflow Scars \\ Ahioteatua Catchments 1982}
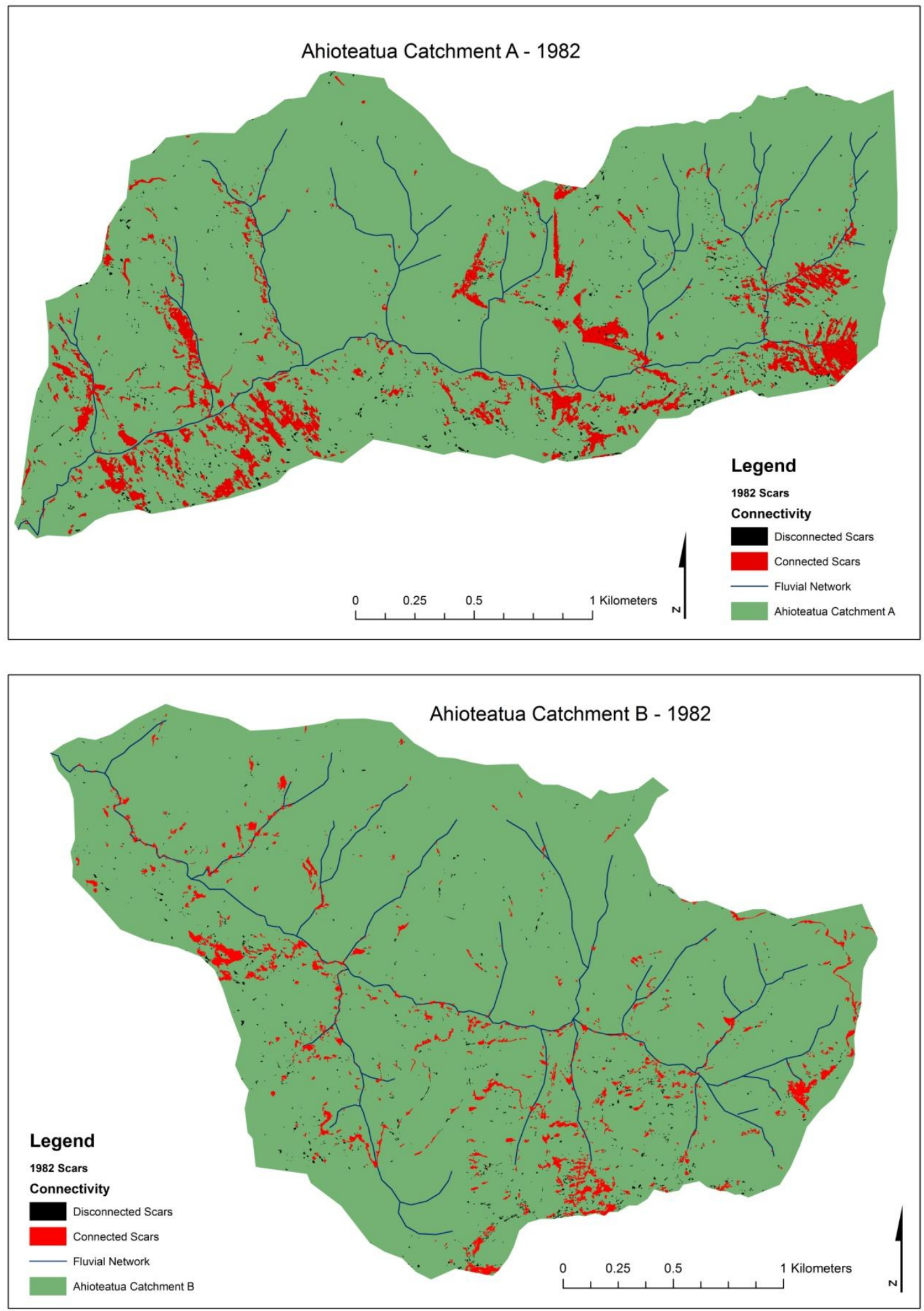


\section{Earthflow Scars \\ Ahioteatua Catchments 1988}
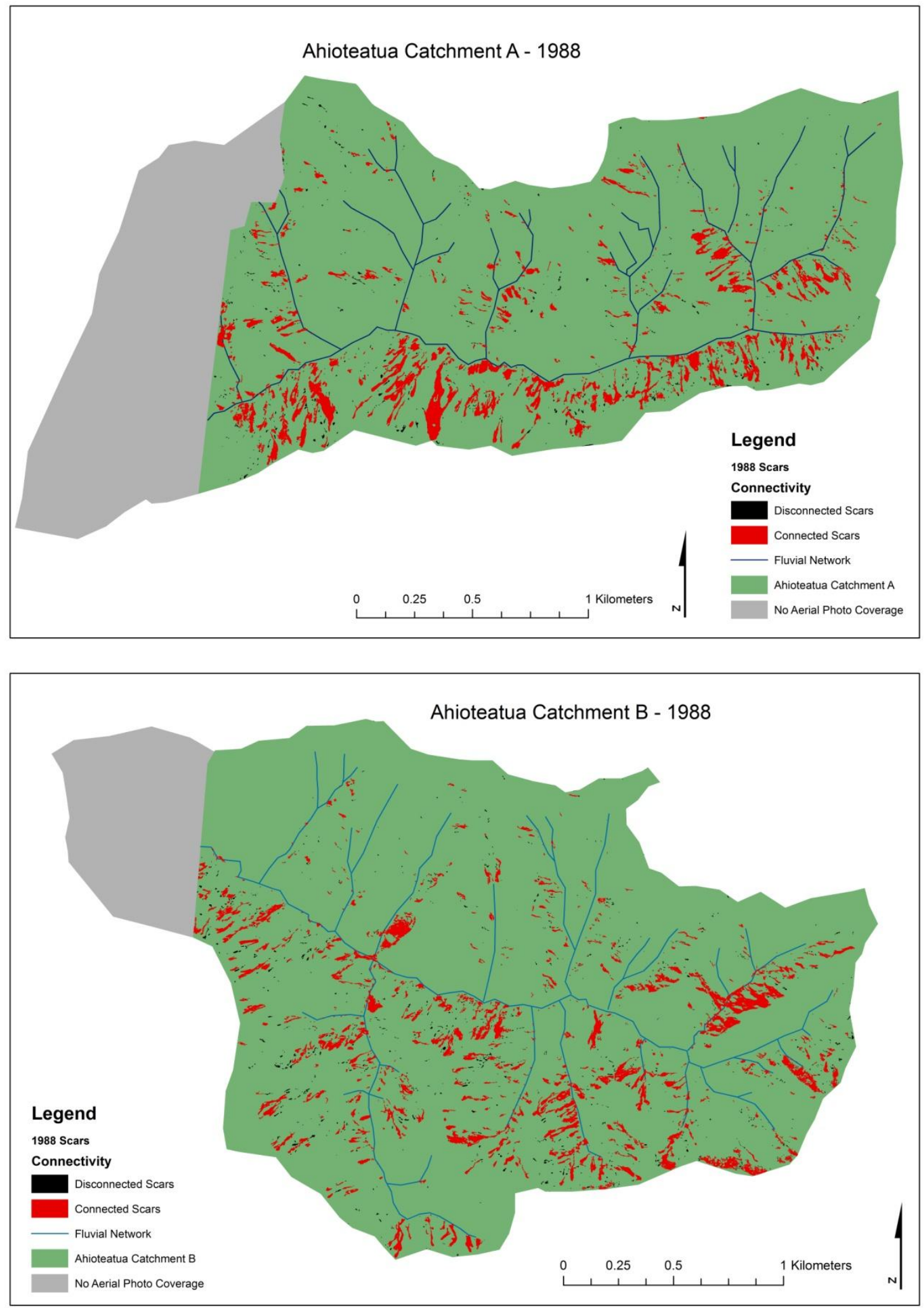


\section{Earthflow Scars \\ Ahioteatua Catchments 2004}
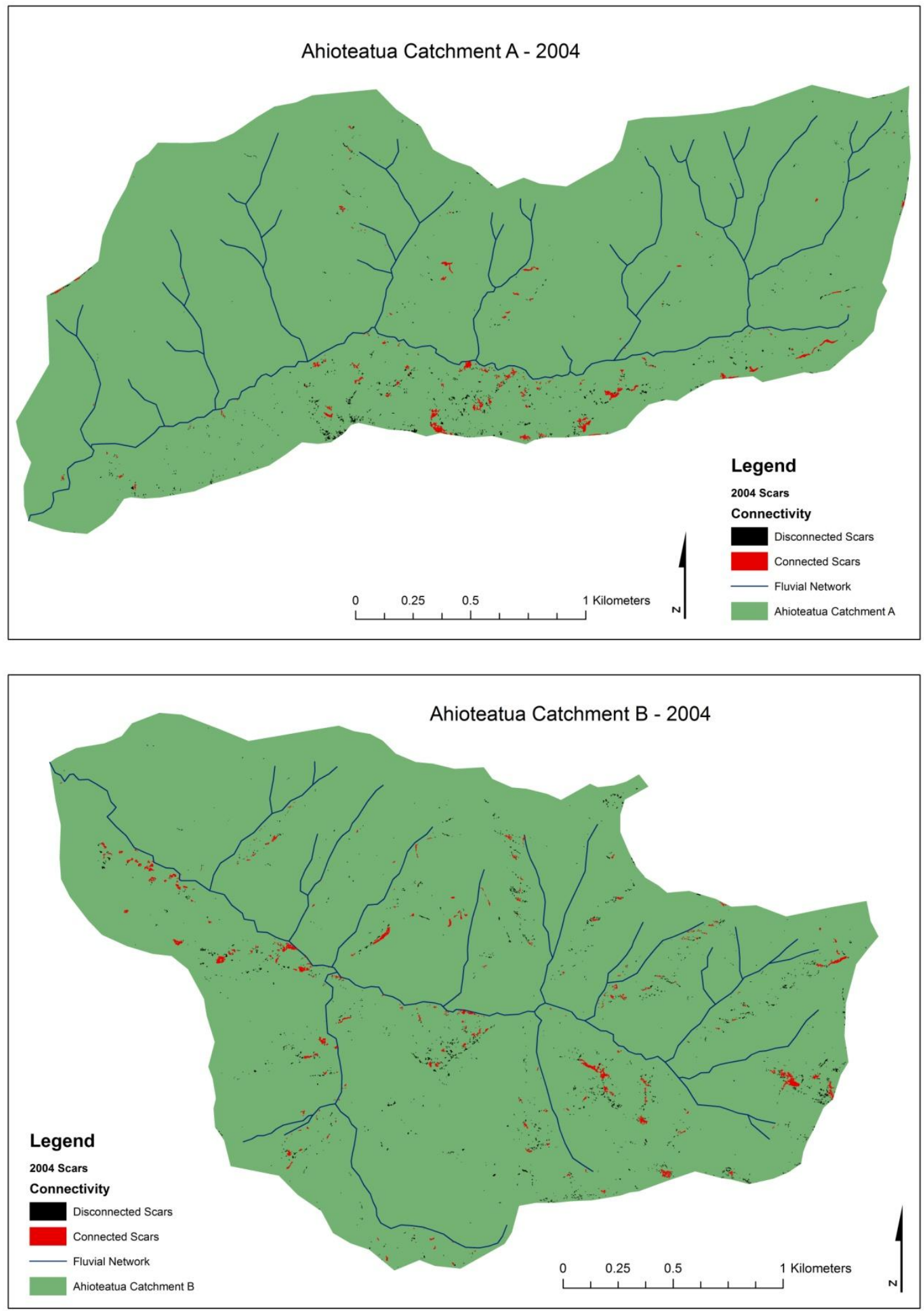


\section{Earthflow Scars}

\section{Mangakiore Catchments 1949}

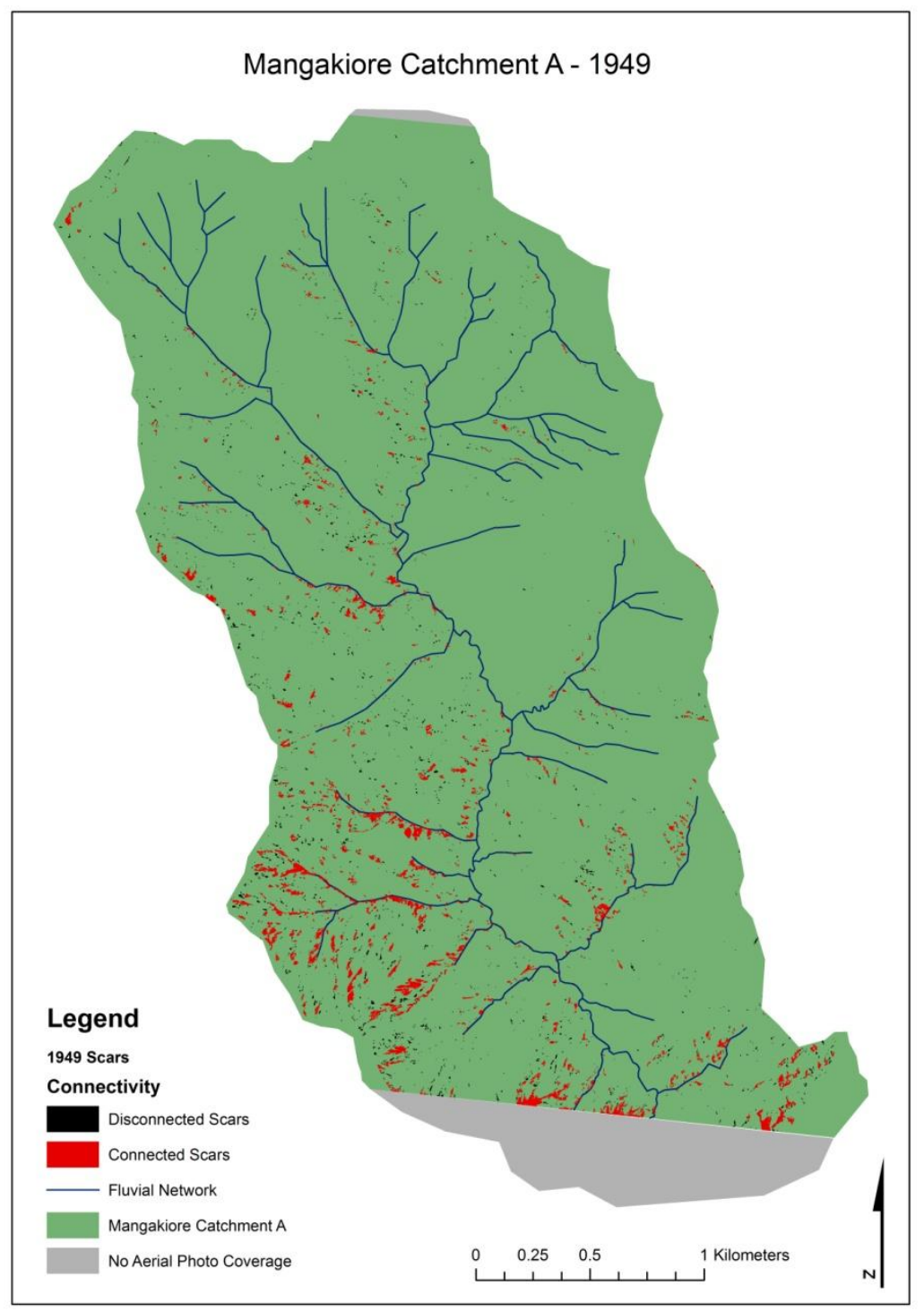

$162 \mid K . E$. Jones

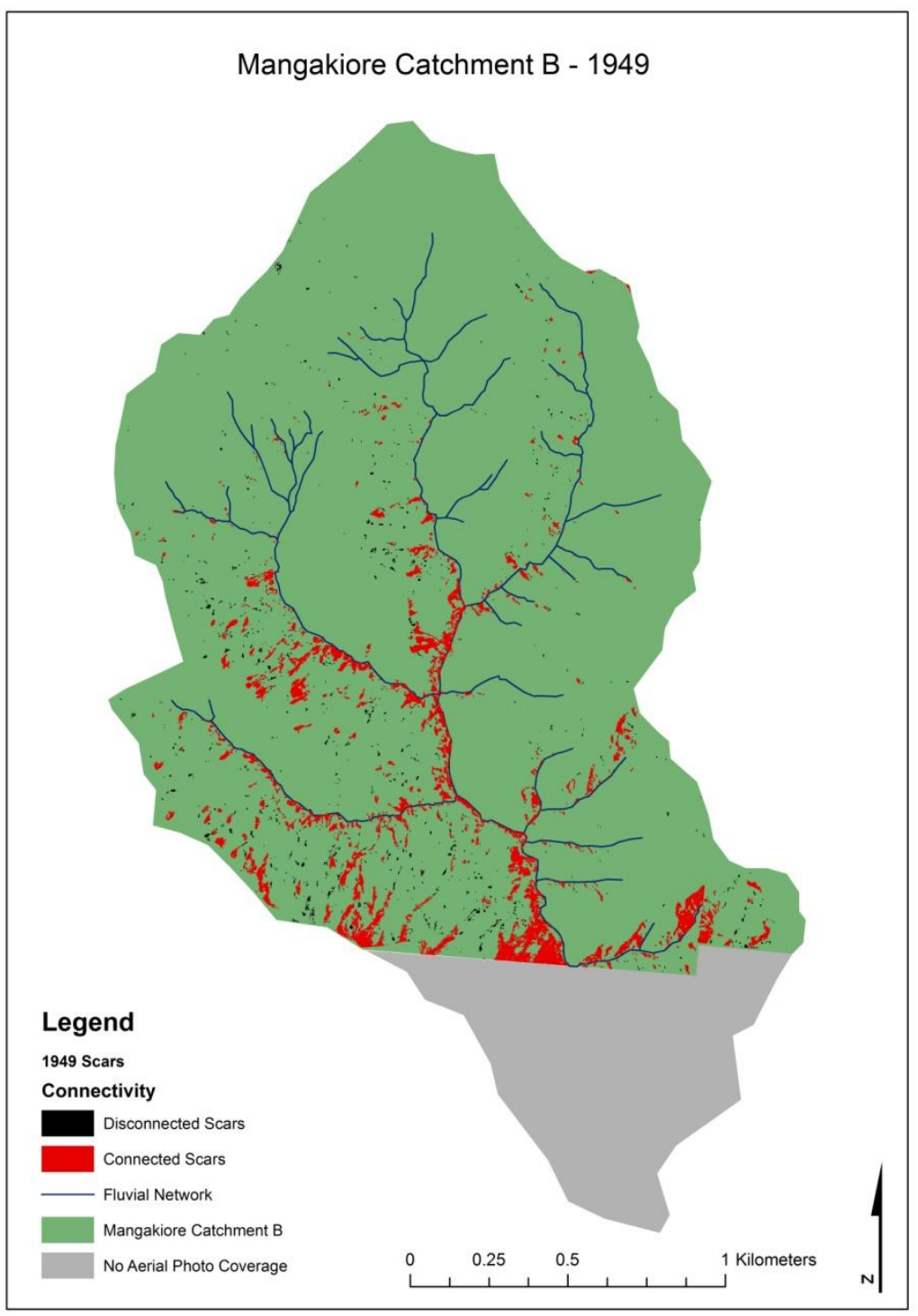

2009 


\section{Earthflow Scars}

\section{Mangakiore Catchments 1965}
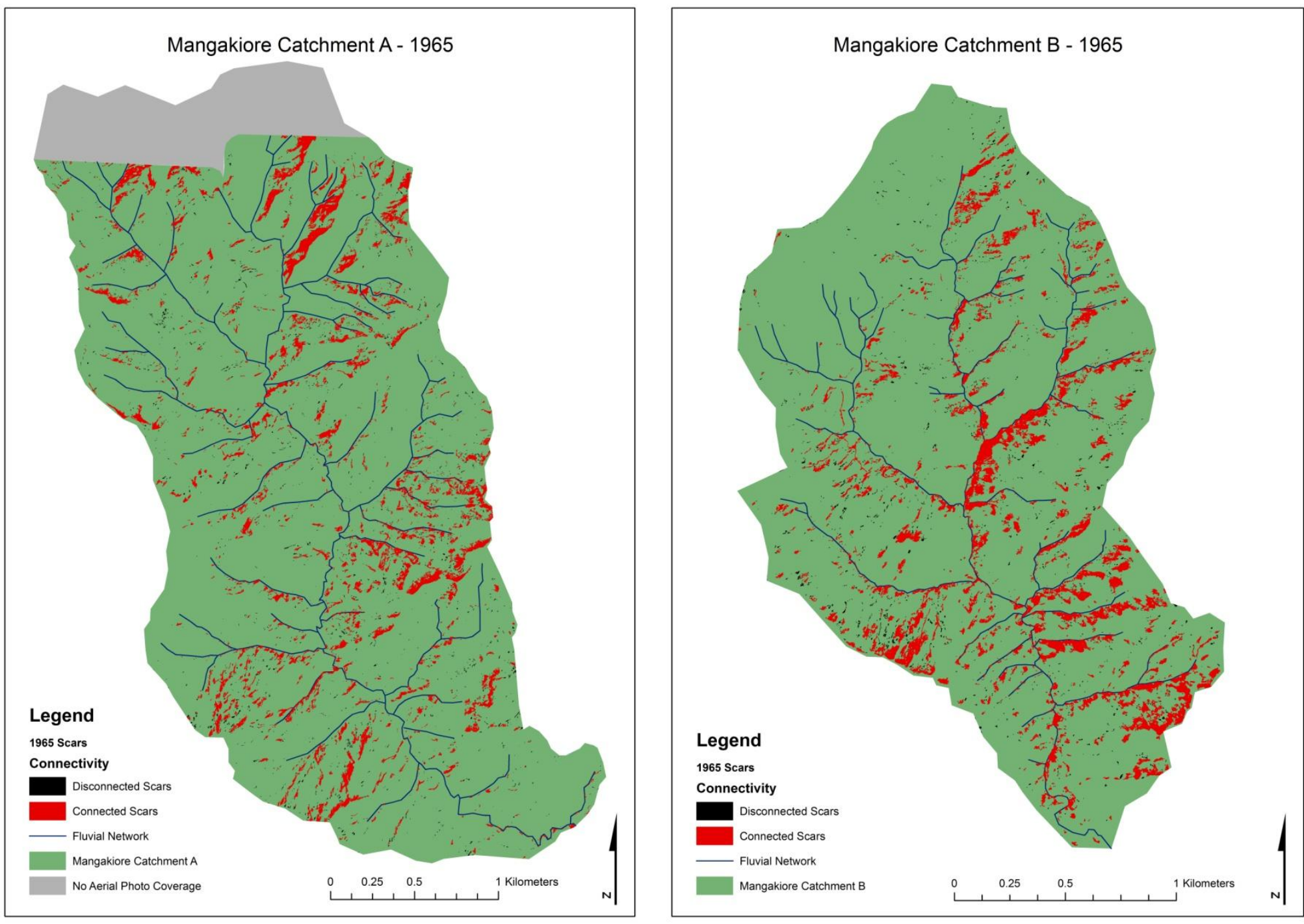

$163 \mid$ K. E. Jones 


\section{Earthflow Scars}

\section{Mangakiore Catchments 1974}
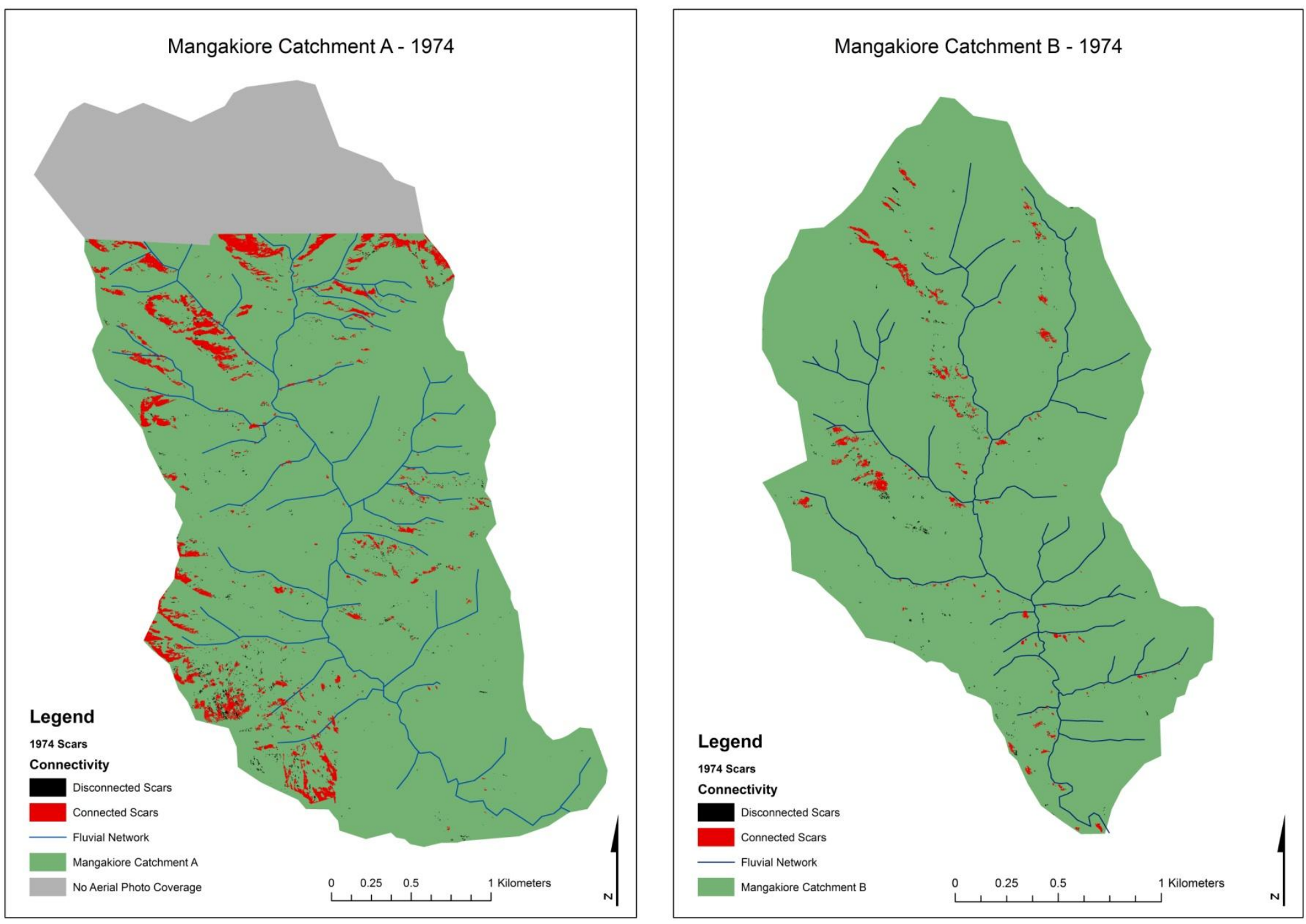

164 | K. E. Jo nes 


\section{Earthflow Scars}

\section{Mangakiore Catchments 1988}
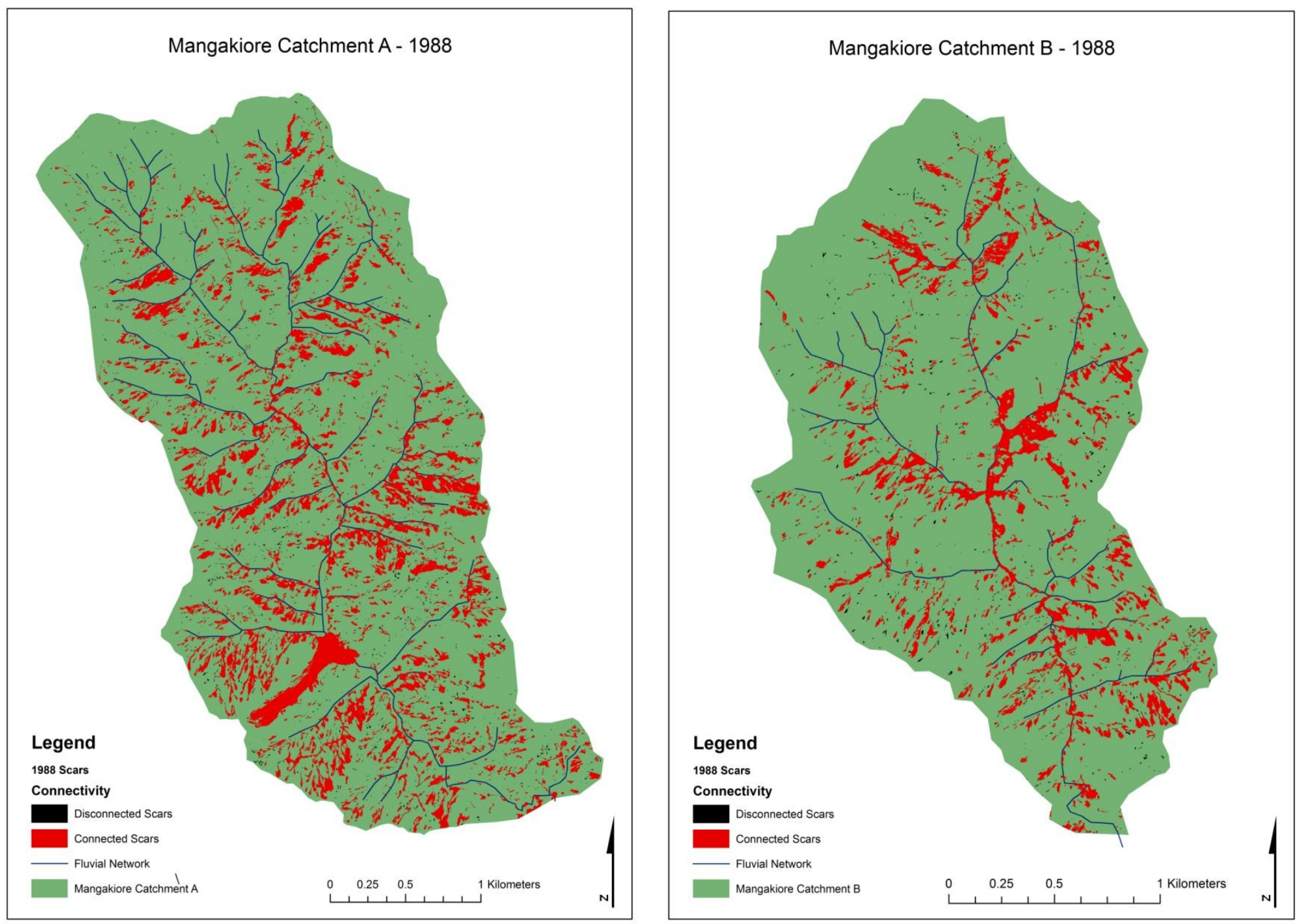


\section{Earthflow Scars}

\section{Mangakiore Catchments 2004}
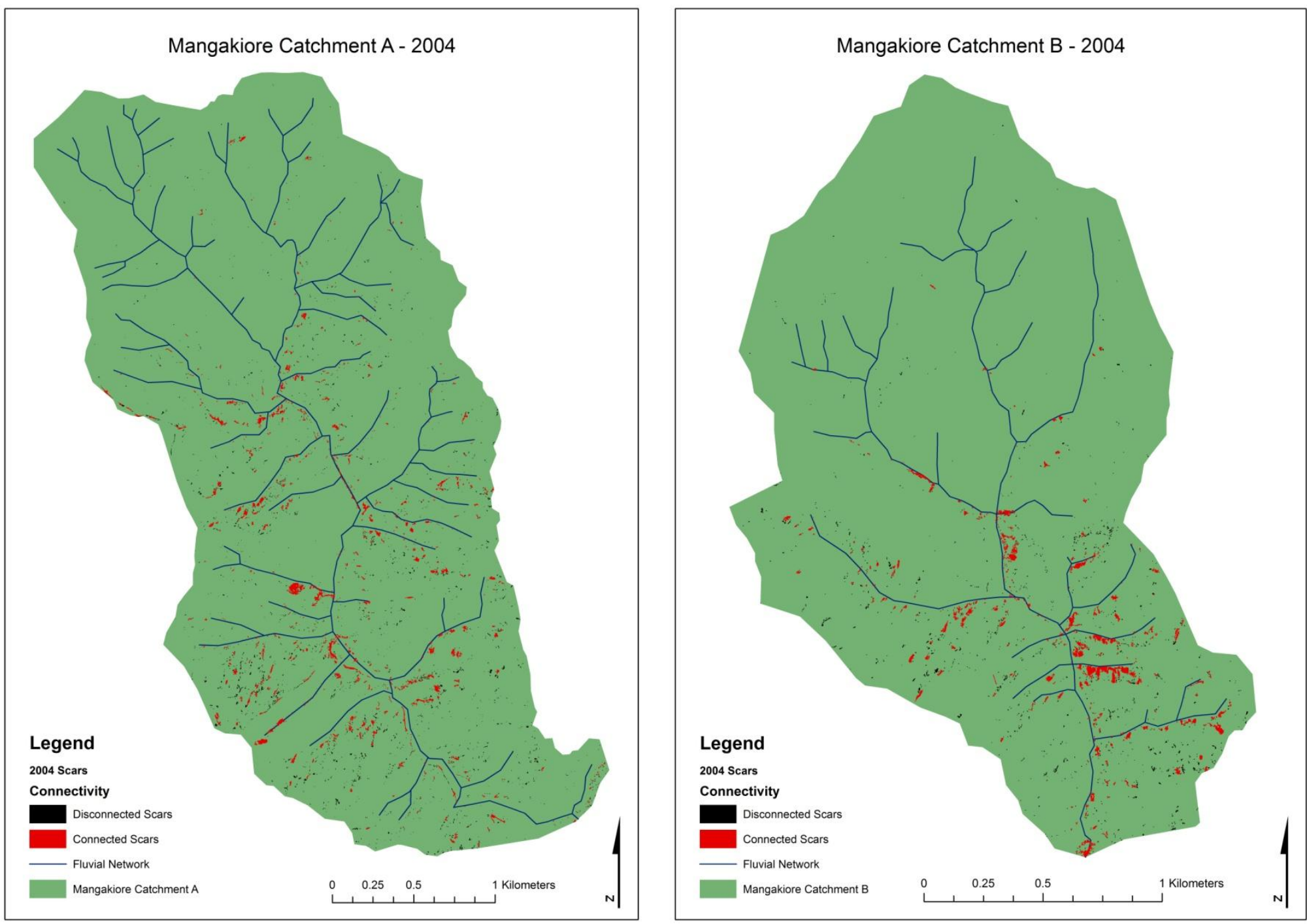


\section{Earthflow Aspect}

Waimoa Catchment

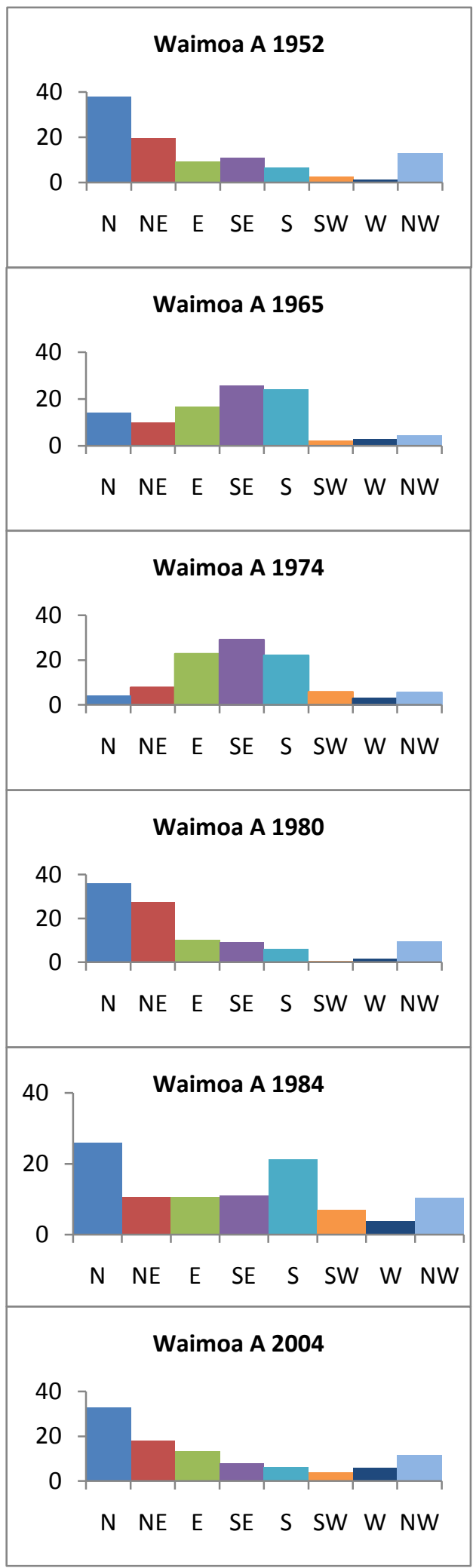




\section{Earthflow Aspect}

\section{Ahioteatua Catchments}

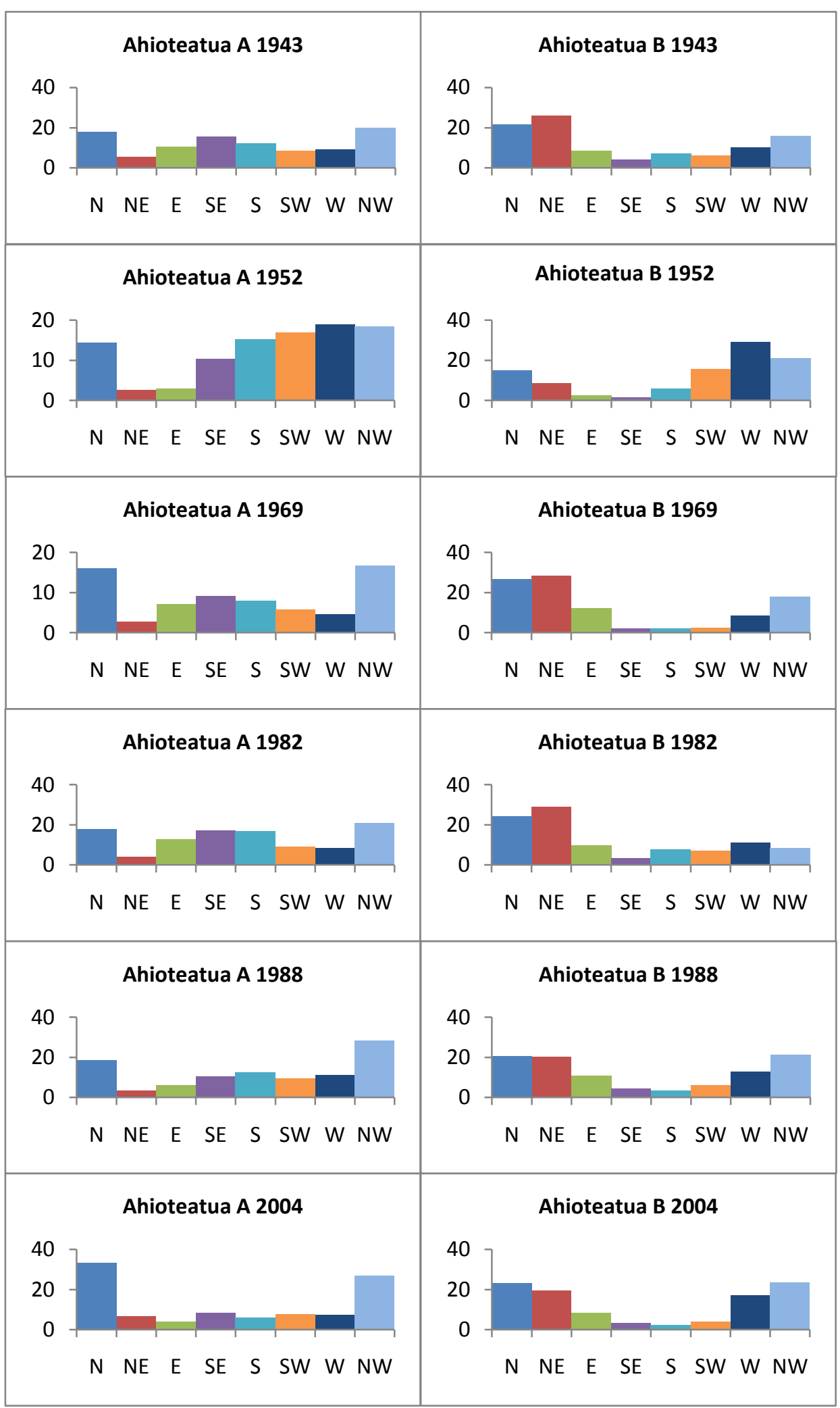




\section{Earthflow Aspect \\ Mangakiore Catchments}

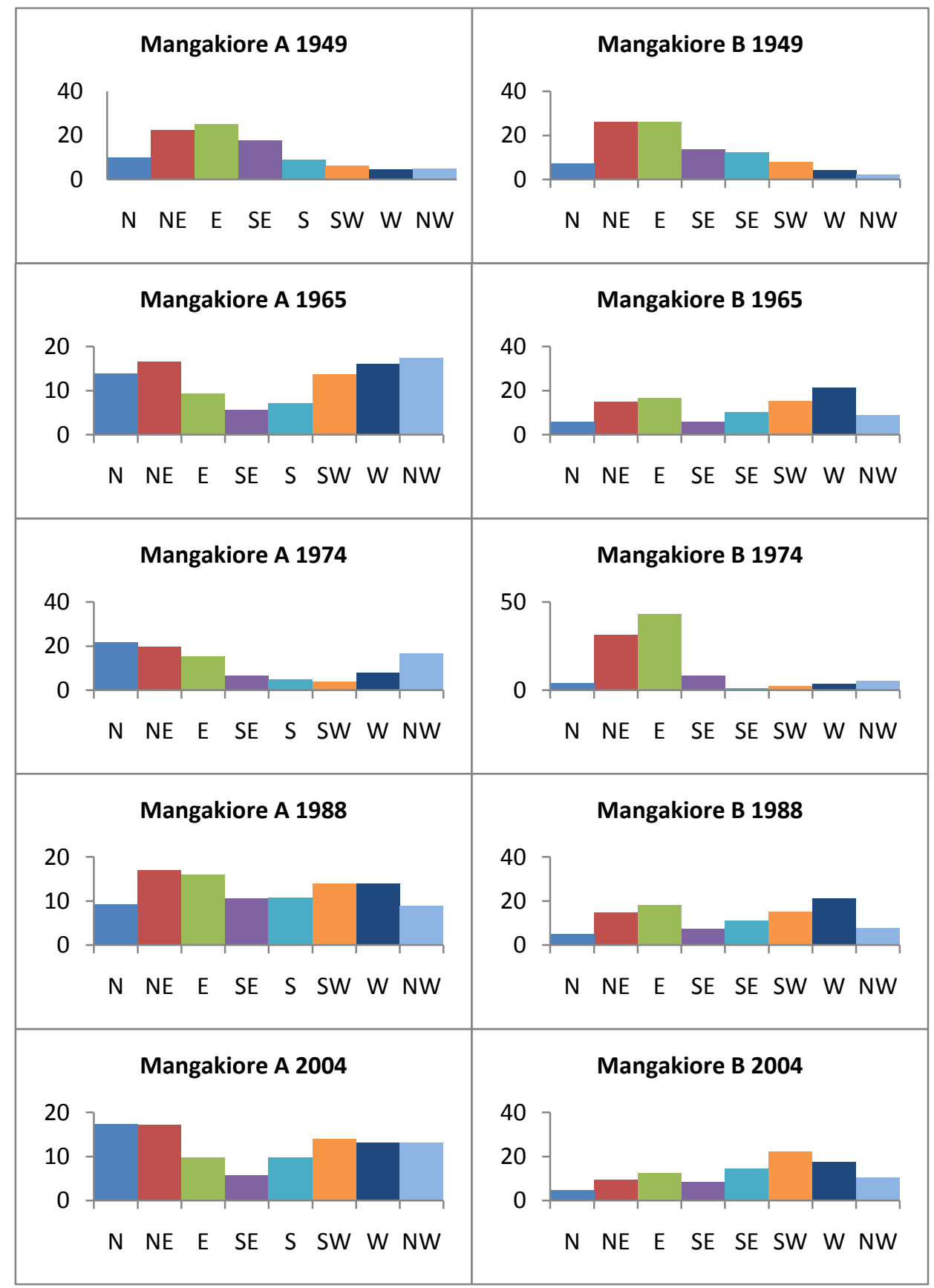




\section{Average Earthflow Scar Properties}

Average Scar Depth from Page et al. (1999):

Waimia: $0.75 \mathrm{~m}$

Ahioteatua: $0.75 \mathrm{~m}$

Mangakiore: $0.76 \mathrm{~m}$

\begin{tabular}{|c|c|c|c|c|}
\hline \multirow[b]{2}{*}{ 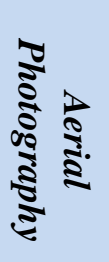 } & \multicolumn{4}{|c|}{ Waimoa Catchment } \\
\hline & 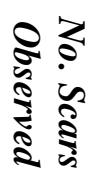 & 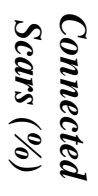 & 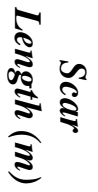 & 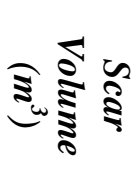 \\
\hline 1952 & 699 & 38 & 33 & 28 \\
\hline 1965 & 289 & 55 & 30 & 24 \\
\hline 1974 & 398 & 51 & 41 & 44 \\
\hline 1980 & 189 & 48 & 48 & 58 \\
\hline 1984 & 323 & 39 & 39 & 39 \\
\hline 2004 & 371 & 38 & 42 & 46 \\
\hline
\end{tabular}

\begin{tabular}{|c|c|c|c|c|c|c|c|c|}
\hline \multirow[b]{2}{*}{ 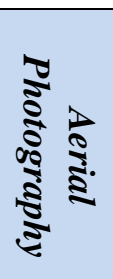 } & \multicolumn{4}{|c|}{ Ahioteatua Catchment A } & \multicolumn{4}{|c|}{ Ahioteatua Catchment B } \\
\hline & 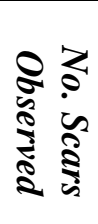 & 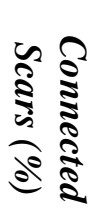 & 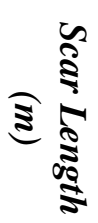 & 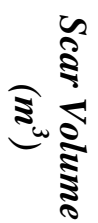 & 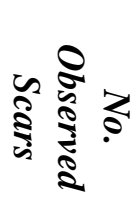 & 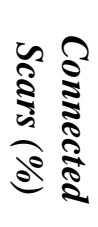 & 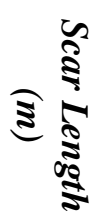 & 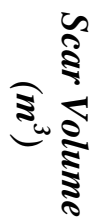 \\
\hline 1943 & 3638 & 33 & 46 & 53 & 3774 & 30 & 48 & 59 \\
\hline 1952 & 3225 & 31 & 57 & 82 & 2927 & 30 & 38 & 38 \\
\hline 1969 & 2085 & 26 & 71 & 125 & 2447 & 27 & 34 & 30 \\
\hline 1982 & 2865 & 37 & 62 & 96 & 2195 & 38 & 53 & 71 \\
\hline 1988 & 1913 & 43 & 65 & 104 & 1917 & 31 & 69 & 118 \\
\hline 2004 & 1048 & 14 & 33 & 32 & 2085 & 15 & 35 & 29 \\
\hline
\end{tabular}

\begin{tabular}{|c|c|c|c|c|c|c|c|c|}
\hline \multirow[b]{2}{*}{ 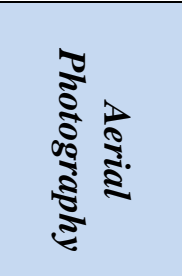 } & \multicolumn{4}{|c|}{ Mangakiore $A$} & \multicolumn{4}{|c|}{ Mangakiore $B$} \\
\hline & 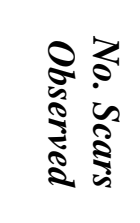 & 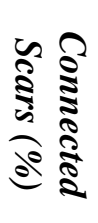 & 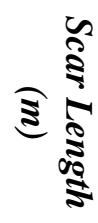 & 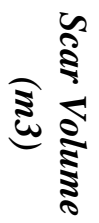 & 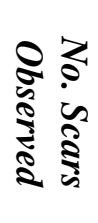 & 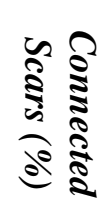 & 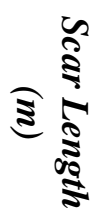 & $\widehat{\underbrace{}}$ \\
\hline 1949 & 5390 & 31 & 48 & 44 & 1670 & 44 & 57 & 48 \\
\hline 1965 & 7547 & 42 & 61 & 93 & 2926 & 42 & 63 & 61 \\
\hline 1974 & 4078 & 22 & 61 & 94 & 842 & 26 & 45 & 61 \\
\hline 1701988 E. & J 067944 & 45 & 80 & 157 & 1937 & 48 & 7520 & 0980 \\
\hline 2004 & 4804 & 23 & 35 & 31 & 1476 & 28 & 30 & 35 \\
\hline
\end{tabular}




\section{Appendix E: Storm History of the Waipaoa Catchment}




\section{Rainfall History}

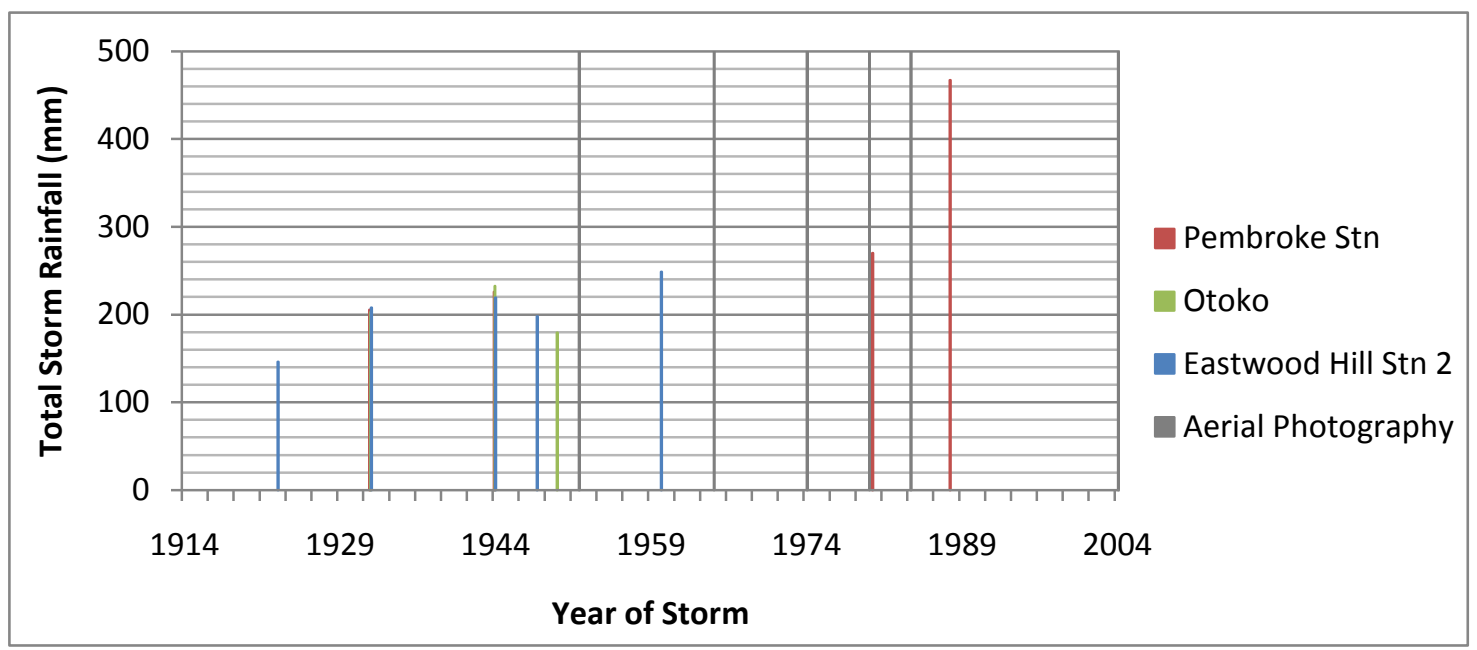

Suggested storm magnitude - frequency history for the Wharekopae field site from 2/4/1913 t15/4/2004 the date of the last aerial photograph used for the Waimoa catchments. The Pembroke station rain gauge was the closest to the Waimoa catchments however this gauge was only started on 2/1/1979. Therefore the possible storm history can be extended back using the both the Otoko and Eastwood Hill 2 station which date from 2/4/1931 and 2/4/1923 respectively but are located to the NE and SE of the Waimoa catchments.

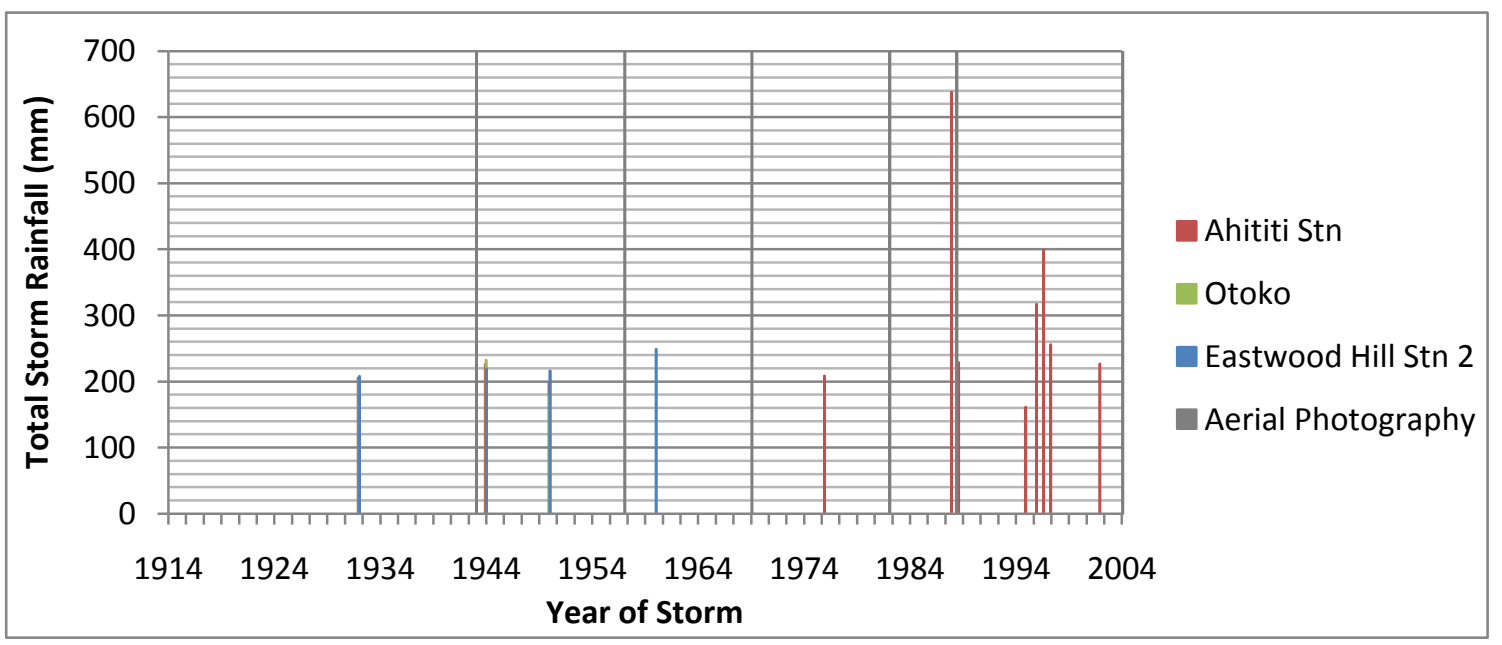

Suggested storm magnitude - frequency history for the Waihora field site from 2/4/1913 to 15/4/2004 the date of the last aerial photograph used for the Ahioteatui catchments. The Ahititi station rain gauge was the closest to the Ahioteatui catchments however this gauge was only started on 2/11/1973. Therefore the possible storm history can be 
extended back using the both the Otoko and Eastwood Hill 2 station which date from 2/4/1931 and 2/4/1923 respectively but are located to the north-west and south-west of the Ahioteatui catchments.

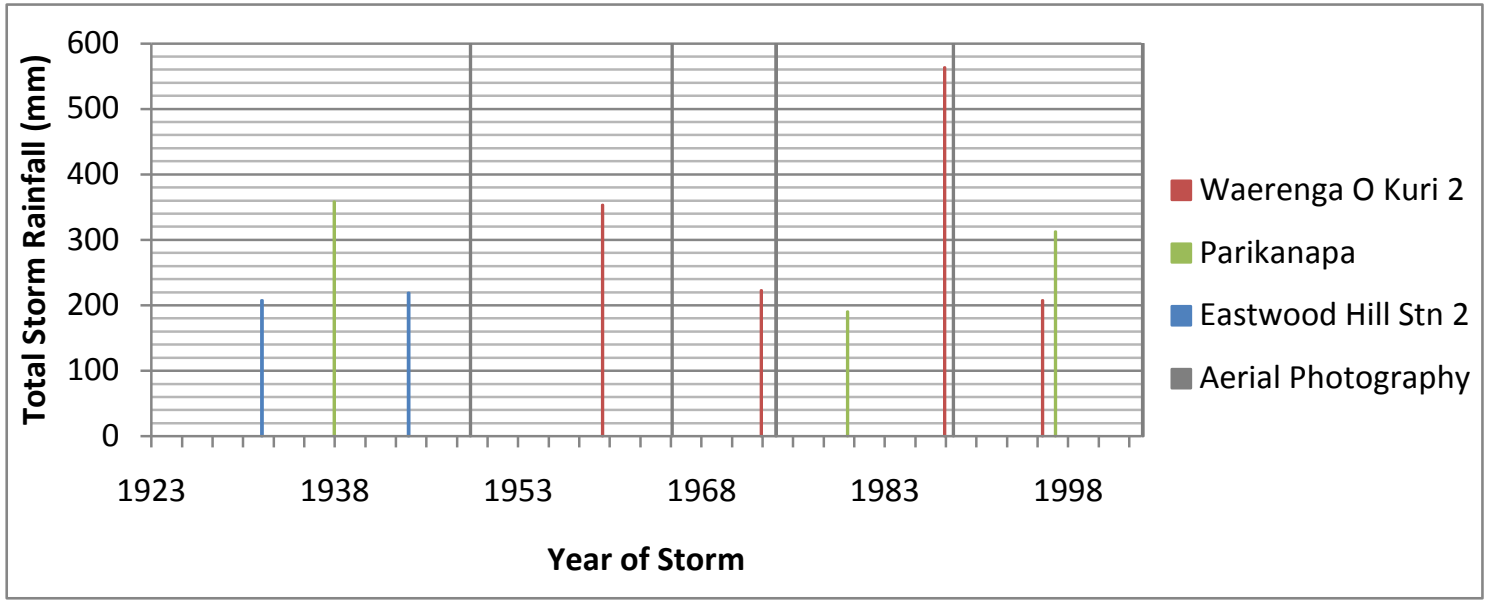

Suggested storm magnitude - frequency history for the Te Arai field site from 2/4/1923 to 10/4/2004 the date of the last aerial photograph used for the Mangakiore catchments. The Waerenga $O$ Kuri 2 rain gauge was the closest to the Mangakiore catchment however this gauge and this started on 2/10/1948 which only just predates the first aerial photo used taken on 2/3/1949. However the possible storm history can be extended using the Parikanapa rain gauge which is the nearest rain gauge to the east with a longer history as it was started on 2/4/1937 and the longer Eastwood Hill Stn 2 to the north. Gaps in the Waerenga $O$ Kuir 2 rain gauge are filled by the Parikanapa data. 